\title{
De Limburgse arbeidsmarkt 1998-2002
}

Citation for published version (APA):

van Eijs, P. W. L. J., Delmee, J., Diephuis, B. J., de Grip, A., Nekkers, G. J. A., \& van Camp, H. (1999). De Limburgse arbeidsmarkt 1998-2002. Researchcentrum voor Onderwijs en Arbeidsmarkt, Faculteit der Economische Wetenschappen. ROA Reports No. 1 https://doi.org/10.26481/umarep.1999001

Document status and date:

Published: 01/01/1999

DOI:

10.26481/umarep.1999001

Document Version:

Publisher's PDF, also known as Version of record

\section{Please check the document version of this publication:}

- A submitted manuscript is the version of the article upon submission and before peer-review. There can be important differences between the submitted version and the official published version of record.

People interested in the research are advised to contact the author for the final version of the publication, or visit the DOI to the publisher's website.

- The final author version and the galley proof are versions of the publication after peer review.

- The final published version features the final layout of the paper including the volume, issue and page numbers.

Link to publication

\footnotetext{
General rights rights.

- You may freely distribute the URL identifying the publication in the public portal. please follow below link for the End User Agreement:

www.umlib.nl/taverne-license

Take down policy

If you believe that this document breaches copyright please contact us at:

repository@maastrichtuniversity.nl

providing details and we will investigate your claim.
}

Copyright and moral rights for the publications made accessible in the public portal are retained by the authors and/or other copyright owners and it is a condition of accessing publications that users recognise and abide by the legal requirements associated with these

- Users may download and print one copy of any publication from the public portal for the purpose of private study or research.

- You may not further distribute the material or use it for any profit-making activity or commercial gain

If the publication is distributed under the terms of Article $25 \mathrm{fa}$ of the Dutch Copyright Act, indicated by the "Taverne" license above, 


\section{De Limburgse arbeidsmarkt 1998-2002}

ROA-R-1999/1

P. van Eijs

J. Delmee

B. Diephuis

A. de Grip

G. Nekkers

H. van Camp (ETIL)

\section{Researchcentrum voor Onderwijs en Arbeidsmarkt}

Faculteit der Economische Wetenschappen en Bedrijfskunde Universiteit Maastricht

Maastricht, maart 1999 
Niets uit deze uitgave mag worden verveelvoudigd en/of openbaar gemaakt door middel van druk, fotocopie, microfilm, of op welke wijze ook, zonder voorafgaande schriftelijke toestemming van de directeur van het Researchcentrum voor Onderwijs en Arbeidsmarkt. In geval van overname van het data-materiaal moet telkens als bron worden vermeld: "Researchcentrum voor Onderwijs en Arbeidsmarkt" of "ROA". Van publicaties waarin gebruik wordt gemaakt van gegevens uit dit rapport ontvangen wij gaarne een exemplaar.

Hoewel de grootst mogelijke zorg is besteed aan de inhoud van dit rapport, kan het ROA in generlei opzicht verantwoordelijkheid op zich nemen voor eventuele onvolledigheden of onjuistheden.

\section{Colofon}

Vormgeving omslag Lenting en Terlingen Grafisch Ontwerp

Lay-out, dip en druk Unigraphic, Universiteit Maastricht

Oplage

800 exemplaren 


\section{Inhoudsopgave}

Voorwoord

Ten geleide

Resumé

1 De Limburgse arbeidsmarkt in vogelvlucht 1

1.1 Inleiding 1

1.2 De verwachte arbeidsmarktontwikkeling in 1999

1.3 Ontwikkelingen naar bedrijfssector 4

1.4 Ontwikkelingen naar beroepssector 7

$\begin{array}{lr}1.5 & \text { Ontwikkelingen naar opleidingsniveau } \\ 1.6 & 8\end{array}$

1.6 De participatiegraad in Limburg 10

2 De werkgelegenheidsstructuur in Limburg 13

2.1 Inleiding 13

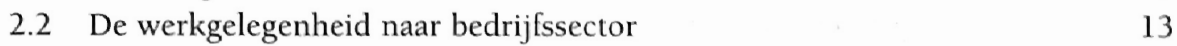

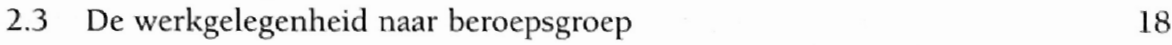

2.4 De werkgelegenheid naar opleidingstype 20

2.5 Specifieke groepen op de Limburgse arbeidsmarkt 22

3 Actuele discrepanties op de Limburgse arbeidsmarkt 27

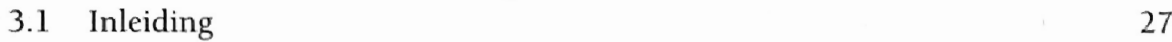

$\begin{array}{ll}3.2 & \text { Vacatures in Limburg } \\ 3.3 & 28\end{array}$

3.3 Werkzoekenden in Limburg 34

3.4 Kwantitatieve en kwalitatieve discrepanties in Limburg 41

$4 \quad$ De Limburgse arbeidsmarkt in 1999

4.1 Inleiding 53

4.2 Uitbreidingsvraag, vervangingsvraag en baanopeningen 58

4.3 Instroom van schoolverlaters op de arbeidsmarkt 64

4.4 Knelpunten in de personeelsvoorziening en arbeidsmarktperspectief

5 Knelpunten in perspectief $\quad 71$

$\begin{array}{lll}5.1 & \text { Inleiding } & 71\end{array}$

5.2 Knelpunten op de Limburgse arbeidsmarkt: oorzaken en oplossingen 71

5.3 Omvang en samenstelling van de Limburgse arbeidsreserve $\quad 78$

5.4 Aandachtspunten voor het participatiebeleid 85 
6 Scholing van werkzoekenden $\quad 87$

\begin{tabular}{ll}
6.1 & Inleiding \\
\hline
\end{tabular}

6.2 Scholingsbehoefte op de Limburgse arbeidsmarkt 90

6.3 Het bijscholingspotentieel in verhouding tot de bijscholingsbehoefte 93

6.4 Het karakter van de scholingsbehoefte 97

$\begin{array}{ll}6.5 \text { Aandachtspunten voor het scholingsbeleid } & 99\end{array}$

7 De arbeidsmarktpositie van opleidingen $\quad 103$

$\begin{array}{lll}7.1 & \text { Inleiding } & 103\end{array}$

$\begin{array}{ll}\text { 7.2 De arbeidsmarktpositie van schoolverlaters } & 103\end{array}$

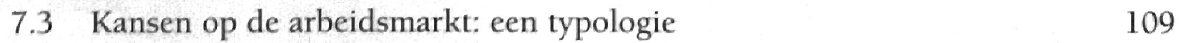

7.4 De onderwijscapaciteit in Limburg: de verwachte arbeidsmarktinstroom 115

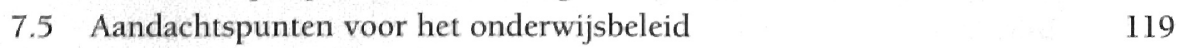

Verklarende woordenlijst 


\section{Voorwoord}

De Limburgse arbeidsmarkt is volop in beweging. De werkgelegenheid groeit en verandert van structuur. Als gevolg van onder meer ontgroening, vergrijzing en toenemende arbeidsparticipatie van vrouwen wijzigt de samenstelling van de beroepsbevolking. Steeds meer concurrentie vindt plaats om het steeds schaarser aanbod aan arbeidskrachten. Kortom: de arbeidsmarkt verandert en wordt steeds complexer van karakter. De krapte neemt snel toe.

Om de snel veranderende arbeidsmarkt in al haar facetten transparant te maken is het project Regionale Arbeidsmarkt Informatie Limburg (RAIL) in 1997 in het leven geroepen. Het project is een samenwerkingsverband tussen Arbeidsvoorziening Limburg, Provincie Limburg, het Regionaal Bureau Onderwijs Zuid-Limburg, de drie Regionale Opleidingen Centra, de Limburgse Werkgevers Vereniging en FNV Limburg. Ook de gemeenten zullen binnenkort in RAIL gaan participeren.

RAIL stelt zich ten doel huidige en verwachte ontwikkelingen aan de vraag- en aanbodkant van de Limburgse arbeidsmarkt in beeld te brengen. De nadruk ligt hierbij op het tijdig signaleren van onevenwichtige verhoudingen tussen arbeidsvraag en arbeidsaanbod.

De eerste publicatie van RAIL - De Limburgse arbeidsmarkt 1997-2002 - verscheen in maart 1998. Gesteld mag worden dat door RAIL de Limburgse arbeidsmarkt van nu en morgen een stuk inzichtelijker is geworden. Veel marktpartijen, waaronder werkgevers- en werknemersorganisaties, onderwijs- en scholingsinstellingen, intermediars en bedrijven hebben RAIL het afgelopen jaar geraadpleegd. Het afgelopen jaar zijn vele vragen over de arbeidsmarkt mede door RAIL beantwoord kunnen worden.

Voor $\mathrm{u}$ ligt de tweede publicatie van RAIL, die is samengesteld door het ROA in samenwerking met ETIL. Ten opzichte van vorig jaar is de methodiek om prognoses op te stellen en huidige en toekomstige marktdiscrepanties in beeld te brengen verfijnd. Op veler verzoek is verder gekozen voor een regionale differentiatie. Dit betekent dat nu ook afzonderlijke analyse voor de regio's Noord- en Midden-Limburg en Zuid-Limburg beschikbaar zijn.

In de afgelopen periode is intensief gebruik gemaakt van het netwerk van de samenwerkingspartners van RAIL om informatie over de arbeidsmarkt te ontsluiten. In dat kader zijn vele interviews afgenomen en zijn panels georganiseerd waaraan onder meer bedrijven en onderwijs- en scholingsinstellingen hebben deelgenomen. Gebleken is dat veel partijen over gedetailleerde kennis beschikken van de Limburgse arbeidsmarkı of van afzonderlijke segmenten daarbinnen. Deze kennis is opgenomen in het voorliggende rapport.

Een van de belangrijkste bevindingen is dat de krapte op de Limburgse arbeidsmarkı aanzienlijk is gestegen en dat discrepanties de komende jaren verder zullen toenemen. In het rapport wordt in dat kader ook stilgestaan bij een aantal mogelijkheden om in te spelen op actuele en toekomstige discrepanties. De komende jaren zal het steeds belangrijker worden om het beschikbare arbeidsaanbod zo goed mogelijk te benutten teneinde te kunnen voldoen aan de vraag naar personeel vanuit het bedrijfsleven. Dit betekent dat naast arbeidsinpassing van niet werkenden die zich beschikbaar hebben gesteld op de markı, ook 
gekeken dient te worden naar de mogelijkheden om personen naar de markt te begeleiden die nog niet actief op zoek zijn naar werk. RAIL brengt deze zogenaamde stille arbeidsreserve nader in beeld.

Wij hopen dat RAIL evenals vorig jaar voor veel partijen op de Limburgse arbeidsmarkt weer een goede spoorgids mag zijn. Een gids ook, die partijen zal aansporen en zal blijven stimuleren om de dialoog rondom de onevenwichtige verhouding tussen vraag en aanbod op de Limburgse arbeidsmarkt scherp te houden.

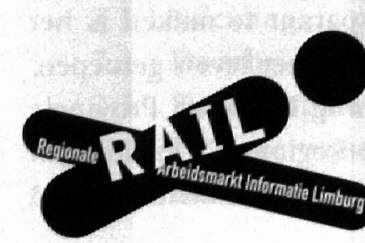

Voorzitter stuurgroep RAIL

J.D. Crena de Iongh 


\section{Verschenen RAIL publicaties:}

98.RAIL-01: De Limburgse arbeidsmarkt 1997-2002 (hoofdrapport)*)

98.RAIL-02: De Limburgse arbeidsmarkt 1997-2002 (statistische bijlage) ${ }^{*}$ )

98.RAIL-03: Kwalitatieve informatie over de Limburgse arbeidsmarkt: werkdocumenten industrie, handel *)

99.RAIL-04: De Limburgse arbeidsmarkt 1998-2002 (hoofdrapport)

99.RAIL-05: De Limburgse arbeidsmarkt 1998-2002 (statistische bijlage)

99.RAIL-06: De Limburgse arbeidsmarkt 1998-2002; sectorrapportage bouw - zakelijke dienstverlening - zorg

99.RAIL-07: De Limburgse arbeidsmarkt 1998-2002, beknopte rapportage

*) Publicatie niet meer in boekvorm verkrijgbaar.

\section{RAIL op internet}

www.limburg.arbeidsbureau.nl/RAIL/

www.railsite.nl (verkort adres) 


\section{Ten geleide}

Van verschillende kanten is er een behoefte aan betrouwbare informatie over de actuele en toekomstige arbeidsmarktsituatie in Limburg. Deze informatiebehoefte vormde de aanleiding tot het project Regionale Arbeidsmarkt Informatie Limburg (RAIL), dat beoogt te komen tot een geintegreerd informatiesysteem toegespitst op de provincie Limburg. In het RAILproject participeren Arbeidsvoorziening Limburg, de Provincie Limburg, het Regionaal Bureau Onderwijs (RBO) Zuid-Limburg, de Regionale Opleidingscentra (ROC's), de Federatie Nederlandse Vakbeweging (FNV) en de Limburgse Werkgevers Vereniging (LWV). Er wordt derhalve samengewerkt door een aantal partners die zowel gebruiker als leverancier van informatie zijn.

Het thans voor U liggende rapport De Limburgse arbeidsmarkt 1998-2002 vormt de tweede versie van het overzichtsrapport dat het Researchcentrum voor Onderwijs en Arbeidsmarkt (ROA), in samenwerking met het Economisch Technologisch Instituut Limburg (ETIL), in

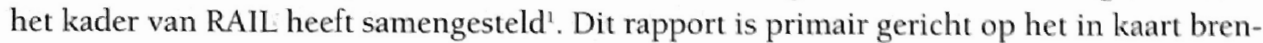
gen van de actuele en toekomstige discrepanties naar bedrijfssector, beroep en opleiding op de Limburgse arbeidsmarkt. Tegelijkertijd met dit rapport verschijnt ook de bijbehorende Statistische Bijlage. Hierin wordt een systematisch kwantitatief overzicht gegeven van de verwachte arbeidsmarktontwikkelingen en de actuele arbeidsmarktgegevens die ten grondslag liggen aan dit hoofdrapport. Bovendien verschijnt er een beknopte rapportage waarin de belangrijkste bevindingen en conclusies worden weergegeven.

Teneinde de discrepanties zo goed mogelijk in kaart te brengen omvat het informatiesysteem niet alleen kwantitatieve informatie, maar ook kwalitatieve informatie. De kwalitatieve informatie is verzameld en gegenereerd door ETIL. Deze informatie biedt de mogelijkheid om specifieke aspecten van de Limburgse arbeidsmarktproblematiek in kaart te brengen. De kwalitatieve informatie is gericht op drie speerpuntsectoren: de bouw, de zakelijke dienstverlening en de zorg. De inzichten en conclusies die voortkomen uit de kwalitatieve informatie zijn verwerkt in de door ETIL samengestelde RAIL-publicatie De Limburgse arbeidsmarkt 1998-2002; sectorrapportage bouw * zakelijke dienstverlening * zorg die gelijktijdig met dit hoofdrapport is verschenen.

Dit hoofdrapport is gebaseerd op zowel de kwantitatieve als de kwalitatieve informatic. Centraal hierbij staat het streven om zoveel mogelijk het complementaire karakter van de informatie te benutten. Hierbij biedt de kwantitatieve informatie een raamwerk dat met behulp van de kwalitatieve informatie nader is ingekleurd, verdiept en verbijzonderd, opdat een systematisch en gedetailleerd beeld van de aansluitingsproblematiek in de regio verkregen wordt. Door zowel de huidige situatie als de toekomstige ontwikkelingen op zowel kwantitatieve als kwalitatieve wijze in kaart te brengen, heeft RAIL een signaleringsfunctie voor diverse gebruiksdoelen. Hierbij kan gedacht worden aan het personeels- en rekruteringsbeleid van werkgevers, het initièren en bijsturen van bij- en omscholingspro-

I In 1998 is de eerste versie van het RAIL-rapport verschenen. Zie P. van Eijs, el al, De Limburgse arbeids markı 1997-2002, ROA-R-1998/3, Researchcentrum voor Onderwijs en Arbeidsmarkı, Maastricht, 1998. 
gramma's voor werkzoekenden, de arbeidsbemiddeling, het (provinciale) arbeidsmarktbeleid en het onderwijsbeleid.

In het voorliggende rapport wordt slechts in beperkte mate ingegaan op de gehanteerde onderzoeksmethoden, de gehanteerde classificaties, e.d. Daarvoor wordt verwezen naar het nog te verschijnen werkdocument Methodiek Regionale Arbeidsmarkt Informatie Limburg (RAIL). Achterin dit rapport zijn enkele centrale begrippen uit dit rapport op een rij gezet en nader omschreven. Daarnaast wordt in het rapport, waar nodig, uitleg gegeven over de gebruiksmogelijkheden van de gepresenteerde informatie.

In dit rapport is op verschillende manieren vorm gegeven aan een verdere verbreding en verdieping van het RAIL-informatiesysteem in vergelijking met het afgelopen jaar. Ten eerste is verder gezocht naar de optimale classificaties, gegeven de kwaliteit van de data en de daadwerkelijke verschillen tussen verschillende arbeidsmarktsegmenten (i.c. bedrijfssectoren, beroepen, opleidingen en subregio's). Dit heeft geresulteerd in meer gedetailleerde cijfers ten aanzien van de Limburgse werkgelegenheidsstructuur. Ten tweede wordt de omvang en de samenstelling van de stille arbeidsreserve in beeld gebracht. Daarbij wordt ook ingegaan op de mogelijkheden om via het activeren van de stille arbeidsreserve de knelpunten op de Limburgse arbeidssmarkt te verminderen. Ten derde worden de knelpunten naar beroep in kaart gebracht. Op de vierde plaats is de naamgeving van de verschillende opleidingstypen in dit rapport in overeenstemming gebracht met de nieuwe kwalificatiestructuur zoals die is vastgelegd in de WEB (Wet Educatie en Beroepsonderwijs). Ten slotte is een eerste aanzet gegeven tot het verkrijgen van inzicht in de kwaliteit van de aansluiting tussen onderwijs en arbeidsmarkt met behulp van schoolverlatersinformatie. Hiervoor wordt gebruik gemaakt van de RUBS-enquête (Registratie van Uitstroom en Bestemming van Schoolverlaters). Dit is een landelijke enquête onder schoolverlaters van het beroepsonderwijs.

Het rapport bestaat uit een resumé en zeven hoofdstukken. De eerste vier hoofdstukken geven een overzicht van de huidige en toekomstige ontwikkelingen op de Limburgse arbeidsmarkt. In hoofdstuk 1 wordt een globaal overzicht gegeven van de belangrijkste arbeidsmarktontwikkelingen verbijzonderd naar bedrijfssector, beroep en opleiding. Hoofdstuk 2 schetst een beeld van de belangrijkste ontwikkelingen en kenmerken van de Limburgse werkgelegenheidsstructuur naar sector, beroep, opleiding en subregio. In hoofdstuk 3 wordt getracht een antwoord te geven op de vraag in hoeverre er op dit moment voldoende geschikte werkzoekenden beschikbaar zijn om de openstaande vacatures te vervullen en in hoeverre er voldoende vacatures zijn om de werkzoekenden aan een baan te helpen. Daarbij gaat het zowel om de kwantitatieve als de kwalitatieve discrepanties op de Limburgse arbeidsmarkt. Hoofdstuk 4 gaat nader in op de te verwachten ontwikkelingen op de korte termijn aan zowel de vraag- als de aanbodzijde van de Limburgse arbeidsmarkt, hetgeen resulteert in een overzicht van de te verwachten discrepanties tussen vraag en aanbod naar opleiding en beroep in 1999?

2 Er zijn dit jaar geen nieuwe middellange-termijnprognoses opgesteld. De ervaring van het ROA leert dat de additionele informatieve waarde van het jaarlijks aanpassen van de middellange-termijnprognoses aan de nieuwste inzichten in de verwachte ontwikkelingen aan de vraag-en de aanbodzijde van de arbeidsmarkt relatief gering is. 
In hoofdstuk 5 worden de gesignaleerde actuele en toekomstige discrepanties op twee manieren in een nader perspectief geplaatst. Eerst wordt ingegaan op de achtergronden van de tekorten aan geschikt personeel in de drie sectoren die dit jaar in het RAIL-project nader onder de loep zijn gehouden: de bouw, de zakelijke dienstverlening en de zorg. De in de hoofdstukken 3 en 4 gesignaleerde knelpunten roepen de vraag op in hoeverre het bevorderen van de arbeidsmarktparticipatie in Limburg soelaas kan bieden. Daarom wordt in het tweede deel van hoofdstuk 5 een indicatie gegeven van de mogelijkheden om via het bevorderen van de arbeidsmarktparticipatie de knelpunten op de Limburgse arbeidsmarkt te verminderen.

In hoofdstuk 6 ligt de nadruk op de mogelijkheden om via scholing van de werkzoekenden de te verwachten discrepanties op de Limburgse arbeidsmarkt te verminderen. In dit hoofdstuk wordt een raamwerk gepresenteerd dat per beroepsgroep inzicht verschaft in de onderliggende oorzaken van de kwantitatieve en kwalitatieve discrepanties op de Limburgse arbeidsmarkt. Bovendien biedt dit raamwerk de mogelijkheid deze inzichten te vertalen in richtlijnen voor bij- en omscholingsprogramma's. Dit hoofdstuk mondt dan ook uit in een overzicht van beroepsgroepen, waarin bij- en omscholing van werkzoekenden een effectief beleidsinstrument kan vormen om de discrepanties op de Limburgse arbeidsmarkt te verminderen.

In hoofdstuk 7 wordt de actuele en de toekomstige arbeidsmarktpositie van de verschillende opleidingen waarvoor er daadwerkelijk sprake is van een regionale arbeidsmarkt nader belicht. Het gaat hierbij om de opleidingen op VBO- en MBO-niveau. Als eerste komt de actuele arbeidsmarktpositie van schoolverlaters van het MBO aan de orde. Daarbij wordt er eerst een totaalbeeld voor het MBO gepresenteerd. Daarna zal worden ingegaan op een aantal specifieke $\mathrm{MBO}$-opleidingen. Vervolgens wordt gekeken naar de verwachte arbeidsmarktperspectieven op de middellange termijn, de conjunctuurgevoeligheid van de werkgelegenheid op de verschillende arbeidsmarktsegmenten en de uitwijkmogelijkheden op de arbeidsmarkt. Dit hoofdstuk mondt uit in een aantal richtlijnen voor het onderwijsbeleid uit oogpunt van de macrodoelmatigheid van het Limburgs onderwijs.

De projectleiding van RAIL is bij het ROA in handen van P. van Eijs en A. de Grip. Aan de huidige versie van het hoofdrapport en de bijbehorende Statistische Bijlage is bij het ROA meegewerkt door J. Delmee, B. Diephuis, M. van Dijk, J. van Loo, G. Nekkers en J. Sanders. Bij ETIL is de projectleiding van RAIL in handen van $H$, van Camp. In het licht van de integratie van de kwalitatieve informatie is zij mede-auteur van dit hoofdrapport.

Onze dank gaat uit naar de leden van de RAIL-stuurgroep en -projectteam. De volgende personen hebben hierin zitting: J. Crena de Iongh (DSM, voorzitter stuurgroep), G. Ahn (Arbeidsvoorziening Limburg, secretaris), M. te Baerts (Leeuwenborgh Opleidingen), T. Beenackers-Oomen (RBO Zuid-Limburg), H. Droppert (Arbeidsvoorziening Limburg), E. Dols (Leeuwenborgh Opleidingen), H. Duijvestein (Arbeidsvoorziening Limburg, projectleider), H. Frinking (Arbeidsvoorziening Facilitair Bedrijfl), W. Huurdeman (Gilde Opleidingen), H. de Jong (Provincie Limburg), W. Kohl (Arcus College), P. Peters (Arcus College), J. Schobben (Arcus College), L. Simons-Heldens (Gilde Opleidingen), M. van Smoorenburg (Arbeidsvoorziening Limburg), J. Soogelée (Leeuwenborgh Opleidingen), A. Snels (FNV Limburg), G. Wolfs (Provincie Limburg) en L. Zeegers (LWV). 


\section{Resumé}

\section{Recente ontwikkelingen in de Limburgse werkgelegenheid}

De Limburgse werkgelegenheid is de laatste jaren sterk gegroeid. De afgelopen twee jaar was de groei gemiddeld genomen ruim 3\%. Terwijl de economische groei in Limburg duidelijk hoger is dan landelijk, blijft de werkgelegenheidsgroei, evenals de afgelopen jaren, enigszins achter. Hieraan ligt onder meer het industriële karakter van de werkgelegenheid ten grondslag. In de industrie wordt de economische groei voor een belangrijk deel gerealiseerd door middel van een toename van de arbeidsproductiviteit. Het is daarom niet verrassend dat ondanks de groei van de produktie de werkgelegenheid in een aantal industriële sectoren in Limburg is gedaald.

Het industriële karakter van de werkgelegenheid is het sterkst in het noordelijk deel van de provincie. In het zuiden, waar de dienstensector een veel groter deel van de werkgelegenheid voor zijn rekening neemt, zijn de verschillen met het landelijke beeld veel geringer. Ondanks het industriële karakter van de werkgelegenheid is ook in Limburg sprake van een verdergaande verdienstelijking. Deze verdienstelijking van de werkgelegenheid brengt steeds hogere opleidingseisen met zich mee. Het gemiddeld opleidingsniveau van de werkenden in de dienstensector en bij de overheid is namelijk veel hoger dan in de industrie en de landbouw.

Opvallend is ook het relatief geringe aandeel van flex-werkers in de Limburgse werkgelegenheid. Landelijk heeft 10 procent van de werkenden een flexibel arbeidscontract; in Limburg is dit wat geringer, namelijk $8 \%$. In een aantal sectoren is er in Limburg echter wel sprake van een duidelijk stijgende trend in het aandeel flexibele arbeidscontracten.

\section{Actuele knelpunten op de Limburgse arbeidsmarkt}

De krapte op de Limburgse arbeidsmarkt is de afgelopen tijd aanzienlijk toegenomen. De vacaturegraad en het percentage moeilijk vervulbare vacatures zijn aanzienlijk gestegen. Door de krapte op de arbeidsmarkt is het aantal niet-werkende werkzoekenden sterk afgenomen. In totaal is er in Limburg een afname van de werkloosheid van ruim 59.000 in 1997 naar ongeveer 43.000 in 1998. Dit is een daling van maar liefst meer dan $25 \%$. Daarentegen is, hoewel de absolute aantallen zijn gedaald, zowel het aandeel van werkzoekenden met een grote afstand tot de arbeidsmarkt (bemiddelingsfase 4) als het aandeel langdurig werklozen toegenomen. Dit is een weerspiegeling van het feit dat, naarmate het antal vacatures stijgt, de werkzoekenden met een geringe afstand tot de arbeidsmarkt doorgaans het eerst emplooi vinden.

De verkrapping van de arbeidsmarkt blijkt duidelijk uit het feit dat de verhouding tussen het aantal openstaande vacatures en het aantal direct bemiddelbare werklozen met een geringe afstand tot de arbeidsmarkt (bemiddelingsfase 1) tussen 1997 en 1998 een radicale omwenteling heeft laten zien. In 1997 overtrof het aantal direct inzetbare werklozen het aantal openstaande vacatures. Voor elke 100 direct inzetbare werklozen waren er minder dan 50 openstaande vacatures beschikbaar. De situatie in 1998 is echter radicaal veranderd. 
Thans zijn er per 100 direct bemiddelbare werklozen maar liefst ruim 200 openstaande vacatures beschikbaar. Het is in ruim één jaar dus aanzienlijk moeilijker geworden geschikt personeel te vinden om vacatures te vervullen.

De meeste bedrijfssectoren worden geconfronteerd met een krappe arbeidsmarkt. De problemen zijn het grootst in de commerciële dienstverlening. Dit sluit aan bij het beeld dat in het vorig jaar verschenen RAIL-rapport De Limburgse arbeidsmarkt 1997-2002 is geschetst. Voor het bank- en verzekeringswezen en de horeca, reparatie en zakelijke dienstverlening staan alle indicatoren op rood. Deze sectoren worden geconfronteerd met een groot tekort aan direct inzetbare werklozen. De bedrijven in deze sectoren hebben daardoor moeite om vacatures op korte termijn te vervullen, waardoor er sprake is van een hoog percentage moeilijk vervulbare vacatures. Daarbij staat de rekrutering extra onder druk vanwege het verhoudingsgewijs grote aantal vacatures (de zogenaamde vacaturegraad) in deze sectoren.

Ook in de industrie is er sprake van een grote arbeidsmarktkrapte. Het aantal openstaande vacatures overtreft het aanbod van direct bemiddelbare werklozen. De vacaturegraad en het percentage langdurig openstaande vacatures liggen daarentegen op een wat lager niveau. Dit betekent dat de industrie te kampen heeft met een tekort aan direct inzetbaar personeel in specifieke beroepen. Het aantal openstaande vacatures is echter niet uitzonderlijk hoog. Bovendien is de industrie nog altijd redelijk goed in staat op de korte termijn de vacatures te vervullen. Blijkbaar is de aanzuigende werking van de grote industriële bedrijven zo groot dat het (schaarse) arbeidsaanbod op de voor deze bedrijven relevante arbeidsmarktsegmenten vaak voor een functie in de industrie kiest.

Op de arbeidsmarktsegmenten waar de landbouw, de bouw en de kwartaire diensten hun personeel werven is er weliswaar sprake van krapte; in verhouding to de hierboven genoemde sectoren is deze echter beperkt. Deze 'sectoren hebben slechts te kampen met zeer specifieke knelpunten in de personeelsvoorziening.

Met name in de technische en de automatiseringsberoepen en opleidingen is het tekort aan personeel kwantitatief van aard. Er zijn eenvoudigweg te weinig werkzoekenden in het betreffende segment beschikbaar. In de administratieve en verzorgende beroepen en opleidingen heeft het tekort aan personeel vooral een kwalitatief karakter. Er is weliswaar voldoende aanbod maar dit aanbod voldoet niet aan de gestelde eisen: de afstand tot de arbeidsmarkt is te groot.

\section{De Limburgse arbeidsmarkt in 1999}

De economische groei die Limburg de laatste jaren doormaakt zal zich naar verwachting in 1999 voortzetten. Deze gunstige verwachtingen resulteren in een werkgelegenheidsgroei van ongeveer $2 \%$. Dit is een groei van maar liefst bijna 10.000 banen. De vergrijzing van de Limburgse beroepsbevolking heeft tot gevolg dat de arbeidsmarktuitstroom steeds verder toeneemt. Voor 1999 wordt verwacht dat maar liefst ruim 5\% van de werkenden in Limburg de arbeidsmarkt door pensionering, vervroegde uittreding, arbeidsongeschiktheid, e.d. zal verlaten. De vervangingsvraag op de arbeidsmarkt zal daardoor groot zijn. 
Door de hoge werkgelegenheidsgroei en arbeidsmarktuitstroom zullen er naar verwachting ongeveer 33.000 baanopeningen voor nieuwkomers op de arbeidsmarkt zijn's. Dit grote aantal baanopeningen laat zien dat de enigszins teruglopende werkgelegenheidsgroei slechts een gering effect heeft op de behoefte van werkgevers aan nieuw personeel. Immers, ruim twee-derde van het totale aantal baanopeningen vloeit voort uit de vervangingsbehoefte op de arbeidsmarkt.

Aan de aanbodzijde van de arbeidsmarkt eist de ontgroening zijn tol. Het aantal jongeren daalt. Bovendien volgen jongeren steeds langer een dagopleiding, waardoor hun intrede op de arbeidsmarkt wordt uitgesteld. Het aantal schoolverlaters dat instroomt op de arbeidsmarkt zal als gevolg van deze ontwikkelingen de komende jaren verder dalen. In 1999 zullen in totaal ruim 14.000 schoolverlaters op de Limburgse arbeidsmarkt op zoek gaan naar een baan.

De schoolverlaters die hun intrede doen op de arbeidsmarkt worden daardoor gewilde kandidaten voor de werkgevers die op zoek zijn naar nieuw personeel. De meeste schoolverlaters hebben daardoor gunstige arbeidsmarktperspectieven. In dit rapport ligt de nadruk op de opleidingen op MBO-niveau en lager. Voor 1999 wordt voor bijna $60 \%$ van de in dit rapport onderscheiden opleidingstypen op lager en middelbaar niveau een goed tot zeer goed perspectief verwacht. Met name op MBO-niveau zijn de perspectieven voor nieuwkomers op de arbeidsmarkt in Limburg goed. Voor 1999 zal voor de nieuwkomers op de arbeidsmarkt van ruim $80 \%$ van de $\mathrm{MBO}$-opleidingstypen het perspectief goed tot zeer goed zijn. Voor degenen met een HAVO- of VWO-opleiding is het arbeidsmarktperspectief daarentegen slechts matig. Ook voor VBO'ers en voor mensen met een MAVO-opleiding of slechts Basisonderwijs is het perspectief minder goed. Aangezien de werkgelegenheid voor ongeschoolden naar verwachting zal krimpen komen er alleen banen vrij voor 'drop-outs' uit het voorgezet onderwijs vanwege de vervangingsbehoefte van bedrijven en instellingen. Daar staat tegenover dat de verwachte arbeidsmarktinstroom van laaggeschoolden naar verwachting relatief gering zal zijn, omdat steeds meer laag opgeleiden kiezen voor een vervolgopleiding. Dit betekent dat het perspectief van direct bemiddelbare laag opgeleiden op de Limburgse arbeidsmarkt in 1999 als 'redelijk' kan worden getypeerd. Hierbij moet echter wel de kanttekening worden geplaatst dat slechts een gering deel van de laaggeschoolde werklozen als direct bemiddelbaar wordt beschouwd.

Vanuit werkgeversoogpunt betekenen de goede arbeidsmarktperspectieven voor de nieuwkomers op de arbeidsmarkt dat er knelpunten zullen optreden in de personeelsvoorziening. Het aanbod van direct inzetbare arbeidskrachten is dan immers kleiner dan het aantal baanopeningen. Dit betekent dat werkgevers problemen zullen ondervinden bij het aantrekken van nieuw personeel. In Limburg zullen dus met name op MBO-niveau de knelpunten in de personeelsvoorziening in 1999 aanzienlijk zijn. Dergelijke arbeidsmarktknelpunten zouden een remmende factor kunnen vormen voor de economische groei in de provincie. Dit temeer daar middelbaar opgeleiden een strategische rol spelen in de concurrentieposi-

3 Het aantal vacatures zal waarschijnlijk veel hoger liggen. Immers, als een vacature wordt ingevuld met iemand die ergens anders werkzaam was, ontstaat er vaak weer een nieuwe vacature op de plek die deze werknemer achterlaat. Door deze zogenaamde 'vacature-ketens' schommelt het aantal vacatures doorgaans veel sterker dan het echte aantal baanopeningen voor nieuwkomers op de arbeidsmarkt. 
tie van het bedrijfsleven. Daarbij gaat het niet zozeer om het innovatieve potentieel van de beroepsbevolking, maar vooral om de kwaliteit van de produktie en de dienstverlening.

\section{Uitgelicht: huidige en toekomstige knelpunten in de bouw}

Op de arbeidsmarkt voor de bouwberoepen is er momenteel weliswaar sprake van krapte; in verhouding tot het algemene beeld is deze echter beperkt. De belangrijkste problemen doen zich voor bij de (assistent) straatmakers, de steigerbouwers, de schilders, de all-round vaklieden burger- en utiliteitsbouw en grond-, weg- en waterbouw, de monteurs, de calculatoren, de werkvoorbereiders, het grond-, weg- en waterbouw-middenkader en het hoger kader. Naast een adequate opleiding wordt bij uitvoerende vakkrachten klantvriendelijkheid steeds belangrijker geacht. Bij leidinggevenden worden sociaal-communicatieve vaardigheden en overtuigingskracht steeds belangrijker.

Voor de wervingsproblemen in de bovenstaande beroepen zijn twee belangrijke oorzaken aan te wijzen: de geringe instroom van jongeren in de technische opleidingen in het algemeen en de bouwopleidingen in het bijzonder en het slechte imago van het werk.

Op termijn, en zeker voor 1999, wordt geen vermindering van de knelpunten verwacht. Gezien de omvangrijke vervangingsbehoefte zullen de knelpunten in de hierboven genoemde beroepen zich ook volgend jaar manifesteren. Een eventuele economische terugval zal hier naar verwachting relatief weinig invloed op hebben; met name de behoefte aan vakmensen - zowel all-round als specialistisch - blijft naar verwachting groot. Er is een groeiende behoefte aan gekwalificeerd personeel (kwalificatieniveau 3), ten koste van het laag-opgeleid personeel (kwalificatieniveau 1 en 2).

De sector draagt verschillende oplossingsrichtingen voor de knelpunten in de personeelsvoorziening aan. Het individuele bouwbedrijf kan, naast het werven van alternatieve categorieën, de knelpunten in de personeelsvoorziening verminderen door aanpassingen binnen de organisatie (functie-splitsing, job-rotation, verdergaande professionalisering en het vergroten van de mogelijkheden om in deeltijd te werken) en de scholing van personeel teneinde de doorstroom naar hogere functies te bevorderen. Gezamenlijk kunnen de bouwbedrijven onder andere trachten het imago van het werk in de sector te verbeteren en banenpools te creëren. Ten slotte is de samenwerking van de bouwsector met het onderwijs van belang. Het vergroten van de aantrekkelijkheid van het onderwijs kan een centrale rol spelen bij het verbeteren van het imago van het werken in de sector. Het gaat hierbij niet alleen om de inhoud van de opleiding, maar bijvoorbeeld ook om het bieden van een opleiding in de regio en het aanbieden van avondopleidingen in deeltijd. Bovendien is het vergroten van het rendement van de opleidingen van belang. Hierbij gaat het zowel om het vergroten van de uitstroom naar de arbeidsmarkt, maar ook om de doorstroom naar vervolgopleidingen (met name van niveau 2 naar niveau 3 ).

\section{Uitgelicht: huidige en toekomstige knelpunten in de zakelijke dienstverlening}

De zakelijke dienstverlening wordt in Limburg geconfronteerd met een krappe arbeidsmarkt. De bedrijven in de zakelijke dienstverlening ondervinden, vergeleken met het gemiddelde Limburgse beeld, relatief veel moeite geschikt personeel te vinden. De belang- 
rijkste knelpunten in de personeelsvoorziening blijken zich voor te doen bij de beveiligingsbeambten, de telefonistes en secretaresses, de commerciēle functies in de buitendienst (in het bijzonder assurantiemedewerkers), de medewerkers call-centers en telemarketing, de accountants, de informatici (zowel soft-als hard-ware), de management-consultants en de leidinggevenden (zowel algemeen als specifiek: ICT, financieel-economisch). De eisen die aan potentiële kandidaten voor deze functies worden gesteld zijn divers. Het juiste denk-en werkniveau met goede sociaal-communicatieve vaardigheden en de bereidheid om in zichzelf te blijven investeren staan centraal. Voor de leidinggevenden zijn bovendien resultaatgerichtheid en inlevingsvermogen van belang.

Voor de wervingsproblemen in de zakelijke dienstverlening zijn verschillende oorzaken aan te wijzen. Er is sprake van een beperkte nieuwe instroom. Daarnaast zijn er te weinig ervaren krachten beschikbaar. Bovendien levert de grote dynamiek in de sector problemen op. Het is een dynamische, snel groeiende sector. De uitbreidingsvraag is daarom groot. Het gaat hierbij vaak om nieuwe functies. Daarnaast is er sprake van snelle technologische ontwikkelingen. Kennis veroudert door deze technologische ontwikkelingen snel, waardoor er continu vraag is naar gekwalificeerd personeel. De concurrentie is daarom groot. Met name kleine bedrijven (als gevolg van de slechtere arbeidsvoorwaarden, het mindere carrièreperspectief en de kleinere opleidingsmogelijkheden) zijn hierbij in het nadeel.

Op termijn worden, met name op middelbaar en hoger niveau, op steeds bredere schaal knelpunten in de personeelsvoorziening verwacht. Bovendien ontstaan binnen de zakelijke dienstverlening steeds nieuwe functies, met name doordat in bepaalde functies vakgebieden gecombineerd moeten worden. Het gaat hier vooral om combinaties tussen ICT-, financieeleconomische en commerciële vaardigheden. Daarnaast worden adviesvaardigheden, gecombineerd met sociaal-communicatieve vaardigheden, steeds belangrijker. Tenslotte wordt steeds meer de nadruk gelegd op flexibiliteit en een brede inzetbaarheid. Dit resulteert in veel gevallen per saldo in een verhoging van het voor het werk vereiste opleidingsniveau.

Gedurende een reeks van jaren worden werkzoekenden omgeschoold om de knelpunten op de arbeidsmarkt voor de bedrijven in de zakelijke dienstverlening te verminderen: De sector beseft dat dit een tijdelijke oplossing is. Het is beter om te investeren in een structurele relatie met het onderwijs. Andere oplossingsrichtingen worden gezocht in het (verder) professionaliseren van het personeels- en opleidingsbeleid. Daarbij staat behoud en doorstroom van het eigen personeel voorop (bijvoorbeeld vrouwen en ervaren krachten). Bovendien zouden bedrijven meer moeten samenwerken op het gebied van personeel. Gedacht kan worden aan mobiliteitsplannen en structurele personeelsuitwisselingen.

\section{Uitgelicht: huidige en toekomstige knelpunten in de zorg}

In algemene zin blijkt de arbeidsmarkt in de kwartaire sector (waaronder de zorg valt) wat minder gespannen in vergelijking met het gemiddelde beeld op de Limburgse arbeidsmarkt. Het aantal moeilijk vervulbare vacatures neemt echter toe. De belangrijkste knelpunten in de personeelsvoorziening in de zorgsector doen zich voor bij de kraamverzorgenden en verzorgenden individuele gezondheidszorg, de intensive-care- en kinderverpleegkundigen, de apothekersassistenten, de röntgen- en diagnostisch laboranten en de automatiseerders. Daarnaast is er een tekort aan flex-krachten en vervangers op alle niveaus. Naast vakin- 
houdelijk-specialistische kennis spelen in de zorg het goed kunnen omgaan met kwetsbare mensen (alle beroepen), sociaal-communicatieve vaardigheden, patiēntgerichtheid, levenservaring, teamgeest, stabiliteit en zelfstandigheid een belangrijke rol.

De achtergronden van de moeilijk vervulbare vacatures in de zorg zijn divers. De ontgroening eist ook in de zorg zijn tol; steeds minder jongeren volgen een zorgopleiding. Een bijkomend probleem vormt de beschikbaarheid van opleidingsplaatsen. Daarnaast heeft het werk in de zorg een slecht imago. De slechte arbeidsvoorwaarden spelen hierbij een belangrijke rol. Door de aanwezigheid van verschillende CAO's binnen de zorg is er een sterke concurrentie op de arbeidsmarkt tussen de verschillende zorginstellingen. Hierbij hebben vooral de verzorgingshuizen een zwakke positie. Bovendien is er niet altijd sprake van een professioneel personeels- en opleidingsbeleid, waardoor de doorstroom- en carrièremogelijkheden gering zijn.

Op termijn moet in de zorgsector rekening worden gehouden met een verbreding van de wervingproblematiek. Op de middellange termijn worden voor de volgende beroepsgroepen wervingsproblemen verwacht: huishoudelijke dagelijkse hulpen voor levensverzorging (niveau 2), helpenden op MBO-niveau (niveau 2), verzorgenden individuele gezondheidszorg op MBO-niveau (niveau 2), verpleegkundigen op MBO-niveau (niveau 4), HBOverpleegkundigen, tandartsen en huisartsen. Mede als gevolg van de geringe instroom zullen er knelpunten in de personeelsvoorziening op middelbaar en hoger niveau voelbaar zijn. Daarnaast zal er naar verwachting over het algemeen een tekort zijn aan ervaren arbeidskrachten. Bij deze knelpunten speelt niet alleen de ontgroening een rol, maar ook het beperkte aantal opleidingsplaatsen. Een tweede belangrijke factor is de vergrijzing van de bevolking. Niet alleen leidt de vergrijzing tot een toenemende vervangingsbehoefte; door de toename van het aantal ouderen neemt ook de vraag naar zorg verder toe.

Gediplomeerde schoolverlaters en 'stagiaires' zijn altijd een belangrijke doelgroep geweest in de personeelsvoorziening van de zorginstellingen. De werkgevers in de zorg moeten zich tegenwoordig echter bij de werving van schoolverlaters anders opstellen. Kwamen voorheen de afgestudeerden uit de inservice-opleiding in dienst, nu moeten gediplomeerden geworven worden uit het reguliere onderwijs. De bredere opleiding bevordert echter de flexibiliteit en de mobiliteit aangezien jongeren sneller ingewerkt kunnen worden.

Direct inzetbaar personeel, met name schoolverlaters, wordt steeds schaarser. Dit betekent dat alternatieve wervingscategorieën steeds meer in beeld komen. De ervaringen met deze alternatieve groepen in de zorg zijn veelal positief. In het algemeen geldt echter wel dat voor het welslagen van de integratie van nieuwe wervingscategorieën er een intensieve begeleiding nodig is, eventueel gecombineerd met een opleidingstraject. Andere oplossingen voor de knelpunten worden door de zorgsector vooral gezocht bij de instellingen zelf. Hierbij wordt gedacht aan het bevorderen van goed werkgeverschap (arbeidsvoorwaarden, opleidingsmogelijkheden, loopbaanbeleid, e.d.), het bevorderen van de mobiliteit, het vergroten van de functie-differentiatie, het openbreken van contracten en het bevorderen van contacten met ex-medewerkers en stagiaires. Gezamenlijk kan de zorgsector onder meer bijdragen aan het verbeteren van het imago van het werk in de sector en een intensievere samenwerking tussen bijvoorbeeld dokterspraktijken en zorginstellingen. Ook op het terrein van de relatie met het onderwijs zijn er mogelijkheden: het intensiveren van de contacten en de 
samenwerking, het voeren van een doelgroepenbeleid, het nog verder verbreden van de opleiding, het starten van verkorte opleidingen en deeltijdopleidingen, e.d.

\section{Het bevorderen van de arbeidsmarktparticipatie}

Gezien de verwachting dat de knelpunten op de arbeidsmarkt de komende jaren zullen voortduren, kan de vraag gesteld worden in hoeverre het bevorderen van de participatie van de niet-actieven in het arbeidsproces soelaas kan bieden. Het blijkt dat 80 à 90.000 middelbaar en hoger opgeleide Limburgers niet participeren op de arbeidsmarkt of werkloos zijn. Vanuit een macro-optiek vormen zij een aantrekkelijk potentieel om de tekorten aan direct inzetbaar personeel te verminderen. Deze groep bestaat met name uit vrouwen. In Limburg zijn er ongeveer 65.000 vrouwen die minimaal een opleiding op MBO-niveau hebben afgerond, maar thans geen betaald werk hebben. Het bevorderen van de arbeidsmarktparticipatie zal, naast eventuele investeringen in scholing, bijvoorbeeld gericht op herintredende vrouwen, ook een flankerend beleid vereisen zoals het bevorderen van de mogelijkheden voor kinderopvang.

Er is ook een verrassend grote groep goed opgeleide jongeren die niet participeert op de Limburgse arbeidsmarkt. Ruim 30.000 middelbaar en hoger opgeleide Limburgers jonger dan 30 jaar hebben geen betaald werk. Deze groep overlapt natuurlijk de eerder genoemde vrouwen met minimaal een MBO-opleiding voor een belangrijk deel. Gezien het feit dat het potentieel aan goed opgeleide niet-actieven vooral uit vrouwen bestaat, kan het stimuleren van de arbeidsmarktparticipatie vooral in het licht van de tekorten aan verplegend personeel, secretarieel personeel, winkel- en horecapersoneel een effectieve maatregel zijn. De participatiegraad van technisch opgeleiden ligt op een veel hoger niveau. Het bevorderen van de arbeidsmarktparticipatie van technisch opgeleiden zal derhalve slechts een geringe bijdrage kunnen leveren aan het terugdringen van de knelpunten op de Limburgse arbeidsmarkt.

\section{Het scholingsbeleid}

Bij- en omscholing van werkzoekenden kan een effectief middel zijn om discrepanties tussen vraag en aanbod op de arbeidsmarkt te verminderen. Door middel van bijscholing kunnen aansluitingsproblemen tussen de kennis en vaardigheden waarover de werkzoekenden op een bepaald arbeidsmarktsegment beschikken en de in dat segment gevraagde kennis en vaardigheden verminderd worden. Met andere woorden: bijscholing kan een effectief middel zijn om kwalitatieve aansluitingsproblemen in een bepaald arbeidsmarktsegment het hoofd te bieden. Door middel van omscholing kunnen knelpunten op de arbeidsmarkt, die hun oorsprong vinden in het feit dat er in een specifiek arbeidsmarktsegment geen werkzoekenden beschikbaar zijn om aan de vraag te voldoen, verminderd worden. Omscholing van werkzoekenden die zijn opgeleid voor een beroepsgroep waarvoor er sprake is van een overschot, kan dus een effectief middel zijn om kwantitatieve aansluitingsproblemen op andere arbeidsmarktsegmenten te verminderen. Aansluitingsproblemen hebben overigens niet alleen betrekking op vakinhoudelijke kennis en vaardigheden. Ook werkhouding, communicatieve vaardigheden, de wil om te blijven leren, een klantvriendelijke instelling, e.d. spelen een belangrijke rol. 
De scholingsinspanningen zullen zich naar verwachting concentreren op het vergroten van het direct inzetbare arbeidsaanbod in beroepsgroepen uit de segmenten techniek, bouw, zorg, administratie en secretariaat. Het gaat hierbij onder andere om bankwerkers en lassers, metaalarbeiders, verplegenden, verkooppersoneel, secretaresses, (elektro) monteurs, productieplanners, procesoperators en programmeurs.

\section{Het onderwijsbeleid}

Vanuit het oogpunt van de zogenaamde macrodoelmatigheid van het onderwijs is het wenselijk de instroom van leerlingen in opleidingen met goede of zeer goede arbeidsmarktperspectieven te bevorderen. Het zonder meer vergroten van het onderwijsaanbod zal echter niet altijd de gewenste effecten sorteren. Een vergroting van de opleidingscapaciteit garandeert immers niet dat deze capaciteit ook daadwerkelijk benut zal worden. Een betere geografische spreiding of de introductie van een opleidingsvariant die op dat moment nog niet wordt aangeboden, zal doorgaans echter wel de leerlingeninstroom voor het betreffende opleidingstype verhogen, doordat mobiliteitsdrempels worden weggenomen of beter ingespeeld kan worden op de interesses of capaciteiten van leerlingen. Een vraag die zich voordoet bij een dergelijke uitbreiding van het onderwijsaanbod is echter welke leerlingen hiermee worden aangetrokken. Nieuw aanbod van opleidingen zal daarom met name baat hebben, wanneer er leerlingen worden aangetrokken die anders een opleiding hadden gekozen met duidelijk slechtere perspectieven. Naast het arbeidsmarktperspectief, dat gebaseerd is op de verwachte ontwikkelingen in vraag en aanbod, kan het onderwijsbeleid ook de structurele positie van opleidingen als richtlijn nemen. Een tweetal risico-indicatoren is op dit punt van belang: de conjunctuurgevoeligheid van de werkgelegenheid en de uitwijkmogelijkheden naar andere beroepsgroepen. Zo worden de technisch opgeleiden geconfronteerd met een hoge conjunctuurgevoeligheid van de werkgelegenheid. Arbeidskrachten met een verzorgende of medische opleiding hebben doorgaans relatief beperkte uitwijkmogelijkheden.

De omvang van de verwachte instroom op de arbeidsmarkt vormt een indicatie voor de mogelijkheden die een vergroting van de opleidingscapaciteit van een bepaald opleidingstype biedt. Wanneer de verwachte instroom reeds relatief hoog is, vindt het goede perspectief vooral zijn oorsprong in de grote vraag naar nieuwkomers met het betreffende opleidingstype. De opleiding is dan reeds relatief populair in verhouding tot de 'omvang' van de markt voor deze opleiding in Limburg. Dit impliceert dat het omzetten van een eventuele capaciteitsvergroting in een daadwerkelijke vergroting van de instroom aanzienlijke inspanningen zal vragen, zoals het verder vergroten van het aantal leerplaatsen bij bedrijven en het aanboren van geheel nieuwe groepen leerlingen. Wanneer daarentegen de verwachte instroom relatief klein is, dan ligt vooral de geringe instroom aan het goede perspectief ten grondslag. In dat geval zal het omzetten van een eventuele capaciteitsvergroting in een daadwerkelijke vergroting van de instroom waarschijnlijk eenvoudiger te realiseren zijn. Het marktaandeel van deze opleiding is dan immers waarschijnlijk laag. Door bijvoorbeeld de doorstroom uit de lagere opleidingen - met een slechter perspectief - te bevorderen, kan het marktaandeel vergroot worden. Ook het realiseren van de gewenste infrastructuur in de regio zal waarschijnlijk eenvoudiger zijn, hoewel er op bepaalde segmenten van de arbeidsmarkt natuurlijk specifieke problemen een verdere capaciteitsvergroting kunnen belemmeren. Voorbeelden hiervan zijn de technische en de zorgopleidingen. Bij de technische oplei- 
dingen kan er op termijn in het onderwijs een belangrijk knelpunt ontstaan in de vorm van een tekort aan leraren in de techniek. In het zorgonderwijs vormt het tekortschietend aantal zogenaamde beroepspraktijkvormingsplaatsen een belangrijk knelpunt.

De macrodoelmatigheid van het beroepsonderwijs is het meest gebaat bij een adequaat aanbod van leerwegen die VBO-schoolverlaters in staat stellen een kwalificatie op MBOniveau te behalen. Dit geldt het sterkst voor de vervoers-, motorvoertuigentechniek-, grafische techniek-, administratie-, handel- en horeca-opleidingen en vanzelfsprekend ook voor de opleidingen die ongeschoolden met slechts Basisonderwijs en MAVO'ers en HAVOVWO'ers in staat stellen met succes een beroepsopleiding te volgen met goede arbeidsmarktperspectieven en geringe arbeidsmarktrisico's. 
S-

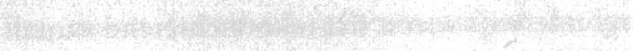
T.

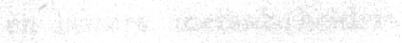

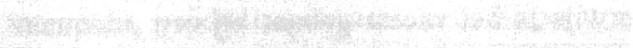

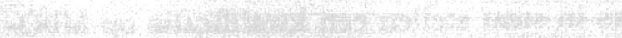

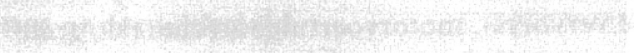

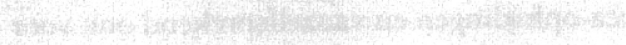

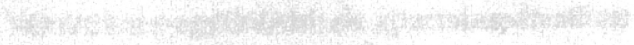

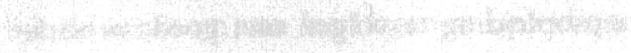

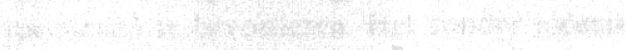




\section{De Limburgse arbeidsmarkt in vogelvlucht}

\subsection{Inleiding}

In dit hoofdstuk zal een globale schets worden gegeven van de belangrijkste ontwikkelingen op de Limburgse arbeidsmarkt. In het vorig jaar verschenen rapport De Limburgse arbeidsmarkt 1997-2002 lag het accent op de ontwikkelingen op de middellange termijn. In dit rapport ligt de nadruk op de ontwikkelingen op de korte termijn. Eerst wordt een beeld geschetst van de Limburgse arbeidsmarkt op macro-niveau. Hierbij zal ook worden ingegaan op de achterliggende factoren die van invloed zijn op de Limburgse arbeidsmarktontwikkelingen. Daarna worden de ontwikkelingen verbijzonderd naar bedrijfssector, beroepssector en opleidingsniveau. Verwacht wordt dat werkgevers in Limburg in 1999 op een groot aantal arbeidsmarktsegmenten problemen zullen ondervinden bij het aantrekken van nieuw personeel. Met name op MBO-niveau zullen de knelpunten in de personeelsvoorziening aanzienlijk zijn. Dit maakt het belangrijk om de vraag te stellen in hoeverre de knelpunten op de Limburgse arbeidsmarkt kunnen worden opgelost door het inschakelen van de niet-direct bemiddelbare werkzoekenden en andere niet-actieven.

\subsection{De verwachte arbeidsmarktontwikkeling in 1999}

De economische groei die Limburg de laatste jaren doormaakt zal zich naar verwachting in 1999 voortzetten. Zoals tabel 1.1 laat zien, resulteren deze gunstige verwachtingen in een werkgelegenheidsgroei van $2,2 \%$. Dit is een groei van maar liefst bijna 10.000 banen. Limburg loopt hiermee in de pas met het landelijke beeld. Ook landelijk wordt een werkgelegenheidsgroei van 2,2\% verwacht. Recente voorspellingen laten zien dat het effect van de geringe conjuncturele terugval in de tweede helft van 1998 op de werkgelegenheidsgroei naar verwachting gering zal zijn. De conjuncturele terugval zou kunnnen resulteren in een geringe afname van de groei van de werkgelegenheid tot 1,9\% (ETIL, 1999)". De werkgelegenheidsgroei zwakt daarmee overigens wel af ten opzichte van de afgelopen jaren, toen de groei in Limburg nog 3,5\% bedroeg. Terwijl de economische groei in Limburg duidelijk hoger is dan landelijk, blijft de werkgelegenheidsgroei, evenals de afgelopen jaren, enigzins achter. In Limburg wordt de economische groei voor een belangrijk deel gerealiseerd door middel van een toename van de arbeidsproductiviteit, waardoor geen extra werkgelegenheid ontstaat. Met name het industriële karakter van de Limburgse werkgelegenheid speelt hierbij een belangrijke rol (ETIL, 1998).

4 ETIL, Werkgelegenheidsontwikkeling in Limburg 1987-1995-1999, Maastricht, 1998.

5 ETIL, L-SEV 1998, Maastricht, 1998. 
Tabel 1.1

Verwachte arbeidsmarktontwikkeling in Limburg in 1999

Werkgelegenheidsontwikkeling

Arbeidsmarktuitstroom

Baanopeningen

Arbeidsmarktinstroom

* Recente voorspellingen laten zien dat de geringe conjuncturele terugval in de tweede helft van 1998 zou kunnen resulteren in een geringe afname van de werkgelenheidsstructuur tot $1,9 \%$.

\section{Bron: TNO/Inro/ROA}

In het eerste RAIL-rapport De Limburgse arbeidsmarkt 1997-2002 is reeds uitgebreid stilgestaan bij de vergrijzing van de Limburgse beroepsbevolking. De Limburgse bevolking wordt steeds ouder. Daardoor neemt ook de gemiddelde leeftijd van de werkende bevolking toe. De vergrijzing van de Limburgse beroepsbevolking heeft tot gevolg dat de arbeidsmarktuitstroom steeds verder toeneemt. Voor 1999 wordt verwacht dat maar liefst ruim $5 \%$ van de werkenden in Limburg de arbeidsmarkt door pensionering, vervroegde uittreding, arbeidsongeschiktheid, e.d. zal verlaten. De vervangingsvraag op de arbeidsmarkt zal daardoor groot zijn.

De hoge arbeidsmarktuitstroom in Limburg is niet alleen het gevolg van de snelle vergrijzing van de beroepsbevolking. De hoge uitstroom wordt ook veroorzaakt door het industriële karakter van de werkgelegenheid. In de industrie is vaker sprake van zwaar lichamelijk werk en andere belastende arbeidsomstandigheden, waardoor de uitstroom van de arbeidsmarkt wordt versneld.

Door de hoge werkgelegenheidsgroei en arbeidsmarktuitstroom bedraagt het percentage baanopeningen in Limburg in 1999 maar liefst 7,3\% . Dit betekent dat er naar verwachting ongeveer 33.000 baanopeningen voor nieuwkomers op de arbeidsmarkt zullen zijn ${ }^{7}$. Bij de recent voorspelde werkgelegenheidsgroei van $1,9 \%$, zal het aantal baanopeningen ruim 31.000 bedragen. Dit grote aantal baanopeningen laat zien dat de enigszins teruglopende werkgelegenheidsgroei slechts een gering effect heeft op de behoefte van werkgevers aan nieuw personeel. Immers, ruim twee-derde van het totale aantal baanopeningen vloeit voort uit de vervangingsbehoefte op de arbeidsmarkt.

Aan de aanbodzijde van de arbeidsmarkt eist de ontgroening zijn tol. Het aantal jongeren daalt. Hierdoor neemt het aantal onderwijsvolgenden af. Bovendien volgen jongeren steeds langer een dagopleiding, waardoor hun intrede op de arbeidsmarkt wordt uitgesteld.

6 In procenten van het totaal aantal werkenden op de Limburgse arbeidsmarkt.

7 Het aantal vacatures zal waarschijnlijk veel hoger liggen. Immers, als een vacature wordt ingevuld met iemand die ergens anders werkzaam was, ontstaat er vaak weer een nieuwe vacature op de plek die deze werknemer achterlaat. Door deze zogenaamde 'vacature-ketens' schommelt het aantal vacatures doorgaans veel sterker dan het echte aantal baanopeningen voor nieuwkomers op de arbeidsmarkt. 
Het aantal schoolverlaters dat instroomt op de arbeidsmarkt zal als gevolg van deze ontwikkelingen de komende jaren verder dalen. In 1999 zullen ruim 14.000 schoolverlaters op de Limburgse arbeidsmarkt op zoek gaan naar een baan. Deze arbeidsmarktinstroom van 3,2\% is veel kleiner dan het verwachte aantal baanopeningen.

De schoolverlaters die hun intrede doen op de arbeidsmarkt worden daardoor gewilde kandidaten voor de werkgevers die op zoek zijn naar nieuw personeel. De meeste schoolverlaters hebben daardoor gunstige arbeidsmarktperspectieven. De keerzijde hiervan is dat op een groot aantal segmenten van de Limburgse arbeidsmarkt een tekort aan direct inzetbare arbeidskrachten ontstaat. Dit zal leiden tot grote knelpunten in de personeelsvoorziening.

Werkgevers zouden op deze ontwikkeling in kunnen spelen door de uitstroom van oudere werknemers af te remmen, of door arbeidskrachten aan te trekken met een grotere afstand tot de arbeidsmarkt. Dit betekent dat het verhogen van de participatiegraad van de Limburgse beroepsbevolking een belangrijke rol zou kunnen spelen bij het voorkomen van de verwachte knelpunten in de personeelsvoorziening.

Vergeleken met het vorig jaar is de krapte op de arbeidsmarkt flink toegenomen. Tabel 1.2 illustreert dit. In deze tabel worden drie indicatoren gepresenteerd die, elk vanuit een verschillende invalshoek, een indicatie geven van de rekruteringsproblemen die werkgevers momenteel op de Limburgse arbeidsmarkt ondervinden:

- de arbeidsmarktkrapte geeft de verhouding weer tussen het aantal openstaande vacatures en het aantal direct inzetbare werklozen;

- de vacaturegraad geeft het aantal openstaande vacatures als promillage van de werkgelegenheid weer;

- het percentage moeilijk vervulbare vacatures geeft de verhouding aan tussen het aantal vacatures dat langer dan drie maanden openstaat en het totaal aantal openstaande vacatures.

De eerste indicator geeft aan in hoeverre het aanbod van direct inzetbare werklozen toereikend is om te openstaande vacatures op te kunnen vullen. De tweede indicator laat zien hoe groot de inspanning is die verricht moet worden om in de behoefte aan nieuw personeel te voorzien. De derde indicator geeft aan in hoeverre bedrijven moeite hebben om hun vacatures op korte termijn te vervullen.

\section{Tabel 1.2}

\section{Krapte op de Limburgse arbeidsmarkt}


Uit de tabel blijkt dat de arbeidsmarktkrapte in Limburg het afgelopen jaar spectaculair is gestegen. Waren er in 1997 nog slechts 39 openstaande vacatures per 100 direct inzetbare werklozen, in 1998 staan er tegenover iedere 100 direct inzetbare werklozen maar liefst 222 vacatures. Voor deze verkrapping zijn twee oorzaken aan te wijzen. In de eerste plaats is het aantal vacatures aanzienlijk toegenomen. Dit blijkt ook uit de toegenomen vacaturegraad. In de tweede plaats is, als gevolg van de krapte op de Limburgse arbeidsmarkt, het aantal direct inzetbare werklozen sterk afgenomen. Het totaal aantal werklozen is met ongeveer 20.000 gedaald tot ruim 40.000 . Daarbij is vooral het aantal direct inzetbare werkzoekenden sterk afgenomen. In 1997 werd nog 35\% van de werkzoekenden als direct inzetbaar beschouwd. Momenteel is dit nog slechts $17 \%$. Dit betekent dat het aantal direct bemiddelbare werklozen in 1 jaar tijd is gedaald van ruim 20.000 naar slechts 7.000 mensen. De toegenomen krapte manifesteert zich ook in het toegenomen aantal langdurig openstaande vacatures. Wel is het opmerkelijk dat deze maatstaf de toegenomen krapte op de arbeidsmarkt minder goed signaleert dan de beide andere indicatoren.

\subsection{Ontwikkelingen naar bedrijfssector}

\section{De ontwikkeling van de werkgelegenheid}

Tabel 1.3 geeft aan dat de gunstige ontwikkeling van de werkgelegenheid, zoals die naar voren komt uit tabel 1.1, zich niet in alle bedrijfssectoren manifesteert. Er heeft de laatste jaren in Limburg een verschuiving van de werkgelegenheid van de industrie naar de commerciële dienstverlening plaatsgevonden. De afgelopen jaren is de werkgelegenheidsgroei dan ook het grootst geweest in het bank- en verzekeringswezen en de sector transport en communicatie. Ook de sector bouw en onroerend goed is sterk gegroeid. In de landbouw en visserij en de chemie is de werkgelegenheid daarentegen de afgelopen jaren gekrompen.

Voor 1999 wordt verwacht dat de werkgelegenheidsgroei zal afnemen. Groeide de werkgelegenheid de afgelopen jaren nog met 3,5\% ${ }^{8}$, in 1999 wordt ten opzichte van 1998 een groei van $2,2 \%$ verwacht. In de landbouw zal de werkgelegenheid naar verwachting verder afnemen. Voor de chemie wordt daarentegen weer een bovengemiddelde groei van de werkgelegenheid verwacht. Opvallend is de verwachte omslag in de werkgelegenheidsontwikkeling in het bank- en verzekeringswezen. Na de forse groei van de afgelopen jaren wordt voor 1999 een daling van de werkgelegenheid verwacht. De voortschrijdende automatisering van zowel de 'front-office' als de 'back-office' activiteiten speelt hierbij waarschijnlijk een belangrijke rol.

De grootste werkgelegenheidsgroei wordt verwacht in de sectoren horeca, reparatie en zakelijke dienstverlening, transport en communicatie en de handel. Dit beeld onderstreept de voortschrijdende verdienstelijking van de Limburgse economie. De hoge werkgelegenheidsgroei in de zakelijke dienstverlening is mede het gevolg van het feit dat de uitzendbranche en de detacheringsbedrijven deel uitmaken van deze sector. De flexibilisering van de arbeidsmarkt zorgt voor een toenemende werkgelegenheid in deze bedrijven. Bovendien

8 De werkgelegenheid in Limburg is gestegen van 434.500 (gemiddelde 1995-1996) naar 449.500 werkenden (gemiddelde 1996-1997). 
Tabel 1.3

Ontwikkeling werkgelegenheid in Limburg naar bedrijfssector

\begin{tabular}{llll} 
Bedrijfssector & $\begin{array}{c}\text { aantal } \\
\text { werkenden } \\
1996-1997\end{array}$ & $\begin{array}{c}\text { trend } \\
1995-1997\end{array}$ & 1999 \\
& & & $\%$ \\
\hline Landbouw en visserij & 16.500 & sterk dalend & $-1,3$ \\
Voeding & 11.000 & stijgend & 1,2 \\
Chemie & 15.000 & dalend & 2,4 \\
Metaal en elektrotechniek & 59.500 & constant & 3,1 \\
Overige industrie & 22.500 & stijgend & 0,5 \\
Energie & 5.000 & constant & 0,0 \\
Bouw en onroerend goed & 31.500 & sterk stijgend & 0,4 \\
Handel & 54.000 & constant & 2,9 \\
Transport en communicatie & 25.500 & sterk stijgend & 3,1 \\
Bank- en verzekeringswezen & 13.500 & sterk stijgend & $-1,0$ \\
Horeca, reparatie etc. & 57.000 & stijgend & 4,2 \\
Kwartaire diensten & 68.000 & stijgend & 1,6 \\
Overheid en onderwijs & 60.500 & stijgend & 1,0 \\
Totaal & & & \\
\hline
\end{tabular}

Bron: TNO/Inro/CBS/ROA

besteden grote bedrijven steeds vaker hun facilitaire diensten uit aan gespecialiseerde dienstverlenende bedrijven. Men spreekt in dit verband vaak van een 'outsourcing' van activiteiten.

\section{Knelpunten in de personeelsvoorziening}

Tabel 1.4 geeft een overzicht van de actuele discrepanties tussen vraag en aanbod op de Limburgse arbeidsmarkt verbijzonderd naar bedrijfssector. Uit de tabel blijkt dat er in vrijwel alle sectoren sprake is van knelpunten in de personeelsvoorziening. De problemen zijn het grootst in de commerciële dienstverlening. Dit sluit aan bij het beeld dat vorig jaar is geschetst. Voor het bank- en verzekeringswezen en de horeca, reparatie en zakelijke dienstverlening staan alle drie de indicatoren op rood. Deze sectoren hebben te kampen met een grote arbeidsmarktkrapte, een hoge vacaturegraad en een hoog percentage moeilijk vervulbare vacatures. Dit betekent dat deze sectoren geconfronteerd worden met een tekort aan direct inzetbare werkzoekenden. De bedrijven in deze sectoren hebben dan ook moeite om vacatures op korte termijn te vervullen, gezien het hoge percentage moeilijk vervulbare vacatures. Daarbij staat de rekrutering extra onder druk vanwege de hoge vacaturegraad in deze sectoren.

Ook in de industrie is er sprake van een grote arbeidsmarktkrapte. Het aantal vacatures overtreft het aanbod van direct bemiddelbare werklozen. De vacaturegraad en het percentage langdurig openstaande vacatures liggen daarentegen op een wat lager niveau. Dit bete- 
kent dat de industrie te kampen heeft met een tekort aan direct inzetbaar personeel in specifieke beroepen. Het aantal vacatures is echter niet uitzonderlijk hoog. Bovendien is de industrie nog altijd redelijk goed in staat op de korte termijn de vacatures te vervullen. Blijkbaar is de aanzuigende werking van de grote industriële bedrijven zo groot dat het (schaarse) arbeidsaanbod op de voor deze bedrijven relevante arbeidsmarktsegmenten vaak voor een functie in de industrie kiest.

\section{Tabel 1.4}

Actuele discrepanties op de Limburgse arbeidsmarkt naar bedrijfssector, 1998

Bedrijfssector

Landbouw en visserij

Voeding

Chemie

Metaal en elektrotechniek

Overige industrie

Energie

Bouw en onroerend goed

Handel

Transport en communicatie

Bank- en verzekeringswezen

Horeca, reparatie etc.

Kwartaire diensten

Overheid en onderwijs

arbeidsmarktkrapte

vacaturegraad

langdurig

openstaand

\begin{tabular}{lll}
\hline laag & hoog & hoog \\
hoog & gemiddeld & gemiddeld \\
hoog & gemiddeld & hoog \\
hoog & gemiddeld & gemiddeld \\
hoog & gemiddeld & gemiddeld \\
laag & laag & gemiddeld \\
gemiddeld & gemiddeld & hoog \\
hoog & hoog & gemiddeld \\
gemiddeld & hoog & hoog \\
hoog & hoog & hoog \\
hoog & zeer hoog & hoog \\
gemiddeld & gemiddeld & hoog \\
hoog & laag & hoog \\
\hline
\end{tabular}

Bron: Arbeidsvoorziening/CBS/ROA

Op de arbeidsmarktsegmenten waar de landbouw, de bouw en de kwartaire diensten hun personeel werven is er sprake van een relatief geringe krapte. Deze sectoren hebben slechts te kampen met zeer specifieke knelpunten in de personeelsvoorziening. Opmerkelijk genoeg gaat dit echter gepaard met een hoog percentage moeilijk vervulbare vacatures, hoewel er volgens Arbeidsvoorziening Limburg voldoende aanbod is van direct inzetbare werklozen. Deze op het eerste gezicht paradoxale situatie kan verschillende oorzaken hebben. Ten eerste kunnen de rekruteringsproblemen betrekking hebben op specifieke beroepsgroepen, terwijl er gemiddeld genomen geen problemen zijn. Een tweede mogelijkheid is dat de vacatures die de bedrijven in deze sectoren aanbieden door de direct inzetbare werklozen niet aantrekkelijk genoeg gevonden worden. Ten derde kan er sprake zijn van kwalitatieve aansluitingsproblemen. Zo kan er bijvoorbeeld vooral behoefte zijn aan schoolverlaters of ervaren werknemers, die momenteel beide schaars zijn. Een andere mogelijkheid is dat het opleidingsniveau van de direct inzetbare werklozen te laag is voor de vacante functies in deze sectoren. 


\subsection{Ontwikkelingen naar beroepssector}

De veranderingen in de werkgelegenheidsstructuur naar bedrijfssector beinvloeden de ontwikkeling van de werkgelegenheid in de verschillende beroepen. Maar ook de verschuivingen in de beroepenstructuur binnen de verschillende bedrijfssectoren leiden vaak tot een sterk uiteenlopende werkgelegenheidsgroei in de verschillende beroepen. In tabel 1.5 wordt een overzicht gegeven van de ontwikkeling van het aantal werkenden in de verschillende beroepssectoren. Ook deze cijfers illustreren de verdergaande verdienstelijking van de Limburgse economie. De laatste jaren is vooral de werkgelegenheid in de medische en paramedische beroepen, de economisch-administratieve beroepen en de sociaal-culturele beroepen sterk gestegen. De ontwikkeling van de werkgelegenheid in de verschillende beroepssectoren geeft duidelijk aan dat de verdienstelijking van de werkgelegenheid ook binnen de bedrijfssectoren plaatsvindt. Ondanks het feit dat de werkgelegenheid in de industrie en de bouwsector de afgelopen jaren gegroeid is, is de werkgelegenheid in de technisch-industriële beroepen niet toegenomen. De werkgelegenheid in de pedagogische, de agrarische en de openbare orde en veiligheidsberoepen is de afgelopen jaren gedaald. De werkgelegenheidskrimp in de agrarische beroepen is niet verrassend, gezien de krimp in de landbouwsector. De afname van de werkgelegenheid in de pedagogische beroepen wordt met name veroorzaakt door de ontgroening, waardoor de werkgelegenheid in het onderwijs de afgelopen jaren enigszins is afgenomen. De krimp in de werkgelegenheid voor de openbare orde en veiligheidsberoepen hangt waarschijnlijk samen met de saneringen die er in het leger hebben plaatsgevonden.

Tabel 1.5

Ontwikkeling werkgelegenheid in Limburg naar beroepssector

Bedrijfssector

aantal

trend

1999

werkenden

1995-1997

$\%$

1996-1997

Pedagogische beroepen

Culturele beroepen

Agrarische beroepen

Technische en industrieberoepen

Transportberoepen

Medische en paramedische beroepen

Economisch-administratieve beroepen

Informaticaberoepen

Sociaal-culturele beroepen

Verzorgende en dienstverl. beroepen

Openbare orde en veiligheidsberoepen

Totaal (inclusief beroep onbekend)

\begin{tabular}{rlr}
\hline 23.000 & dalend & 1,1 \\
5.000 & constant & 3,6 \\
18.500 & dalend & 0,8 \\
118.000 & constant & 1,1 \\
26.000 & constant & 2,8 \\
24.500 & sterk stijgend & 0,9 \\
118.000 & sterk stijgend & 3,4 \\
8.500 & constant & 6,9 \\
12.000 & sterk stijgend & 3,0 \\
80.500 & stijgend & 2,1 \\
6.000 & dalend & 0,5 \\
\hline 449.500 & & \\
\hline & & 2,2 \\
\hline
\end{tabular}

Bron: $C B S / R O A$ 
Voor 1999 wordt ten opzichte van 1998 in alle beroepssectoren een groei van de werkgelegenheid verwacht, met uitzondering van de agrarische beroepen. De groei zal naar verwachting verreweg het sterkst zijn in de informaticaberoepen. De sterke groei in de economischadministratieve en in de sociaal-culturele beroepen zal zich naar verwachting in 1999 doorzetten. De groei in de medische en paramedische beroepen zal daarentegen naar verwachting enigszins afzwakken. Voor de pedagogische beroepen en de openbare orde en veiligheidsberoepen wordt een omslag in de werkgelegenheidsontwikkeling verwacht. In tegenstelling tot de trend in de afgelopen jaren, zal de werkgelegenheid in deze beroepen de komende jaren weer toenemen. Deze groei zal echter bescheiden zijn.

\subsection{Ontwikkelingen naar opleidingsniveau}

Zoals gezegd, wordt er voor Limburg in 1999 een werkgelegenheidsgroei van 2,2\% verwacht. Wanneer er echter een onderscheid gemaakt wordt naar het gevraagde opleidingsniveau blijkt de vraagontwikkeling sterk uiteen te lopen. Tabel 1.6 geeft een overzicht van de verwachte uitbreidingsvraag naar opleidingsniveau. De voorspelde uitbreidingsvraag is gebaseerd op ontwikkelingen aan de vraagzijde van de arbeidsmarkt. Het gaat hier dus uitdrukkelijk om een vraagvoorspelling en niet om een prognose van het aantal werkenden met een bepaald opleidingsniveau. Immers, vanwege de verwachte krapte op de arbeidsmarkt is het niet vanzelfsprekend dat werkgevers deze vraag ook kunnen realiseren.

Uit de tabel blijkt dat er een forse daling van de vraag wordt verwacht naar mensen die slechts Basisonderwijs hebben gevolgd. In Limburg zal de vraag naar deze 'drop-outs' van het voortgezet onderwijs naar verwachting met 3,1\% krimpen. Ook op VBO-niveau is de uitbreidingsvraag negatief. De verwachte krimp van de vraag naar VBO'ers is echter klein. Desalniettemin betekent dit dat de vraag naar mensen met dit opleidingsniveau sterk achter blijft bij de algehele werkgelegenheidsontwikkeling in Limburg. Op MBO-niveau is de

Tabel 1.6

\section{Verwachte uitbreidingsvraag en het arbeidsmarktperspectief naar opleidingsniveau in} Limburg in 1999

\begin{tabular}{lccc} 
Opleidingsniveau & $\begin{array}{c}\text { aantal } \\
\text { werkenden } \\
1996-1997\end{array}$ & $\begin{array}{c}\text { uitbreidings- } \\
\text { vraag } 1999 \\
\%\end{array}$ & $\begin{array}{c}\text { ITA* } \\
1999\end{array}$ \\
\hline Basisonderwijs & 38.000 & $-3,1$ & 1,02 \\
MAVO & 31.500 & 1,5 & 1,02 \\
VBO & 83.000 & $-0,1$ & 1,01 \\
HAVO/NWO & 20.000 & 4,7 & 1,05 \\
MBO & 179.000 & 2,9 & 0,95 \\
HBO & 75.500 & 1,5 & \\
WO & 22.500 & 4,6 & \\
\hline
\end{tabular}

\footnotetext{
* Indicator Toekomstige Arbeidsmarktperspectieven (op basis van een confrontatie van het verwachte aanbod met de verwachte vraag). In de verklarende woordenlijst achterin het rapport wordt een nadere toelichting gegeven.
} 
verwachte uitbreidingsvraag daarentegen fors. In Limburg wordt in 1999 een groei van de werkgelegenheid voor MBO'ers van bijna 3\% ten opzichte van de werkgelegenheid in 1998 verwacht. Ook op HBO- en WO-niveau is de verwachte uitbreidingsvraag aanzienlijk. Opvallend is wel dat de vraag naar HBO'ers in 1999 naar verwachting duidelijk minder zal groeien dan de vraag naar MBO'ers en academici.

Deze cijfers illustreren duidelijk dat de in het vorig jaar verschenen rapport De Limburgse arbeidsmarkt 1997-2002 reeds gesignaleerde 'upgrading' van de opleidingseisen zich verder voortzet. Op MBO-niveau en hoger is er sprake van een positieve uitbreidingsvraag, terwijl de vraag naar VBO'ers en mensen met slechts Basisonderwijs naar verwachting zal dalen.

Zoals in paragraaf 1.2 reeds werd gezegd, worden de baanopeningen voor nieuwkomers op de arbeidsmarkt niet alleen veroorzaakt door de groei van de uitbreidingsvraag. Ook de vervangingsvraag vanwege de pensionering, vervroegde uittreding of arbeidsongeschiktheid van werkenden is een belangrijke bron voor deze baanopeningen. Door het totaal van de verwachte baanopeningen en openstaande vacatures te confronteren met de verwachte arbeidsmarktinstroom en de direct inzetbare werkzoekenden kunnen de arbeidsmarktperspectieven per opleidingsniveau worden aangegeven. Dit arbeidsmarktperspectief wordt in kaart gebracht met behulp van de zogeheten Indicator Toekomstige Arbeidsmarktperspectieven (ITA). Naarmate de ITA kleiner is, zijn er minder direct inzetbare werklozen en instromers in verhouding tot het aantal baanopeningen en is het arbeidsmarktperspectief dus gunstiger. Bij een ITA-waarde kleiner dan één wordt gesproken van een goed perspectief.

Tabel 1.6 laat zien dat op MBO-niveau de perspectieven voor nieuwkomers op de arbeidsmarkt in Limburg in 1999 goed zijn. De Indicator Toekomstige Arbeidsmarktperspectieven ITA is kleiner dan één. Voor degenen met een HAVO- of VWO-opleiding is het arbeidsmarktperspectief daarentegen slechts matig. Ook voor VBO'ers en voor mensen met een MAVO-opleiding of slechts Basisonderwijs is het perspectief minder goed. Aangezien de werkgelegenheid voor ongeschoolden naar verwachting zal krimpen komen er alleen banen vrij voor 'drop-outs' uit het voortgezet onderwijs vanwege de vervangingsbehoefte van bedrijven en instellingen. Daar tegenover staat dat de verwachte arbeidsmarktinstroom van laaggeschoolden naar verwachting relatief gering zal zijn, omdat steeds meer laag opgeleiden kiezen voor een vervolgopleiding. Dit betekent dat het perspectief van direct bemiddelbare laag opgeleiden op de Limburgse arbeidsmarkt in 1999 als 'redelijk' kan worden getypeerd. Hierbij moet echter wel de kanttekening worden geplaatst dat slechts een gering deel van de laaggeschoolde werkzoekenden als direct bemiddelbaar word beschouwd.

Vanzelfsprekend is er ook sprake van sterk uiteenlopende arbeidsmarktperspectieven tussen de verschillende opleidingsrichtingen. Op elk niveau komen zowel opleidingstypen met goede tot zeer goede arbeidsmarktperspectieven, als opleidingstypen met matige of slechte perspectieven voor. In hoofdstuk 4 zal hierop nader worden ingegaan.

Vanuit werkgeversoogpunt betekenen de goede arbeidsmarktperspectieven voor de nieuwkomers op de arbeidsmarkt dat er knelpunten zullen optreden in de personeelsvoorziening. Het aanbod van direct inzetbare arbeidskrachten is dan immers kleiner dan het aantal baanopeningen. Dit betekent dat werkgevers problemen zullen ondervinden bij het aantrekken 
van nieuw personeel. In Limburg zullen dus met name op MBO-niveau de knelpunten in de personeelsvoorziening in 1999 aanzienlijk zijn. Dergelijke arbeidsmarktknelpunten zouden een bedreiging kunnen vormen voor de economische groei in de provincie. Dit temeer daar middelbaar opgeleiden een strategische rol spelen in de concurrentiepositie van het bedrijfsleven". Daarbij gaat het niet zozeer om het innovatieve potentieel van de beroepsbevolking, maar vooral om de kwaliteit van de productie en de dienstverlening.

\subsection{De participatiegraad in Limburg}

Voor het verminderen van de knelpunten op de arbeidsmarkt is een optimaal opleidingsaanbod in het initiële en niet-initiële onderwijs van groot belang. Men spreekt in dit verband wel van de macrodoelmatigheid van het beroepsonderwijs (zie hoofdstuk 7). Daarnaast is een adequaat 'curatief' bij- en omscholingsbeleid gericht op het niet-direct inzetbare aanbod van (langdurig) werkzoekenden van grote betekenis voor het voorkomen van knelpunten in de personeelsvoorziening. In hoofdstuk 6 zal hier nader op worden ingegaan. Ook het stimuleren van de arbeidsparticipatie in het algemeen kan een belangrijke bijdrage leveren aan het vergroten van het aanbod van gekwalificeerd personeel. Dit kan van grote betekenis zijn voor het voorkomen van knelpunten op de arbeidsmarkt, die een remmende factor kunnen vormen voor de economische groei in Limburg.

Tabel 1.7

Arbeidsmarktpositie potentiële beroepsbevolking naar geslacht en leeftijd, Limburg, gemiddelde 1996-1997*

\begin{tabular}{lcccc} 
& $\begin{array}{c}\text { aantal } \\
\%\end{array}$ & $\begin{array}{c}\text { werkzaam } \\
\%\end{array}$ & $\begin{array}{c}\text { werkloos } \\
\%\end{array}$ & $\begin{array}{c}\text { niet-participerend } \\
\%\end{array}$ \\
\cline { 3 - 5 } $\begin{array}{l}\text { Jongeren } \\
\text { Ouderen }\end{array}$ & $\begin{array}{c}\text { 212.000 } \\
197.000\end{array}$ & 56 & 7 & 37 \\
Mannen & 45 & 5 & 50 \\
Vrouwen & 399.000 & 75 & 6 & 19 \\
& 382.000 & 48 & 8 & 44 \\
\hline
\end{tabular}

* De in deze tabel gepresenteerde cijfers hebben betrekking op dat deel van de bevolking dat tussen de 15 en de 64 jaar oud is. lemand wordı beschouwd als jongere wanneer hij of zij jonger is dan 30 jaar; een oudere is 50 jaar of ouder.

Bron: CBS/ROA

Tabel 1.7 geeft een beeld van de omvang van de arbeidsreserve, verbijzonderd naar geslacht en leeftijd. Uit de tabel blijkt dat de arbeidsparticipatie onder de oudere arbeidskrachten in Limburg zeer laag is. Van de bevolking tussen de 50 en de 64 jaar heeft slechts $45 \%$ werk.

9 Zie bijvoorbeeld F. Côrvers, A. de Grip en J-P. Orbon, 'Concurrentiekracht, productiviteit en human capital: een vergelijking tussen Nederland en Duitsland, Maandschrift Economie, vol. 59, no. 3, 1995, pp. 221-24l. 
Maar liefst de helft van deze leeftijdsgroep biedt zich niet (langer) meer aan op de arbeidsmarkt. De kans is groot dat zij door vervroegde uittreding of arbeidsongeschiktheid de arbeidsmarkt reeds definitief hebben verlaten. In dat geval zal het aanzienlijke investeringen vergen deze groep te activeren en (opnieuw) klaar te stomen voor de arbeidsmarkt. Dit roept de vraag op in hoeverre deze investeringen opwegen tegen de baten, gezien het feit dat de periode gedurende welke de investeringen rendement op kunnen leveren kort zal zijn. Maar ook opvallend veel jongeren, die het initieel onderwijs reeds hebben verlaten, zijn niet actief op de arbeidsmarkt. Meer dan éénderde van de bevolking tussen de 15 en de 29 jaar is niet actief op zoek naar werk.

Minder verrassend is dat de arbeidsmarktparticipatie onder mannen veel hoger is dan onder vrouwen. Slechts 19\% van de Limburgse mannen tussen de 15 en de 64 jaar heeft geen werk en zoekt ook niet actief naar werk. Bij de vrouwen is dit percentage veel hoger, namelijk $44 \%$. Geconcludeerd kan worden dat er vanuit een macro-optiek duidelijk mogelijkheden bestaan om via een verhoging van de participatiegraad de krapte op de Limburgse arbeidsmarkt te verminderen. Met name door de participatie van jongeren en vrouwen te stimuleren kan het aanbod op de Limburgse arbeidsmarkt worden vergroot.

In hoofdstuk 5 zal een overzicht worden gegeven van de omvang en samenstelling van de arbeidsreserve in Limburg. Hierbij zal ook nader worden ingegaan op de rol die zij op de Limburgse arbeidsmarkt zouden kunnen spelen in het licht van de verwachte knelpunten op de arbeidsmarkt. Het spreekt voor zich dat het activeren van de arbeidsreserve noodzaakt tot aanzienlijke bij- en omscholingsprogramma's. In hoofdstuk 6 van dit rapport wordt een indicatie gegeven van de gewenste omvang van de scholingsinspanningen om te anticiperen op de voor 1999 verwachte knelpunten in de personeelsvoorziening op de Limburgse arbeidsmarkt. 
chas.

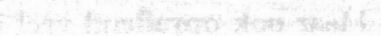




\section{De werkgelegenheidsstructuur in Limburg}

\subsection{Inleiding}

In dit hoofdstuk richten we onze blik op de werkgelegenheidsstructuur in de provincie Limburg. Daarbij wordt niet alleen een beeld van de actuele situatie geschetst, maar er wordt ook een vergelijking gemaakt met gegevens uit De Limburgse Arbeidsmarkt 1997-2002 om de meest in het oog springende ontwikkelingen bloot te leggen. Tevens worden eventuele verschillen met de landelijke situatie belicht. Eerst wordt in paragraf 2.2 een overzicht gegeven van de werkgelegenheid in Limburg naar bedrijfssector. In de daaropvolgende paragrafen 2.3 en 2.4 komen achtereenvolgens de werkgelegenheid naar beroepsgroep en opleidingstype aan bod. De samenstelling van de beroepsbevolking in Limburg wijkt in zekere mate af van het landelijke beeld. Dit heeft vanzelfsprekend zijn weerslag op de werkgelegenheidsstructuur. Daarom wordt ten slotte in paragraaf 2.5 aandacht geschonken aan de arbeidsmarktsituatie naar leeftijd en geslacht.

Uit dit hoofdstuk kan geconcludeerd worden dat de Limburgse werkgelegenheid sterk gegroeid is. Terwijl de economische groei in Limburg duidelijk hoger is dan landelijk, blijft de werkgelegenheidsgroei, evenals de afgelopen jaren, enigszins achter. Het industriële karakter van de werkgelegenheid ligt hieraan ten grondslag. In de industrie wordt de economische groei voor een belangrijk deel gerealiseerd door middel van een toename van de arbeidsproductiviteit, waardoor geen extra werkgelegenheid ontstaat. Het is daarom niet verrassend dat ondanks de groei, de werkgelegenheid in een aantal industriële sectoren in Limburg is gedaald. Het industriële karakter van de werkgelegenheid is het sterkst in het noordelijk deel van de provincie. In het zuiden, waar de dienstensector een veel groter deel van de werkgelegenheid voor zijn rekening neemt, zijn de verschillen met het landelijke beeld veel geringer. Ondanks het industriële karakter van de Limburgse werkgelegenheid, is ook in Limburg sprake van een verdergaande verdienstelijking. Dit hoofdstuk laat zien dat deze verdienstelijking steeds hogere opleidingseisen met zich mee zal brengen. Het gemiddelde opleidingsniveau van de werkenden in de dienstensectoren èn bij de overheid blijkt namelijk veel hoger te zijn dan in de industrie en de landbouw. Opvallend blijft het relatief geringe aandeel van flex-werkers in de Limburgse werkgelegenheid. Landelijk heeft 10 procent van de werkenden een flexibel arbeidscontract; in Limburg is dit wat geringer, namelijk $8 \%$. In een aantal sectoren is er echter wel sprake van een duidelijk stijgende trend in het aandeel flexibele arbeidscontracten.

\subsection{De werkgelegenheid naar bedrijfssector}

In de provincie Limburg waren gedurende de jaren 1996-1997 gemiddeld 449.500 mensen werkzaam, dit is ruim 7\% van de werkende bevolking in Nederland. Dat zijn er 15.000 meer dan in de periode 1995-1996, hetgeen een toename van bijna 3,5\% betekent. Ondanks de wat hogere economische groei, blijft de groei van de werkgelegenheid in Limburg, evenals de afgelopen jaren, wat achter bij de landelijke groei. In Limburg wordt de economische groei voor een belangrijk deel gerealiseerd door middel van een toename van de arbeids- 
productiviteit, waardoor geen extra werkgelegenheid ontstaat (ETIL, 1998) ${ }^{10}$. Ondanks genoemde stijging zijn er enkele sectoren die recentelijk een daling van het aantal werkenden hebben laten zien. Dit geldt in het bijzonder voor de veehouderij en voor enkele industriêle sectoren, zoals de kunststofverwerking, de machine-industrie/elektrotechniek en de houten bouwmaterialen. De kunststofverwerking laat met bijna 15\% de sterkste krimp in de werkgelegenheid zien. Tegelijkertijd echter telt de industrie ook een aantal van de sterkste groeiers, met name transportmiddelen, de grafische industrie en de bouw en onroerend goed; gemiddeld bedraagt de groei hier ruim $15 \%$. Ook de werkgelegenheid in het verzekeringswezen laat een sterke opwaartse trend zien. Een illustratie van de sectorale werkgelegenheidsstructuur in Limburg wordt gegeven in figuur 2.1. Daarin wordt ook een vergelijking gemaakt met de werkgelegenheidssituatie in Nederland als geheel. In het oog springend bij deze vergelijking tussen het Limburgse en het landelijke beeld is het grote aantal mensen dat in Limburg in de landbouw en in de industrie en energie werkzaam is. Limburg scoort daarentegen lager dan het landelijk gemiddelde waar het de handel en diensten betreft. Deze cijfers illustreren het industriële karakter van de Limburgse werkgelegenheid. Dit industriële karakter vormt, zoals hierboven gesteld, een belangrijke verklaring voor het feit dat de economische groei in Limburg meer dan landelijk gerealiseerd wordt door middel van een verhoging van de arbeidsproductiviteit.

Figuur 2.1

De werkgelegenheid naar bedrijfssector in Limburg, gemiddelde 1996-1997, in vergelijking met Nederland en de periode 1995-1996, in procenten

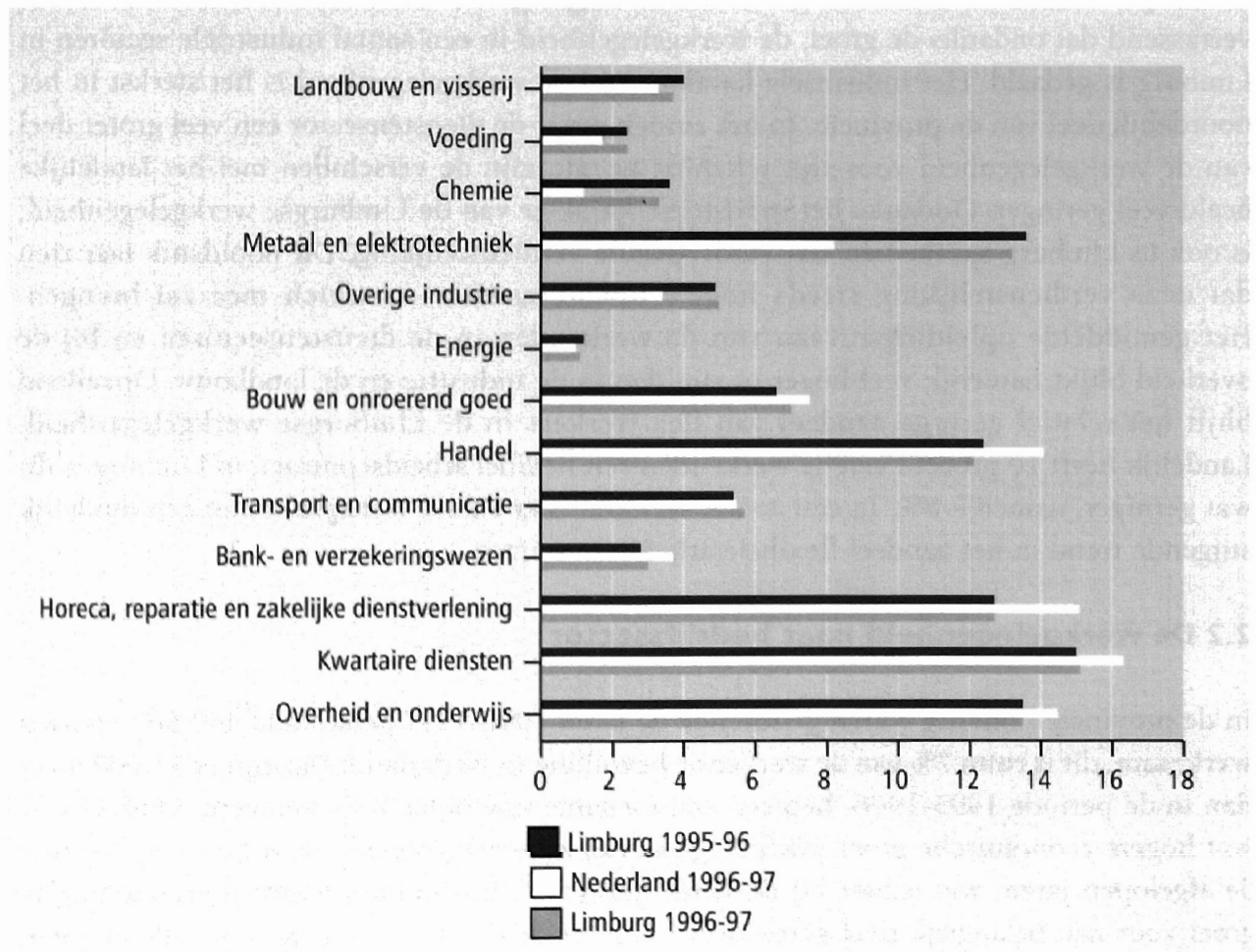

10 ETIL, L-SEV 1998, Maastricht, 1998. 
Ook binnen de verschillende bedrijfssectoren zijn er belangrijke verschillen tussen de Limburgse en de landelijke werkgelegenheidsstructuur. Hoewel het aandeel van de bouwsector in de Limburgse werkgelegenheid vergelijkbaar is met het landelijke beeld, is het aandeel van de burger- en utiliteitsbouwbedrijven in Limburg wat groter. Daarentegen is het aandeel van de grond-, weg- en waterbouwbedrijven kleiner. Van de bouwinstallatie is bekend dat er in Limburg relatief veel mensen in de installatiebedrijven werkzaam zijn en minder in de verwarmingstechniek, alsmede in beheer, ontwerp en management. In de zorgsector, die het overgrote deel van de werkgelegenheid in de kwartaire dienstensector voor zijn rekening neemt, zijn in Limburg relatief weinig mensen werkzaam in de thuiszorg en relatief veel in de intramurale zorg.

\section{Figuur 2.2}

De werkgelegenheid naar bedrijfssector in Zuid-Limburg en Noord- en Midden-Limburg, gemiddelde 1996-1997, in procenten

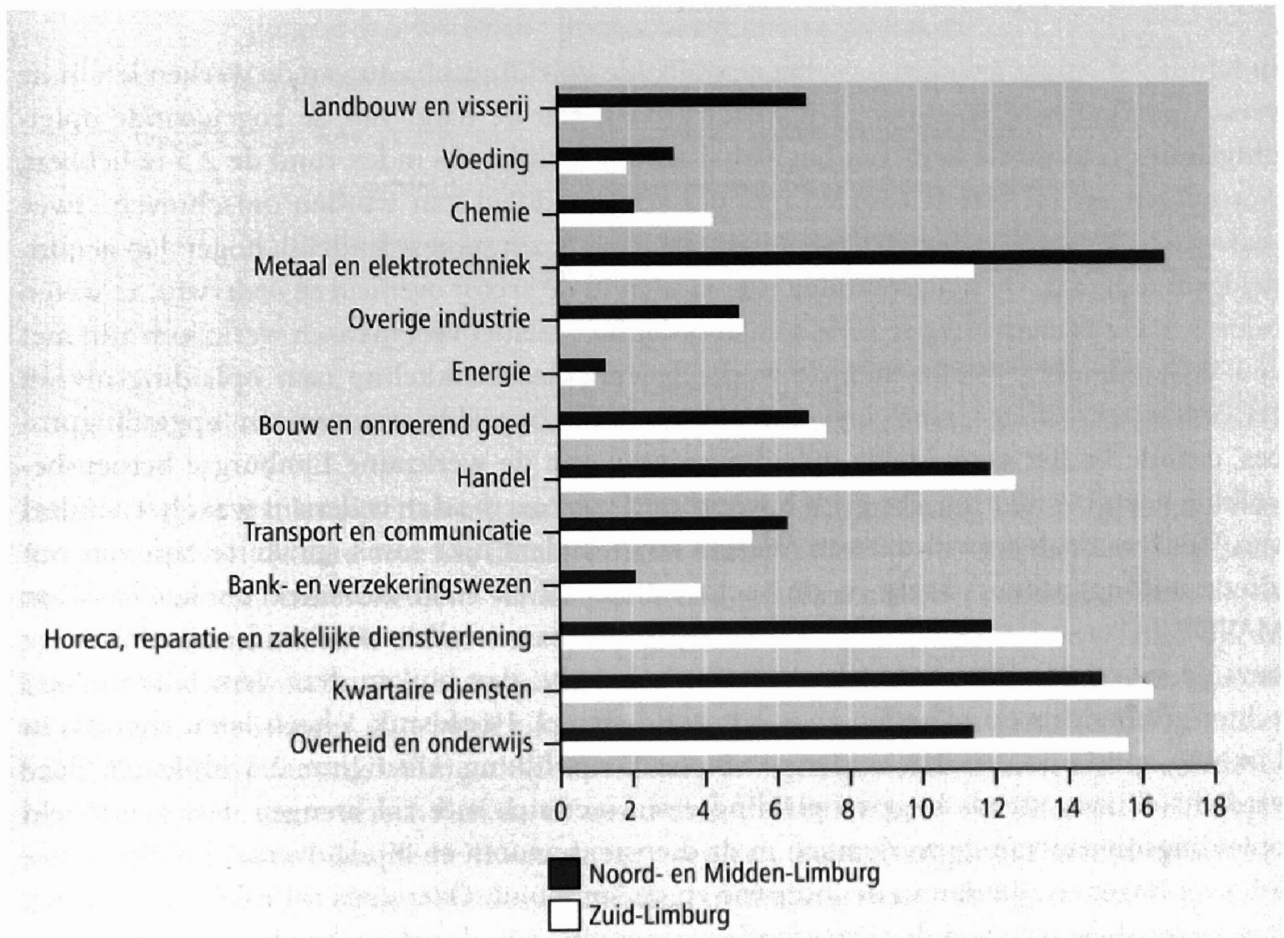

Figuur 2.2 geeft een nadere uitsplitsing van het aantal werkenden per bedrijfssector naar de regio's Zuid-Limburg en Noord- en Midden-Limburg. Zuid-Limburg blijkt ongeveer 56\% van het totaal aantal werkenden in de provincie voor zijn rekening te nemen; dit is gelet op de sterkere verstedelijking van deze regio geenszins verwonderlijk. De landbouw blijkt dan ook geconcentreerd te zijn in Noord-en Midden-Limburg. Dit geldt eveneens voor de metaal en elektrotechniek. In Zuid-Limburg is de chemie sterk vertegenwoordigd alsmede de zakelijke dienstverlening zoals het bank-en verzekeringswezen. Het relatief grote aantal werkenden in de sector overheid en onderwijs in het zuidelijk deel van de provincie kan 
eenvoudig worden verklaard uit de aanwezigheid van instellingen als het $C B S$, het $A B P$, de Open Universiteit en de Universiteit Maastricht, alsmede uit de concentratie van de provinciale bestuursfunctie. Ten opzichte van het vorige jaar zijn er nauwelijks verschuivingen opgetreden; het aandeel van de sector metaal en elektrotechniek is in Zuid-Limburg iets groter geworden, terwijl in Noord- en Midden-Limburg het werkgelegenheidsaandeel van de landbouw en visserij enigszins is teruggelopen.

Ook binnen de bedrijfssectoren zijn er belangrijke accentverschillen tussen de verschillende regio's. Zo ligt in de bouwsector in Noord-Limburg de nadruk op de burger- en utiliteitsbouw, terwijl in het zuiden relatief veel mensen werkzaam zijn in de bouwinstallatiebedrijven. Binnen de zakelijke dienstverlening is met name de ICT-sector geconcentreerd in het zuiden van de provincie. In Noord-Limburg hebben de accountancy- en administratiebedrijven een relatief groot aandeel in de werkgelegenheid. In de kwartaire diensten en in het bijzonder in de zorg daarentegen zijn er geen grote structurele verschillen aan te wijzen.

In figuur 2.3 wordt gekeken naar het gemiddelde opleidingsniveau van de werkenden in de verschillende bedrijfssectoren. Dit wordt gedaan aan de hand van de zogenaamde opleidingsinde ${ }^{11}$. Ruim de helft van het aantal sectoren blijkt een index rond de 2,5 te hebben, wat op een schaal van één tot en met vijf als gemiddeld kan worden omschreven. Twee sectoren in de industrie en de dienstensector in brede zin scoren duidelijk hoger dan gemiddeld, rond de 3,0. De hoogste index is te vinden in de sector overheid en onderwijs, te weten bijna 3,5. Dit is eenvoudig te verklaren doordat hier relatief veel mensen werkzaam zijn met een WO-opleiding. Beziet men de werkgelegenheidsontwikkeling naar opleidingsniveau (cf. Statistische Bijlage, tabel 1.4), dan valt op dat in bepaalde sectoren een 'upgradingproces' gaande is; het gemiddelde opleidingsniveau van de werkzame Limburgse beroepsbevolking neemt verder toe. Dit geldt bijvoorbeeld voor overheid en onderwijs waar het aandeel van HBO'ers daalt terwijl dat van WO'ers stijgt. Elders lijkt soms sprake te zijn van een 'downgradingsproces' zoals in de sectoren metaal en elektrotechniek en handel waar MAVO/VBO'ers worden vervangen door werknemers met alleen Basisonderwijs. Wanneer men de totale ontwikkeling over de sectoren bekijkt, dan blijken deze verschillen elkaar echter grotendeels op te heffen en is het beeld stabiel. Hoofdstuk 1 heeft laten zien dat in Limburg sprake is van een verdergaande verdienstelijking. Uit figuur 2.3 blijkt dat deze verdienstelijking steeds hogere opleidingseisen met zich mee zal brengen. Het gemiddeld opleidingsniveau van de werkenden in de dienstensectoren en bij de overheid blijkt namelijk veel hoger te zijn dan in de industrie en de landbouw. Overigens zal naar verwachting, met name als gevolg van de verregaande verkrapping van de arbeidsmarkt, het opleidingsniveau steeds minder een afspiegeling vormen van het daadwerkelijke niveau van de gevraagde kwalificaties (ETIL, 1998) ${ }^{12}$.

11 Deze index is op de volgende wijze samengesteld: Er worden vijf opleidingsniveaus onderscheiden die elk een eigen code krijgen, van éen voor het laagste niveau (Basisonderwijs) tot vijf voor het hoogste niveau (WO). Vervolgens wordt voor elke sector het percentage dat de betreffende opleidingsachtergrond heeft met de corresponderende code vermenigvuldigd en tenslotte worden deze getallen opgeteld.

12 ETIL, L-SEV 1998, Maastricht, 1998. 
Figuur 2.3

Gemiddeld opleidingsniveau van werkenden per bedrijfssector, Limburg, gemiddelde 1996-1997

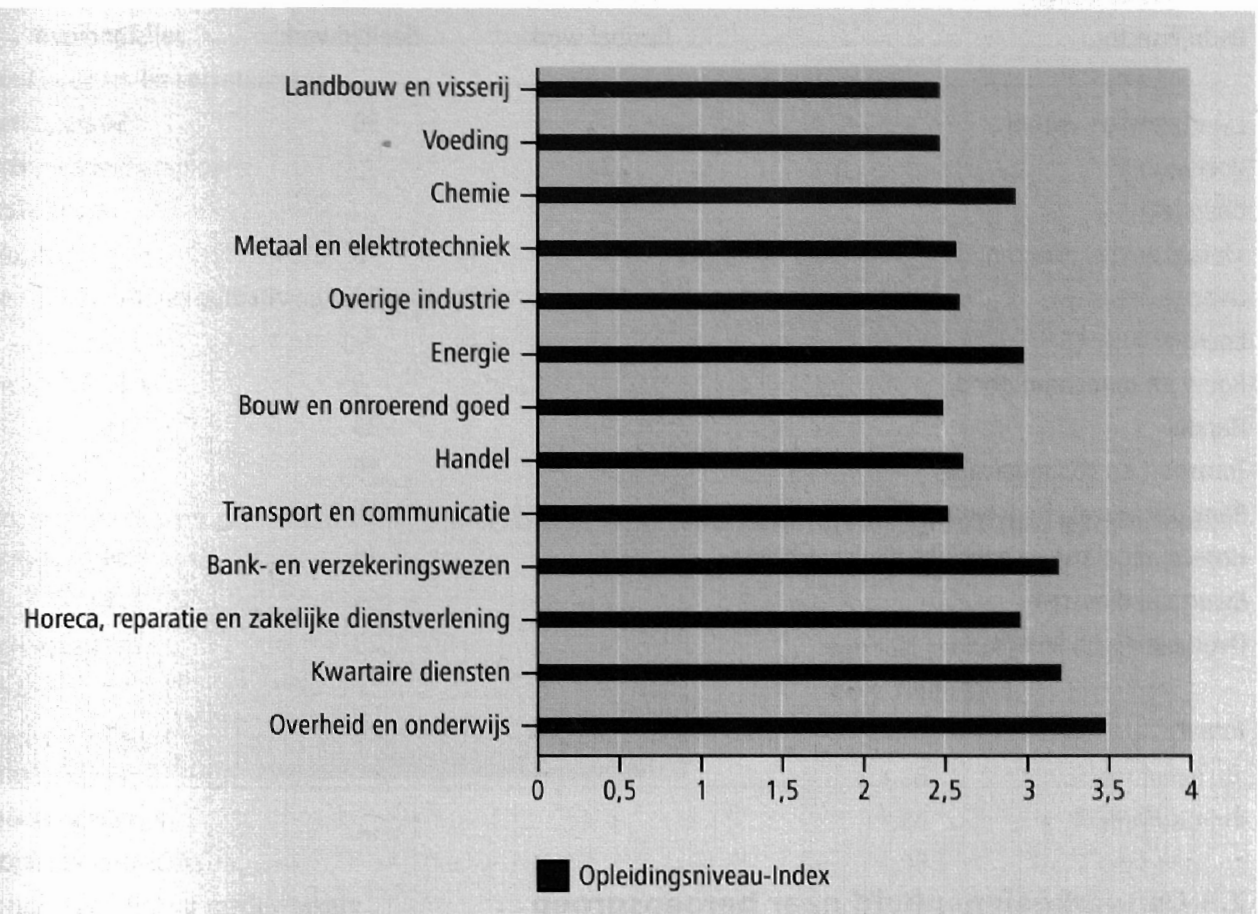

Tabel 2.l geeft een karakterisering van de wijze waarop aan het werk invulling is gegeven. Ten aanzien van de aard van het dienstverband kunnen daarbij o.a. flexibel werk en deeltijdwerk worden onderscheiden. Verder wordt nog gekeken naar het aandeel zelfstandigen per bedrijfssector. Flexibele contracten blijken een relatief kleine rol te spelen op de Limburgse arbeidsmarkt; het betreffende percentage ligt op slechts $8 \%$ van het totaal aantal werkenden. Dit is lager dan landelijk, waar $10 \%$ van de werkenden een flexibel contract heeft. Daarbij zijn er ook weinig uitschieters naar boven dan wel naar beneden te constateren. Wel zijn er grote verschillen in de trend over de laatste jaren (cf. Statistische Bijlage, tabel 1.7), met voor bijna de helft van de sectoren een (sterke) stijging. Deeltijdwerk is als fenomeen aanzienlijk wijdverbreider (gemiddeld over alle sectoren 26\%), al lijkı de groei er hier zo langzamerhand wel uit te zijn; er zijn nog maar weinig sectoren die over 1996-1997 ten opzichte van de vorige waarnemingsperiode een groei laten zien. Een hoger dan gemiddeld percentage deeltijdwerk is te constateren in de landbouw en visserij, de handel, de horeca, reparatie en zakelijke dienstverlening en vooral in de kwartaire diensten. Ten opzichte van het landelijke beeld zijn er zowel afwijkingen naar boven als naar beneden. De landbouw en visserij en de voeding kennen in Limburg veel deeltijdwerkers ten opzichte van het landelijke beeld, de overige industrie daarentegen erg weinig. Het percentage zelfstandigen (gemiddeld $11 \%$ ) is het hoogst in de sector landbouw en visserij. Ook in de horeca, reparatie en zakelijke dienstverlening zijn relatief veel zelfstandigen werkzaam. Daarbij is het opvallend dat het percentage in de landbouw en visserij ten opzichte van het landelijke cijfer nog relatief gering is. Algemeen is de trend voor het percentage zelfstandigen dalend. 
Tabel 2.1

Percentage flexibel werk, deeltijdwerk en zelfstandigen per bedrijfssector, Limburg, gemiddelde 1996-1997

\begin{tabular}{lccc} 
Bedrijfssector & flexibel werk & deeltijdwerk & zelfstandigen \\
\hline Landbouw en visserij & 23 & 30 & 54 \\
Voeding & 9 & - & - \\
Chemie & 10 & 8 & - \\
Metaal en elektrotechniek & - & 12 & - \\
Overige industrie & - & - & 12 \\
Energie & 9 & 33 & 16 \\
Bouw en onroerend goed & 10 & 19 & - \\
Handel & - & 19 & 24 \\
Transport en communicatie & 9 & 29 & 6 \\
Bank- en verzekeringswezen & 7 & 56 & - \\
Horeca, reparatie en zakelijke dienstverlening & - & 23 & 11 \\
Kwartaire diensten & & & \\
Overheid en onderwijs & 8 & 26 & \\
\hline Totaal & & & \\
\hline
\end{tabular}

Bron: CBS/ROA

\subsection{De werkgelegenheid naar beroepsgroep}

In deze paragraaf wordt gekeken naar de samenstelling en ontwikkeling van de werkgelegenheid verbijzonderd naar beroepsgroep. Met het oog op de overzichtelijkheid wordt de situatie slechts voor een beperkt aantal beroepen beschreven, i.c. de beroepen die de hoogste afwijkingen van het gemiddelde in positieve dan wel negatieve zin laten zien. Voor een integraal overzicht wordt verwezen naar de Statistische Bijlage, tabel 1.10. Tabel 2.2 geeft een overzicht van de grootste beroepsgroepen in de provincie Limburg, i.c. met meer dan 15.000 werkenden. De tabel laat een divers beeld zien. De boekhouders en secretaresses vormen de grootste beroepsgroep, op behoorlijke afstand gevolgd door de verkopers en de commercieel employés en chauffeurs. Bovendien is er bij de vier genoemde beroepsgroepen sprake van een stijgende trend in de werkgelegenheid. In tabel 2.3 worden de cijfers voor Limburg vergeleken met de landelijke situatie; het feit dat beroepen als metaalarbeiders, bankwerkers en lassers en bijvoorbeeld de procesoperators relatief hoog scoren in Limburg weerspiegelt het reeds eerder genoemde industriële karakter van de Limburgse economie. Bij een aantal van deze beroepen, zoals de assembleurs, is bovendien een sterk stijgende trend in de werkgelegenheid waarneembaar, zodat de Limburgse economie op dit punt in ieder geval niet in de richting van de nationale situatie convergeert. 
Tabel 2.2

Grootste aantal werkenden naar beroepsgroep, Limburg, gemiddelde 1996-1997

Beroepsgroep

Boekhouders en secretaresses

Verkopers

Commercieel employés

Chauffeurs

Monteurs

Receptionisten en administratieve employés aantal werkenden

27.000

21.000

18.000

18.000

17.000

15.000

Bron: CBS/ROA

Tabel 2.3

Beroepsgroepen die in Limburg ten opzichte van Nederland relatief groot zijn, gemiddelde 1996-1997

Beroepsgroep

aandeel Limburg

typering

t.o.v. Nederland

Assembleurs

3,26

1,54

1,38

1,38

1,38

1,37 erg hoog

erg hoog erg hoog erg hoog erg hoog erg hoog

Bron: CBS/ROA

Evenals in paragraaf 2.2 wordt ook hier een verdere uitsplitsing gemaakt naar de regio's Zuid- alsmede Noord- en Midden-Limburg. De tabellen 2.4 en 2.5 geven hiervan een overzicht. Zuid-Limburg laat ten opzichte van het provinciale beeld een ondervertegenwoordiging zien van de lagere agrarische beroepen alsmede van de lagere transportberoepen. Afwijkingen in positieve zin zijn vooral te constateren bij de wetenschappelijke beroepen. Dit is niet verrassend, gezien het feit dat de werkgelegenheid in de dienstensector en de overheid in het zuiden van de provincie geconcentreerd is. Figuur 2.3 heeft immers laten zien dat vooral in deze sectoren relatief veel hoogopgeleiden werkzaam zijn. De regio Noord- en Midden-Limburg laat natuurlijk daar het om afwijkingen ten opzichte van het provinciale gemiddelde gaat het tegenovergestelde beeld zien. De tabellen zijn een bevestiging van het minder verstedelijkte en meer geïndustrialiseerde beeld dat Noord-Limburg karakteriseert. 
Tabel 2.4

Relatief grootste aantal werkenden naar beroepssegment, Zuid-Limburg t.o.v. Limburg totaal, gemiddelde 1996-1997

Beroepssegment

Middelbare beroepen m.b.t gedrag en maatschappij

Hogere taalkundige, culturele beroepen

Hogere beroepen m.b.t. gedrag en maatschappij e.d.

Wetenschappelijke pedagogische beroepen

Wetenschappelijke (para-)medische beroepen e.d.

Managers (wetenschappelijk werk- en denkniveau)

Zuid-Limburg

typering

1,78

1,78

1,78

1,78

1,78

1,78 erg hoog erg hoog erg hoog erg hoog erg hoog erg hoog

Bron: CBS/ROA

Tabel 2.5

Relatief grootste aantal werkenden naar beroepssegment, Noord- en Midden-Limburg t.o.v. Limburg totaal, gemiddelde 1996-1997

Beroepssegment

Noord- en Midden- $\quad$ typering Limburg

Middelbare agrarische beroepen

2,29

1,48

1,14

1,11 erg hoog

erg hoog

hoog

hoog

Bron: CBS/ROA

\subsection{De werkgelegenheid naar opleidingstype}

In tabel 2.6 worden de belangrijkste opleidingsachtergronden van de werkenden in Limburg in beeld gebracht, i.c. opleidingen met meer dan 15.000 werkenden. Deze opleidingen liggen bijna allemaal op MBO-niveau of lager, waarbij het Basisonderwijs en het MAVO verreweg de meest voorkomende opleidingstypen zijn; bijna 70.000 werkenden (ruim 15\% van het totaal aantal werkenden) heeft één van deze twee opleidingen als achtergrond. Van de zes opleidingstypen die ten opzichte van de voorafgaande jaren de sterkste stijging in de werkgelegenheid laten zien, zijn er drie op MBO-, twee op HBO- en éen op WO-niveau; het betreft hier de opleidingen BOL/BBL motorvoertuigentechniek, BOL/BBL informatica, HBO commerciêle economie, HBO bedrijfskunde en WO (dier-) geneeskunde. De VBO-opleiding landbouw en natuurlijke omgeving laat de sterkste daling zien. Genoemde ontwikkelingen duiden erop dat er - zoals reeds eerder werd aangegeven - een duidelijk upgrading-proces gaande is. Voor de helft van de in tabel 2.6 genoemde opleidingstypen komt het beeld in Limburg overigens overeen met de landelijke situatie. Zoals ook al in het eerste RAIL-rapport werd geconstateerd, is het percentage werkenden met alleen Basisonderwijs in Limburg relatief hoog ten opzichte van het landelijke gemiddelde; het tegenovergestelde geldt voor de opleiding HAVO/VWO. Vooral op WO-niveau scoort Limburg ten opzichte van de landelijke cijfers erg laag. Dit beeld wordt geillustreerd in tabel 2.7 . 
Tabel 2.6

Grootste aantal werkenden naar opleidingstype, Limburg, gemiddelde 1996-1997

Opleidingstype

Basisonderwijs

MAVO

BOL/BBL administratie

HAVONWO

BOL/BBL handel

$\mathrm{BOL} / \mathrm{BBL}$ verzorging aantal werkenden

38.000

31.500

23.000

20.000

19.500

17.000

Bron: CBS/ROA

Tabel 2.7

Opleidingstypen die in Limburg relatief veel dan wel weinig voorkomen ten opzichte van Nederland, gemiddelde 1996-1997

Opleidingstype aandeel Limburg

typering

t.o.v. Nederland

BOL/BBL procestechniek
2,02

1,27

1,27

1,25

0,72

0,69

0,68

0,53 erg hoog erg hoog erg hoog erg hoog

HBO maatschappelijk werk en hulpverlening

WO rechten en bestuurskunde

WO wiskunde en natuurwetenschappen

WO sociale wetenschappen erg laag

erg laag

erg laag

erg laag

Bron: $C B S / R O A$

Een verbijzondering naar regio wordt wederom gemaakt in de tabellen 2.8 en 2.9 voor Zuid- respectievelijk Noord- en Midden-Limburg, nu naar opleidingssector. In ZuidLimburg blijken vooral de onderscheiden WO-sectoren sterk vertegenwoordigd te zijn, evenals $H B O$ sociaal-cultureel. Afwijkingen in positieve zin zijn in Noord- en MiddenLimburg te constateren bij de opleidingssectoren landbouw en natuurlijke omgeving op zowel VBO- als BOL/BBL-niveau en verder bij VBO techniek en VBO verzorging. 
Tabel 2.8

Relatief grootste aantal werkenden naar opleidingssector, Zuid-Limburg t.o.v. Limburg totaal, gemiddelde 1996-1997

Opleidingssector Zuid-Limburg typering

HBO sociaal-cultureel
WO techniek
WO medisch
WO sociaal-cultureel

1,78

1,78

1,78

1,78 erg hoog

erg hoog erg hoog erg hoog

Bron: CBS/ROA

Tabel 2.9

Relatief grootste aantal werkenden naar opleidingssector, Noord- en Midden-Limburg t.o.v. Limburg totaal, gemiddelde 1996-1997

Opleidingssector Noord- en Middentypering Limburg

VBO landbouw en natuurlijke omgeving BOL/BBL landbouw en nat. omgeving VBO verzorging VBO techniek

Bron: $C B S / R O A$

\subsection{Specifieke groepen op de Limburgse arbeidsmarkt}

In deze laatste paragraaf van dit hoofdstuk wordt aandacht besteed aan de werkgelegenheidsontwikkelingen voor jongeren (figuur 2.4), vrouwen (figuur 2.5) en ouderen (figuur 2.6). Gemiddeld over alle bedrijfssectoren vormen jongeren $25 \%$ van het totale werkende beroepsbevolking (landelijk 28\%); dit percentage daalt overigens door de verdergaande ontgroening van de bevolking. Relatief het grootste aantal jongeren is werkzaam in de handel (cf. vooral in de elementaire en lagere beroepen, zie de Statistische Bijlage). Het percentage jongeren is daarentegen erg klein bij de overheid en in het onderwijs, bovendien daalt het werkgelegenheidsaandeel van jongeren in deze sectoren. Jongeren zijn op de Limburgse arbeidsmarkt relatief zwak vertegenwoordigd; voor vijf van de dertien onderscheiden bedrijfssectoren scoort Limburg wat betreft het percentage jongeren laag ten opzichte van het landelijk gemiddelde. Dit kan redelijk eenvoudig worden verklaard door de sterkere ontgroening van het arbeidsaanbod in de provincie ten opzichte van het landelijke beeld. De Limburgse beroepsbevolking blijkt ook sneller te vergrijzen dan landelijk. Als gevolg van de ontgroening enerzijds en de vergrijzing anderzijds is met ingang van 1995 het aantal personen tussen de 15 en de 64 jaar gaan dalen. De groei van het aantal (hoog) bejaarden gaat in een hoog tempo door. Volgens voorspellingen van ETIL groeit bijvoorbeeld het aantal 75-plussers in Limburg de komende decennia met 3\% per jaar. Landelijk is deze groei wat lager. De vergrijzing komt ook tot uiting in de samenstelling van 
de werkzame bevolking in Limburg. De vergrijzing blijkt volgens figuur 2.5 het sterkst op te treden in de sectoren landbouw en visserij, overige industrie en overheid en onderwijs. Hierbij valt op dat de twee laatstgenoemde sectoren ook nog een sterk positieve trend laten zien, voor de landbouw en visserij geldt door toenemende bedrijfsbeēindiging onder ouderen het tegenovergestelde. Het percentage ouderen is in de sector overige industrie overigens ook landelijk gezien erg hoog.

Het aandeel vrouwen onder de Limburgse werkenden bedraagt tegenwoordig ongeveer $37 \%$; dit percentage is vrijwel stabiel. Vrouwen zijn voornamelijk werkzaam in de sectoren handel en kwartaire diensten; in sectoren met typische 'mannenberoepen' (zoals die in de industrie te vinden zijn) is hun aandeel daarentegen gering. Ten opzichte van het landelijke beeld zijn er weinig verschillen te constateren, met uitzondering van de sector landbouw en visserij waar het aandeel vrouwen erg hoog is in vergelijking met de landelijke situatie. Opvallend is tenslotte het feit dat in de sector kwartaire diensten, waar vrouwen een werkgelegenheidsaandeel van maar liefst $73 \%$ hebben, deeltijdwerk een veel voorkomend verschijnsel is, namelijk $56 \%$ van het totaal aantal werkenden. Dit is een indicatie dat vrouwen in deze sector gezin en werk combineren door in deeltijd te gaan werken.

Figuur 2.4

Percentage jongeren (jonger dan 30 jaar) per bedrijfssector in Limburg en in Nederland, gemiddelde 1996-1997

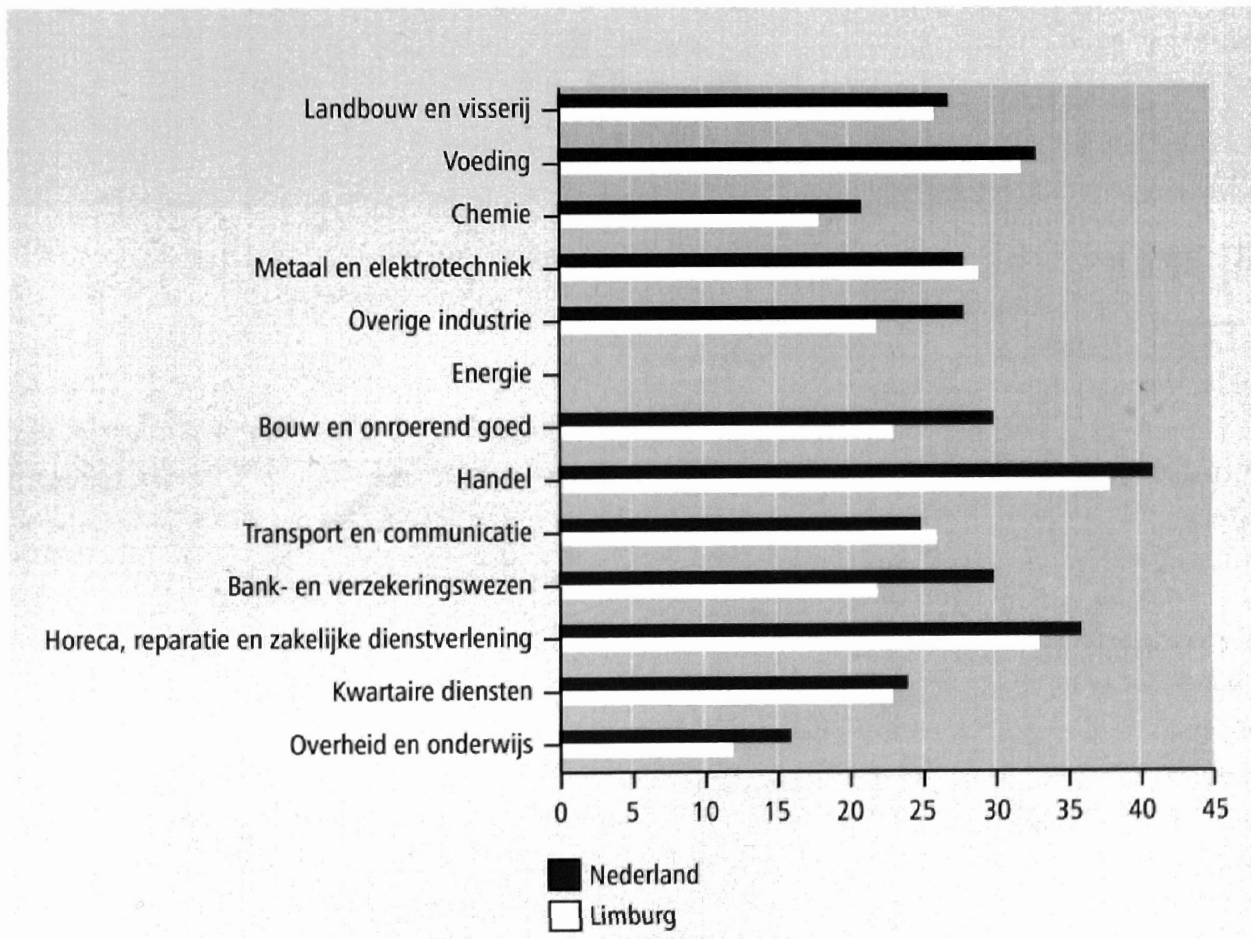


Figuur 2.5

Percentage ouderen (ouder dan 50 jaar) per bedrijfssector in Limburg en in Nederland, gemiddelde 1996-1997

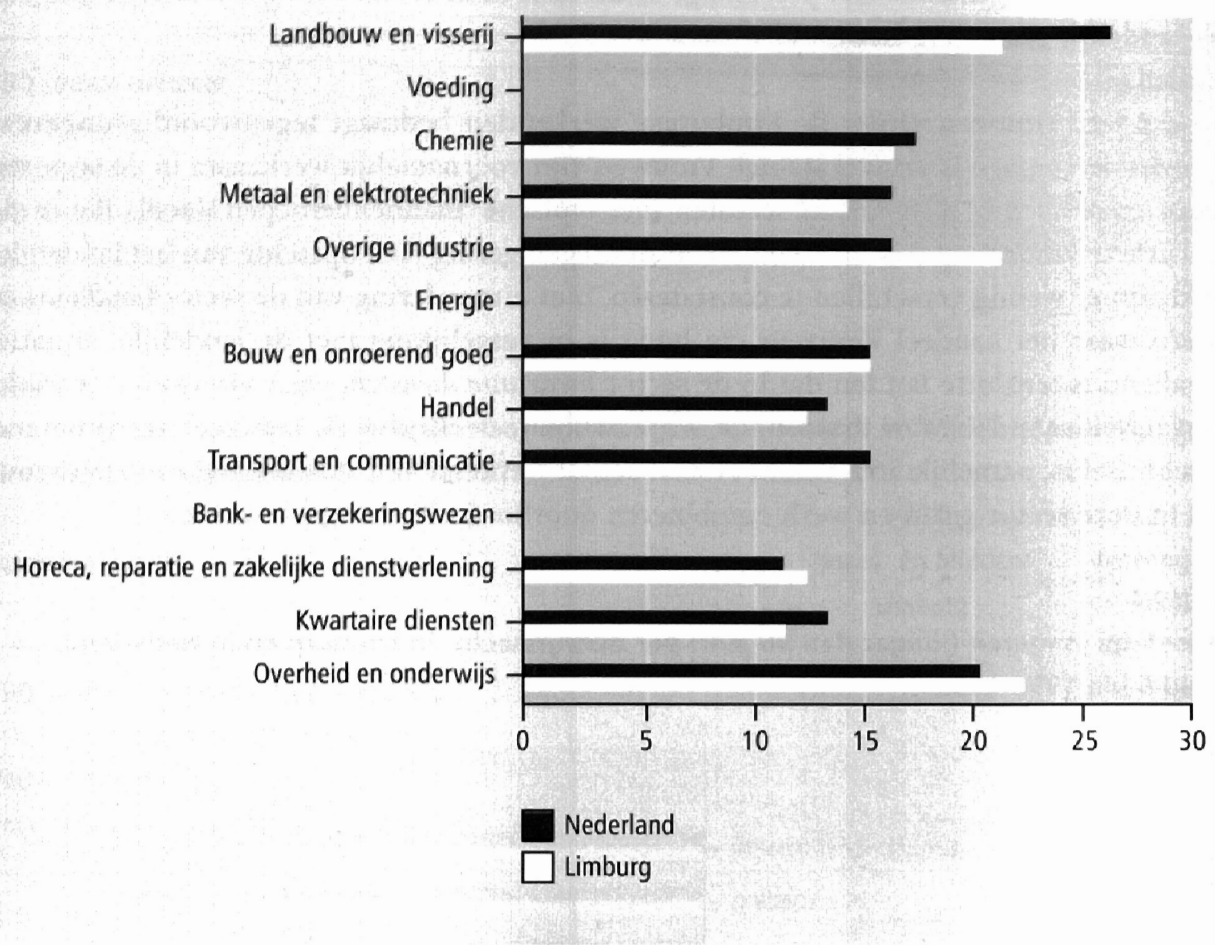




\section{Figuur 2.6}

Percentage vrouwen per bedrijfssector in Limburg en in Nederland, gemiddelde 1996-1997

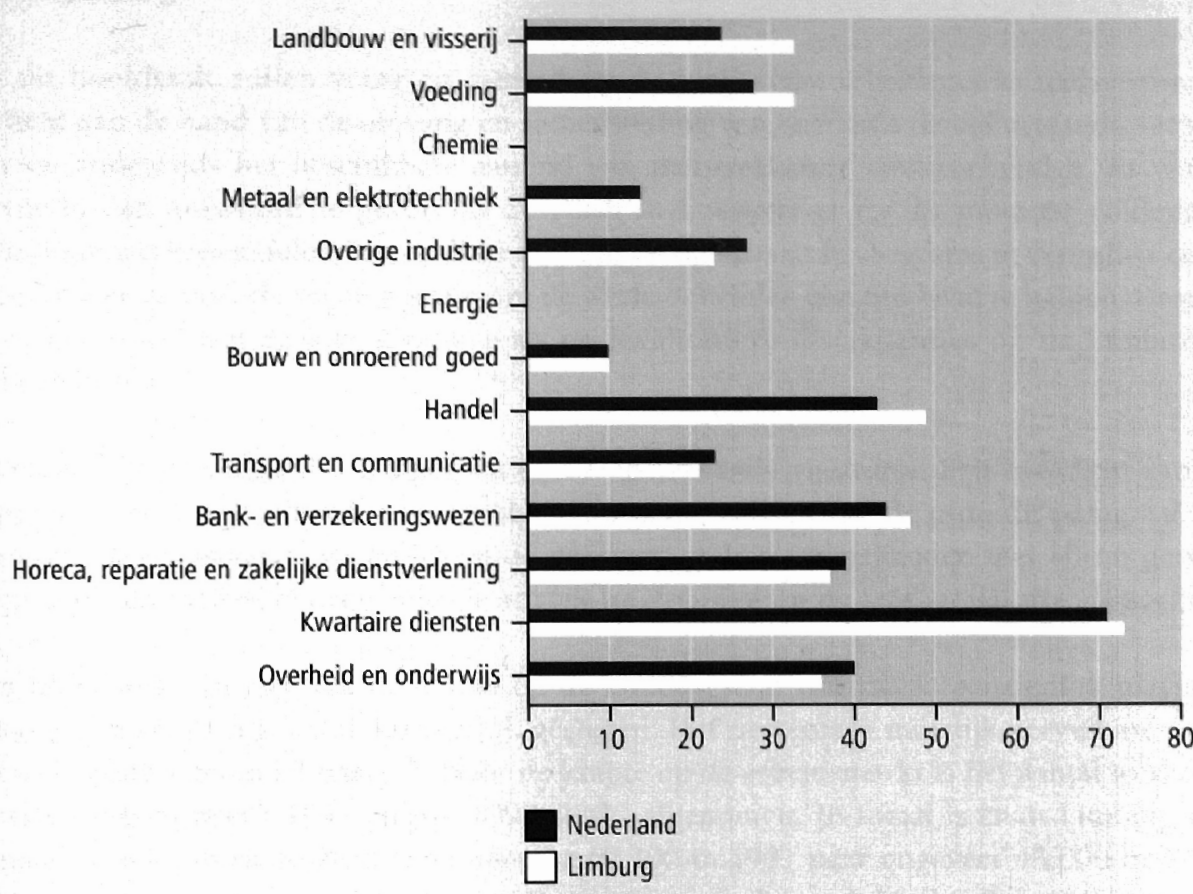




\section{Actuele discrepanties op de Limburgse arbeidsmarkt}

\subsection{Inleiding}

In dit hoofdstuk zullen vraag en aanbod op de Limburgse arbeidsmarkt nader worden belicht aan de hand van de omvang en samenstelling van enerzijds de openstaande vacatures en anderzijds het beschikbare aanbod van niet-werkende werkzoekenden. Er wordt getracht een antwoord te geven op de vraag in hoeverre er op dit moment voldoende geschikte werkzoekenden beschikbaar zijn om de openstaande vacatures te vervullen en in hoeverre er voldoende vacatures zijn om de werkzoekenden aan een baan te helpen. Daarbij gaat het zowel om de kwantitatieve als de kwalitatieve discrepanties op de Limburgse arbeidsmarkt.

Eerst wordt in paragraaf 3.2 ingegaan op de openstaande vacatures. Een overzicht van de aantallen werkzoekenden komt vervolgens in paragraaf 3.3 aan de orde. In paragraaf 3.4 worden de openstaande vacatures en de niet-werkende werkzoekenden met elkaar geconfronteerd om inzicht te krijgen in de actuele knelpunten op de Limburgse arbeidsmarkt.

Dit hoofdstuk laat zien dat de krapte op de Limburgse arbeidsmarkt aanzienlijk toegenomen is. De vacaturegraad is aanzienlijk gestegen. Het percentage moeilijk vervulbare vacatures is gestegen van 27 naar 32. Door de krapte op de arbeidsmarkt is het aantal werkzoekenden tussen maart 1997 en juli 1998 sterk afgenomen. In totaal is er in Limburg een afname van de werkloosheid van ongeveer 59.300 in 1997 naar ongeveer 43.000 in 1998. Dit is een daling van meer dan $25 \%$. Daarentegen is, hoewel de absolute aantallen zijn gedaald, zowel het aandeel van werkzoekenden met een grote afstand tot de arbeidsmarkt (bemiddelingsfase 4) als het aandeel langdurig werklozen toegenomen. Dit is een weerspiegeling van het feit dat, naarmate het aantal vacatures stijgt, de werkzoekenden met een geringe afstand tot de arbeidsmarkt het eerst emplooi vinden.

De verkrapping van de arbeidsmarkt komt tot uiting in het feit dat de verhouding tussen het aantal openstaande vacatures enerzijds en het aantal direct bemiddelbare werkzoekenden met een geringe afstand tot de arbeidsmarkt anderzijds tussen 1997 en 1998 cen radicale omwenteling heeft laten zien. In 1997 overtrof het aantal direct inzetbare werkzoekenden het aantal openstaande vacatures. Voor elke 100 werkzoekenden in fase 1 waren er slechts 39 openstaande vacatures beschikbaar. De situatie in 1998 is echter radicaal veranderd. Thans zijn er per 100 werkzoekenden maar liefst 222 openstaande vacatures beschikbaar. Als gevolg hiervan is in de meeste bedrijfssectoren sprake van een krappe arbeidsmarkt. Voor deze sectoren geldt dat de openstaande vacatures niet direct kunnen worden vervuld, wegens een tekort aan direct inzetbare werkzoekenden. Het is in ruim éen jaar dus aanzienlijk moeilijker geworden personeel te vinden om vacatures te vervullen. De problemen zijn het grootst in de commerciële dienstverlening: het bank-en verzekeringswezen en de horeca, reparatie en zakelijke dienstverlening. Dit sluit aan bij het beeld dat vorig jaar is geschetst. Op de arbeidsmarktsegmenten waar de landbouw, de bouw en de kwartaire diensten hun personeel werven is er sprake van een relatief geringe krapte. Deze sectoren hebben slechts te kampen met zeer specifieke knelpunten in de personeelsvoorziening 
Hoewel er moeilijk algemene conclusies getrokken kunnen worden, kan grofweg gesteld worden dat met name in de technische en de automatiseringsberoepen en opleidingen het tekort aan personeel kwantitatief van aard is. Er zijn eenvoudigweg te weinig werkzoekenden in het betreffende segment beschikbaar. In de administratieve en verzorgende beroepen en opleidingen heeft het tekort aan personeel vooral een kwalitatief karakter. Er is weliswaar voldoende aanbod maar dit aanbod voldoet niet aan de gestelde eisen: de afstand tot de arbeidsmarkt is te groot.

\subsection{Vacatures in Limburg}

\section{Vacatures naar bedrijfssector}

Een overzicht van de openstaande vacatures biedt een momentopname van de knelpunten die er aan de vraagzijde van de arbeidsmarkt optreden. In deze para graaf worden twee indicatoren gepresenteerd. Ten eerste wordt een indicatie gegeven van de vacaturegraad - het aantal vacatures per 1.000 werkenden - en ten tweede van het percentage langdurig openstaande vacatures, dat wil zeggen: de vacatures die langer dan drie maanden openstaan.

De vacaturegraad is in Limburg aanzienlijk toegenomen. In februari 1997 bedroeg het aantal openstaande vacatures bijna 25 per 1.000 werkenden. In juli 1998 bedroeg de vacaturegraad ruim $35^{13}$. Deze toename van de vacaturegraad illustreert de verdergaande verkrapping van de Limburgse arbeidsmarkt. Figuur 3.1 geeft een vergelijking van de vacaturegraad per bedrijfssector in februari 1997 en juli 1998. Voor alle sectoren, met uitzondering van de sector overheid en onderwijs, geldt dat de vacaturegraad is gestegen ten opzichte van vorig jaar. De sectoren landbouw en visserij, energie en transport en communicatie geven de grootste procentuele stijging van de vacaturegraad te zien ${ }^{14}$. De algehele stijging over de sectoren toont aan dat er een grote vraag is naar nieuwe werknemers. De sector met de grootste wervingsproblemen lijkt, net als vorig jaar, horeca, reparatie en zakelijke dienstverlening te zijn. In deze sector is er sprake van meer dan een verdubbeling van de vacaturegraad.

13 Enige discrepantie kan het gevolg zijn van het verschil in tijdstip van meten. Een seizoenscomponent speelt mee: in juli is er meer aanbod van werknemers (nieuwe schoolverlaters) en ook het aantal vacatures en met name de verdeling van vacatures over de verschillende arbeidsmarktsegmenten kan aan seizoensinvloeden onderhevig zijn.

If Met name voor de sector landbouw en visserij kan het feit dat er een vergelijking gemaakt wordt tussen februari $1997 \mathrm{en} \mathrm{juli} 1998$ enige vertekening geven. 
Figuur 3.1

Vacaturegraad naar bedrijfssector in Limburg, februari 1997 en juli 1998

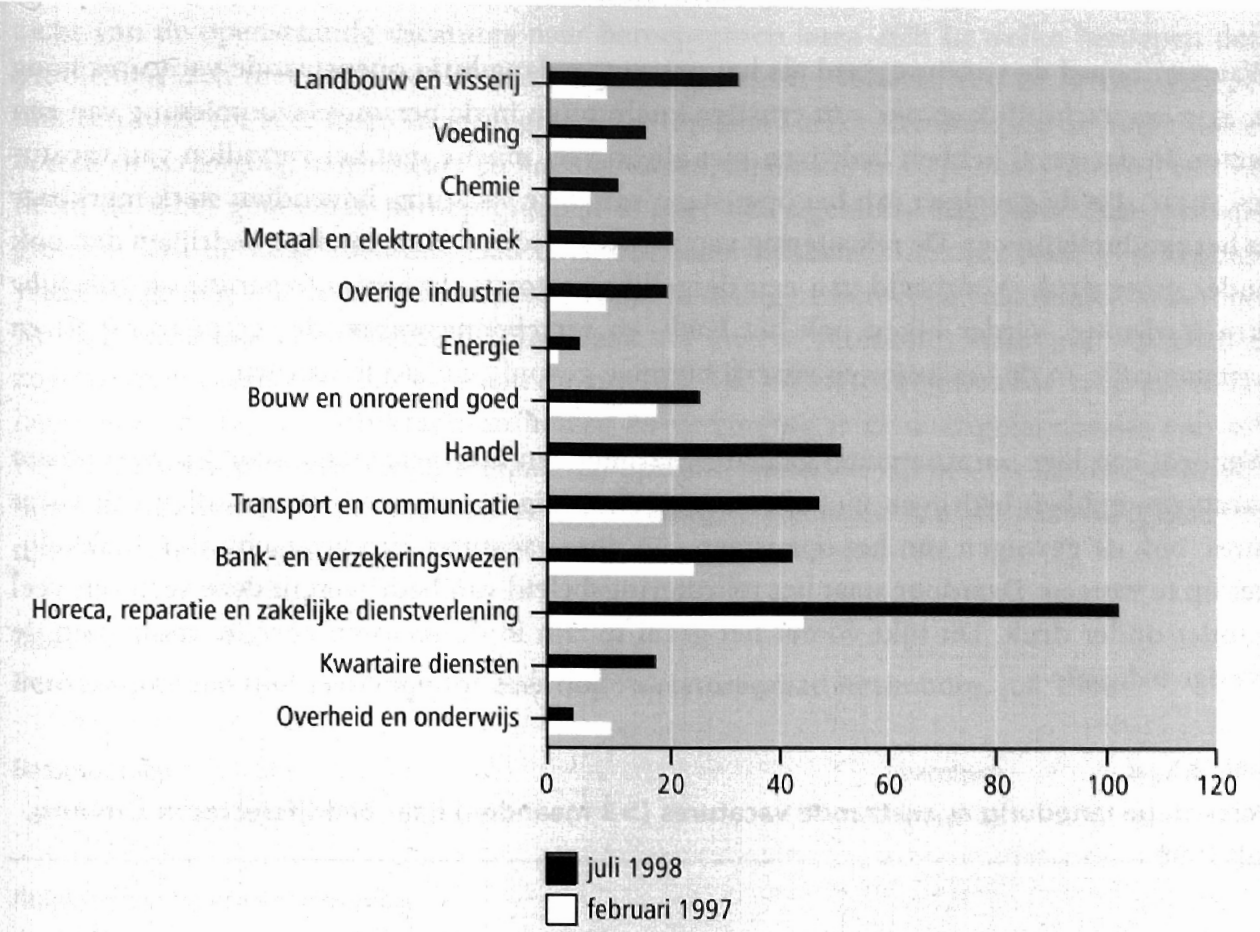

Bron: Arbeidsvoorziening/CBS/ROA

Ook in de sectoren handel en transport en communicatie is de vacaturegraad hoog. Net zoals in de sector horeca, reparatie en zakelijke dienstverlening is de vacaturegraad er sterk gestegen. De hoge vacaturegraad in de bovengenoemde sectoren geeft aan dat het relatief grote inspanningen vergt om te voorzien in de rekruteringsbehoefte, als gevolg van de groei in de werkgelegenheid of de vervangingsbehoefte. De vacaturegraad is daarentegen relatief laag in de overheidssector en de energiesector. Verder is de vacaluregraad aan de lage kant in de chemie en de voedingssector. Een lage vacaturegraad is een aanwijzing voor relatief kleine rekruteringsinspanningen gerelateerd aan de omvang van de bedrijfssector. Dit betekent echter niet dat er geen grote knelpunten in specifieke deelsectoren of segmenten van de arbeidsmarkt kunnen bestaan. Het feit dat er in genoemde sectoren relatief weinig nieuwkomers worden aangetrokken, impliceert niet noodzakelijkerwijs dat de rekruteringsproblemen in deze sectoren klein zijn. Daarvoor moet naast de vraag ook naar het aanbod van nieuwkomers worden gekeken.

Het percentage moeilijk vervulbare vacatures vormt een meer direct signaal voor het bestaan van rekruteringsproblemen in een sector. Tabel 3.1 geeft aan dat de percentages langdurig openstaande vacatures voor de sectoren dichter bij elkaar liggen dan de vacaturegraden. Ook het percentage langdurig openstaande vacatures is aanzienlijk toegenomen vergeleken met vorig jaar. In de chemie, de horeca, reparatie en zakelijke dienstverlening en 
in de sector overheid en onderwijs staat een groot percentage van de vacatures langer dan drie maanden open. In de sectoren energie, voeding, handel en de overige industrie is het percentage langdurig openstaande vacatures daarentegen relatief laag.

Wanneer zowel de vacaturegraad als het percentage langdurig openstaande vacatures hoog is, is er waarschijnlijk sprake van ernstige knelpunten in de personeelsvoorziening van een sector. In dat geval hebben bedrijven niet alleen veel moeite met het vervullen van vacatures, maar zijn de gevolgen van het openstaan van deze vacatures bovendien sterk merkbaar in het productieproces. De rekrutering van nieuw personeel staat bij deze bedrijven dan ook onder grote druk. Voorbeeld van een dergelijke sector is de horeca, reparatie en zakelijke dienstverlening. Verder lijken ook het bank- en verzekeringswezen, de sector transport en communicatie en de landbouw en visserij hiermee geconfronteerd te worden.

Wanneer een lage vacaturegraad gepaard gaat met een laag percentage moeilijk vervulbare vacatures, hebben bedrijven niet alleen relatief weinig moeite met het vervullen van vacatures, ook de gevolgen van het openstaan van deze vacatures zijn waarschijnlijk makkelijker op te vangen. Daardoor staat het rekruteringsbeleid van bedrijven in deze sectoren veel minder onder druk. Dit lijkt vooral het geval te zijn in de sectoren energie, voeding en de overige industrie.

Tabel 3.1

Percentage langdurig openstaande vacatures ( $>3$ maanden) naar bedrijfssector in Limburg, juli 1998

Bedrijfssector

Landbouw en visserij

Voeding

Chemie

Metaal en elektrotechniek

Overige industrie

Energie

Bouw en onroerend goed

Handel

Transport en communicatie

Bank- en verzekeringswezen

Horeca, reparatie en zak. dienstverl.

Kwartaire diensten

Overheid en onderwijs

Totaal

Bron: Arbeidsvoorziening/CBS/ROA
$\% \quad$ typering

\begin{tabular}{ll}
\hline 34 & hoog \\
21 & gemiddeld \\
38 & hoog \\
37 & hoog \\
24 & gemiddeld \\
18 & gemiddeld \\
31 & hoog \\
22 & gemiddeld \\
26 & hoog \\
37 & hoog \\
38 & hoog \\
34 & hoog \\
38 & hoog \\
\hline 32 & \\
\hline
\end{tabular}




\section{Vacatures naar beroepsgroep}

In aanvulling op het globale overzicht van de vacatures naar bedrijfssector, kan een overzicht van de openstaande vacatures naar beroepsgroep laten zien in welke beroepen deze problemen zich met name voordoen. Tabel 3.2 geeft een overzicht van de beroepsgroepen met een hoge tot zeer hoge vacaturegraad. De top drie heeft betrekking op de hulpkrachten horeca en verzorging, assembleurs en kantoorhulpen, inpakkers en colporteurs. Het niveau van de in de tabel genoemde beroepsgroepen is over het algemeen laag. Voor deze beroepsgroepen kan de hoge vacaturegraad twee oorzaken hebben. Enerzijds is de vervangingsvraag als gevolg van de arbeidsmarktuitstroom in de lagere beroepen vaak hoger, anderzijds worden vacatures voor hogere functies vaak via interne promoties opgevuld waardoor er zogenaamde vacatureketens ontstaan die uiteindelijk leiden tot een externe vacature in een lager beroep. Bij de hulpkrachten horeca en verzorging is er overigens sprake van een verdriedubbeling van de vacaturegraad ten opzichte van 1997. Ook voor de meeste andere beroepsgroepen is er sprake van een aanzienlijke toename van de vacaturegraad ten opzichte van het voorgaande jaar.

Tabel 3.2

Beroepsgroepen met een hoge tot zeer hoge vacaturegraad in Limburg, juli 1998

Beroepsgroep vacature- $\quad$ typering graad \%o

Hulpkrachten horeca en verzorging

Assembleurs

Kantoorhulpen, inpakkers en colporteurs

Interieurverzorgers

Chauffeurs

Verkopers

Productiemedewerkers

Receptionisten en administratieve employés

\begin{aligned} & \hline 121 zeer hoog \\ & 117 hoog \\ & 104 hoog \\ & 87 hoog \\ & 81 hoog \\ & 74 hoog \\ & 69 hoog \\ & 64 hoog \\ & \hline\end{aligned}

Bron: Arbeidsvoorziening/CBS/ROA

Tabel 3.3 geeft een overzicht van de beroepsgroepen die gekenmerkt worden door een zeer hoog percentage moeilijk vervulbare vacatures. Uit de tabel blijkt dat er hier meer sprake is van middelbare en hoge beroepsgroepen dan bij de beroepsgroepen met de hoogste vacaturegraden. Opvallend is ook dat de weg-en water bouwkundigen, de weg-en waterbouwkundige arbeiders én de weg-en waterbouwkundige vakkrachten in tabel 3.3 terug te vinden zijn. Dit duidt op specifieke rekruteringsproblemen in de grond-, weg- en waterbouw ${ }^{17}$. Het langdurig openstaan van de vacatures voor de technisch systeemanalisten, programmeurs en technisch-bedrijfskundig medewerkers duidt op een groot tekort aan informatici op de Limburgse arbeidsmarkt. De dynamiek van de ICT-sector speelt hierbij een belangrijke rol; met name

15 Hier zou het seizoenseffect een belangrijke rol kunnen spelen. Grond-, weg-, en waterbouwbedrijven blijken met name in de zomer rekruteringsproblemen te ondervinden. Voor de achtergronden van de knelpunten en de moeilijk vervulbare vacatures in de bouw, zie hoofdstuk 5 van dit rapport. 
ervaren personeel is daardoor schaars. Als gevolg daarvan is de concurrentie tussen bedrijven bij het vinden van nieuw personeel erg groot. De problemen bij het vinden van beveiligingspersoneel worden met name veroorzaakt door het feit dat de beschikbare ervaren krachten als te duur beschouwd worden door de sector. In de zorgsector wordt het tekort aan vooral verplegenden niet alleen veroorzaakt door het geringe aanbod, maar ook door het feit dat er relatief weinig opleidingsplaatsen beschikbaar zijn.

Het is overigens opmerkelijk dat geen enkele beroepsgroep zowel in tabel 3.2 als tabel 3.3 terug te vinden is. De technisch systeemanalisten en de weg-en waterbouwkundigen komen het dichtst in de buurt. Ze behoren tot de groepen met het hoogste percentage langdurig openstaande vacatures, maar vallen bij tabel 3.2 buiten de boot. Een betrouwbare cijfermatige indicatie van de vacaturegraad is moeilijk te geven; voor deze beroepsgroepen kan de vacaturegraad echter wel als 'hoog' worden getypeerd.

Wanneer we de tabel vergelijken met die van vorig jaar, valt op dat - met uitzondering van aspirant politieagenten, soldaten en beveiligingshulpkrachten en metaalarbeiders - de lijst van beroepsgroepen sterk is gewijzigd. De verpleeghulpen, verkopers en monteurs die vorig jaar met zeer grote rekruteringsproblemen te kampen hadden, komen dit jaar niet in de top tien voor. Dit wil niet zeggen dat werkgevers geen moeite meer hebben bij het vinden van nieuwe werknemers in deze beroepsgroepen, maar het toont wel aan dat de problemen op andere segmenten van de arbeidsmarkt sneller zijn toegenomen. De waargenomen verschuiving van rekruteringsproblemen van de ene groep beroepen naar de andere, is een indicatie van de dynamiek van de vacaturemarkt.

\section{Tabel 3.3}

Beroepsgroepen met een hoog tot zeer hoog percentage moeilijk vervulbare vacatures in Limburg, juli 1998

\begin{tabular}{lcc} 
Beroepsgroep & $\%$ & typering \\
\hline Tolken, vertalers en schrijvers & 100 & zeer hoog \\
Technisch systeemanalisten & 80 & zeer hoog \\
Programmeurs & 72 & zeer hoog \\
Asp. politieagenten, soldaten en beveiligingshulpkrachten & 65 & zeer hoog \\
Weg- en waterbouwkundige vakkrachten & 58 & zeer hoog \\
Weg- en waterbouwkundigen & 56 & zeer hoog \\
Technisch-bedrijfskundig medewerkers & 55 & hoog \\
Weg- en waterbouwkundige arbeiders & 53 & hoog \\
Metaalarbeiders & 52 & hoog \\
Verplegenden en doktersassistenten & 51 & hoog \\
\hline
\end{tabular}

Bron: Arbeidsvoorziening/ROA 


\section{Vacatures naar opleidingstype}

Vacatures hebben doorgaans in meer of mindere mate betrekking op een vraag naar specifieke kwalificaties. Een overzicht van de vacatures naar opleidingstype geeft inzicht in de problemen die ondervonden worden bij het vinden van personeel met een bepaalde opleidingsachtergrond. Tabel 3.4 geeft een overzicht van de opleidingstypen die gekenmerkt worden door een gemiddelde tot zeer hoge vacaturegraad. De tabel laat zien dat de opleidingen met een (zeer) hoge vacaturegraad niet geconcentreerd zijn in een bepaalde opleidingsrichting of op een bepaald opleidingsniveau. De opleidingen die gekenmerkt worden door een groot aantal vacatures in verhouding tot het aantal werkenden, zijn op alle niveaus en in verschillende vakrichtingen te vinden.

Het merendeel van de opleidingen in de tabel had ook vorig jaar al een hoge tot zeer hoge vacaturegraad. Wel valt op dat ook voor deze opleidingen de vacaturegraden verder zijn gestegen ten opzichte van 1997. Vorig jaar voerde VBO bouwtechniek de lijst ook al aan, maar toen met een vacaturegraad van $135 \%$ o. Nu is dit toegenomen tot boven de $200 \%$. Dit betekent dat voor dit opleidingstype er meer dan 200 openstaande vacatures zijn per 1.000 werkenden.

Tabel 3.4

Opleidingstypen met een gemiddelde tot zeer hoge vacaturegraad in Limburg, juli 1998

Opleidingstype

VBO bouwtechniek

HBO elektrotechniek

BOL sociaal-cultureel

HBO accountancy en bedrijfseconomie

BOL/BBL mech. techniek en werktuigbouwk.

BOL/BBL handel

BOL/BBL horeca

VBO landbouw en natuurlijke omgeving

$\mathrm{VBO}$ verzorging

BOL/BBL uiterlijke verzorging vacature- typering

graad $\% 0$

\begin{aligned} & \hline 217 zeer hoog \\ & 175 zeer hoog \\ & 166 zeer hoog \\ & 150 zeer hoog \\ & 145 zeer hoog \\ & 119 hoog \\ & 53 gemiddeld \\ & 48 gemiddeld \\ & 48 gemiddeld \\ & 44 gemiddeld \\ & \hline\end{aligned}

Bron: Arbeidsvoorziening/CBS/ROA

In tabel 3.5 wordt een overzicht gegeven van de opleidingstypen die een hoog tot zeer hoog percentage moeilijk vervulbare vacatures kennen. Deze tabel laat zien dat de opleidingstypen met een hoog percentage vacatures die langer dan drie maanden open staan, te vinden zijn in technische, agrarische en medische richtingen. BOLBBL laboratorium en $H B O$ landbouw en veeteelt spannen de kroon, elk met $100 \%$ moeilijk vervulbare vacatures in Limburg. 
Tabel 3.5

Opleidingstypen met een hoog tot zeer hoog percentage moeilijk vervulbare vacatures in Limburg, juli 1998

Opleidingstype

BOL/BBL laboratorium

HBO landbouw en veeteelt

BOL/BBL milieu en groene ruimte

BOL/BBL operationele techniek

BOL/BBL toerisme

$B O L B B L$ verpleegkunde

VBO landbouw en natuurlijke omgeving

HBO elektrotechniek

BOL/BBL beweging en therapie

VBO horeca

\begin{aligned} &$\%$ typering \\ & \hline 100 zeer hoog \\ & 100 zeer hoog \\ & 67 zeer hoog \\ & 60 zeer hoog \\ & 57 zeer hoog \\ & 56 zeer hoog \\ & 54 hoog \\ & 52 hoog \\ & 51 hoog \\ & 50 hoog \\ & \hline\end{aligned}

Bron: Arbeidsvoorziening/ROA

Als een opleidingstype in zowel tabel 3.4 als tabel 3.5 voorkomt, dan geeft dit aan dat er sprake is van ernstige knelpunten in de personeelsvoorziening voor mensen met de desbetreffende opleidingsachtergrond. Vooral bij VBO landbouw en natuurlijke omgeving, $B O L B B L$ horeca en bij $H B O$ elektrotechniek is er sprake van grote rekruteringsproblemen. Bij deze opleidingen is de vacaturegraad gemiddeld tot zeer hoog en is er bovendien sprake van een hoog percentage moeilijk vervulbare vacatures. Ook de in de tabellen 3.4 en 3.5 geschetste vacatureproblematiek naar opleidingstype weerspiegelt het beeld van de rekruteringsproblemen per bedrijfssector.

\subsection{Werkzoekenden in Limburg}

In paragraaf 3.2 werd de vraagzijde van de arbeidsmarkt belicht door middel van een overzicht van de openstaande vacatures. In deze paragraaf staat de aanbodzijde centraal met een overzicht van de bij Arbeidsvoorziening ingescheven niet-werkende werkzoekenden. Achtereenvolgens wordt aandacht geschonken aan de werkzoekenden naar beroepsgroep en naar opleidingstype.

Figuur 3.2 geeft een beeld van het aantal niet-werkende werkzoekenden in Limburg met een verbijzondering naar de regio's Noord- en Midden-Limburg en Zuid-Limburg. Te zien is dat het aantal werkzoekenden tussen maart 1997 en juli 1998 sterk is afgenomen. In totaal is er in Limburg een afname van de werkloosheid van ongeveer 59.300 in 1997 naar ongeveer 43.000 in 1998. Dit is een daling van meer dan $25 \%$. De verdeling van werkzoekenden over de twee regio's is nagenoeg hetzelfde gebleven. Zuid-Limburg herbergt het leeuwendeel met ruim $60 \%$ en voor Noord- en Midden-Limburg resteert bijna $40 \%$. 
Aantal niet-werkende werkzoekenden in Noord- en Midden-Limburg, Zuid-Limburg en Limburg, maart 1997 en juli 1998

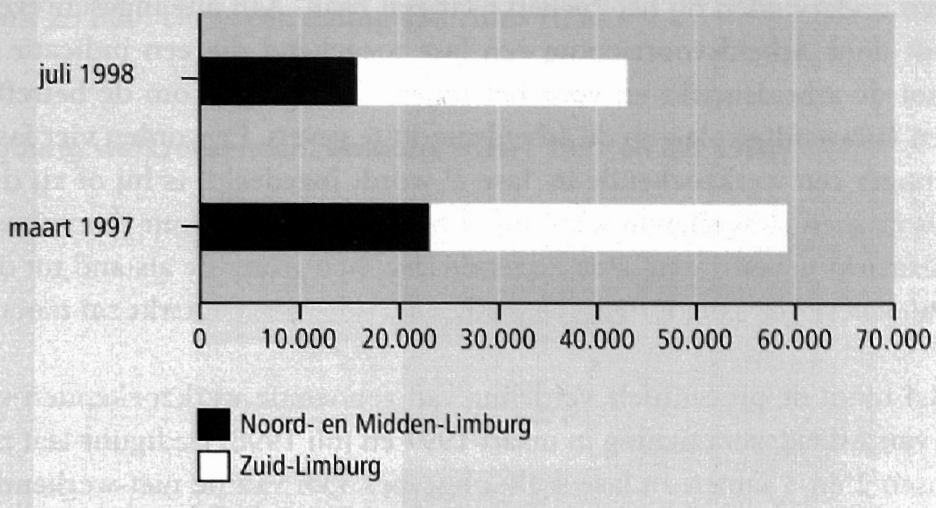

Bron: Arbeidsvoorziening/ROA

Figuur 3.3 schetst een beeld van de niet-werkende werkzoekenden als percentage van het aantal werkenden (werkloosheidspercentage) voor de twee regio's en Limburg als geheel, voor 1997 en 1998. In de figuur is te zien dat voor beide jaren het werkloosheidspercentage in Zuid-Limburg groter is dan dat in Noord- en Midden-Limburg. Daarnaast is een afname van het werkloosheidspercentage waar te nemen. Voor Zuid-Limburg was deze afname het grootst (van ruim 15\% in 1997 naar minder dan 11\% in 1998). Deze daling in het werkloosheidspercentage is niet alleen relatief. Zoals figuur 3.2 reeds liet zien, is ook absoluut gezien het aantal werklozen afgenomen.

Figuur 3.3

Niet-werkende werkzoekenden als percentage van het aantal werkenden, Noord- en Midden-Limburg, Zuid-Limburg en Limburg, maart 1997 en juli 1998

Noord- en Midden-Limburg Zuid-Limburg Limburg

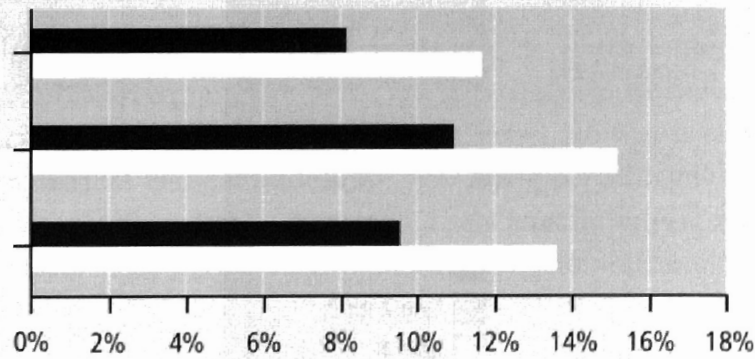

juli 1998

maart 1997 


\section{Langdurige werkloosheid en fasen van bemiddelbaarheid}

Langdurig werklozen hebben vaak een grote afstand tot de arbeidsmarkt. Het zogenaamde faseringsmodel van Arbeidsvoorziening biedt een nadere kijk op de problemen die werkzoekenden ondervinden bij het zoeken naar een baan. Aan alle ingeschreven werkzoekenden wordt door Arbeidswoorziening een fase toegekend die een indicatie vormt voor de afstand tot de arbeidsmarkt en voor het traject dat nodig is om de betreffende werkzoekende een volwaardige plek op de arbeidsmarkt te geven. Er worden vier fasen onderscheiden. Wanneer een werkzoekende in 'fase l' wordt ingedeeld, is hij of zij direct bemiddelbaar en is er geen aanvullende scholing of begeleiding nodig om een volwaardige plek op de arbeidsmarkt te veroveren. Hoe hoger de fase, hoe groter de afstand tot de arbeidsmarkt en hoe intensiever en langduriger het traject naar de arbeidsmarkt zal moeten zijn ${ }^{16}$.

Figuur 3.4 toont de procentuele verdeling van genoemde werkzoekenden volgens de faseindeling van Arbeidsvoorziening in maart 1997 en juli 1998. De figuur laat zien dat in 1997 fase 1, fasen 2 en 3 samen en fase 4 elk ongeveer 33\% van de niet-werkende werkzoekenden bevatten. Echter: 1998 geeft een ander beeld te zien. Het aandeel direct-bemiddelbare werkzoekenden - degenen ingedeeld in fase 1 - is gedaald tot minder dan $20 \%$ van het totaal aantal werkzoekenden. Dit is het logische gevolg van de verkrapping van de arbeidsmarkt en de daaruit voortvloeiende daling in het aantal werkzoekenden, zoals reeds naar voren kwam uit figuur 3.2. De verkrapping heeft in eerste instantie tot een afroming van het reservoir aan direct inzetbare werkzoekenden geleid. Daardoor is het percentage werkzoekenden dat in fase 4 is ingedeeld toegenomen. Absoluut gezien is het aantal werkzoekenden in fase 4 echter wel gedaald.

Figuur 3.4

Procentuele verdeling werkzoekenden fase van bemiddelbaarheid, Limburg, maart 1997 en juli 1998

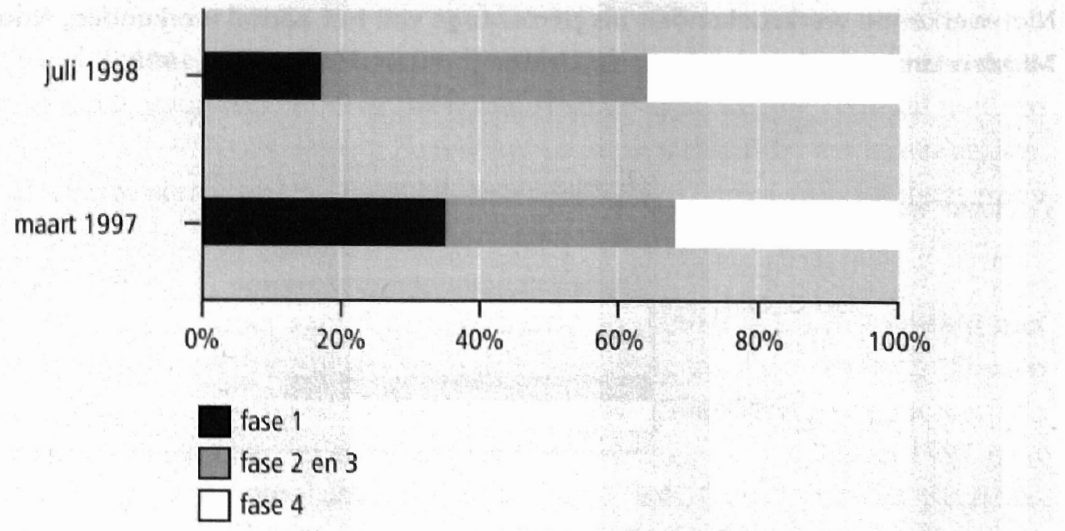

Bron: Arbeidsvoorziening/ROA

16 Meer informatic met betrekking tot de interpretatie van de verschillende fasen in het faseringsmodel is te vinden in de verklarende woordenlijst achterin dit rapport en in Arbeidsvoorziening Limburg, Bemiddelingsbestand Arbeidsvoorziening Limburg: een indeling in fasen, 1996. 
Figuur 3.5 laat zien dat, net als het percentage werkzoekenden in fase 4, het aandeel van de langdurig werkzoekenden in de totale werkloosheid gestegen is, en wel van $59 \%$ naar $62 \%$. De langdurig werklozen hebben dus minder geprofiteerd van de verkrapping van de arbeidsmarkt. Absoluut gezien is het aantal langdurig werklozen wel gedaald van bijna 32.000 naar ruim 28.000. Dit is een daling van ruim $10 \%$.

Figuur 3.5

Percentage langdurig werkzoekenden, Limburg, maart 1997 en juli 1998

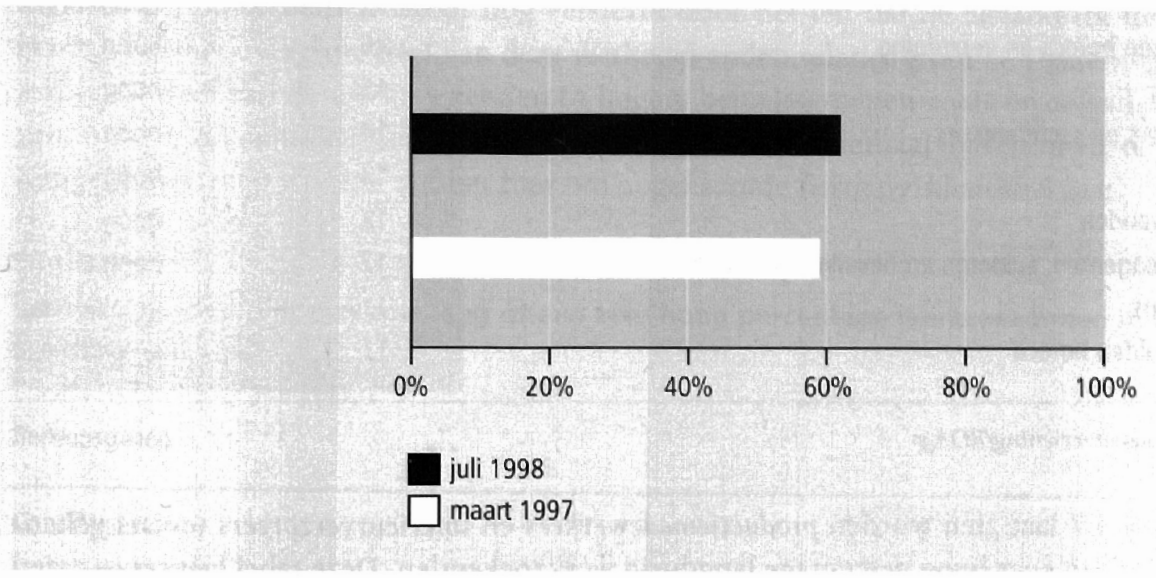

Bron: Arbeidsvoorziening/ROA

In de figuren 3.4 en 3.5 zagen we dat zowel het aandeel van werkzoekenden ingedeeld in fase 4 als het aandeel langdurig werklozen is toegenomen. Dit is een weerspiegeling van het feit dat, naarmate het aantal vacatures stijgt, de werkzoekenden met een geringe afstand tot de arbeidsmarkt het eerst emplooi vinden. Hoewel de plaatsingskans van langdurig werklozen stijgt dankzij extra aandacht van Arbeidsbureaus, vermindert hun aandeel in de werkloosheid (ondanks een daling in de absolute omvang) niet ${ }^{17}$.

\section{Werkzoekenden naar beroepsgroep}

Wanneer een werkzoekende zich inschrijft bij het arbeidsbureau, wordt onder andere het wensberoep geregistreerd. Dit maakt het mogelijk inzicht te krijgen in de beroepsgroepen waarin de werkzoekenden emplooi zouden willen vinden. In tabel 3.6 word t een overzich gegeven van de beroepsgroepen met een gemiddeld tot zeer hoog percentage werkzoekenden. Uit de tabel blijkt dat vooral elementaire beroepen zoals kantoorhulpen, inpakkers en colporteurs, productie-medewerkers en interieurverzorgers worden gekenmerkı door cen zeer hoog percentage werkzoekenden. 
Tabel 3.6

Beroepsgroepen met een gemiddeld tot zeer hoog aantal niet-werkende werkzoekenden als percentage van de werkgelegenheid in Limburg, juli 1998

\begin{tabular}{lll} 
Beroepsgroep & $\%$ & typering \\
\hline Productiemedewerkers & 83 & zeer hoog \\
Kantoorhulpen, inpakkers en colporteurs & 54 & zeer hoog \\
Interieurverzorgers & 31 & zeer hoog \\
Hulpkrachten horeca en verzorging & 26 & hoog \\
Chauffeurs & 15 & hoog \\
Boekhouders en secretaresses & 14 & hoog \\
Verkopers & 13 & hoog \\
Leidinggevenden & 12 & hoog \\
Asp. politieagenten, soldaten en beveiligingshulpkr. & 12 & hoog \\
Assembleurs & 11 & gemiddeld \\
Bedrijfshoofden horeca & 11 & gemiddeld
\end{tabular}

Bron: Arbeidsvoorziening/ROA

Zoals tabel 3.7 laat zien worden productiemedewerkers en interieurverzorgers tevens gekenmerkt door een zeer hoog percentage langdurig werkzoekenden. Deze tabel laat tevens zien dat ook op middelbaar en hoger niveau een aantal beroepsgroepen gekenmerkt wordt door een zeer hoog percentage werkzoekenden die meer dan een jaar ingeschreven zijn bij het arbeidsbureau ${ }^{18}$.

\section{Tabel 3.7}

Beroepsgroepen met een zeer hoog percentage langdurig werkzoekenden in Limburg, juli 1998

\begin{tabular}{lll} 
Beroepsgroep & $\%$ & typering \\
\hline Laders en lossers & 83 & zeer hoog \\
Taalkundigen & 79 & zeer hoog \\
Winkeliers & 79 & zeer hoog \\
Kunstenaars & 76 & zeer hoog \\
Grafische vakkrachten & 73 & zeer hoog \\
Interieurverzorgers & 73 & zeer hoog \\
Conciërges & 72 & zeer hoog \\
Apothekersassistenten en medisch laboranten & 72 & zeer hoog \\
Productiemedewerkers & 70 & zeer hoog \\
Schoen- en kleermakers & 70 & zeer hoog \\
\hline
\end{tabular}

Bron: Arbeidsvoomicning/ROA

18 Opgemerkt dient te worden dat dit niet noodzakelijkerwijs impliceert dat deze werkzoekenden meer dan een jatar zonder werk zitten, ondat het vinden van werk niet altijd betekent dat men zich laat uitschrijven als werkzoekende bij het arbeidsbureau. 
Het percentage werkzoekenden in fase 1 vormt een belangrijke indicator voor de 'kwaliteit' van de werkzoekenden op een bepaald arbeidsmarktsegment door aan te geven welk deel van de werkzoekenden direct inzetbaar is op de arbeidsmarkt. In tabel 3.8 wordt een overzicht gegeven van de beroepsgroepen met het hoogste en met het laagste percentage werkzoekenden in fase 1. Deze tabel laat zien dat de beroepsgroepen met een zeer laag percentage direct bemiddelbare werkzoekenden in fase l vooral te vinden zijn bij de elementaire beroepen aan de onderkant van de arbeidsmarkt. Bij deze beroepsgroepen is niet alleen sprake van een hoog werkloosheidspercentage en een hoog percentage langdurig werkzoekenden. De problematiek wordt nog versterkt door het feit dat de afstand tot de arbeidsmarkt voor het overgrote deel van deze werkzoekenden relatief groot is. Daarentegen blijkt een groot deel van de werkzoekenden in hogere beroepsgroepen zoals organisatiedeskundigen, artsen, accountants en juristen als zeer goed bemiddelbaar beschouwd te worden. Aangenomen mag worden dat het hier om zogenaamde frictiewerkloosheid gaat.

\section{Tabel 3.8}

Beroepsgroepen met een zeer laag of een zeer hoog percentage werkzoekenden in fase 1 , Limburg, juli 1998

Beroepsgroep

$\% \quad$ typering

Conciërges

Laders en lossers

Productiemedewerkers

Interieurverzorgers

Schoen- en kleermakers

Bibliotheekassistenten

Organisatiedeskundigen

5 zeer laag

5 zeer laag

$8 \quad$ zeer laag

8 zeer laag

0 zeer laag

Accountants

Artsen

Laboranten

Verzekeringsagenten

Therapeuten en verpleegkundigen

11 zeer laag

47 zeer hoog

Docenten (onuitgesplitst)

Juristen

45 zeer hoog

44 zeer hoog

43 zeer hoog

38 zeer hoog

38 zeer hoog

38 zeer hoog

35 zeer hoog

Bron: Arbeidsvoorziening/ROA

\section{Werkzoekenden naar opleidingstype}

De opleidingsachtergrond vormt een belangrijke determinant van iemands arbeidsmarktpositie. Naast een overzicht van het percentage werkzoekenden per beroepsgroep is derhalve ook inzicht in de opleidingsachtergrond van de werkzoekenden van groot belang. In tabel 3.9 wordt een overzicht gegeven van de opleidingstypen die gekenmerkı worden door een gemiddeld tot zeer hoog percentage werkzoekenden ${ }^{19}$.

19 Opgemerkt dient te worden dat de opleidingsachtergrond niet alleen bepaald wordt door de gevolgde initiéle opleiding, maar ook door de gevolgde aanvullende scholing. 
Uit de tabel blijkt dat met name de lager opgeleiden geconfronteerd worden met relatief hoge werkloosheidspercentages. Vooral de opleidingen VBO bouwtechniek, VBO administratie en handel en VBO verzorging vallen daarbij in negatieve zin op. Dit beeld sluit aan bij de hoge werkloosheidspercentages in de elementaire en lagere beroepsgroepen. Zeer opvallend is het hoge percentage werkzoekenden met als opleidingsachtergrond BOL/BBL informatica. Dít zou veroorzaakt kunnen zijn door het grote aantal werkzoekenden dat zijn arbeidsmarktkansen tracht te vergroten door het volgen van opleidingen en cursussen op het gebied van automatisering. Opmerkelijk is ook dat de werkloosheidspercentages in deze tabel allemaal aanzienlijk lager liggen dan de in tabel 3.6 gepresenteerde werkloosheidspercentages van productiemedewerkers en kantoorhulpen, inpakkers en colporteurs. Dit wijst er op dat deze beroepsgroepen in feite een vergaarbak vormen voor werkzoekenden met uiteenlopende opleidingsachtergronden. Het is dan ook niet reëel te verwachten dat deze werkzoekenden juist in deze beroepsgroepen een baan zullen kunnen vinden.

Tabel 3.9

Opleidingstypen met een gemiddeld tot zeer hoog aantal niet-werkende werkzoekenden als percentage van de werkgelegenheid in Limburg, juli 1998

Opleidingstype

VBO bouwtechniek

VBO verzorging

BOL/BBL informatica

VBO administratie en handel

Basisonderwijs

MAVO

BOL/BBL mechanische techniek en werktuigbouwk.

BOL sociaal-cultureel

HAVONWO

VBO landbouw en natuurlijke omgeving

$\% \quad$ typering

\begin{tabular}{ll}
\hline 44 & zeer hoog \\
37 & zeer hoog \\
35 & zeer hoog \\
30 & zeer hoog \\
20 & hoog \\
20 & hoog \\
20 & hoog \\
12 & hoog \\
12 & gemiddeld \\
11 & gemiddeld \\
\hline
\end{tabular}

Bron: Arbeidsvoorziening/ROA

In tabel 3.10 wordt een overzicht gegeven van de opleidingen die gekenmerkt worden door een hoog percentage langdurig werkzoekenden. De tabel geeft een divers beeld te zien en omvat zowel lagere als hogere opleidingen en zowel technische als medische opleidingen.

Een overzicht van het percentage werkzoekenden dat in fase 1 is ingedeeld per opleidingstype in tabel 3.11 bevestigt het diverse beeld voor de werkloosheidsproblematiek naar opleiding. Terwijl direct bemiddelbare werkzoekenden duidelijk ondervertegenwoordigd zijn in de elementaire en lage beroepen (zie tabel 3.8), is deze scheiding veel minder scherp voor opleidingen ${ }^{20}$.

20 In paragraaf 3.4 zal dieper op de fasering van de werkzoekenden worden ingegaan. 
Tabel 3.10

Opleidingstypen met een hoog tot zeer hoog percentage langdurig werkzoekenden in Limburg, juli 1998

\begin{tabular}{lll} 
Opleidingstype & $\%$ & typering \\
\hline Basisonderwijs & 78 & zeer hoog \\
HBO uitvoerend en beelden kunstenaar & 74 & zeer hoog \\
VBO verzorging & 70 & zeer hoog \\
BOL/BBL elektrotechniek & 70 & zeer hoog \\
BOL/BBL installatietechniek & 68 & hoog \\
BOL/BBL levensmiddelentechniek/vleesverwerking & 68 & hoog \\
HBO leraar economie en maatschappij & 67 & hoog \\
VBO administratie en handel & 66 & hoog \\
BOL/BBL verzorging & 65 & hoog \\
BOL/BBL verpleegkunde & 64 & hoog \\
\hline
\end{tabular}

Bron: Arbeidsvoorziening/ROA

Tabel 3.11

Opleidingstypen met een laag tot zeer laag of een zeer hoog percentage werkzoekenden in fase 1, Limburg, juli 1998

Opleidingstype

Basisonderwijs

VBO verzorging

BOL/BBL levensmiddelentechniek/vleesverwerking

$\mathrm{BOL} / \mathrm{BBL}$ milieu en groene ruimte

$\mathrm{HBO}$ uitvoerend en beeldend kunstenaar

BOL/BBL toerisme

$\mathrm{HBO}$ tolk en vertaler

BOL/BBL laboratorium

HBO personeelswerk

$\mathrm{HBO}$ accountancy en bedrijfseconomie

VBO horeca
$\% \quad$ typering

5

zeer laag

zeer laag

zeer laag

laag

laag

13

zeer hoog

41 zeer hoog

41 zeer hoog

40 zeer hoog

38 zeer hoog

37 zeer hoog

Bron: Arbeidsvoorziening/ROA

\subsection{Kwantitatieve en kwalitatieve discrepanties in Limburg}

In de voorafgaande paragrafen zijn de vraag naar en het aanbod van arbeid in kaart gebracht. Deze analyses maken het mogelijk om in deze paragraaf door middel van een confrontatie van de openstaande vacatures en de niet-werkende werkzoekenden inzicht te verkrijgen in de actuele knelpunten op de Limburgse arbeidsmarkt. Alvorens in te gaan op 
de discrepanties naar respectievelijk bedrijfssector, beroepsgroep en opleidingstype zal eerst het raamwerk waarop deze paragraaf gebaseerd is uiteengezet worden.

\section{Discrepantiemaatstaven en typering arbeidsmarktkrapte}

Uitgangspunt is het eenvoudige principe dat een vergelijking van het aantal openstaande vacatures en het aantal niet-werkende werkzoekenden de vraag-aanbodverhouding in een arbeidsmarktsegment weergeeft. Wanneer het aantal openstaande vacatures het aantal werkzoekenden overtreft is er sprake van een tekort. Wanneer daarentegen het aantal werkzoekenden groter is dan het aantal openstaande vacatures is er sprake van een overschot in het betreffende arbeidssegment. Een nuancering is hier echter op zijn plaats. Niet elke werkzoekenden wordt als geschikt beschouwd om vacatures te vervullen. De afstand tot de arbeidsmarkt is niet voor iedere werkzoekende gelijk. Het is daarom zeer gebruikelijk om in discrepantie- analyses een onderscheid te maken tussen direct bemiddelbare werkzoekenden en werkzoekenden met een grotere afstand tot de arbeidsmarkt ${ }^{21}$.

Om de afstand van werkzoekenden tot de arbeidsmarkt te typeren wordt het faseringsmodel van Arbeidsvoorziening gehanteerd. Bij deze fase-indeling wordt, zoals gezegd, een onderscheid gemaakt in vier fasen. Werkzoekenden in fase 1 zijn onmiddellijk bemiddelbaar voor de arbeidsmarkt. Werkzoekenden in fase 2 en 3 hebben respectievelijk een kort of een langer scholings- of begeleidingsprogramma nodig om hun arbeidsmarktkansen te vergroten. Werkzoekenden in fase 4 worden daarentegen (voorlopig) niet in staat geacht een volwaardige plaats op de arbeidsmarkt te verwerven. Aangezien werkgevers primair geinteresseerd zijn in mensen die direct inzetbaar zijn, ligt het voor de hand de arbeidsmarktkrapte op een bepaald arbeidsmarktsegment te definiëren als de verhouding tussen het aantal openstaande vacatures en het aantal werkzoekenden in fase 1 op het betreffende arbeidsmarktsegment. Wanneer de arbeidsmarktkrapte groter is dan één, is er sprake van een tekort aan direct inzetbare werkzoekenden. Wanneer de arbeidsmarktkrapte kleiner is dan één is er sprake van een overschot.

Wanneer er sprake is van een tekort aan direct inzetbare werkzoekenden, zullen de vacatures ook opgevuld moeten worden door de werkzoekenden die een grotere afstand tot de arbeidsmarkt hebben. Vanwege het tekort aan direct inzetbare werkzoekenden kunnen deze minder goed bemiddelbare werkzoekenden door middel van een scholings- of begeleidingstraject hun kansen op een baan aanzienlijk vergroten. De knelpuntsindicator geeft aan in hoeverre er werkzoekenden in fase 2 en 3 beschikbaar zijn. Het is tevens een indicator voor de arbeidsmarktkansen van de werkzoekenden in fase 2 en 3. De knelpuntsindicator is gedefinieerd als de verhouding tussen enerzijds het aantal openstaande vacatures waarvoor geen werkzoekenden in fase 1 gevonden kunnen worden en anderzijds het aantal werkzoekenden in fase $2 \mathrm{en} 3$. Wanneer er sprake is van een overschot aan direct inzetbare werkzoekenden, is de knelpuntsindicator nul. Aangezien er meer dan genoeg direct inzetbare werkzoekenden zijn, zijn er geen knelpunten en zijn de mogelijkheden voor werkzoekenden in fase 2 en 3 om via een bijscholings- of bege leidingstraject hun arbeidsmarktkansen op korte termijn te vergroten nul. Wanneer er sprake is van een tekort aan direct

21 J. Hartog. Tussen vraag en aanbod, Stenfert Kroese, Leiden, 1980. 
inzetbare werkzoekenden bestaat er een knelpunt en zijn er reële arbeidsmarktkansen voor werkzoekenden die zijn ingedeeld in fase 2 en 3 . Wanneer de knelpuntsindicator bijvoorbeeld 0,30 bedraagt, betekent dit dat 30\% van de werkzoekenden in fase 2 en 3 via een bijscholings- of begeleidingstraject aan een baan geholpen kan worden en eraan kunnen bijdragen dat de knelpunten in het betreffende segment verminderd kunnen worden.

De arbeidsmarktkrapte en de knelpuntsindicator maken het mogelijk een nadere typering te geven van de krapte op de arbeidsmarkt. Er worden drie situaties onderscheiden:

\section{Een ruime arbeidsmarkt}

Een ruime arbeidsmarkt wordt gekenmerkt door een overschot aan direct inzetbare werkzoekenden. De arbeidsmarktkrapte is kleiner dan één. Voor werkzoekenden met een grotere afstand tot de arbeidsmarkt zijn de perspectieven gering. Bijscholing of nadere begeleiding zal op korte termijn niet tot een vergroting van de arbeidsmarktkansen leiden. Aanvullende indicaties voor het ruime karakter van een arbeidsmarkt zijn een hoge werkloosheid en een hoog percentage langdurig werkzoekenden.

\section{Een krappe arbeidsmarkt met een kwantitatief tekort}

Wanneer er sprake is van een tekort aan direct inzetbare werkzoekenden, terwijl er op het betreffende arbeidsmarktsegment ook onvoldoende werkzoekenden met een wat grotere afstand tot de arbeidsmarkt beschikbaar zijn, is er sprake van een kwantitatief probleem. Er zijn eenvoudigweg te weinig werkzoekenden in het betreffende segment beschikbaar. De knelpuntsindicator is groter dan één. Dit betekent overigens ook dat de arbeidsmarktkansen voor werkzoekenden in fase 2 en 3 groot zijn. Gezien het grote aantal vacatures vergeleken met het totaal aantal werkzoekenden in dit segment is bijscholing of verdere begeleiding een bijzonder effectief middel om werkzoekenden met een grotere afstand tot de arbeidsmarkt aan het werk te helpen. Verdere aanwijzingen voor een krappe arbeidsmarkt zijn een hoge vacaturegraad en een hoog percentage langdurig openstaande vacatures.

\section{Een krappe arbeidsmarkt met een kwalitatief aansluitingsprobleem}

Wanneer er sprake is van een tekort aan direct inzetbare werkzoekenden, terwijl er voldoende werkzoekenden in fase 2 en 3 in het betreffende segment op zoek zijn naar een baan is er sprake van een kwalitatief aansluitingsprobleem. Er is weliswaar voldoende aanbod - de knelpuntsindicator is kleiner dan één - maar dit aanbod voldoet niet aan de gestelde eisen: de afstand tot de arbeidsmarkt is te groot. Vanuit de vacatureproblematiek aan de vraagzijde van de arbeidsmarkt is bijscholing of verdere begeleiding in dat geval een effectief middel. De arbeids marktkansen voor werkzoekenden in fase 2 en 3 zijn echter relatief klein. Er zijn veel werkzoekenden in fase 2 en 3 beschikbaar hetgeen betekent dat bijscholings- en begeleidingsprgramma's de werkloosheidsproblemen in dit segment niet drastisch zullen verminderen. Verdere aanwijzingen voor een krappe arbeidsmarkt zijn een hoge vacaturegraad en een hoog percentage langdurig openstaande vacatures.

Dit instrumentarium word gebruikt om de discrepanties naar beroepsgroep en naar opleidingstype in kaart te brengen. Deze maatstaven kunnen niet toegepast worden om inzicht te krijgen in de discrepanties naar bedrijfssector, aangezien werkzoekenden vaak niet naar 
bedrijfssector zijn in te delen. De arbeidsmarktkrapte naar bedrijfssector is daarom gedefinieerd als het gewogen gemiddelde van de arbeidsmarktkrapten naar beroepsgroep. De wegingsfactor wordt hierbij bepaald door het aandeel van een beroepsgroep in het totaal aantal openstaande vacatures in een sector.

\section{Discrepanties naar bedrijfssector}

De arbeidsmarktkrapte naar bedrijfssector geeft een indicatie van de mate waarin de verschillende bedrijfssectoren getroffen worden door een tekort aan direct inzetbare werkzoekenden in de arbeidssegmenten waarin zij nieuwe mensen werven. Figuur 3.6 geeft een overzicht van de arbeidsmarktkrapte per bedrijfssector in Limburg in 1997 en 1998. Uit de figuur blijkt dat er in 1997 sprake was van een ruime arbeidsmarkt. De indicator met betrekking tot de arbeidsmarktkrapte was dat jaar voor alle bedrijfssectoren kleiner dan één. Het aantal direct inzetbare werkzoekenden overtrof dus het aantal openstaande vacatures. Voor elke 100 werkzoekenden in fase 1 waren er slechts 39 openstaande vacatures beschikbaar. De situatie in 1998 is echter radicaal veranderd. Thans zijn er per 100 werkzoekenden maar liefst 222 openstaande vacatures beschikbaar. Als gevolg hiervan is in 11 van de 13 sectoren sprake van een krappe arbeidsmarkt; de indicator van de arbeidsmarktkrapte is (ruimschoots) groter dan één. Voor deze sectoren geldt dat de openstaande vacatures niet direct kunnen worden vervuld wegens een tekort aan direct inzetbare werkzoekenden. Het is in ruim één jaar dus aanzienlijk moeilijker geworden personeel te vinden om vacatures te vervullen. Hier zijn twee oorzaken voor. Enerzijds is het aantal openstaande vacatures gestegen en anderzijds is het aantal werkzoekenden in fase l afgenomen. Beide veranderingen werken in dezelfde richting en leiden in de meeste sectoren tot een personeelstekort.

De situatie is het ernstigst voor de sectoren voeding en chemie met rond vier keer zoveel openstaande vacatures als direct inzetbare werkzoekenden. Met zulke grote verschillen is het maar zeer de vraag of er voldoende werkzoekenden met een grotere afstand tot de arbeidsmarkt zijn om in deze behoefte te voorzien. De enige twee sectoren die ook in 1998 nog de kenmerken van een ruime arbeidsmarkt vertonen, zijn landbouw en visserij en energic. Bedrijven in deze sectoren hebben te maken met een aantal direct inzetbare werkzoekenden dat groter is dan het aantal openstaande vacatures. Vooral voor de sector landbouw cn visserij lijkt dit niet overeen te komen met de gegevens in tabel 3.5. Hierin is te zien dat $V B O$ landbouw en natuurlijke omgeving, BOL/BBL milieu en groene ruimte en HBO landbouw en veeteelt opleidingstypen zijn met een hoog tot zeer hoog percentage moeilijk vervulbare vacatures. Deze op het eerste gezicht paradoxale situatie kan verklaard worden, door te bedenken dat de rekruteringsproblemen zich in deze sectoren op zeer specifieke segmenten kunnen voordoen, terwijl er gemiddeld genomen geen problemen zichtbaar zijn. De geaggregeerde cijfers voor bedrijfssectoren geven nu eenmaal minder gedetailleerde informatie. Ook is het mogetijk dat de moeilijk vervulbare vacatures door de direct inzetbare werkzoekenden te weinig aantrekkelijk worden gevonden, bijvoorbeeld vanwege het tijdelijke karakter van de vacante functie (seizoensarbeid). 


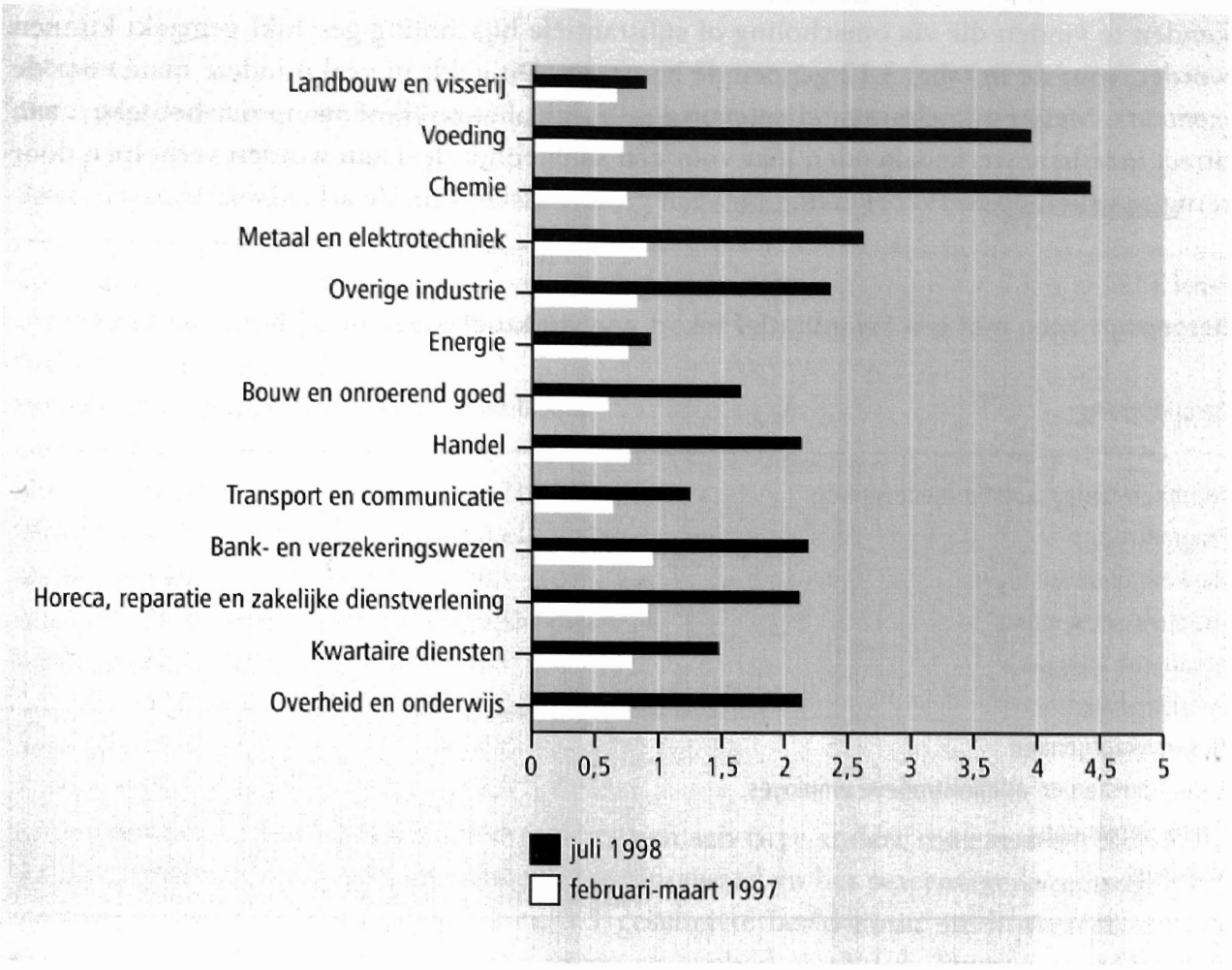

Bron: ROA

\section{Discrepanties naar beroepsgroep}

Een tekort aan direct inzetbare werkzoekenden in een specifiek arbeidsmarktsegment kan verschillende oorzaken hebben. De discrepanties op de arbeidsmarkt kunnen, zoals hierboven reeds is uiteengezet, kwantitatief of kwalitatief van aard zijn. In tabel 3.12 wordt een overzicht gegeven van de beroepsgroepen waarin er sprake is van een kwantitatief tekort. De in de tabel genoemde beroepsgroepen worden niet alleen gekenmerkt door een tckort aan direct inzetbare werkzoekenden - de indicator voor de arbeidsmarktkrapte is groter dan één - maar er is ook onvoldoende aanbod van werkzoekenden met een wat grotere afstand tot de arbeidsmarkt op het desbetreffende arbeidsmarktsegment. Deze problemen doen zich voor bij de automatiseringsberoepen programmeurs en systeemanalisten. Bij de programmeurs bijvoorbeeld is er slechts één direct inzetbare werkzoekende beschikbaar per 13 vacatures. Verder is het beeld divers, al zijn de technische beroepen oververtegenwoordigd. Gezien het kwantitatieve karakter van de aansluitingsproblematiek op dit arbeidsmarktsegment - de knelpuntsindicator is groter dan één - zijn scholingsprogramma's een bijzonder effectief middel om de werkloosheid bij deze beroepsgroepen te verminderen. Voor elke werkzoekende programmeur in fase 2 en 3 zijn er bijvoorbeeld ruim 5 vacatures beschikbaar. Om het tekort aan arbeidskrachten in deze segmenten aan te pakken, zijn bijscholingsprogramma's die gericht zijn op werkzoekenden op dit arbeidsmarktsegment die zijn 
ingedeeld in fase 2 en 3 echter niet voldoende. Aangezien de knelpuntsindicator groter is dan één, kunnen niet alle openstaande vacatures door mensen in fase 2 en 3 opgevuld worden. Werving op andere arbeidsmarktsegmenten is derhalve noodzakelijk om werkzoekenden te vínden die via omscholing of substantiële bijscholing geschikt gemaakt kunnen worden voor de in tabel 3.12 genoemde beroepen. Dit geldt in veel mindere mate voor de monteurs. Met een knelpuntsindicator van 1,02 lijkt het er alleszins op dat het tekort aan direct inzetbare werkzoekenden hier voor een aanzienlijk deel kan worden verholpen door terug te vallen op werkzoekenden met een grotere afstand tot de arbeidsmarkt.

Tabel 3.12

Beroepsgroepen met een kwantitatief tekort aan werkzoekenden in Limburg, juli 1998

Beroepsgroep

Technisch-bedrijtskundig medewerkers

Programmeurs

Werktuigbouwkundigen

Assistent accountants

Agrarische arbeiders

Systeemanalisten

Ziekenverzorgenden

Receptionisten en administratieve employés

Productieplanners

Monteurs arbeidsmarktkrapte

knelpuntsindicator

\begin{tabular}{rl}
\hline 15,50 & 5,80 \\
13,00 & 5,14 \\
7,94 & 5,21 \\
7,67 & 3,41 \\
7,06 & 1,54 \\
6,77 & 3,96 \\
5,50 & 2,40 \\
4,89 & 1,70 \\
4,86 & 1,50 \\
4,85 & 1,02 \\
\hline
\end{tabular}

Bron: ROA

Wanneer een tekort aan direct inzetbare werkzoekenden gepaard gaat met een relatief groot aantal werkzoekenden met een grotere afstand tot de arbeidsmarkt is er sprake van een kwalitatief aansluitingsprobleem. In tabel 3.13 wordt een overzicht gegeven van de beroepsgroepen waarin er sprake is van een kwalitatief aansluitingsprobleem. De in de tabel genoemde beroepsgroepen worden weliswaar gekenmerkt door een tekort aan direct inzetbare werkzoekenden, maar er zijn voldoende werkzoekenden met een wat grotere afstand tot de arbeidsmarkı beschikbaar. De nummer éen van deze tabel is de beroepsgroep conciërges. Deze beroepsgroep heeft een arbeidsmarktkrapte van 4,90 en een knelpuntsindicator van 0,31 . Deze laatste waarde geeft als gezegd aan dat het tekort aan direct bemiddelbare arbeidskrachten relatief eenvoudig kan worden gecompenseerd door de werkzoekenden met een grotere afstand tot de arbeidsmarkt. Scholings- of begeleidingsprogramma's, gericht op het verkleinen van deze afstand, zijn derhalve een effectief middel om het tekort aan werkzoekenden te verminderen. Aangezien de knelpuntsindicator kleiner is dan één, zijn er voldoende werkzoekenden in fase 2 en 3 beschikbaar om het tekort te verhelpen. Voor de werkzoekenden zelf betekent dit echter dat slechts een deel van hen op korte termijn de stap naar een volwaardige plaats op de arbeidsmarkt zal kunnen maken.

De tabel bevat een aantal elementaire beroepen en beroepen waarvoor slechts een gering kwalificatieniveau vereist is, zoals conciërges, interieurverzorgers en vakkenvullers. Het kwalitatieve karakter van de aansluitingsproblemen is met name bij deze beroepen niet 
inhoudelijk van aard. Het feit dat er een groot aantal werkzoekenden een grotere afstand tot de arbeidsmarkt heeft wordt met name door bijvoorbeeld lichamelijke (bijvoorbeeld gedeeltelijke arbeidsongeschiktheid) of sociale factoren veroorzaakt.

\section{Tabel 3.13}

\section{Beroepsgroepen met een kwalitatief aansluitingsprobleem in Limburg, juli 1998}

\section{Beroepsgroep}

\section{Conciërges \\ Chauffeurs}

Grafisch productiepersoneel

Weg-en waterbouwkundigen

Elektronicamonteurs

Interieurverzorgers

Verkopers

Metaalarbeiders

Asp. politieagenten, soldaten en beveiligingshulpkrachten Vakkenvullers

\section{arbeidsmarktkrapte knelpuntsindicator}

\begin{tabular}{ll}
\hline, 90 & 0,31 \\
3,63 & 0,78 \\
3,55 & 0,97 \\
3,50 & 0,88 \\
3,38 & 0,57 \\
3,34 & 0,43 \\
3,30 & 0,92 \\
2,94 & 0,96 \\
2,85 & 0,44 \\
2,67 & 0,39 \\
\hline
\end{tabular}

Bron: $R O A$

In de tabellen 3.2 en 3.3 is aandacht geschonken aan twee andere indicatoren voor rekruteringsproblemen op de arbeidsmarkt: de vacaturegraad en het percentage langdurig openstaande vacatures. Het in tabel 3.2 en 3.3 geschetste beeld komt sterk overeen met de conclusies die uit de confrontatie van vraag en aanbod getrokken kunnen worden. Tien beroepsgroepen komen in beide analyses naar voren als arbeidsmarktsegmenten met een grote (kwantitatieve dan wel kwalitatieve) krapte: chauffeurs, verkopers, interieurverzorgers, systeemanalisten, receptionisten en administratieve employés, programmeurs, aspirant politieagenten, soldaten en beveiligingshulpkrachten, weg-en waterbouwkundigen, technisch-bedrijfskundig medewerkers en metaalarbeiders. Deze beroepsgroepen komen voor in tabel 3.2 of tabel 3.3 én tabel 3.12 of tabel 3.13.

Dit betekent niet dat deze tien beroepsgroepen dezelfde problemen hebben, want er bestaan verschillen tussen de analyses op basis van de vacatures enerzijds en de confrontatie van vraag en aanbod anderzijds. Deze verschillen kunnen diverse oorzaken hebben. Ten eerste is het belangrijk te onthouden dat beide analyses een verschillend aspect van het probleem belichten. Met name de langdurig openstaande vacatures geven een indicatie van de wijze waarop werkgevers rekruteringsproblemen proberen te verhelpen. Wanneer het probleem tijdelijk intern wordt opgelost door bijvoorbeeld overwerk, zal de vacature blijven openstaan. Wanneer daarentegen gekozen wordt voor bijvoorbeeld het in dienst nemen van uitzendkrachten komen de rekruteringsproblemen niet tot uiting in een hoog percentage langdurig openstaande vacatures. De systeemanalisten en de receptionisten en administratieve employés zijn hiervan een goed voorbeeld. Deze beroepsgroepen kennen een gemiddelde tot hoge vacaturegraad en een tekort aan direct inzetbare werkzoekenden. Het percentage langdurig openstaande vacatures is daarentegen relatief laag (niet meer dan 'gemiddeld'), omdat via uitzendkrachten het rekruteringsprobleem op korte termijn verholpen wordt. 
Een tweede oorzaak kan gelegen zijn in de eisen die vraag en aanbod stellen. Ondanks het feit dat er voldoende werkzoekenden zijn die geacht worden direct inzetbaar te zijn, kunnen werkgevers op sommige arbeidsmarktsegmenten toch problemen hebben met het vinden van geschikte mensen, hetzij omdat deze werkzoekenden om één of andere reden toch niet aan hun wensen voldoen, hetzij omdat de banen niet aan de wensen van de werkzoekenden voldoen. Hierbij kan gedacht worden aan andere aspecten dan de inhoudelijke aansluiting tussen kwalificaties waarover de werkzoekenden beschikken en de gevraagde kwalificaties, waarop in dit rapport de nadruk ligt. Voorbeelden zijn leeftijd, de duur van het arbeidscontract, werktijden, duur van de werkweek, etc. Goede voorbeelden hiervan vormen de beveiliging waar beschikbare ervaren krachten als te duur worden beschouwd door de sector en de bouw waar bijvoorbeeld knelpunten ontstaan omdat calculators en werkvoorbereiders liever kiezen voor een baan op kantoor in plaats van een qua arbeidsomstandigheden veel minder aantrekkelijke baan in de uitvoerende sfeer.

Een derde oorzaak zou gelegen kunnen zijn in de heterogeniteit van de beroepsgroepen. De problemen kunnen zich in een zeer specifiek segment binnen deze beroepsgroep voordoen. Deze problemen leiden tot een hoog percentage langdurig openstaande vacatures, maar komen niet tot uiting in de arbeidsmarktkrapte. Een voorbeeld vormen de gespecialiseerde verpleegkundigen. Er is vooral een tekort aan intensive-care en kinderverpleegkundigen, terwijl er voor andere specialisaties voldoende aanbod beschikbaar is. Ook binnen bedrijfssectoren kunnen tekorten op specifieke plekken optreden. Ook hier vormt de zorgsector een goed voorbeeld. Verschillen in de CAO's zorgen er bijvoorbeeld voor dat met name verzorgingshuizen veel moeite hebben personeel te vinden. Daarnaast dient gewezen te worden op de aantrekkingskracht van het werken bij grotere bedrijven, waardoor bij knelpunten op de arbeidsmarkt vooral kleine bedrijven meer moeite hebben met het vinden van geschikt personeel. Bovendien kunnen grotere bedrijven rekruteringsproblemen beter opvangen door gebruik te maken van hun interne arbeidsmarkt. Ten slotte kan er sprake zijn van regionale fricties. Terwijl er in Limburg als geheel op een bepaald arbeidsmarktsegment geen tekort is, kan dit in specifieke regio's wel het geval zijn.

De gegevens van vorig jaar toonden aan dat er voor verreweg het merendeel van de beroepsgroepen sprake was van een ruime arbeidsmarkt. Dat resulteerde ook in arbeidsmarktkrapten voor de verschillende bedrijfssectoren die allemaal kleiner dan één waren (zie figuur 3.6). In groot contrast met vorig jaar, zijn er nu slechts twee beroepsgroepen waarbij er (voorlopig) geen sprake lijkt te zijn van arbeidsmarktkrapte, namelijk docenten en bedrijfshoofden horeca. Er zijn voor deze beroepsgroepen voldoende werkzoekenden in fase $1 \mathrm{om}$ de openstaande vacatures te vervullen. Ook hier kan er desondanks sprake zijn van rekruteringsproblemen. Opnieuw worden deze dan niet veroorzaakt door een gebrekkige vakinhoudelijke aansluiting tussen vraag en aanbod, maar door één (of meer) van de drie bovengenoemde oorzaken. Voor docenten zij vermeld dat de data weinig conclusies rechtvaardigen, daar de gegevens voor alle docenten zijn geaggregeerd. Dat er voor deze groep als geheel voldoende werkzoekenden in fase I beschikbaar zijn, wil niet zeggen dat er voor specifieke docenten, bijvoorbeeld docenten exacte vakken, geen knelpunten kunnen bestaan. 


\section{Uitgelicht: Monteurs}

De werkgelegenheid in Limburg voor de beroepsgroep monteurs is met 17.000 werkenden gemiddeld over 1996-1997 relatief groot (tabel 1.10 van de Statistische Bijlage). Een eerste indicatie voor de huidige arbeidsmarkt voor monteurs in Limburg vormt de vacaturemarkt. In dit verband worden in dit rapport twee indicatoren gebruikt; de vacaturegraad (het aantal openstaande vacatures per 1.000 werkenden) en het percentage moeilijk vervulbare vacatures. De beroepsgroep monteurs heeft met 125 vacatures op 17.000 werkenden een zeer lage vacaturegraad. Het percentage langdurig openstaande vacatures (langer dan 3 maanden) is met $30 \%$ gemiddeld te noemen (tabel 2.2 van de Statistische Bijlage). Naast de vacaturemarkt biedt ook het werkzoekendenbestand een indicatie van de arbeidsmarktpositie van monteurs. De hiervoor relevante informatie kan men vinden in tabellen 2.4 en 2.5 van de Statistische Bijlage. Het aanbod bestaat uit 175 niet-werkende werkzoekende monteurs. Dit aantal wordt als 'laag' getypeerd, maar het percentage langdurig zoekenden is met $63 \%$ wel aan de hoge kant. Van de niet-werkende werkzoekenden is slechts $16 \%$ direct inzetbaar (fase 1). De rest heeft een grotere afstand tot de arbeidsmarkt.

$\mathrm{Nu}$ in het voorgaande vraag en aanbod in kaart is gebracht, kunnen we via een confrontatie inzicht krijgen in de actuele knelpunten op de arbeidsmarkt voor monteurs in Limburg. Het tekort dan wel overschot aan direct inzetbare werkzoekenden wordt weergegeven door de arbeidsmarktkrapte. Deze is gedefinieerd als de verhouding tussen het aantal openstaande vacatures en het aantal werkzoekenden in fase 1. Een arbeidsmarktkrapte groter dan één duidt op een tekort aan direct inzetbare werkzoekenden. Voor monteurs geldt een arbeidsmarktkrapte van 4,85 (tabel 2.11 van de Statistische Bijlage). Dit betekent dat er voor elke direct inzetbare werkzoekende bijna 5 vacatures beschikbaar zijn. Is dit tekort nu kwantitatief of kwalitatief van aard? Gezien het tekort aan direct inzetbare werkzoekenden dient een groot deel van de openstaande vacatures te worden opgevuld door werkzoekenden met een grotere afstand tot de arbeidsmarkt. De knelpuntsindicator geeft aan in hoeverre deze werkzoekenden in fase 2 en 3 beschikbaar zijn. Een knelpuntsindicator groter dan één impliceert een kwantitatief tekort; een knelpuntsindicator kleiner dan één betekent dat het tekort kwalitatief van aard is. De beroepsgroep monteurs heeft een knelpuntsindicator van 1,02 (tabel 2.11 van de Statistische Bijlage). De arbeidsmarkt voor monteurs kan dus getypeerd worden als een krappe arbeidsmarkt met een kwantitatief tekort: er is een tekort aan direct inzetbare werkzoekenden en ook onvoldoende aanbod van werkzoekenden met een wat grotere afstand tot de arbeidsmarkt. Gezien het kwantitatieve karakter van de aansluitingsproblematiek zijn scholingsprogramma's gericht op de werkzoekenden in fase 2 en 3 een bijzonder effectief middel om de werkloosheid te verminderen. Voldoende is dit echter niet. Wanneer alle werkzoekenden in fase 2 en 3 bijgeschoold worden, dan nog blijven er vacatures over. Werving op andere arbeidsmarktsegmenten is derhalve noodzakelijk om de resterende vacatures op te kunnen vullen. Maar daar de knelpuntsindicator voor monteurs erg dicht bij 1 ligt, lijkt het er alleszins op dat het tekort aan direct inzetbare werkzoekenden voor een zeer aanzienlijk deel kan worden verholpen door terug te vallen op werkzoekenden in fase 2 en 3. 


\section{Discrepanties naar opleidingstype}

Ook naar opleidingstype kunnen de discrepanties in kaart gebracht worden. In tabel 3.14 wordt een overzicht gegeven van de opleidingstypen waarvoor er een kwantitatief tekort aan werkzoekenden bestaat. De in deze tabel genoemde opleidings typen worden niet alleen gekenmerkt door een tekort aan direct inzetbare werkzoekenden - de indicator voor de arbeidsmarktkrapte is groter dan één - maar ook is er onvoldoende aanbod van werkzoekenden met een wat grotere afstand tot de arbeidsmarkt. De problemen doen zich voor bij een meerderheid van de opleidingen. De top tien toont zeer diverse opleidingstypen. Hogere en lagere opleidingstypen, commerciële en technische opleidingen, maar ook $B O L / B B L$ en $H B O$ landbouw en veeteelt. Uitschieter is de opleiding HBO accountancy en bedrijfseconomie. Dit opleidingstype wordt bijvoorbeeld gekenmerkt door het feit dat er slechts één ongeveer werkzoekende beschikbaar is per 28 openstaande vacatures. Dit negatieve beeld wordt nog versterkt door de eveneens zeer hoge knelpuntsindicator. De aansluitingsproblematiek is derhalve vooral kwantitatief van aard. Dit betekent dat scholingsprogramma's een bijzonder effectief middel zouden kunnen zijn om de werkloosheid onder mensen met de in tabel 3.14 genoemde opleidingsachtergrond te verminderen. Voor elke werkzoekende in fase 2 en 3 met de opleidingsachtergrond $H B O$ accountancy en bedrijfseconomie zijn er maar liefst bijna 25 openstaande vacatures beschikbaar. Om het tekort aan arbeidskrachten in deze en andere soortgelijke segmenten aan te pakken zijn bijscholingsprogramma's gericht op deze werkzoekenden echter niet toereikend. De knelpuntsindicator is voor de bovengenoemde opleidingstypen groter dan één, wat betekent dat niet alle openstaande vacatures door de werkzoekenden in fase 2 en 3 op het desbetreffende arbeidsmarktsegment opgevuld kunnen worden. Werving op andere arbeidsmarktsegmenten is noodzakelijk om werkzoekenden te vinden die via omscholing geschikt gemaakt kunnen worden voor de banen waaraan de vraag naar hierboven genoemde opleidingen ten grondslag ligt.

Tabel 3.14

Opleidingstypen met een kwantitatief tekort aan werkzoekenden in Limburg, juli 1998

Opleidingstype

HBO accountancy en bedrijfseconomie

BOL/BBL operationele techniek

$\mathrm{HBO}$ elektrotechniek

VBO vervoer

BOL/BBL landbouw en veeteelt

$\mathrm{HBO}$ landbouw en veeteelt

VBO beveiliging

BOL/BBL milieu en groene ruimte

BOL/BBL horeca

BOL/BBL handel arbeidsmarktkrapte knelpuntsindicator

$\begin{array}{rr}27,81 & 24,48 \\ 20,00 & 4,22 \\ 17,55 & 7,43 \\ 15,11 & 7,47 \\ 12,87 & 5,74 \\ 12,50 & 7,67 \\ 11,71 & 2,83 \\ 11,67 & 1,78 \\ 9,36 & 3,86 \\ 9,10 & 4,43\end{array}$

Bron: $R O A$ 
Wanneer een tekort aan direct inzetbare werkzoekenden gepaard gaat met een relatief groot aantal werkzoekenden met een wat grotere afstand tot de arbeidsmarkt is er sprake van een kwalitatief aansluitingsprobleem. In tabel 3.15 wordt een overzicht gegeven van de opleidingstypen die gekenmerkt worden door een kwalitatief aansluitingsprobleem: de in de tabel genoemde opleidingstypen worden weliswaar gekenmerkt door een tekort aan direct inzetbare werkzoekenden, maar er zijn voldoende werkzoekenden met een wat grotere afstand tot de arbeidsmarkt beschikbaar (herkenbaar aan een knelpuntsindicator kleiner dan één). Scholings- of begeleidingsprogramma's, gericht op het verkleinen van deze afstand, zijn in dit geval een effectief middel om het tekort aan direct inzetbare werkzoekenden te verminderen. Er zijn voldoende werkzoekenden in fase 2 en 3 beschikbaar om het tekort te verhelpen. Voor de werkzoekenden zelf betekent dit echter dat slechts een klein deel op korte termijn de stap naar een volwaardige plaats op de arbeidsmarkt zal kunnen maken. Technische en verzorgende BOL/BBL-opleidingen hebben de overhand in tabel 3.15. Voor de verplegende en verzorgende opleidingen geldt dat het grote potentieel aan werkzoekenden met een min of meer grote afstand tot de arbeidsmarkt, voornamelijk uit (tijdelijk uit de arbeidsmarkt getreden) vrouwen bestaat. Deze groep werkzoekenden vindt doorgaans redelijk gemakkelijk zijn weg naar de arbeidsmarkt terug en kan dus op termijn een oplossing bieden voor het tekort aan direct inzetbare werkzoekenden. Van de hogere opleidingstypen staat in deze tabel alleen HBO leraar basisonderwijs. Over het algemeen worden de hogere opleidingen gekenmerkt door een kwantitatief tekort.

Tabel 3.15

Opleidingstypen met een kwalitatief aansluitingsprobleem in Limburg, juli 1998

Opleidingstype

BOL dokters-, tand- en dierenartsassistent

VBO bouwtechniek

$B O L B B L$ verzorging

BOL/BBL verpleegkunde

BOL/BBL secretarieel

$\mathrm{BOL} / \mathrm{BBL}$ uiterlijke verzorging

BOL/BBL mech. techniek en werktuigbouwk.

$\mathrm{HBO}$ leraar basisonderwijs

$B O L$ verzekeringswezen

BOL/BBL grafische techniek arbeidsmarktkrapte knelpuntsindicator

\begin{tabular}{ll}
\hline 3,57 & 0,75 \\
3,47 & 0,71 \\
3,19 & 0,70 \\
3,11 & 0,58 \\
3,10 & 0,89 \\
3,00 & 0,64 \\
2,87 & 0,95 \\
2,75 & 0,86 \\
2,50 & 0,80 \\
2,00 & 0,33 \\
\hline
\end{tabular}

Bron: $R O A$

In de tabellen 3.4 en 3.5 zijn twee aanvullende indicatoren voor rekruteringsproblemen belicht: de vacaturegraad en het percentage langdurig openstaande vacatures. Zoals reeds eerder is opgemerkt geven de drie in deze paragraal gepresenteerde indicatoren elk een specifiek aspect van de aansluitingsproblematiek weer. Het in de tabellen 3.4 en 3.5 geschetste beeld komt wederom overeen met de conclusies die uit de confrontatie van vraag en aambod getrokken kunnen worden. Dit is bijvoorbeeld het geval bij de opleidingstypen VBO bouwtechniek, HBO elektrotechniek, HBO accountancy en bedrijfseconomie, BOLABI mechanische techniek en werktuigbouwkunde, BOL/BBL handel, BOL/BBL horeca en $B O L / B B I$ 
uiterlijke verzorging. Deze opleidingen worden niet alleen gekenmerkt door een tekort aan direct inzetbare werkzoekenden, maar eveneens door een hoge vacaturegraad. De opleidingstypen $H B O$ landbouw en veeteelt, $B O L / B B L$ milieu en groene ruimte, BOL/BBL operationele techniek, $B O L / B B L$ verpleegkunde en $H B O$ elektrotechniek kennen zowel een tekort aan direct inzetbare werkzoekenden als een hoog percentage moeilijk vervulbare vacatures.

Evenals voor de beroepsgroepen geldt dat er dit jaar slechts een klein aantal opleidingstypen is waarvoor er sprake is van een ruime arbeidsmarkt. Dit zijn Basisonderwijs, MAVO, $V B O$ administratie en handel, HAVO/VWO en BOL/BBL informatica. Zeer opvallend is de ruime arbeidsmarkt voor $B O L / B B L$ informatica. Zoals reeds eerder gesteld zou dit veroorzaakt kunnen zijn door het grote aantal werkzoekenden dat zijn arbeidsmarktkansen tracht te vergroten door het volgen van opleidingen en cursussen op het gebied van automatisering. De vraag is echter of zij hiermee een volwaardige kans maken op een baan in een automatiseringsberoep. Gezien het feit dat er bijvoorbeeld bij de beroepsgroep programmeurs sprake is van een zeer krappe arbeidsmarkt zal dit waarschijnlijk niet het geval zijn. 


\section{De Limburgse arbeidsmarkt in 1999}

\subsection{Inleiding}

In dit hoofdstuk zal aandacht worden besteed aan de situatie op de Limburgse arbeidsmarkt in 1999; het gaat hier dus om prognoses van de arbeidsmarktontwikkelingen op de korte termijn. Deze prognoses maken het mogelijk dat eventuele knelpunten bij beroepen en opleidingen tijdig kunnen worden gesignaleerd. Dit vergroot de transparantie van de (regionale) arbeidsmarkt voor diverse gebruiksdoelen. Zo stellen de prognoseresultaten werkgevers in staat bij het personeelsbeleid te anticiperen op de verwachte knelpunten op de arbeidsmarkt. Hierbij kan het zowel gaan om het wervings- en selectiebeleid als om het interne scholingsbeleid, het eventuele outplacementbeleid e.d. Een tweede doelgroep vormen de organisaties die betrokken zijn bij het scholingsbeleid dat als belangrijk sturend element kan fungeren om vraag en aanbod dichter bij elkaar te brengen. In hoofdstuk 6 van dit rapport zal hier nader op worden ingegaan.

Aansluitend zal allereerst een beschrijving worden gegeven van het prognosemodel dat door het ROA wordt gebruikt om tot de voorspellingen te komen die de basis van dit hoofdstuk vormen. Vraag- en aanbodprognoses komen vervolgens in de paragrafen 4.2 en 4.3 aan bod. In paragraaf 4.2 worden de cijfers gepresenteerd voor de uitbreidings- en vervangingsvraag en de daaruit resulterende baanopeningen. Daarna wordt in paragraaf 4.3 aandacht geschonken aan de instroom van schoolverlaters op de arbeidsmarkt. Vervolgens wordt in paragraaf 4.4 door het vergelijken van de verwachte vraag en het verwachte aanbod voor de verschillende beroepen en opleidingen een indicatie gegeven van de knelpunten in de personeelsvoorziening waarmee werkgevers naar verwachting in 1999 zullen worden geconfronteerd. Tevens kan dan voor degenen die in 1999 op de arbeidsmarkt zullen uitstromen een beeld worden geschetst van de verwachte perspectieven.

Dit hoofdstuk laat zien dat er ook in 1999 op brede schaal een krapte op de arbeidsmarkt verwacht wordt. Dit betekent dat werkgevers ook in 1999 grote moeite zullen hebben om geschikt personeel te vinden. Alleen voor de productiemedewerkers en voor een aantal relatief kleine beroepsgroepen zoals de agrarische vakkrachten, de schippers en conducteurs en de verpleeghulpen en leerling-verpleeghundigen worden (vrijwel) geen knelpunten in de personeelsvoorziening verwacht in 1999. De keerzijde is dat de perspectieven voor nieuwkomers op de arbeidsmarkt over het algemeen goed zullen zijn. Een vergelijking van de prognoses voor 1999 en de vorig jaar gemaakte prognoses voor 1998 laat duidelijk zien daı de verkrapping op de Limburgse arbeidsmarkt steeds verder toeneemt en zich bovendien op steeds meer segmenten van de arbeidsmarkt manifesteert. Voor 1998 werd voor 30 van de 52 opleidingstypen een goed tot zeer goed perspectief verwacht. Voor 1999 zal dit aantal naar verwachting stijgen tot maar liefst 33 opleidingstypen. Op MBO-niveau komt de verkrapping nog veel sterker tot uiting. Werd voor 1998 voor 26 van 35 opleidingstypen een (zeer) goed perspectief verwacht; voor 1999 zal voor de nieuwkomers op de arbeidsmarkt van 29 opleidingstypen het perspectief goed tot zeer goed zijn. Een minder perspectief wordt derhalve met name verwacht voor mannen met een opleiding op VBO-niveau. Ook het perspectief voor 1999 van mensen met een algemene opleiding (MAVO, HAVO of $V W O)$ is minder gunstig. 


\section{Het prognosemodel}

Bij het maken van de korte-termijnprognoses voor de Limburgse arbeidsmarkt is gebruik gemaakt van een stroomcijfer-aanpak die nauw aansluit bij de methode zoals die door het ROA in het kader van het landelijk Informatiesysteem Onderwijs-Arbeidsmarkt is ontwikkeld $^{22}$. Hierbij worden prognoses gemaakt van de werk gelegenheidsontwikkelingen en van de stromen van en naar de arbeidsmarkt in een bepaalde toekomstige periode. Deze benadering heeft als voordeel dat de processen in kaart worden gebracht die van belang zijn voor de ontwikkeling van vraag en aanbod op de arbeidsmarkt. Bovendien wordt op deze manier vermeden dat gebruik moet worden gemaakt van de over het algemeen sterk fluctuerende vacaturecijfers wat vaak tot grote voorspelfouten leidt. De prognoses voor Limburg worden opgesteld voor in totaal 65 beroepsgroepen en 56 opleidingstypen ${ }^{23}$.

Figuur 4.1 geeft een overzicht van het prognosemodel. De stroomgrootheid die van belang is voor de vraagzijde van de arbeidsmarkt is het aantal baanopeningen. Baanopeningen kunnen voortkomen uit uitbreidingsvraag of vervangingsvraag. De uitbreidingsvraag geeft de ontwikkeling van de werkgelegenheid in een bepaalde beroepsgroep of voor een bepaald opleidingstype weer. De prognoses voor de uitbreidingsvraag bouwen voort op de regionale werkgelegenheidsprognoses voor bedrijfssectoren van TNO/Inro ${ }^{24}$. Omdat binnen een bedrijfssector bepaalde beroepsgroepen zich sneller ontwikkelen dan anderen, vertaalt het ROA deze bedrijfssectorontwikkelingen naar de uitbreidingsvraag per beroepsgroep. De ontwikkelingen in de beroepsgroepenstructuur binnen bedrijfssectoren blijken in de praktijk slechts in beperkte mate per regio te verschillen. Daarom is er voor gekozen de verschuivingen in de beroepenstructuur van de werkgelegenheid in de verschillende bedrijfssectoren te baseren op landelijke ontwikkelingen. Dit heeft als belangrijk voordeel dat de voorspellingen gebaseerd zijn op meer betrouwbare data. Vervolgens wordt bepaald welke implicaties de voorspelde groei van de werkgelegenheid in de verschillende beroepsgroepen heeft voor de uitbreidingsvraag per opleidingstype. Ook hierbij wordt gebruik gemaakt van een prognose van de landelijke ontwikkeling in de gevraagde kwalificaties binnen de verschillende beroepsgroepen. De uitbreidingsvraag per opleidingstype heeft betrekking op het aantal personen met een bepaalde opleidingsachtergrond dat werkgevers zouden willen aannemen. De feitelijke ontwikkeling van het aantal werkenden per opleidingstype zal hier van kunnen afwijken door de invloed van de ontwikkeling van het aanbod op de schaarsteverhoudingen en de als gevolg daarvan optredende substitutieprocessen.

22 Researcheentrum voor Onderwijs en Arbeidsmarkt, De arbeidsmarkt naar opleiding en beroep tot 2002, ROA-1997/7 en Methodick Arbcidsmarktprognoses en -indicatoren 1997-2002, ROA-W-1997/6, Maastricht.

23 De prognoses per beroepsgroep worden opgesteld voor de elementaire, lagere en middelbare beroepen, terwijl dit bij de opleidingstypen het VBO- en MBO-niveau betreft. Twee argumenten kunnen voor deze beperkingen worden gegeven. Vanuit theoretisch oogpunt kan worden gesteld dat de arbeidsmarkı voor de hogere beroepen en opleidingen een meer landelijk karakter heeft. Vanuit praktisch oogpunt zijn deze beperkingen ingegeven door het feit dat regionale cijfers betreffende de onderwijsdeelname voor de hogere opleidingen vooralsnog niet beschikbaar zijn.

2+ TNO/Inro, Regionale arbeidsmarktprognose 1998-2003, Delft, 1998. 
Figuur 4.1

Globale opzet prognosemodel

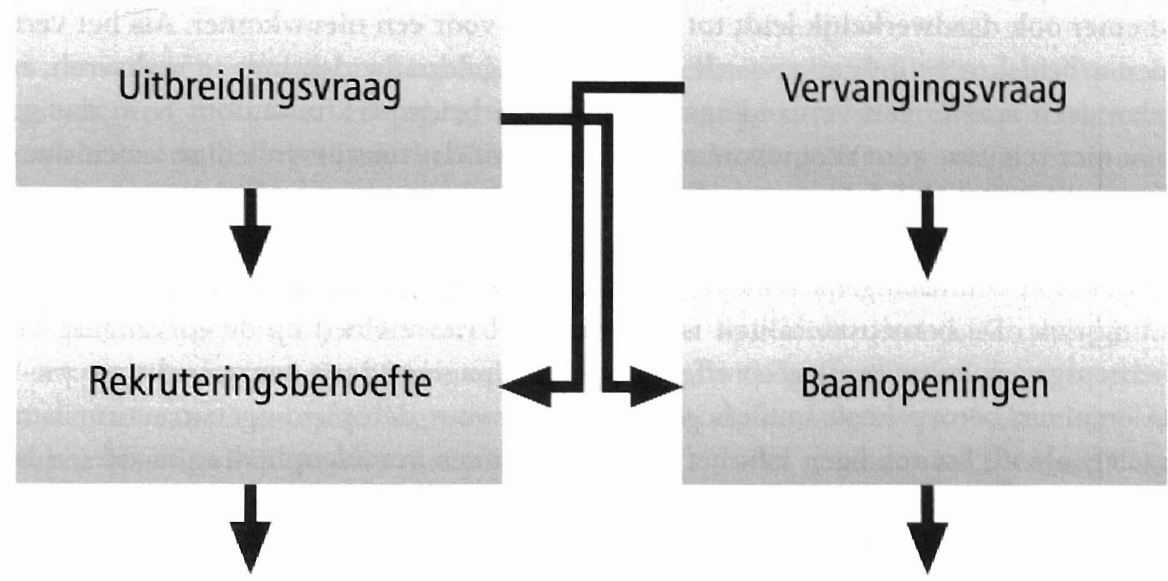

Knelpunten in de personeelsvoorziening

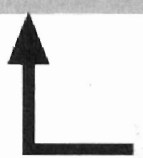

Nieuw aanbod
Arbeidsmarktperspectieven voor nieuwkomers
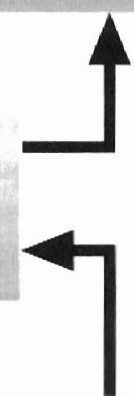

Direct bemiddelbare werkzoekenden Instroom van schoolverlaters 
Daarnaast ontstaan baanopeningen door de vervangingsvraag. Deze vervangingsbehoefte ontstaat door het vertrek van personeel vanwege - al dan niet vervroegde - pensionering, arbeidsongeschiktheid, tijdelijke terugtreding van de arbeidsmarkt, beroepsmobiliteit, e.d. Er wordt overigens alleen van vervangingsvraag gesproken voor zover het vertrek van een werknemer ook daadwerkelijk leidt tot een vacature voor een nieuwkomer. Als het vertrek van een arbeidskracht gebruikt wordt om een werkgelegenheidskrimp te realiseren, is er derhalve geen sprake van vervangingsvraag. Deze arbeidsmarktuitstroom is in dat geval immers niet relevant voor nieuwkomers. Dit betekent dat niet de volledige arbeidsmarktuitstroom daadwerkelijk leidt tot vervangingsvraag.

Bovendien is er een belangrijk verschil tussen de vervangingsvraag per beroepsgroep en per opleidingstype. De beroepsmobiliteit is namelijk wel van invloed op de vervangingsvraag per beroepsgroep, maar heeft geen effect op de vervangingsvraag per opleidingstype. Het veranderen van beroep heeft immers geen gevolgen voor de opleidingenstructuur van de werkgelegenheid. Daarentegen kan het afronden van een vervolgopleiding naast een baan betekenen dat een werkende in feite uitstroomt naar een ander opleidingstype. In dat geval is er sprake van een vervangingsvraag bij het opleidingstype waartoe de vooropleiding van deze werkende wordt gerekend.

Aangezien gedetailleerde stroomcijfers over de mobiliteit onvoldoende beschikbaar zijn, worden met behulp van standcijfers geslachts- en leeftijdsspecifieke netto verloopcoëfficiënten bepaald. Deze worden vervolgens gerelateerd aan de leeftijdsopbouw van de werkenden per beroepsgroep en opleidingstype. Evenals bij de uitbreidingsvraag wordt bij de vervangingsvraagprognose niet op regionaal niveau een specifieke analyse gemaakt van de verloopcoëfficiënten. De verwachte landelijke coëfficiënten worden geprojecteerd op de geslachts- en leeftijdsopbouw van de regionale werkgelegenheid. Op deze wijze wordt er dus expliciet rekening gehouden met de feitelijke leeftijdsopbouw van de werkenden per beroepsgroep en opleidingstype in Limburg.

Bij een toename van de werkgelegenheid vormen de uitbreidingsvraag en de vervangingsvraag tezamen het totale aantal baanopeningen voor nieuwkomers op de arbeidsmarkt. Bij krimpende werkgelegenheid kan er vanzelfsprekend alleen sprake zijn van baanopeningen vanwege de vervangingsvraag. Het aantal baanopeningen kan overigens verschillen van het totale aantal vacatures. Het belangrijkste verschil wordt veroorzaakt door de baan-baanmobiliteit van werkenden. Deze baan-baan-mobiliteit op de externe of de bedrijfsinterne arbeidsmarkt leidt tot zogenaamde vacatureketens, waarbij iedere werkende die in een andere baan wordt aangenomen weer een nieuwe vacature achterlaat. Deze baan-baanmobiliteit levert daardoor geen nieuwe banen op voor nieuwkomers op de arbeidsmarkt.

Tegenover de totale vraag naar nieuwkomers staat het verwachte aanbod van nieuwkomers, bestaande uit de toekomstige instroom van schoolverlaters in de prognoseperiode en het aan het begin van de prognoseperiode nog boven de markt zwevende aanbod van niet-werkende werkzoekenden met een kleine afstand tot de arbeidsmarkt. Daarbij is de afstand tot de arbeidsmarkt bepaald met behulp van het faseringsmodel van Arbeidsvoorziening. Werkzoekenden in fase 1 worden als direct bemiddelbaar beschouwd. Daarentegen wordt verondersteld dat werkzoekenden in fase 2 en hoger op dit moment geen serieuze concurrenten vormen voor school verlaters. De prognoses van de instroom van schoolverlaters per 
opleidingstype zijn in belangrijke mate gebaseerd op de Referentieramingen 1997 en 1998 van het Ministerie van Onderwijs, Cultuur en Wetenschappen. Door het ROA zijn deze prognoses nader verbijzonderd en aangevuld met prognoses van de doorstroom naar het niet-reguliere onderwijs.

Door de verwachte vraag- en aanbodstromen met elkaar te confronteren wordt per opleidingstype een indicatie verkregen van de toekomstige arbeidsmarktperspectieven voor nieuwkomers op de arbeidsmarkt. De betreffende indicator geeft aan welke vraag-aanboddiscrepantie er per opleidingstype te verwachten is. Een aanbodoverschot impliceert echter niet vanzelfsprekend dat de betreffende groep werkloos zal worden en een aanbodtekort betekent niet automatisch dat er sprake zal zijn van openstaande vacatures. In de praktijk blijkt dat werkgevers bij een overschot aan hoger opgeleiden hun eisen aanpassen en mensen aannemen met een hogere opleidingachtergrond dan aanvankelijk gevraagd werd. Voor degenen met een opleiding waarvoor het aanbod de vraag overtreft, betekent dit dat zij vaker beneden hun niveau moeten werken, een minder goed contract krijgen, slechter beloond worden of vaker genoegen nemen met part-time werk, terwijl men liever een fulltime betrekking had. Omgekeerd zal bij een tekortschietend aanbod de positie van degenen met de betreffende achtergrond verbeteren. Zij hoeven in dat geval geen genoegen te nemen met een functie op een lager niveau, een lagere beloning, e.d.

De vraag-aanbod-confrontatie geeft voor elk opleidingstype ook een indicatie van de toekomstige knelpunten in de personeelsvoorziening van dat type. Daarbij bepalen de uitbreidings- en vervangingsvraag, tezamen met de aan het begin van de prognoseperiode openstaande vacatures, de rekruteringsbehoefte per opleidingstype. Bij krimpende werkgelegenheid voor een bepaald opleidingstype wordt deze rekruteringsbehoefte op een andere wijze berekend dan het aantal baanopeningen voor nieuwkomers op de arbeidsmarkt, omdat er vanuit het perspectief van de werkgevers de mogelijkheid bestaat de rekruteringsbehoefte te verkleinen door de uitstroom van zittend personeel te verminderen. Zeker wanneer werkgevers geconfronteerd worden met een krappe arbeidsmarkt voor een bepaald opleidingstype, zullen zij waarschijnlijk vaak van deze mogelijkheid gebruik maken ${ }^{23}$.

Ook voor de verschillende beroepsgroepen kunnen knelpunten in de personeelsvoorziening worden bepaald door de verwachte vraagstromen te confronteren met de verwachte aanbodstromen. Ook het verwachte aanbod per beroepsgroep bestaat uit twee componenten: de instroom van schoolverlaters en de boven de markı zwevende werkzoekenden met een kleine afstand tot de arbeidsmarkt. De verwachte instroom per beroepsgroep is bepaald door de instroom per opleidingstype te vertalen naar beroepsgroe ${ }^{26}$.

25 Opgemerkt dient te worden dat in het prognosemodel vooralsnog geen rekening is gehouden met (iniernationale) pendel.

26 Deze vertaling is gebaseerd op de allocatie van schoolverlaters met cen specifieke opleidingsachtergrond over de verschillende beroepsgroepen zoals die uit de schoolverlatersenquêtes van het ROA naar voren komt. Uit oogpunt van betrouwbaarheid is de allocatie over beroepsgroepen gebaseerd op landelijke cijfers. 


\subsection{Uitbreidingsvraag, vervangingsvraag en baanopeningen}

\section{Uibreidingsvraag naar beroepsgroep}

In tabel 4.1 wordt een overzicht gegeven van de beroepsgroepen waarvoor de verwachte uitbreidingsvraag in 1999 het grootst is. Het gaat hier om relatieve cijfers, d.w.z. de ontwikkelingen zijn gerelateerd aan de werkgelegenheid in de betreffende beroepsgroep ${ }^{27}$. Voor al deze beroepsgroepen ligt de verwachte uitbreidingsvraag aanzienlijk hoger dan de gemiddelde werkgelegenheidsgroei in Limburg van $2,2 \%$. Van de genoemde beroepen liggen er zeven op middelbaar of hoger niveau. Tussen de beroepen bestaat verder weinig samenhang in de zin dat ze eenduidig aan een bepaalde sector zouden kunnen worden gerelateerd. Met uitzondering van de organisatie-adviseurs en de accountants werd voor alle in de tabel genoemde beroepsgroepen ook bij de vorig jaar opgestelde prognoses voor 1998 een erg hoge uitbreidingsvraag verwacht.

Tabel 4.2 laat zien welke beroepen naar verwachting de kleinste uitbreidingsvraag zullen hebben in 1999. Ook hier kan weer een zekere diversiteit worden geconstateerd in de zin dat de genoemde beroepen verschillend van niveau en richting zijn. De slechte vooruitzichten voor de agrarische bedrijfshoofden zijn eenvoudig te verklaren door de bedrijfsbeëindigingen en saneringen in de landbouwsector. Van genoemde beroepen kwamen er overigens reeds vijf in de tabel van 1998 voor; dit geldt echter niet voor de therapeuten en verpleegkundigen, de productiemedewerkers en de monteurs.

\section{Tabel 4.1}

Beroepsgroepen met relatief de grootste uitbreidingsvraag in Limburg in 1999, in procenten van de werkgelegenheid

Beroepsgroep

Organisatie-adviseurs

Productieplanners

Accountants

Kantoorhulpen, inpakkers en colporteurs

Ziekenverzorgenden

Boekhouders en secretaresses

Systeemanalisten

Activiteitenbegeleiders en medewerkers arbeidsbemiddeling

$\% \quad$ typering

11,7

11,2

8,1 erg hoog

erg hoog

erg hoog

erg hoog erg hoog erg hoog erg hoog erg hoog

Bron: ROA

27 Opgemerkt dient te worden dat in de in dit hoofdstuk gepresenteerde tabellen alleen beroepsgroepen en opleidingstypen zijn opgenomen waarin in Limburg meer dan 2.000 mensen werkzaam zijn. Voor de kleinere beroepsgroepen en opleidingstypen worden, in het licht van de beperkte betrouwbaarheid van de data, alleen kwalitatieve typeringen van de prognoseresultaten gepresenteerd. Zie voor een volledig overzicht hoofdstuk 3 van de Statistische Bijlage. 
Tabel 4.2

Beroepsgroepen met relatief de kleinste uitbreidingsvraag in Limburg in 1999, in procenten van de werkgelegenheid

Beroepsgroep

Agrarische bedrijfshoofden

Receptionisten en administratieve employés

Politie-agenten, onderofficieren en beveiligingsemployés

Docenten talen en expressie

Therapeuten en verpleegkundigen

Mechanisch operators

Productiemedewerkers

Monteurs
$\%$

$-3,0$

$-0,9$

$-0,7$

$-0,3$

$-0,1$

0,0

0,3

0,4 typering

erg laag

erg laag

erg laag

laag

laag

laag

laag

laag

Bron: ROA

\section{Uitbreidingsvraag naar opleidingstype}

Tabel 4.3 schetst een beeld van de opleidingstypen die voor 1999 naar verwachting de grootste uitbreidingsvraag zullen laten zien. Voor al deze opleidingstypen ligt de verwachte uitbreidingsvraag aanzienlijk hoger dan de gemiddelde werkgelegenheidsgroei in Limburg van $2,2 \%$. Hierbij gaat het vooral om technische en economisch-administratieve opleidingen. Wel bestaat er tussen deze groepen een verschil: Bij de technische opleidingen laten vooral de opleidingen op MBO-niveau een sterke groei zien, terwijl bij de economische opleidingen de grootste werkgelegenheidsgroei op HBO/WO-niveau optreedt.

In tabel 4.4 wordt een overzicht gegeven van de opleidingstypen die naar verwachting voor 1999 de sterkste krimp laten zien. De sterkste werkgelegenheidsdaling doet zich voor bij opleidingen op VBO-niveau of lager. Dit illustreert de eerder genoemde upgrading van de gevraagde kwalificaties op de arbeidsmarkı waardoor voor veel functies een VBO-diploma niet langer toereikend is.

\section{Tabel 4.3}

Opleidingstypen met relatief de grootste uitbreidingsvraag in Limburg in 1999, in procenten van de werkgelegenheid

\begin{tabular}{lcc} 
Opleidingstype & $\%$ & typering \\
\hline WO econom(-etr)ie & 8,0 & erg hoog \\
HBO commerciële economie & 6,4 & erg hoog \\
BOL/BBL procestechniek & 5,5 & hoog \\
BOL sociaal-cultureel & 5,0 & hoog \\
BOL/BBL motorvoertuigentechniek & 4,9 & hoog \\
BOL/BBL secretariaat & 4,8 & hoog \\
HBO (Fysio-)therapie & 4,8 & hoog \\
BOL/BBL bouw & 4,7 & hoog
\end{tabular}


Tabel 4.4

Opleidingstypen met relatief de laagste uitbreidingsvraag in Limburg in 1999, in procenten van de werkgelegenheid

Opleidingstype

VBO landbouw en natuurlijke omgeving

Basisonderwijs

VBO administratie, handel en textiel

VBO motorvoertuigentechniek

VBO mechanische techniek

WO wiskunde en natuurwetenschappen

BOL/BBL geld, banken en belastingen

$\mathrm{HBO}$ lerarenopleiding talen
$\% \quad$ typering

\begin{tabular}{ll}
\hline$-3,5$ & erg laag \\
$-3,1$ & erg laag \\
$-2,6$ & erg laag \\
$-1,8$ & laag \\
$-1,7$ & laag \\
$-1,7$ & laag \\
$-1,0$ & laag \\
$-1,0$ & laag \\
\hline
\end{tabular}

Bron: $R O A$

Overigens laat een vergelijking van de ontwikkelingen naar beroepsgroep in de tabellen 4.1 en 4.2 met de ontwikkelingen naar opleidingstype een opmerkelijk verschil zien. De dynamiek in de werkgelegenheidsstructuur naar opleidingstype is veel groter dan naar beroepsgroep. Het upgradingproces heeft immers twee componenten. Enerzijds verschuift de arbeidsvraag steeds verder van de lagere naar de middelbare en hogere beroepen. Anderzijds worden binnen de beroepen de opleidingseisen steeds hoger. Als gevolg hiervan is de krimp in de vraag voor de lagere beroepen over het algemeen kleiner dan de werkgelegenheidskrimp voor de lagere opleidingen. Tevens is de groei in de vraag in de hogere beroepen kleiner dan de groei in de vraag naar hoger opgeleiden.

\section{Vervangingsvraag naar beroepsgroep ${ }^{28}$}

Tabel 4.5 geeft een illustratie van de beroepsgroepen waarvoor de vervangingsvraag in 1999 het grootst zal zijn. Twee zaken spelen hierbij een rol. De mobiliteit is zowel bij jongeren als bij ouderen hoog, zij het om verschillende redenen. Jongeren veranderen aan het begin van hun carriere regelmatig van baan (het zgn. job-hopping). Dit leidt overigens in een aantal gevallen niet tot extra vervangingsvraag omdat deze baan-baan-mobiliteit zich vaak binnen beroepsgroepen afspeelt en daardoor geen invloed heeft op de baanopeningen voor nieuwkomers in de betreffende beroepsgroep. Ouderen stromen daarentegen uit door pensionering, arbeidsongeschiktheid e.d. Verder treden vrouwen vaak tijdelijk van de arbeidsmarkt terug voor het uitvoeren van zorgtaken. De grootste vervangingsvraag zal dus naar verwachting optreden bij de beroepen waar deze groepen sterk vertegenwoordigd zijn. Daarnaast beinvloeden belastende arbeidsomstandigheden de omvang van de vervangingsvraag. Deze zal het hoogst zijn bij beroepen die als belastend worden ervaren. Bij de docenten talen en expressie is de vervangingsvraag vooral hoog vanwege de vergrijzing onder de leraren (31\% van de werkenden in deze beroepsgroep is ouder dan 50 jaar). Ook bij de

28 Voor meer uitgebreide informatie over o.a. de oorzaken van een hoge vervangingsvraag zij verwezen naar: Researchcentrum voor Onderwijs en Arbeidsmarkt, Determinants of Labour Outflow, 1999 (verschijnt binnenkort). 
beroepsgroepen managers en leidinggevenden speelt de vergrijzing een belangrijke rol (percentage ouderen 34 resp. 33\%). Bij de beroepsgroepen receptionisten en administratieve employés alsmede hulpkrachten horeca en verzorging is de hoge vervangingsvraag naar alle waarschijnlijkheid vooral toe te schrijven aan het feit dat hierin veel vrouwen werkzaam zijn $(75 \%$ resp. $79 \%)$.

Tabel 4.5

Beroepsgroepen met relatief de grootste vervangingsvraag in Limburg in 1999, in procenten van de werkgelegenheid

Beroepsgroep

$\% \quad$ typering

Docenten talen en expressie

Receptionisten en administratieve employés

5,9 erg hoog

Architecten en bouwkundig projectleiders

Confectie-arbeiders

Managers

Leidinggevenden

Hulpkrachten horeca en verzorging

Agrarische bedrijfshoofden

Bron: ROA

In tabel 4.6 staan de beroepen vermeld die voor 1999 een lage vervangingsbehoefte laten zien. De genoemde beroepen blijken behoorlijk divers naar niveau en richting te zijn. In veel van deze beroepen is de vervangingsvraag vooral beperkt vanwege de relatief lage leeftijd van de werkenden in deze functies. Veel jongeren veranderen weliswaar regelmatig van baan, zij blijven echter in dezelfde beroepsgroep werkzaam zodat de vervangingsvraag laag is.

\section{Tabel 4.6}

Beroepsgroepen met relatief de kleinste vervangingsvraag in Limburg in 1998, in procenten van de werkgelegenheid

\begin{tabular}{lll} 
Beroepsgraep & $\%$ & typering \\
\hline Programmeurs & 1,9 & erg laag \\
Activiteitenbegeleiders en medewerkers arbeidsbemiddeling & 2,4 & laag \\
Commercieel employés & 2,6 & laag \\
Organisatie-adviseurs & 2,6 & laag \\
Laders en lossers & 2,6 & laag \\
Verzorgend personeel & 2,7 & laag \\
Sociaal-cultureel werkers & 2,7 & laag \\
Systeemanalisten & 2,7 & laag
\end{tabular}




\section{Vervangingsvraag naar opleidingstype}

In de tabellen 4.7 en 4.8 worden de opleidingen gepresenteerd die respectievelijk de grootste en de kleinste vervangingsbehoefte kennen. In beide tabellen zijn opleidingen van verschillende niveaus en richtingen vertegenwoordigd. De grote vervangingsbehoefte bij de $H B O$ lerarenopleidingen talen en expressie weerspiegelt de hoge vervangingsvraag bij de docenten talen en expressie. Verder is er een duidelijk verband tussen de hoge vervangingsvraag bij de beroepsgroep receptionisten en administratieve employés (tabel 4.5 ) en de opleiding $H B O$ secretariaat (tabel 4.7). De HBO lerarenopleidingen talen en expressie, WO wiskunde en natuurwetenschappen en HBO werktuigbouwkunde behoorden ook in 1998 reeds tot de opleidingstypen met de hoogste vervangingsvraag. De hoge vervangingsvraag bij de opleiding $\mathrm{HBO}$ secretariaat heeft waarschijnlijk te maken met het feit dat het percentage vrouwen met deze opleidingsachtergrond maar liefst $97 \%$ bedraagt ${ }^{29}$. Bij VBO verzorging is dit percentage $94 \%$. Voor wat betreft de vervangingsvraag bij de opleidingstypen $H B O$ lerarenopleiding expressie en $H B O$ lerarenopleiding talen is een verband te leggen met het percentage ouderen; dit bedraagt 34 respectievelijk 29 procent.

Van de opleidingstypen in tabel 4.8 behoorden er drie ook vorig jaar tot de opleidingen met de laagste vervangingsvraag. Toen nam ook de opleiding VBO administratie, handel en textiel de eerste positie in en ook het opleidingstype HAVO/VWO liet een erg lage vervangingsvraagbehoefte zien. Algemeen gesteld gaat het in tabel 4.8 om opleidingen waarvoor de werkgelegenheid naar verwachting zal krimpen, waardoor de vervangingsbehoefte gering is.

Tabel 4.7

Opleidingstypen met relatief de grootste vervangingsvraag in Limburg in 1999, in procenten van de werkgelegenheid

\begin{tabular}{llll} 
Opleidingstype & $\%$ & typering \\
\cline { 4 - 4 } HBO secretariaat & & 5,1 & erg hoog \\
HBO lerarenopleiding expressie & 5,0 & erg hoog \\
WO wiskunde en natuurwetenschappen & 4,5 & hoog \\
HBO laboratorium & 4,4 & hoog \\
HBO werktuigbouwkunde & 4,4 & hoog \\
BOL openbare orde en veiligheid & 4,0 & gemiddeld \\
VBO verzorging & 3,9 & gemiddeld \\
HBO lerarenopleiding talen & 3,9 & gemiddeld \\
\hline
\end{tabular}

Bron: $\mathrm{ROA}$

29 De in deze paragraaf vermelde percentages vrouwen en ouderen per beroepsgroep en opleidingstype zijn gebaseerd op landelijke cijfers. Zij zijn ontleend aan: Researchcentrum voor Onderwijs en Arbeidsmarkt, De Arbeidsmarkt noar Opleiding en Berocp (Statistische Bijlage, Actualisering 1998), ROA-R-1998/9B. 
Tabel 4.8

Opleidingstypen met relatief de kleinste vervangingsvraag in Limburg in 1999, in procenten van de werkgelegenheid

Opleidingstype

$\% \quad$ typering

VBO administratie, handel en textiel

VBO landbouw en natuurlijke omgeving

HAVONWO

BOL/BBL automatisering

VBO horeca en levensmiddelentechniek

HBO informatica

BOL dokters-, tandarts- en dierenartsassistent

VBO elektrotechniek

\begin{tabular}{cl}
$\%$ & typering \\
\hline 1,3 & erg laag \\
1,4 & erg laag \\
1,9 & erg laag \\
2,0 & erg laag \\
2,0 & erg laag \\
2,1 & erg laag \\
2,3 & laag \\
2,3 & laag \\
\hline
\end{tabular}

Bron: ROA

Tabel 4.9

Beroepsgroepen met relatief het grootste aantal baanopeningen in Limburg in 1999, in procenten van de werkgelegenheid

\begin{tabular}{|c|c|c|c|c|}
\hline Beroepsgroep & $\%$ & typering & UV & VV \\
\hline Ziekenverzorgenden & 9,6 & erg hoog & erg hoog* & hoog \\
\hline Leidinggevenden & 8,7 & erg hoog & hoog & erg hoog* \\
\hline Architecten en bouwkundig projectleiders & 8,3 & erg hoog & hoog & erg hoog* \\
\hline Boekhouders en secretaresses & 8,0 & hoog & erg hoog* & gemiddeld \\
\hline Managers & 7,7 & hoog & hoog & erg hoog* \\
\hline Hulpkrachten horeca en verzorging & 7,7 & hoog & hoog & erg hoog* \\
\hline Confectie-arbeiders & 7,6 & hoog & gemiddeld & erg hoog* \\
\hline Systeemanalisten & 7,6 & hoog & erg hoog* & laag \\
\hline Apothekersassistenten en medisch laboranten & 7,3 & hoog & hoog* & $h_{0 o g}^{*}$ \\
\hline \multicolumn{5}{|l|}{ Activiteitenbegeleiders en medewerkers } \\
\hline arbeidsbemiddeling & 7,3 & hoog & erg hoog* & laag \\
\hline
\end{tabular}

* de belangrijkste oorzaak van het grote aantal baanopeningen

Bron: ROA

\section{Baanopeningen naar beroepsgroep}

De uitbreidings- en vervangingsvraag bepalen tezamen het aantal baanopeningen op de arbeidsmarkt. Tabel 4.9 illustreert voor welke tien beroepsgroepen het aantal baanopeningen in 1999 naar verwachting het grootst zal zijn. In sommige gevallen hangt dit samen met een grote uitbreidings-, in andere met een grote vervangingsvraag of met beide. Dit is in de tabel weergegeven in de kolommen UV en VV. Voor zes van de genoemde beroepsgroepen geldt dat zowel de uitbreidings- als de vervangingsvraag relatief (erg) hoog is. Bij twee beroepsgroepen hangt het grote aantal baanopeningen duidelijk samen met de hoge uitbrei- 
dingsvraag. De vervangingsvraag in deze beroepen is laag. Het gaat hier om de systeemanalisten en de activiteitenbegeleiders en medewerkers arbeidsbemiddeling. Verder zij opgemerkt dat voor slechts drie van de tien genoemde beroepsgroepen ook voor 1998 het hoogste aantal baanopeningen werd verwacht, te weten de managers, de ziekenverzorgenden en de hulpkrachten horeca en verzorging. Van de tien genoemde beroeps groepen liggen er acht op middelbaar niveau of hoger, terwijl van de beroepsgroepen waarvoor in 1998 het grootste aantal baanopeningen werd verwacht slechts de helft op dit niveau lag. Dit illustreert het reeds eerder gememoreerde upgradingproces op de arbeidsmarkt.

\section{Baanopeningen naar opleidingstype}

Tabel 4.10 biedt een overzicht van de opleidingstypen met relatief het grootste aantal baanopeningen. Voor acht van de tien genoemde opleidingstypen blijkt het grote aantal baanopeningen vooral samen te hangen met de hoge uitbreidingsvraagbehoefte. Dit is niet verrassend gezien de reeds eerder gememoreerde grote dynamiek in de opleidingenstructuur van de Limburgse werkgelegenheid. Bij de helft van deze opleidingen is de vervangingsvraag zelfs laag. Ten opzichte van de prognoses voor 1998 zijn er enkele veranderingen waar te nemen al werd ook toen de eerste plaats ingenomen door WO econom(-etr)ie. Nieuw zijn de opleidingstypen $H B O$ commerciële economie, $H B O$ secretariaat, $H B O$ bedrijfskunde en BOL/BBL vervoer.

Tabel 4.10

Opleidingstypen met relatief het grootste aantal baanopeningen in Limburg in 1999, in procenten van de werkgelegenheid

\begin{tabular}{|c|c|c|c|c|}
\hline Opleidingstype & $\%$ & typering & UV & VV \\
\hline WO econom(-etr)ie & 13,7 & erg hoog & erg hoog* & gemiddeld \\
\hline HBO commerciële economie & 9,3 & hoog & erg hoog* & laag \\
\hline BOL/BBL bouw & 8,4 & hoog & hoog $^{*}$ & gemiddeld \\
\hline HBO secretariaat & 8,3 & hoog & gemiddeld & erg hoog* \\
\hline HBO bedrijfskunde & 8,3 & hoog & hoog $^{*}$ & gemiddeld \\
\hline BOL/BBL procestechniek & 8,2 & hoog & hoog $^{*}$ & laag \\
\hline BOL/BBL vervoer & 8,1 & hoog & hoog $^{*}$ & gemiddeld \\
\hline BOL/BBL motorvoertuigentechniek & 8,0 & hoog & hoog* & laag \\
\hline BOL sociaal-cultureel & 7,8 & hoog & hoog $^{*}$ & laag \\
\hline HBO werktuigbouwkunde & 7,7 & hoog & gemiddeld & hoog ${ }^{*}$ \\
\hline
\end{tabular}

* de belangrijkste oorzaak van het grote aantal baanopeningen

Bron: ROA

\subsection{Instroom van schoolverlaters op de arbeidsmarkt}

Om de knelpunten op de Limburgse arbeidsmarkt in kaart te brengen, dienen de ontwikkelingen aan de vraagzijde van de arbeidsmarkt geconfronteerd te worden met de verwachte aanbodstromen. Hierbij is onder meer de verwachte arbeidsmarktinstroom van schoolverlaters van belang. Daarbij wordt alleen gekeken naar de opleidingen en beroepen op 
middelbaar niveau of lager, gezien het meer landelijke karakter van de arbeidsmarkt voor de hogere beroepen en opleidingen. Twee factoren zijn bij de instroom op de arbeidsmarkt van belang: het aantal leerlingen/studenten dat de betreffende opleiding heeft gekozen en de mate waarin de opleiding het eindpunt vormt van de (initiële) opleiding.

In tabel 4.11 wordt een overzicht gegeven van de beroepen met naar verwachting de grootste instroom van schoolverlaters in 1999. De economisch-administratieve beroepen zoals commercieel employés, boekhouders en secretaresses en de receptionisten en administratieve employés domineren de tabel. Dit illustreert de populariteit van deze beroepen bij de schoolverlaters. Opvallend is de grote instroom van programmeurs, hetgeen duidelijk maakt dat de ICT-branche een grote aantrekkingskracht op de schoolverlaters uitoefent. Het niet-reguliere onderwijs speelt bij de voorbereiding op dit beroep een belangrijke rol.

In tabel 4.12 is aangegeven voor welke opleidingstypen de instroom in 1999 relatief het grootst zal zijn. De grootste instroom (als percentage van de werkgelegenheid) is te verwachten bij mensen met een opleiding BOL/BBL beweging en therapie. Opvallend is de tweede plaats voor HAVO/VWO daar het hier geen beroepsopleiding betreft. Het geringe aantal werkenden met deze opleidingsachtergrond - als gevolg van het feit dat veel HAVOen VWO-gediplomeerden doorstromen naar een vervolgopleiding - speelt hierbij een belangrijke rol. Meer voor de hand liggend zijn de overige genoemde opleidingstypen waar wel een verband met één of meer specifieke beroepen bestaat. Een vergelijking met de prognoses voor 1998 laat zien dat het patroon van de arbeidsmarktinstroom van schoolverlaters redelijk stabiel is.

Tabel 4.11

Beroepsgroepen met relatief de grootste arbeidsmarktinstroom van schoolverlaters in Limburg in 1999, in procenten van de werkgelegenheid

\begin{tabular}{lll} 
Beroepsgroep & $\%$ & typering \\
\hline Programmeurs & 4,2 & hoog \\
Productieplanners & 3,8 & gemiddeld \\
Bedrijfshoofden horeca & 3,7 & gemiddeld \\
Commercieel employés & 3,3 & gemiddeld \\
Winkeliers & 3,3 & gemiddeld \\
Boekhouders en secretaresses & 3,2 & gemiddeld \\
Receptionisten en administratieve employés & 3,1 & gemiddeld \\
Laders en lossers & 2,8 & gemiddeld \\
\hline
\end{tabular}

Bron: ROA 
Tabel 4.12

Opleidingstypen met relatief de grootste arbeidsmarktinstroom van schoolverlaters in Limburg in 1999, in procenten van de werkgelegenheid

Opleidingstype

$\%$

\begin{aligned}$\% &$ typering \\ \hline 14,0 & erg hoog \\ 7,6 & erg hoog \\ 5,5 & hoog \\ 4,7 & hoog \\ 4,7 & hoog \\ 4,6 & hoog \\ 4,3 & hoog \\ 3,8 & gemiddeld \end{aligned}

BOL/BBL beweging en therapie

HAVONWO

BOL sociaal-cultureel

VBO administratie, handel en textiel

Basisonderwijs

VBO motorvoertuigentechniek

BOL/BBL secretariaat

VBO horeca en levensmiddelentechniek

Bron: ROA

\subsection{Knelpunten in de personeelsvoorziening en arbeidsmarktperspectief in 1999 naar opleiding en beroep}

De cijfers over arbeidsvraag en -aanbod zoals die in de vorige twee paragrafen zijn gepresenteerd, vormen de basis voor het vaststellen van knelpunten die werkgevers zullen ondervinden in de personeelsvoorziening en van de arbeidsmarktperspec tieven voor nieuwkomers op de arbeidsmarkt. Hiervoor is gebruik gemaakt van twee indicatoren, de ITKB en de ITA ${ }^{30}$.

\section{Knelpunten naar beroepsgroep}

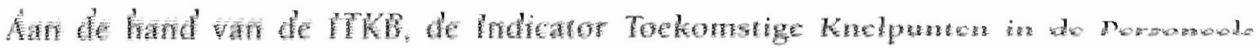

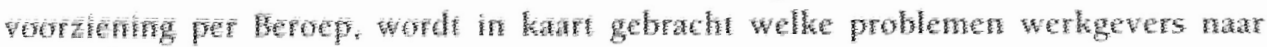
verwahtng zullen ondephnder bij het winden van geschiht personeel. Naamate de

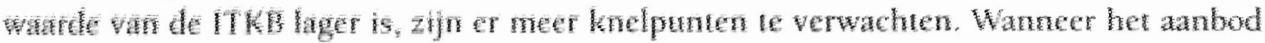
Mene is dan de vatag en de TKB klener is dan 1,00 , dan worden de knelpunten in de

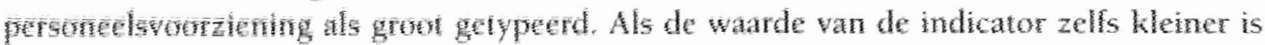
dan 0,85 tan worli gespriken van zeer grote knelpunen. Wameer de ITKB daarentegen gevtet is dan 1.00, mat detner dan 1,05 word gesproken van enige knepunten. Bij een hogere warde van de $1 \mathrm{TH}$ wordi gesproken van vrijwel geen knelpunten, en als de ITKB zelfs groter is twn 1,45 van geen knelpunten in de personeelsvoorziening.

Wf Iit dit rappot is etonr gekgzen bij de bervepgrospen ale nadruk te leggen op de knelpunten in de personectseotzlening. Werlgevers zign immers primair op zoek naar nieuwe arbeidskrachten die bepaalde taket binten het bedrif of de instelling kunnen verrichten. Bij de opleidingen ligt de nadruk op het

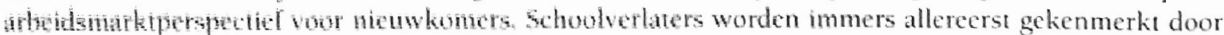
hut betwryen kwalficaties. De opleidingsachergrond vorm hiervoor een goede gradmeter. Zie voor de beflpumen that opleidingstype an de perspectieven nat beroepsgrocp de Statistische Bijlage 
Tabel 4.13 geeft een overzicht van de beroepsgroepen waarvoor de knelpunten in de personeelsvoorziening naar verwachting in 1999 in Limburg relatief gering zullen zijn. De tabel laat zien dat in de beroepsgroep productiemedewerkers vrijwel geen knelpunten worden verwacht. Het feit dat de instroom duidelijk achterblijft bij het aantal baanopeningen impliceert dat er voldoende werkzoekenden in fase 1 beschikbaar zullen zijn om aan de vraag te voldoen. Ook voor de drie andere beroepsgroepen zorgt de beschikbaarheid van voldoende werkzoekenden ervoor dat werkgevers relatief weinig problemen zullen ondervinden om geschikt personeel te vinden. Ook voor een aantal relatief kleine beroepsgroepen zoals de agrarische vakkrachten, de schippers en conducteurs en de verpleeghulpen en leerlingverpleegkundigen worden (vrijwel) geen knelpunten in de personeelsvoorziening verwacht in 1999 .

Tabel 4.13

Beroepsgroepen met relatief de kleinste knelpunten in Limburg in 1999

Beroepsgroep

Productiemedewerkers

Commercieel employés

Hulpkrachten horeca en verzorging

Bedrijfshoofden horeca
ITKB

\begin{tabular}{ll}
\hline 1,05 & vrijwel geen \\
1,01 & enige \\
1,01 & enige \\
1,01 & enige \\
\hline
\end{tabular}

Bron: $R O A$

In tabel 4.14 wordt een overzicht gegeven van de beroepsgroepen waarvoor de grootste knelpunten in de personeelsvoorziening worden verwacht. De tabel illustreert dat over de volle breedte van de Limburgse arbeidsmarkt knelpunten in de personeelsvoorziening zullen optreden. In de tabel staat aangegeven waardoor deze knelpunten voornamelijk worden veroorzaakt, dus in hoeverre er ontwikkelingen aan de vraag- dan wel aan de aanbodzijde aan de knelpunten ten grondslag liggen. Daartoe zijn de kolommen baanopeningen (de resultante van uitbreidings- en vervangingsvraag) en arbeidsmarktinstroom toegevoegd. De grootste knelpunten worden verwacht bij de productieplanners. Hoewel de verwachte instroom in 1999 relatief groot is, schiet deze tekort om aan de vraag te voldoen. De relatief grote stromen aan zowel de vraag- als aan de aanbodzijde van de markt voor productieplanners geven aan dat deze beroepsgroep naar verwachting snel aan belang zal winnen op de Limburgse arbeidsmarkt. De tabel laat verder zien dat op brede schaal knelpunten in de personeelsvoorziening worden verwacht. De diversiteit aan beroepen in de tabel is immers groot. 
Tabel 4.14

Beroepsgroepen met relatief de grootste knelpunten in Limburg in 1999

Beroepsgroep

Productieplanners

Ziekenverzorgenden

Confectie-arbeiders

Apothekersassistenten en medisch laboranten

Elektromonteurs

Agrarische arbeiders

Juridisch en fiscaal medewerkers

Chauffeurs
ITKB typering baanopeningen instroom

\begin{tabular}{llll}
\hline 0,91 & groot & erg hoog & gemiddeld \\
0,93 & groot & erg hoog & laag \\
0,94 & groot & hoog & laag \\
0,95 & groot & hoog & laag \\
0,96 & groot & hoog & gemiddeld \\
0,96 & groot & hoog & laag \\
0,97 & groot & gemiddeld & laag \\
0,97 & groot & hoog & laag \\
\hline
\end{tabular}

Bron: ROA

\section{Arbeidsmarktperspectieven naar opleidingstype}

De arbeidsmarktperspectieven voor de verschillende opleidingstypen worden in kaart gebracht met behulp van de Indicator Toekomstige Arbeidsmarktperspectieven (ITA) die aangeeft welke vraag-aanbod-discrepantie er per opleidingstype te verwachten is. Zoals reeds werd vermeld, impliceert een aanbodoverschot echter niet vanzelfsprekend dat de desbetreffende groep werkloos zal worden, terwijl een aanbodtekort niet automatisch betekent dat er sprake zal zijn van onvervulde vacatures. Wanneer de ITA kleiner is dan 1,00 zijn de perspectieven goed te noemen, wanneer deze zelfs kleiner is dan 0,85 zijn ze zeer goed. Een ITA groter dan of gelijk aan 1,00 maar kleiner dan 1,05 duidt op redelijke perspectieven. Bij een ITA groter dan of gelijk aan 1,05 zijn de perspectieven matig, en bij een ITA die groter is dan 1,15 zijn deze slecht.

Een vergelijking van de prognoses voor 1999 en de vorig jaar gemaakte prognoses voor 1998 laat duidelijk zien dat de verkrapping op de Limburgse arbeidsmarkt steeds verder toeneemt en zich bovendien op steeds meer segmenten van de arbeidsmarkt manifesteert. Voor 1998 werd voor 30 van de 52 opleidingstypen een goed tot zeer goed perspectief verwacht. Voor 1999 zal dit aantal naar verwachting stijgen tot maar liefst 33 opleidingstypen. Op MBO-niveau komt de verkrapping nog veel sterker tot uiting. Werd voor 1998 voor 26 van 35 opleidingstypen een (zeer) goed perspectief verwacht; voor 1999 zal voor de nieuwkomers op de arbeidsmarkt van 29 opleidingstypen het perspectief goed tot zeer goed zijn.

Tabel 4.15 geeft een overzicht van de opleidingstypen waarvoor de beste perspectieven op de Limburgse arbeidsmarki verwacht worden. De kolommen baanopeningen en instroom geven een indicatie van de voornaamste oorzaak van de goede perspectieven. De beste perspectieven zijn te vinden bij de technische opleidingen. Dit heeft zowel te maken met een groot aantal baanopeningen als met een lage instroom, met uitzondering van de opleiding BOLBBL motorvoertuigentechnick waar de instroom hoger is dan bij de andere twee technische opleidingen. Voor de overige genoemde opleidingstypen geldt eveneens dat de 
goede perspectieven samenhangen met zowel een groot aantal baanopeningen als met een lage instroom, al is dit minder uitgesproken het geval dan bij de technische opleidingen.

Tabel 4.15

Opleidingstypen met goede arbeidsmarktperspectieven in Limburg in 1999

Opleidingstype

BOL/BBL procestechniek

BOL/BBL motorvoertuigentechniek

BOL/BBL installatietechniek

$B O L$ openbare orde en veiligheid

BOL/BBL bedrijfskunde

$B O L / B B L$ verpleging

BOL dokters-, tandarts- en dierenartsassistent

BOL/BBL vervoer
ITA typering baanopeningen instroom

\begin{tabular}{llll}
\hline 0,93 & goed & hoog & laag \\
0,94 & goed & hoog & hoog \\
0,94 & goed & gemiddeld & erg laag \\
0,95 & goed & gemiddeld & erg laag \\
0,95 & goed & gemiddeld & erg laag \\
0,95 & goed & gemiddeld & laag \\
0,95 & goed & gemiddeld & erg laag \\
0,95 & goed & hoog & laag
\end{tabular}

Bron: $R O A$

Ondanks de krapte die arbeidsmarktbreed wordt ervaren, zijn er opleidingstypen waarvoor de perspectieven minder goed zijn. Tabel 4.16 geeft een overzicht van de opleidingstypen met een matig of redelijk arbeidsmarktperspectief. De opleiding BOL/BBL beweging en therapie is het minst perspectiefrijk. Hier ligt met name de omvangrijke arbeidsmarktinstroom van schoolverlaters aan ten grondslag. De andere opleidingstypen kunnen in twee groepen opgesplitst worden: in de eerste plaats de VBO-opleidingen en in de tweede plaats de algemene opleidingen MAVO en HAVO/VWO. Dat sluit aan bij het beeld dat vorig jaar voor 1998 werd geschetst. Aan het redelijke tot matige perspectief voor verschillende VBOopleidingen ligt met name het geringe aantal baanopeningen ten grondslag. Als gevolg van de upgrading van de opleidingseisen wordt er, met uitzondering van VBO bouwtechniek, een krimp in de werkgelegenheid verwacht voor deze opleidingen. Daarnaast zijn er op VBOniveau over het algemeen nog relatief veel direct bemiddelbare werkzoekenden beschikbaar. De oorzaken van het mindere perspectief van de opleidingen MAVO en HAVO/VWO zijn vooral aan de aanbodzijde te vinden. Er zijn voldoende direct inzetbare werkzoekenden beschikbaar. Daarnaast is de instroom van schoolverlaters naar verwachting relatiel groot. 
Tabel 4.17

Opleidingstypen met matige of redelijke arbeidsmarktperspectieven in Limburg in 1999

Opleidingstype

BOL/BBL beweging en therapie

VBO administratie, handel en textiel

VBO bouwtechniek

HAVO/NWO

VBO verzorging

MAVO

VBO motorvoertuigentechniek

VBO horeca en levensmiddelentechniek

Basisonderwijs
ITA typering baan- instroom openingen

\begin{tabular}{llll}
1,11 & matig & gemiddeld & erg hoog \\
1,08 & matig & erg laag & hoog \\
1,05 & redelijk & laag & gemiddeld \\
1,05 & redelijk & gemiddeld & erg hoog \\
1,03 & redelijk & laag & gemiddeld \\
1,02 & redelijk & gemiddeld & gemiddeld \\
1,02 & redelijk & laag & hoog \\
1,02 & redelijk & erg laag & gemiddeld \\
1,02 & redelijk & laag & hoog \\
\hline
\end{tabular}

Bron: $R O A$ 


\section{Knelpunten in perspectief}

\subsection{Inleiding}

De voorgaande hoofdstukken van dit rapport hebben laten zien dat de Limburgse arbeidsmarkt in toenemende mate gekenmerkt wordt door een tekort aan geschikt personeel. Er zijn te weinig direct inzetbare arbeidskrachten beschikbaar om aan de uitbreidings- en vervangingsbehoefte te voldoen. In dit hoofdstuk worden de verwachte knelpunten in een nader perspectief geplaatst. In paragraaf 5.2 wordt ingegaan op de achtergronden van de tekorten aan geschikt personeel in de drie sectoren die dit jaar in het RAIL-project nader onder de loep zijn gehouden: de bouw, de zakelijke dienstverlening en de zorg. Inzicht in de oorzaken van de knelpunten in de personeelsvoorziening kan het startpunt vormen voor het vinden van mogelijke oplossingen van het probleem. Ook deze mogelijke oplossingen komen in paragraaf 5.2 aan de orde. In paragraaf 5.3 wordt één specifieke oplossingsrichting nader belicht om via het bevorderen van de arbeidsmarktparticipatie de knelpunten op de Limburgse arbeidsmarkt te verminderen. Dit hoofdstuk wordt in paragraaf 5.4 afgesloten met een aantal afsluitende conclusies in de vorm van een aantal aandachtspunten voor het participatiebeleid.

\subsection{Knelpunten op de Limburgse arbeidsmarkt: oorzaken en oplossingen}

In de voorafgaande hoofdstukken zijn de tekorten aan direct inzetbaar personeel in kaart gebracht. Aan de vraagzijde van de arbeidsmarkt liggen de gunstige werkgelegenheidsontwikkeling en de toenemende vervangingsbehoefte aan deze knelpunten ten grondslag. Aan de aanbodzijde van de arbeidsmarkt eisen de verdergaande ontgroening en vergrijzing van de beroepsbevolking hun tol. Met name hoofdstuk 3 heeft echter laten zien dat er in principe voldoende werkzoekenden beschikbaar zijn op de Limburgse arbeidsmarkt. De afstand van deze werkzoekenden tot de arbeidsmarkt blijkt echter vaak relatief groot te zijn. Dit impliceert dat de aansluitingsproblematiek op de Limburgse arbeidsmarkt voor een belangrijk deel kwalitatief van aard is. In deze paragraaf zal dit algemene beeld nader ingevuld worden voor de drie sectoren bouw, zakelijke dienstverlening en zorg.

\section{De aansluitingsproblematiek in de bouw}

De bouwsector kent in vergelijking met het algemene beeld geen uitzonderlijk grote wervingsproblemen. De belangrijkste knelpunten in de personeelvoorziening doen zich voor bij de bouwinstallatiebedrijven. Naar beroepsgroep blijken de belangrijkste knelpunten zich voor te doen bij de (assistent) straatmakers, de steigerbouwers, de schilders, de allround vaklieden burger- en utiliteitsbouw en grond-, weg-en waterbouw, de assistenten installatietechniek, de verwarmingsmonteurs, de installatiemonteurs, de dakbedekkingsmonteurs, de aankomend projectlechnici gebouwen en installaties, de calculatoren burgeren utiliteitsbouw en bouwinstallatie, de werkvoorbereiders burger- en utiliteitsbouw en bouwinstallatie, het grond-, weg- en waterbouw-middenkader en het hoger kader (o.a. vestigingsleiders). 
Uit dit overzicht naar beroep blijkt dat bij de bouwinstallatiebedrijven de knelpunten vooral liggen op het uitvoerend niveau, namelijk bij de diverse monteurs. Voor de burgeren utiliteitsbouw geldt dat in de uitvoerende sfeer de ervaringen nogal wisselend zijn. Wel is er een duidelijke behoefte aan breed inzetbare vakkrachten. De grond-, weg- en waterbouwbedrijven hebben ook behoefte aan breed inzetbare vakkrachten. Daarnaast gaat het bij deze bedrijfsgroep ook om een enkele uitvoerende functie. De grond-, weg- en waterbouwbedrijven hebben te kampen met een seizoensgebondenheid van de vacatures. Er wordt gesignaleerd dat in de winter vacatures doorgaans makkelijker te vervullen zijn.

Moeilijk vervulbare vacatures komen op alle opleidingsniveaus voor. De aanvullende eisen die gesteld worden, zijn beperkt. Vakmanschap staat voorop; bij functies waarin men direct contact heeft met klanten wordt dit aangevuld met klantvriendelijkheid en bij meer leidinggevende functies met sociaal-communicatieve vaardigheden en overtuigingskracht. Bij de leidinggevende functies speelt ook ervaring een belangrijke rol. De straatmakers, steigerbouwers en schilders zijn functies op geoefend en lager niveau. Door middel van een schakeltraject kan in principe iedereen voor deze functies worden opgeleid. Voor de vacatures voor breed inzetbare vaklieden is, afhankelijk van de vereiste geoefendheid en inzetbaarheid, kwalificatieniveau 2 of 3 vereist. Daarnaast speelt in de grond-, weg- en waterbouwsector lichamelijke geschiktheid een rol. De monteurs dienen kwalificatieniveau 3 te hebben. Ook dienen de monteurs klantgericht te zijn en zelfstandig te kunnen handelen. De functies van calculator, werkvoorbereider en functies in het grond-, weg- en waterbouwmiddenkader en het hoger kader vereisen minimaal kwalificatieniveau 4 of een HBO-opleiding. Opvallend is dat de bouwintallatiebedrijven hogere opleidingseisen stellen aan personeel in de werkvoorbereiding dan de burger- en utiliteitsbouw. In de hogere functies zijn vooral leidinggevende capaciteiten belangrijk; in sommige gevallen kunnen deze het gebrek aan technische kennis compenseren.

In algemene zin zijn er twee belangrijke oorzaken aan te wijzen voor de moeilijk vervulbare vacatures in de bouw:

- de ontgroening en dalende populariteit van technische opleidingen. Dit probleem doet zich in Limburg sterker voor dan landelijk;

- het slechte imago van het werk in de bouw in het algemeen en het uitvoeringswerk in het bijzonder als gevolg van seizoenswerk, werken op projectbasis en zware arbeidsomstandigheden. Dit beeld is vooral van toepassing op het werk in de grond-, weg-en waterbouwbedrijven. Voor de bouwinstallatiebedrijven geldt tevens dat het beroep installateur relatief onbekend is.

Andere factoren die een rol spelen zijn: de sterke vergrijzing, de sterke concurrentie tussen bedrijven op de arbeidsmarkı en het specialistische karakter van de monteursopleidingen.

Verwacht wordt dat de knelpunten in de personeelvoorziening in de bouw ook in de (nabije) toekomst zullen optreden. Gezien de belangrijkste oorzaken van deze knelpunten: de ontgroening en vergrijzing van de beroepsbevolking, de geringe populariteit van de technische opleidingen en het slechte imago van het werk in de bouw, speelt de verwachte economische ontwikkeling hierbij een ondergeschikte rol. Ook wanneer de conjuncturele ontwikkeling ongunstig zou uitvallen, zullen de bouwbedrijven naar verwachting met knelpunten geconfronteerd worden. De tekorten zullen naar verwachting voor een belangrijk deel kwalitatief van aard zijn: er is een tekort aan gekwalificeerd personeel (niveau 3) en 
een overschot aan lager geschoolden (niveau 1 en 2). Twee aspecten verdienen extra aandacht. In de eerste plaats wijst de bouwsector zelf specifiek op de schildersbranche waar grote problemen verwacht worden. In de tweede plaats wijst het onderwijs op de verwachte problemen in de personeelsvoorziening voor bouwdocenten.

Vakmanschap staat ook in de toekomstige kwalificatie-eisen centraal. De eis dat men een gedegen opleiding, beroepsopleidend of -begeleidend, heeft gevolgd, staat voorop. Daarnaast zullen aanvullende eisen steeds belangrijker worden. Houding en klantvriendelijkheid worden voor meer en meer functies in de bouw van belang. Daarnaast wordt steeds meer de nadruk gelegd op de bereidheid tot verdere scholing.

Direct inzetbaar personeel, met name schoolverlaters, wordt in de bouwsector steeds schaarser. Dit betekent dat alternatieve wervingscategorieën steeds meer in beeld komen. De ervaringen in de bouwsector met het inzetten van dergelijke arbeidskrachten zijn veelal positief. Voortijdig schoolverlaters en werklozen kunnen veelal na het volgen van (eventueel) een voortraject en een vakopleiding aan de slag. De ervaringen met herintredende vrouwen zijn wisselend. Positief zijn de sociale vaardigheden. De negatieve geluiden komen daarbij veelal uit de grond-, weg- en waterbouw en de bouwintallatiebedrijven. Het aantrekken van Belgen en Duitsers wordt op de korte termijn als een alternatief gezien, maar biedt op de wat langere termijn geen continuiteit. Met het overig buitenlands personeel zijn de ervaringen wisselend. Het werven van personeel bij andere bedrijven biedt weinig soelaas. Het werven van personeel dat reeds elders in de bouw werkzaam is verplaatst het probleem slechts van het ene bedrijf naar andere bedrijven. Het aantrekken van personeel buiten de bouw ten slotte wordt door de bouwsector te duur gevonden.

Het individuele bouwbedrijf kan, naast het werven van alternatieve categorieën, de knelpunten op verschillende manieren verminderen. Er kan gedacht worden aan aanpassingen binnen de organisatie zoals functiesplitsing, job-rotation, verdergaande professionalisering en het vergroten van de mogelijkheden om in deeltijd te werken. Scholing vormt een tweede oplossingsrichting. Scholing van het personeel bevordert ook de doorstroom naar hogere functies en het vergroot daarmee de carrièremogelijkheden. Enerzijds wordt hiermee het werken in de sector aantrekkelijker. Anderzijds wordt hiermee de behoefte aan nieuw personeel verplaatst naar de lagere functies waar de krapte op de arbeidsmarkı geringer is.

Gezamenlijk kunnen de bedrijven in de bouw trachten het imago van het werk in de sector te verbeteren. Ook kunnen banenpools mogelijk de wervingskracht van de bouwsector vergroten, wanneer op deze wijze vaste contracten kunnen worden aangeboden. Voor deze samenwerking is netwerking en het bevorderen van persoonlijke contacten een belangrijke voorwaarde. Tenslotte is het vergroten van het aantal beroepspraktijk-vormingsplaatsen van groot belang

Ook in de samenwerking van de bouwsector met het onderwijs kan het bevorderen van het imago van de bouw en de bouwopleidingen op termijn de belangstelling voor de bouwsector vergroten. Het vergroten van de aantrekkelijkheid van het onderwijs speelt hierbij een centrale rol. Het gaat hierbij niet alleen om de inhoud van de opleiding, maar bijvoorbeeld ook om het bieden van een opleiding in de regio en het aanbieden van avondopleidingen 
in deeltijd. Samenwerking tussen het onderwijs en de bouwsector dient met name op regionaal niveau bevorderd te worden. Een laatste factor is het vergroten van het rendement van de opleidingen. Hierbij gaat het zowel om het verhogen van de slagingspercentages, als om de doorstroom naar vervolgopleidingen (met name van niveau 2 naar niveau 3 ).

\section{De aansluitingsproblematiek in de zakelijke dienstverlening ${ }^{31}$}

De zakelijke dienstverlening wordt in Limburg geconfronteerd met een krappe arbeidsmarkt. Zowel de verhouding tussen vacatures en werkzoekenden als het percentage langdurig openstaande vacatures is in deze sector relatief hoog. In vergelijking met de Randstad zijn de wervingsproblemen in Limburg echter nog relatief gering. De belangrijkste knelpunten in de personeelsvoorziening blijken zich in Limburg voor te doen bij de beveiligingsbeambten, de telefonistes en secretaresses, de commerciēle functies in de buitendienst (in het bijzonder assurantiemedewerkers), de medewerkers call-centers en telemarketing, de accountants, de informatici (zowel soft- als hard-ware), de management-consultants en de leidinggevenden (zowel algemeen als specifiek: ICT, financieel-economisch).

Dit overzicht naar beroep geeft een divers beeld te zien. In algemene zin kan geconcludeerd worden dat de beveiligingsbranche de minste problemen kent en de ICT-sector de grootste. Eigenlijk bestaan er voor alle relevante beroepsgroepen in de ICT-sector wervingsproblemen. De financieel-administratieve branche, dat wil zeggen, het bank- en verzekeringswezen en de accountancybranche, heeft ook vele moeilijk vervulbare vacatures. De nadruk ligt hierbij op de hogere functies. Het zogenaamde back-office werk kent ook nog een aantal makkelijk vervulbare vacatures. Het gaat hier met name om uitvoerende functies.

In de zakelijke dienstverlening komen moeilijk vervulbare vacatures op alle opleidingsniveaus voor. Voor de functie van beveiligingsbeambte is een lagere opleiding vereist. Een aantal functies vereist een middelbare beroepsopleiding. De meeste moeilijk vervulbare vacatures in de zakelijke dienstverlening bevinden zich echter op $\mathrm{HBO}$ - en academisch niveau. Een specifieke opleidingsrichting is in sommige gevallen van secundair belang. Gezien de ontwikkelingen binnen de vakgebieden wordt het wel belangrijk gevonden dat personeel 'up-to-date' opgeleid is. De bereidheid van werknemers om opleidingen te blijven volgen en in zichzelf te blijven investeren, is dan ook erg belangrijk. De vakspecifieke kennis moet bovendien gecombineerd worden met sociaal-communicatieve vaardigheden. Deze vaardigheden kunnen het gebrek aan specifieke kennis compenseren. Ook ervaring kan een gebrek aan specifieke kennis compenseren. Zo blijkt een MBO'er met ervaring voor een werkgever vaak even aantrekkelijk of zelfs aantrekkelijker dan een net afgestudeerde HBO'er. Met name voor leidinggevende functies spelen niet-vakinhoudelijke aspecten een belangrijke rol.

In algemene zin zijn er zowel aan de vraag-als aan de aanbodzijde van de arbeidsmarkt factoren aan te wijzen die een rol spelen bij de personeelsschaarste. Aan de aanbodzijde van

31 De zakelijke dienstverlening is een sector met een breed scala aan activiteiten. In het kader van RAIL zijn de volgende sectoren binnen de zakelijke dienstverlening nader belicht: het bank- en verzekeringswezen, de accountancy en administratie, de informatie- en communicatietechnologie (ICT) sector en de beveiliging. 
de arbeidsmarkt is er sprake van een beperkte nieuwe instroom. Daarnaast zijn er te weinig ervaren krachten beschikbaar. Aan de vraagzijde levert het dynamisch karakter van de sector voor veel bedrijven problemen op. Een deel van de sector bestaat uit jonge bedrijuen. Daarnaast gaat het om een dynamische, snel groeiende sector. De uitbreidingsvraag is daarom groot. Het gaat hierbij vaak om nieuwe functies. Daarnaast is er sprake van snelle technologische ontwikkelingen. Kennis veroudert daardoor snel, waardoor er continu vraag is naar gekwalificeerd personeel. De concurrentie tussen de bedrijven op de arbeidsmarkt is daarom groot. Met name kleine bedrijven (arbeidsvoorwaarden, minder carrièreperspectief, minder opleidingsmogelijkheden) zijn hierbij in het nadeel. Tenslotte kan bij de leidinggevende functies de perifere ligging van Limburg een rol spelen. Zeker bij een plaatsing vanuit een hoofdkantoor levert dit nogal cens een knelpunt op.

Op de korte termijn worden over de gehele linie in de zakelijke dienstverlening knelpunten in de personeelsvoorziening verwacht. Hierbij draagt de verwachte gunstige werkgelegenheidsontwikkeling in belangrijke mate bij aan het verwachte tekort aan geschikt personeel. In specifieke functies - receptionisten, leidinggevenden en verzekeringsagenten - is er daarnaast sprake van een grote vervangingsbehoefte. De nieuwe instroom is voor de meeste beroepen naar verwachting gering. Op de wat langere termijn worden met name op middelbaar en hoger niveau op steeds bredere schaal problemen verwacht. Bovendien ontstaan binnen de zakelijke dienstverlening steeds nieuwe functies, met name doordat in bepaalde functies verschillende vakgebieden in functies moeten worden gecombineerd. Het gaat hier vooral om combinaties tussen ICT-, financieel-economische en commerciële vaardigheden. Daarnaast worden adviesvaardigheden, gecombineerd met sociaal-communicatieve vaardigheden, steeds belangrijker. Tenslotte wordt steeds meer de nadruk gelegd op flexibiliteit en een brede inzetbaarheid. Dit resulteert per saldo in een verhoging van het voor het werk vereiste opleidingsniveau (met uitzondering van de beveiligingsbranche).

Direct inzetbaar personeel, met name schoolverlaters, wordt dus steeds schaarser. Voor sommige schoolverlaters blijkt alleen een gebrek aan sociaal-communicatieve vaardigheden een belemmering te zijn voor het vinden van een baan. Middelbaar opgeleiden lijken in bepaalde gevallen zelfs een streepje voor te hebben op hoger opgeleiden, gezien hun grotere praktijkervaring.

Het tekort aan direct inzetbaar personeel betekent dat alternatieve wervingscategorieèn steeds meer in beeld komen. Met bepaalde categorieèn is al ervaring opgedaan. Vooral werklozen zijn (voor de ICT-sector) een belangrijke wervingscategorie. Omscholing is hierbij van groot belang. Het gaat hierbij echter niet om een structurele oplossing van de knelpunten. Bovendien kan het ontbreken van een structurele relatie met het onderwijs de ontwikkeling van scholingsprogramma's belemmeren. Aansluitingsproblemen worden in de zakelijke dienstverlening vooral als opleidings- en begeleidingsproblemen geinterpreteerd. Middels de opleiding moeten de vakspecifieke kennis en communicatieve vaardigheden op peil gebracht worden en middels de begeleiding moet de inbedding in de bedrijfscultuur plaatsvinden.

Gedurende een reeks van jaren worden werkzoekenden omgeschoold om de knelpunten op de arbeidsmarkt voor de bedrijven in de zakelijke dienstverlening te verminderen. De sector beseft dat dit slechts een tijdelijke oplossing is. Het is beter om te investeren in een struc- 
turele relatie met het onderwijs. Hierbij kan onder meer gedacht worden aan het bevorderen van het duaal leren, het opzetten van een commissie onderwijs-bedrijfsleven, het bevorderen van stages, het starten van een eigen academie ICT en het direct benaderen van bijna afgestudeerden.

Andere oplossingsrichtingen worden gezocht in het (verder) professionaliseren van het personeels- en opleidingsbeleid. Ad hoc beleid moet strategisch beleid worden. Daarbij staat behoud en doorstroom van het eigen personeel voorop (bijvoorbeeld vrouwen en ervaren krachten). Verder wordt onderkend dat bedrijfsculturen heel verschillend zijn. Bedrijven zouden dan ook meer moeten samenwerken op het gebied van personeel. Een eerste stap vormen mobiliteitsplannen. Verder is het van belang te komen tot structurele personeelsuitwisselingen, teneinde de juiste man op de juiste plaats te krijgen. Als voorbeelden zijn aangedragen: uitwisselingen tussen ICT-bedrijven en de (semi-)overheid en tussen accountancy en bankwezen.

\section{De aansluitingsproblematiek in de zorg}

In algemene zin blijkt de arbeidsmarkt in de kwartaire sector (waaronder de zorg valt) wat minder gespannen in vergelijking met het gemiddelde beeld op de Limburgse arbeidsmarkt. Het aantal moeilijk vervulbare vacatures neemt echter wel toe. Limburg komt hierbij wat gunstiger uit de bus dan bijvoorbeeld de Randstad. Dat de Limburgse zorgsector in het voordeel is wordt toegeschreven aan de geografische ligging met de mogelijkheid met name Belgische verpleegkundigen te werven en aan de gebondenheid van de Limburgers aan de eigen geboortestreek. De belangrijkste knelpunten in de personeelsvoorziening in de zorgsector doen zich voor bij de kraamverzorgenden en de verzorgenden individuele gezondheidszorg, de intensive-care- en kinderverpleegkundigen, de apothekersassistenten, de röntgen- en diagnostisch laboranten en de automatiseerders. Daarnaast is er een tekort aan flex-krachten en vervangers op alle niveaus.

Dit overzicht naar beroep laat zien dat er weliswaar probleemberoepen bestaan in de zorg, maar dat het vooral gaat om functies waarin specifieke kwalificaties worden gevraagd. Naast vakinhoudelijk specialistische kennis spelen in de zorg het goed kunnen omgaan met kwetsbare mensen (alle beroepen), sociaal-communicatieve vaardigheden, patiëntgerichtheid, levenservaring, teamgeest, stabiliteit en zelfstandigheid een belangrijke rol.

Er zijn een aantal factoren die ten grondslag liggen aan het moeilijk vervulbaar zijn van vacatures in de zorg in Limburg. De ontgroening eist ook in de zorg zijn tol; steeds minder jongeren volgen een zorgopleiding. Een bijkomend probleem vormt de beperkte beschikbaarheid van opleidingsplaatsen. Daarnaast is de motivatie voor de keuze van een zorgberoep veranderd. Tegenwoordig wordt vaak een rationele afweging gemaakt, waarbij arbeidsvoorwaarden en -omstandigheden een veel grotere rol spelen dan vroeger. Naast deze aanbodfactoren zijn er ook duidelijke factoren aan te wijzen die verband houden met de sector zelf. Ten eerste speelt het imago van het werk in de zorgsector een belangrijke rol. Sleutelwoorden voor dit imago zijn: vooral flexibele arbeidscontracten, onregelmatig werk, fysiek en psychisch zwaar werk, slechte salariëring, hoge werkdruk, steeds nieuwe regelgevingen en bezuinigingen. De thuiszorg daarentegen word steeds meer geassocieerd met huishoudelijk werk. Ten tweede gelden er binnen de zorg verschillende CAO's. Dit leidt tot 
concurrentie tussen de verschillende zorginstellingen waarbij vooral de verzorgingstehuizen een zwakke positie hebben. Ten derde is er niet altijd sprake van een professioneel personeels- en opleidingsbeleid, waardoor de doorstroom- en carrièremogelijkheden gering zijn. Ten slotte ondervindt de zorg bij de vacatures voor automatiseerders sterke concurrentie van de ICT-sector.

Op termijn wordt er geen verbetering verwacht van de wervingsproblemen in de zorgsector. Op de middellange termijn worden voor de volgende beroepsgroepen problemen verwacht: huishoudelijke dagelijkse hulpen voor levensverzorging (niveau 2), helpenden op MBO-niveau (niveau 2), verzorgenden individuele gezondheidszorg op MBO-niveau (niveau 2), verpleegkundigen op MBO-niveau (niveau 4), HBO-verpleegkundigen, tandartsen en huisartsen. Mede als gevolg van de geringe instroom zullen er knelpunten in de personeelsvoorziening op middelbaar en hoger niveau voelbaar zijn. Daarnaast zal er een tekort zijn aan ervaren arbeidskrachten. Bij deze knelpunten speelt niet alleen de ontgroening een rol, maar ook het beperkte aantal opleidingsplaatsen. Een tweede belangrijke factor is de vergrijzing van de bevolking. Niet alleen leidt de vergrijzing van de beroepsbevolking tot een toenemende vervangingsbehoefte; door het toenemende aantal ouderen neemt ook de vraag naar zorg verder toe. Dit betekent dat de reeds jaren geldende numeri fixi, sluiting van opleidingsplaatsen en de verlenging van de opleidingsduur voor huisartsen op de arbeidsmarkt hun tol dreigen te gaan eisen.

Gediplomeerde schoolverlaters en 'stagiaires' zijn altijd een belangrijke doelgroep geweest in de personeelsvoorziening van de zorginstellingen. De werkgevers in de zorg moeten zich echter thans anders gaan opstellen bij de werving van schoolverlaters. Kwamen voorheen de afgestudeerden uit de inservice-opleiding in dienst; nu moeten de afgestudeerden geworven worden uit het reguliere onderwijs. De bredere opleiding bevordert echter de flexibiliteit en de mobiliteit aangezien jongeren sneller ingewerkt kunnen worden.

Direct inzetbaar personeel, met name schoolverlaters, wordt dus steeds schaarser. Dit betekent dat alternatieve wervingscategorieèn steeds meer in beeld komen. De ervaringen met deze groepen zijn veelal positief. In het algemeen geld echter wel dat voor het welslagen van de integratie van nieuw wervingscategorieèn er een intensieve begeleiding nodig is, dit zonodig gecombineerd met een opleidingstraject. Deze begeleiding dient zowel op de werkvloer als door de opleidings- of personeelsfunctionaris plaats te vinden. Met name herintredende vrouwen vormen voor veel verplegende en verzorgende functies een aantrekkelijke groep. Ook buitenlanders zijn goed inzetbaar. Er zijn diverse ervaringen met Belgische werknemers. Ook allochtonen zijn na een diploma-toets, een cursus Nederlandse taal en een zeer intensieve begeleiding goed inzetbaar. Zij zijn bovendien vaak zeer gemotiveerd en werken hard.

De zorgsector zoekt de oplossingen voor de (toekomstige) knelpunten vooral bij de instellingen zelf. Hierbij wordt gedacht aan het bevorderen van goed werkgeversschap (arbeidsvoorwaarden, opleidingsmogelijkheden, loopbaanbeleid, e.d.), het bevorderen van de mobiliteit, het vergroten van de functie-differentiatie, het openbreken van contracten en het bevorderen van contacten met ex-medewerkers en stagiaires. Gezamenlijk kan de zorgsector bijdragen aan het verbeteren van het imago van het werk in de sector, het intensiever samenwerken tussen bijvoorbeeld dokterspraktijken en zorginstellingen, het opzetten van 
pools voor waarnemers, nieuw arbeidsmarktonderzoek, e.d. Ook op het terrein van de relatie met het onderwijs zijn er mogelijkheden: het intensiveren van de contacten en de samenwerking, het voeren van een doelgroepenbeleid, het verbreden van de opleiding, het opstarten van verkorte opleidingen en deeltijdopleidingen, e.d.

\subsection{Omvang en samenstelling van de Limburgse arbeidsreserve}

\section{Inleiding}

De voorafgaande hoofdstukken van dit rapport hebben laten zien dat de Limburgse arbeidsmarkı in toenemende mate gekenmerkt wordt door een tekort aan direct inzetbaar personeel. Met name op MBO-niveau worden werkgevers geconfronteerd met grote knelpunten in de personeelsvoorziening. Gezien de verwachting dat deze knelpunten de komende jaren zullen voortduren, kan de vraag gesteld worden in hoeverre het bevorderen van de participatie van de niet-actieven in het arbeidsproces soelaas kan bieden. Vanuit deze optiek zal in deze paragraaf de omvang en samenstelling van de Limburgse beroepsbevolking en in het bijzonder de arbeidsreserve in kaart worden gebracht. De samenstelling wordt belicht vanuit drie gezichtspunten: geslacht, leeftijd en opleidingsniveau. Deze drie gezichtspunten geven een indicatie van de mogelijkheden om de arbeidsmarktparticipatie te verhogen in het licht van de knelpunten op de Limburgse arbeidsmarkt. Ten slotte wordt bekeken wat de perspectieven van de niet-actieve beroepsbevolking zijn op de Limburgse arbeidsmarkt gegeven het korte-termijn arbeidsmarktperspectief van de verschillende opleidingen in 1999.

\section{Omvang van en arbeidsmarktpositie van de Limburgse beroepsbevolking}

Startpunt vormt een indicatie van de non-participatie in Limburg. Tabel 5.1 geeft een overzicht van de arbeidsmarktpositie van de Limburgse en de Nederlandse beroepsbevolking. Uit de tabel blijkt dat de non-participatie in Limburg iets hoger is dan landelijk. In Limburg neemt ruim éénderde deel, dat wil zeggen bijna 300.000 mensen, van de bevolking tussen de 15 en de 64 jaar niet deel aan het arbeidsproces. Bovendien is 5\% van de beroepsbevolking, dat wil zeggen bijna 40.000 mensen, werkloos. Deze werkloosheid ligt op hetzelfde niveau als het landelijke percentage.

Tabel 5.1

Arbeidsmarktpositie potentiële beroepsbevolking, Nederland en Limburg, gemiddelde 1996-1997*

\begin{tabular}{|c|c|c|c|c|}
\hline & aantal & $\begin{array}{c}\text { werkzaam } \\
\%\end{array}$ & $\begin{array}{c}\text { werkloos } \\
\%\end{array}$ & $\begin{array}{c}\text { niet-participerend } \\
\%\end{array}$ \\
\hline Nederland & 10.617 .000 & 59 & 5 & 36 \\
\hline Limburg & 781.000 & 58 & 5 & 37 \\
\hline
\end{tabular}

* Opgemerkt dient te worden dat mensen die een voltijdsopleiding volgen niet in de analyse zijn betrokken. 


\section{Arbeidsmarktparticipatie naar geslacht en leeftijd}

In tabel 5.2 wordt inzicht gegeven in de omvang van de arbeidsreserve naar geslacht en leeftijd. Tussen de verschillende groepen blijken aanzienlijke verschillen in arbeidsmarktparticipatie te bestaan. Uit de tabel blijkt dat opvallend veel jongeren, die het initieel onderwijs reeds hebben verlaten, niet actief zijn op de arbeidsmarkt. Bijna 80.000 mensen jonger dan 30 jaar nemen niet deel aan het arbeidsproces en zijn ook niet actief op zoek naar een baan. Daarnaast zijn ongeveer 15.000 jongeren werkloos. Het is niet verrassend dat de arbeidsmarktparticipatie afneemt naarmate men ouder wordt. Slechts $45 \%$ van de Limburgse bevolking tussen de 50 en de 64 jaar heeft thans werk. Maar liefst de helft van deze leeftijdsgroep biedt zich niet (meer) aan op de arbeidsmarkt. De kans is groot dat zij door vervroegde uittreding of arbeidsongeschiktheid de arbeidsmarkt reeds definitief hebben verlaten. In dat geval zal het aanzienlijke inspanningen vergen deze groep te activeren en (opnieuw) klaar te stomen voor de arbeidsmarkt.

\section{Tabel 5.2}

Arbeidsmarktpositie potentiële beroepsbevolking naar geslacht en leeftijd, Limburg, gemiddelde 1996-1997

\begin{tabular}{cccc} 
aantal & $\begin{array}{c}\text { werkzaam } \\
\%\end{array}$ & $\begin{array}{c}\text { werkloos } \\
\%\end{array}$ & $\begin{array}{c}\text { niet-participerend } \\
\%\end{array}$ \\
\hline 212.000 & 56 & 7 & 37 \\
97.000 & 45 & 5 & 50 \\
399.000 & 75 & 6 & 19 \\
382.000 & 48 & 8 & 44
\end{tabular}

Bron: CBS/ROA

Het is niet verrassend dat de arbeidsmarktparticipatie onder mannen veel hoger is dan onder vrouwen. Slechts 19\% van de Limburgse mannen tussen de 15 en de 64 jaar heefi geen werk en zoekt ook niet actief naar werk. Bij de vrouwen is dit percentage veel hoger, namelijk 44\%. Dit betekent dat bijna 170.000 Limburgse vrouwen niet deelnemen aan het arbeidsproces. Daarnaast zijn ruim 30.000 Limburgse vrouwen werkloos.

Geconcludeerd kan worden dat er vanuit een macro-optiek duidelijk mogelijkheden bestaan om via een verhoging van de participatiegraad de krapte op de Limburgse arbeidsmarkt te verminderen. Met name door de participatie van jongeren en vrouwen te stimuleren kan het aanbod op de Limburgse arbeidsmarkı vergroot worden. Ook de arbeidsmarkiparticipatie onder ouderen is relatief laag. Wanneer zij echter door vervroegde uittreding of arbeidsongeschiktheid de arbeidsmarkt reeds definitief hebben verlaten, zal het aanzienlijke inspanningen vergen deze groep te activeren en (opnieuw) klaar te stomen voor de arbeidsmarkt. 


\section{De arbeidsmarktparticipatie naar opleidingsniveau}

De knelpunten op de Limburgse arbeidsmarkt worden met name ervaren bij de middelbare en hogere opleidingsniveaus. Dit betekent dat met name het activeren van de arbeidsreserve met een middelbare of hogere opleiding een effectief middel kan zijn om de knelpunten het hoofd te bieden. Lager opgeleiden zijn met name aantrekkelijk wanneer zij via gerichte scholing aan de door de werkgevers gestelde opleidingseisen kunnen voldoen.

In tabel 5.3 wordt een overzicht gegeven van de arbeidsmarktparticipatie naar opleidingsniveau. De tabel nuanceert het macro-beeld dat uit tabel 5.2 naar voren komt. Uit de tabel blijkt dat de non-participatie snel afneemt naarmate het opleidingsniveau hoger is. Uit de tabel valt af te leiden dat meer dan de helft van de niet-actieven een lagere opleidingsachtergrond (slechts basisonderwijs, een AVO- of een VBO-opleiding) hebben. Ook een groot deel van de werklozen is lager opgeleid. Gezien het feit dat vooral op middelbaar en hoger niveau knelpunten in de personeelsvoorziening worden ervaren, zal het stimuleren van de arbeidsmarktparticipatie van lager opgeleiden gepaard dienen te gaan met een omvangrijk scholingsprogramma. Dit betekent dat het bevorderen van de arbeidsmarktparticipatie van de Limburgse arbeidsmarktreserve aanzienlijke investeringen zal vergen. Dit neemt overigens niet weg dat mensen in Limburg die wel een middelbare of hogere opleiding gevolgd hebben en hetzij werkloos, hetzij niet-participerend zijn aantrekkelijk kunnen zijn voor werkgevers die te kampen hebben met grote knelpunten in de personeelsvoorziening. Dit zijn in totaal ongeveer 80.000 mensen.

Tabel 5.3

Arbeidsmarktpositie potentiële beroepsbevolking naar opleidingsniveau, Limburg, gemiddelde 1996-1997

\begin{tabular}{lcccc} 
Opleidingsniveau & aantal & werkzam & werkloos & niet-participerend \\
& & $\%$ & $\%$ & $\%$ \\
\cline { 2 - 5 } Basisonderwijs & 124.000 & 35 & 6 & 59 \\
MAVO/VBO & 224.000 & 55 & 5 & 40 \\
HAVO/VWO/BOL/BBL & 293.500 & 73 & 5 & 22 \\
HBO & 102.000 & 80 & 4 & 16 \\
WO & 27.500 & 86 & 6 & 8 \\
Totaal & & & & 37 \\
\end{tabular}

Bron: $C B S / R O A$

Uit tabel 5.2 kon worden geconcludeerd dat met name een verhoging van de arbeidsmarktparticipatie van jongeren en vrouwen een effectief middel zou kunnen zijn om de knelpunten op de Limburgse arbeidsmarkt te verminderen. Tabel 5.3 roept vervolgens de vraag op in hoeverre inzicht in de opleidingsachtergrond van de Limburgse beroepsbevolking aanleiding geeft om dit beeld te nuanceren. In tabel 5.4 wordt de opleidingsachtergrond van de Limburgse beroepsbevolking onder de 30 jaar in kaart gebracht. De tabel bevestigt het in tabel 5.3 geschetste beeld. De arbeidsmarktparticipatie neemt toe naarmate 
het opleidingsniveau toeneemt. Uit de tabel blijkt echter ook dat desondanks ruim 30.000 van de 95.000 niet-participerende of werkloze jongeren minimaal een middelbare opleiding heeft afgerond. De arbeidsmarktparticipatie van jongere VBO'ers en met name van jongeren met alleen Basisonderwijs is zeer laag. Dit beeld illustreert de zwakke positie van degenen die zonder startkwalificatie instromen op de arbeidsmarkt. Het bevorderen van de deelname van deze groep aan het arbeidsproces zal aanzienlijke inspanningen vragen.

Tabel 5.4

Arbeidsmarktpositie potentiële beroepsbevolking jonger dan 30 jaar naar opleidingsniveau, Limburg, gemiddelde 1996-1997

\begin{tabular}{lrrrr} 
Opleidingsniveau & aantal & $\begin{array}{c}\text { werkzaam } \\
\%\end{array}$ & $\begin{array}{c}\text { werkloos } \\
\%\end{array}$ & $\begin{array}{c}\text { niet-participerend } \\
\%\end{array}$ \\
\cline { 2 - 5 } Basisonderwijs & & & & \\
MAVO/NBO & 30.000 & 26 & 12 & 62 \\
HAVO/NWO/BOL/BBL & 67.000 & 47 & 6 & 47 \\
HBO & 83.500 & 71 & 6 & 23 \\
WO & 22.000 & 74 & 9 & 17 \\
& 5.500 & 76 & 14 & 10 \\
Totaal & 212.000 & 56 & 7 & 37
\end{tabular}

Bron: CBS/ROA

Tabel 5.5

Arbeidsmarktpositie potentiële beroepsbevolking ouder dan 50 jaar naar opleidingsniveau, Limburg, gemiddelde 1996-1997

Opleidingsniveau aantal werkzaam werkloos niet-participerend

\begin{tabular}{lrrrr}
\hline Basisonderwijs & 49.500 & 26 & 6 & 68 \\
MAVO/VBO & 60.500 & 38 & 5 & 57 \\
HAVO/VWO/BOL/BBL & 56.500 & 57 & 5 & 39 \\
HBO & 24.000 & 68 & 4 & 28 \\
WO & 5.000 & 80 & 4 & 16 \\
& & & & \\
Totaal & 197.000 & 45 & 5 & 50 \\
\hline
\end{tabular}

Bron: CBS/ROA

Zoals reeds eerder werd opgemerkt zal het perspectief voor ouderen om terug te keren in het arbeidsproces in veel gevallen waarschijnlijk gering zijn. Uit tabel 5.5 blijkt dat het relatief lage kwalificatieniveau van de oudere werkloze en niet-participerende Limburgers een extra belemmerende factor vormt. Ruim de helft van de oudere beroepsbevolking heeft een lagere opleiding. Ook het merendeel van de werklozen en niet-participerenden is laaggeschoold. Het stimuleren van de arbeidsmarktparticipatie van de ouderen zal derhalve 
aanzienlijke (scholings)investeringen vragen. Dit roept de vraag op in hoeverre deze investeringen opwegen tegen de baten, gezien het feit dat de tijd waarin de investeringen rendement op kunnen leveren kort zal zijn.

Tabel 5.2 liet zien dat ongeveer 200.000 Limburgse vrouwen tussen de 15 en de 64 jaar werkloos zijn of niet-participeren op de arbeidsmarkt. Uit tabel 5.6 blijkt dat de non-participatie ook onder hoger opgeleide vrouwen, met name op MBO-niveau, relatief hoog is. Dit betekent dat de vrouwelijke hoger opgeleide arbeidsreserve in Limburg relatief groot is. Ongeveer 52.000 Limburgse vrouwen hebben minimaal een opleiding op MBO-niveau afgerond en zijn thans niet actief op zoek naar een baan. Daarnaast zijn bijna 15.000 middelbaar en hoger opgeleide vrouwen werkloos. Tezamen vormen zij een potentieel van ruim 65.000 middelbaar en hoger opgeleiden. Het bevorderen van de arbeidsmarktparticipatie zal, naast eventuele investeringen in scholing, bijvoorbeeld gericht op herintredende vrouwen, vooral flankerend beleid zoals het bevorderen van de mogelijkheden voor kinderopvang vragen.

\section{Tabel 5.6}

Arbeidsmarktpositie vrouwen potentiële beroepsbevolking per opleidingsniveau, Limburg, gemiddelde 1996-1997

Opleidingsniveau aantal werkzaam werkloos niet-participerend

\begin{tabular}{lrrrr} 
& & $\%$ & $\%$ & $\%$ \\
\cline { 2 - 5 } Basisonderwijs & 65.500 & 20 & 8 & 71 \\
MAVO/VBO & 122.200 & 36 & 7 & 56 \\
HAVO/NWO/BOL/BBL & 137.500 & 62 & 8 & 31 \\
HBO & 45.000 & 75 & 6 & 19 \\
NO & 7.500 & 80 & 9 & 11 \\
Totaal & 382.000 & 48 & 8 & 44
\end{tabular}

Bron: $C B S / R O A$

Tabel 5.7

Arbeidsmarktpositie mannen potentiële beroepsbevolking per opleidingsniveau, Limburg, gem. 1996-1997

Opleidingsniveau aantal werkzaam werkloos niet-participerend

\begin{tabular}{lrrrr} 
& & $\%$ & $\%$ & $\%$ \\
\hline Basisonderwijs & 58.500 & 50 & 11 & 39 \\
MAVO/NBO & 102.000 & 72 & 6 & 23 \\
HAVONWO/BOLBBL & 156.000 & 82 & 4 & 14 \\
HBO & 57.000 & 86 & 4 & 10 \\
WO & 20.000 & 90 & 5 & 5 \\
Totaal & 399.000 & 75 & 6 & 19
\end{tabular}

Bron: CBS/ROA 
De arbeidsmarktparticipatie van mannen is relatief hoog, zoals tabel 5.2 liet zien. Slechts een kwart van de mannen is werkloos of niet-participerend. Dit zijn ongeveer 100.000 mannen tussen de 15 en de 64 jaar. Uit tabel 5.7 blijkt dat veel van deze mannen laag opgeleid zijn. Bij de middelbaar en hoger opgeleiden heeft meer dan $80 \%$ een baan. Dit betekent dat slechts 20.000 Limburgse mannen met een middelbare of hogere opleiding niet-participerend zijn. Daarnaast zijn 9.000 middelbaar en hoger opgeleide mannen werkloos. Voor de lager opgeleide werkloze en niet-participerende mannen - ongeveer 70.000 in getal zou alleen substantiële scholing, die hen op MBO-niveau brengt, soelaas kunnen bieden om over voldoende kwalificaties te kunnen beschikken om aan de eisen die door werkgevers gesteld worden te kunnen voldoen. Er kunnen echter kanttekeningen geplaatst worden bij de effectiviteit van dergelijke scholingsprogrammas aangezien de gemiddelde leeftijd van deze groep waarschijnlijk relatief hoog zal zijn en velen door arbeidsongeschiktheid de arbeidsmarkt hebben moeten verlaten.

\section{Non-participatie in relatie tot het arbeidsmarktperspectief}

In het voorafgaande is de nadruk gelegd op de samenstelling van de Limburgse arbeidsreserve. Er kan echter ook een relatie gelegd worden met het arbeidsmarktperspectief. Wanneer de non-participatie vooral hoog is bij dat deel van de beroepsbevolking dat op grond van zijn of haar opleidingsachtergrond weinig perspectief heeft op de arbeidsmarkt, dan zal het bevorderen van de participatie hetzij slechts een geringe bijdrage aan het verminderen van de knelpunten kunnen leveren, hetzij aanzienlijke scholingsinspanningen vragen om het potentiële aanbod in staat te stellen de veel gevraagde kwalificaties te verwerven.

Tabel 5.8

Percentage potentiële beroepsbevolking met een lagere of middelbare opleidingsachtergrond naar arbeidsmarktperspectief in 1999 en arbeidsmarktpositie

Arbeidsmarktpositie

goed perspectief

$\%$

62

56

Werkloos

Niet-participerend

Totaal
57

60 redelijk, matig of slecht perspectief

$\%$ 38

44

43

40

Bron: CBS/ROA

In tabel 5.8 wordt een overzicht gegeven van dat deel van de Limburgse beroepsbevolking dat een opleidingsachtergrond heeft waarvoor respectievelijk een goed of een redelijk tor slecht perspectief wordt verwacht. Het betreft hier uitsluitend de lager en middelbaar opgeleiden. Uit de tabel blijkt dat 60 procent van de lager en middelbaar opgeleide beroepsbevolking op basis van hun opleidingsachtergrond een goed perspectief heeft. Bij de werklozen en niet-participerenden ligt dit percentage iets lager. Dit is niet verrassend, gezien het 
hierboven geschetste beeld dat met name de niet-participerenden over het algemeen relatief laag zijn opgeleid.

In de tabellen 5.9 en 5.10 wordt de relatie tussen het arbeidsmarktperspectief voor 1999 en de participatiegraad per opleidingstype beschouwd. In tabel 5.9 wordt een overzicht gegeven van de opleidingstypen op MBO-niveau met een goed perspectief, waarbij een relatief gering deel van de beroepsbevolking (dat wil zeggen, minder dan $80 \%$ ) betaald werk heeft. Bevordering van de arbeidsmarktparticipatie kan voor deze segmenten van de arbeidsmarkt een effectief middel zijn om de knelpunten op de Limburgse arbeidsmarkt te verminderen. De tabel laat zien dat het hier vooral om opleidingen gaat die populair zijn bij vrouwen. Deze tabel bevestigt daarmee het hierboven geschetste beeld dat een vergroting van de arbeidsmarktparticipatie van goed opgeleide vrouwen een effectief middel kan zijn om de knelpunten op de Limburgse arbeidsmarkt te verminderen. Een uitzondering vormt de opleiding BOL/BBL bouw. Het hoge percentage niet-participerenden word voor dit opleidingstype mogelijk veroorzaakt door het hoge aantal arbeidsongeschikten. Dit betekent dat een vergroting van de arbeidsmarktparticipatie aanzienlijke inspanningen zal vergen in het verbeteren van de arbeidsmarktomstandigheden, het verminderen van de fysieke belasting, e.d.

Tabel 5.9

Opleidingstypen met een lage participatie en een goed arbeidsmarktperspectief voor 1999

Opleidingstype

Omvang potentiële

beroepsbevolking

werkzaam

$\%$

BOL/BBL uiterlijke verzorging

8.000

56

BOL/BBL verzorging

29.500

57

BOL/BBL secretariaat

8.500

59

BOL/BBL handel

30.000

64

BOL/BBL verpleging

13.500

BOL/BBL horeca

8.500

BOL/BBL bouw

10.000

Bron: ROA

In tabel 5.10 wordt een overzicht geven van de opleidingen op MBO-niveau met een goed arbeidsmarktperspectief voor 1999 en met een relatief hoog percentage werkenden. Deze opleidingstypen worden gekenmerkt door een hoge participatiegraad, hetgeen impliceert dat een bevordering van de arbeidsmarktparticipatie weinig soelaas zal bieden om het tekort aan direct inzetbare arbeidskrachten het hoofd te bieden. Uit de tabel blijkt dat het hier vooral om de technische opleidingen gaat die populair zijn bij mannen. Deze tabel bevestigt daarmee het hierboven geschetste beeld dat het bevorderen van de arbeidsmarktparticipatie van mannen slechts een gering effect op de knelpunten zal hebben. 
Tabel 5.10

Opleidingstypen met een hoge participatie en een goed arbeidsmarktperspectief voor 1999

Opleidingstype

Omvang potentiële

beroepsbevolking

werkzaam

$\%$

BOL/BBL motorvoertuigentechniek

$\begin{array}{rr}13.500 & 93 \\ 4.000 & 91 \\ 14.000 & 88 \\ 4.000 & 88 \\ 3.000 & 86 \\ 4.500 & 83 \\ 27.500 & 82 \\ 7.500 & 81 \\ 8.500 & 81\end{array}$

Bron: $R O A$

\subsection{Aandachtspunten voor het participatiebeleid}

Concluderend kan gesteld worden dat er 80 à 90.000 middelbaar en hoger opgeleide Limburgers niet participeren of werkloos zijn. Vanuit een macro-optiek vormen zij een aantrekkelijk potentieel om de tekorten aan direct inzetbaar personeel te verminderen. Deze groep bestaat met name uit vrouwen. Ongeveer 65.000 vrouwen hebben minimaal een opleiding op MBO-niveau afgerond, maar hebben thans geen betaald werk. Het bevorderen van de arbeidsmarktparticipatie zal, naast eventuele investeringen in scholing, bijvoorbeeld gericht op herintredende vrouwen, vooral flankerend beleid zoals het bevorderen van de mogelijkheden voor kinderopvang vragen. Er is ook een verrassend grote groep goed opgeleide jongeren die niet participeren op de Limburgse arbeidsmarkt. Ruim 30.000 middelbaar en hoger opgeleide Limburgers jonger dan 30 jaar heeft geen betaald werk. Deze groep overlapt natuurlijk de eerder genoemde vrouwen met minimaal een MBO-opleiding voor een belangrijk deel. Gezien het feit dat het potentieel aan goed opgeleide niet-actieven vooral uit vrouwen bestaat, kan het stimuleren van de arbeidsmarktparticipatie vooral in het licht van de tekorten aan zorgopgeleiden, secretarieel personeel, winkel- en horecapersoneel een effectieve maatregel zijn. De participatiegraad van technisch opgeleiden ligt op een veel hoger niveau. Het bevorderen van de arbeidsmarktparticipatie van technisch opgeleiden zal derhalve slechts een geringe bijdrage kunnen leveren aan het terugdringen van de knelpunten op de Limburgse arbeidsmarkt. 


\section{Scholing van werkzoekenden}

\subsection{Inleiding}

Bij- en omscholing van werkzoekenden kan een effectief middel zijn om discrepanties tussen vraag en aanbod op de arbeidsmarkt te verminderen. Door middel van bijscholing kunnen aansluitingsproblemen tussen de vaardigheden waarover de werkzoekenden in een bepaald arbeidsmarktsegment beschikken en de in dat segment gevraagde vaardigheden verminderd worden. Met andere woorden: bijscholing kan een effectief middel zijn om kwalitatieve aansluitingsproblemen in een bepaald arbeidsmarktsegment het hoofd te bieden. Daarentegen kunnen knelpunten op de arbeidsmarkt, die hun oorsprong vinden in het feit dat er in een specifiek arbeidsmarktsegment geen werkzoekenden beschikbaar zijn om aan de vraag te voldoen, verminderd worden door middel van omscholing. Omscholing van werkzoekenden op arbeidsmarktsegmenten waar sprake is van een overschot, kan dus een effectief middel zijn om kwantitatieve aansluitingsproblemen op andere arbeidsmarktsegmenten te verminderen.

De arbeidsmarktproblematiek kan grotendeels als een scholings- en trainingsvraagstuk beschouwd worden. Ondanks de verdergaande verkrapping van de arbeidsmarkt is er, vanuit een macro-economisch perspectief, in principe voldoende aanbod beschikbaar. Vaak sluiten de kwalificaties echter onvoldoende aan bij de eisen die door de vraagzijde van de arbeidsmarkt gesteld worden. Het gaat hierbij niet alleen om vakinhoudelijke vaardigheden, maar ook om werkhouding, communicatieve vaardigheden, de wil om te blijven leren, een klantgerichte instelling, e.d. Overigens dient benadrukt te worden dat ook het bedrijfsleven zelf een belangrijke rol kan spelen in het bij- en omscholen van de beroepsbevolking.

Bij- en omscholing nemen vanzelfsprekend enige tijd in beslag. Scholingsprogramma's zullen daarom het meest effectief zijn wanneer ze kunnen anticiperen op te verwachten toekomstige knelpunten. Wanneer het scholingsbeleid gebaseerd wordt op de huidige knelpunten op de arbeidsmarkt, bestaat het gevaar dat bij- en omgeschoolde werkzoekenden na afloop van hun scholingsperiode geconfronteerd worden met een gewijzigde arbeidsmarktsituatie waarin geen sprake meer is van een tekort aan arbeidskrachten met de kennis en vaardigheden die zij zojuist hebben verworven. Scholingsprogramma's zijn over het algemeen echter wel gericht op de korte termijn. Arbeidsvoorziening gaat er bijvoorbeeld van uit dat voor de werkzoekenden in fase 2 een scholingstraject van korter dan cen jaar voldoende kan zijn om een volwaardige plaats op de arbeidsmarkt te verwerven. Het ligt daarom erg voor de hand om arbeidsmarktprognoses voor de korte termijn als richtlijn te nemen voor het te voeren scholingsbeleid. Daarbij gaat het om een scholingsbeleid gericht op de discrepanties tussen vraag en aanbod op de arbeidsmarkt ${ }^{\prime 2}$.

32 Op de vraag of scholingsprogrammas om andere redenen - bijvoorbeeld in het licht van het doelgroe penbeleid - wenselijk of effectief zijn wordt in dit rapport niet ingegaan. 
In dit hoofdstuk wordt een raamwerk gepresenteerd dat richting kan geven aan een marktconform scholingsbeleid gericht op werkzoekenden. De opzet van dit hoofdstuk is in grote lijnen onveranderd ten opzichte van de RAIL-publicatie van vorig jaar ${ }^{33}$. Er is dit jaar echter gekozen voor een analyse van de bij- en omscholingsmogelijkheden naar beroepsgroep, aangezien de bij- en omscholingsprogramma's doorgaans gericht zijn op het beroep dat de werkzoekende na de bij- of omscholing zal gaan uitoefenen. Voor het te presenteren raamwerk wordt uitgegaan van de korte-termijnprognoses zoals die gepresenteerd zijn in hoofdstuk 4 van dit rapport. Drie indicatoren staan daarbij centraal. In de eerste plaats de Indicator Toekomstige Knelpunten in de Personeelsvoorziening naar Beroepsgroep (ITKB). Deze indicator geeft de verhouding weer tussen enerzijds de verwachte baanopeningen in 1999 en anderzijds het direct inzetbare arbeidsaanbod. Dit arbeidsaanbod heeft betrekking op de schoolverlaters en de direct bemiddelbare niet-werkende werkzoekenden, zoals die door Arbeidsvoorziening Limburg zijn ingedeeld in fase $1^{34}$. Vooral wanneer het verwachte aantal baanopeningen het aanbod overtreft kunnen marktconforme bij- en omscholingsprogrammas een effectief middel vormen om op deze verwachte knelpunten te anticiperen. Bij- en omscholing dient in dit kader overigens ruim te worden geïnterpreteerd. Het kan hierbij gaan om vakinhoudelijke scholing, maar bijvoorbeeld ook om het bieden van arbeidsmarktbegeleiding in meer ruime zin. Het karakter van de scholing dient afgestemd te zijn op het karakter van de aansluitingsproblematiek die lang niet altijd vakinhoudelijk van aard is.

De tweede indicator is een maatstaf voor de scholingsbehoefte. Deze indicator geeft het verschil weer tussen het totaal aantal openstaande vacatures en de verwachte baanopeningen en het direct inzetbare arbeidsaanbod. Met andere woorden: de scholingsbehoefte is gelijk aan de vraag die niet door het direct inzetbare aanbod kan worden vervuld.

De derde indicator heeft betrekking op het bijscholingspotentieel in verhouding tot de omvang van de scholingsbehoefte. Deze indicator geeft de verhouding weer tussen enerzijds het aantal openstaande vacatures en baanopeningen dat niet door het direct inzetbare aanbod kan worden ingevuld en anderzijds het aantal werkzoekenden met een wat grotere afstand tot de arbeidsmarkt, dat wil zeggen: de werkzoekenden zoals die door Arbeidsvoorziening Limburg zijn ingedeeld in fase 2 of $3^{\text {s'. }}$

Deze drie indicatoren bieden de mogelijkheid drie verschillende situaties te onderscheiden die elk een andere scholingsaanpak vragen ${ }^{\text {so: }}$

33 Zie hooldstuk 6. De Limburgse arbeidsmarkt 1997-2002

3t Zie voor meer bijzonderheden hoofdstuk + van dit rapport.

35. Aingezien de werkzockenden die ingedeeld zijn in lase 4 op korte termijn nies in aanmerking komen voor scholing, worden zij in dit hoofdstuk buten beschouwing gelaten.

36 Dit raamwerk is vergelijkbaar met het ramwerk dat in hoofdstuk 3 gebruikt is om de actuele discrepanties in kaart te brengen. De Indicator Tockomstige Knelpunten in de Personcelswoorziening is vergelijkbaar met de indicator voor de arbeidsmarktkrapte, terwijl de indicator van het bijscholingspotentieel in verhouding tot de omvang van de scholingsbehoefte het equivalent is van de knelpuntsindicator. 


\section{Een ruime arbeidsmarkt}

Een ruime arbeidsmarkt wordt gekenmerkt door een verwacht overschot aan direct inzetbare werkzoekenden. De Indicator Toekomstige Knelpunten in de Personeelsvoorziening naar Beroepsgroep (ITKB) is groter dan één. Dit betekent dat voor werkzoekenden met een grotere afstand tot de arbeidsmarkt de perspectieven gering zijn. In dat geval zal bijscholing (in ruime zin) op de korte termijn niet tot een vergroting van de arbeidsmarktkansen leiden. In deze arbeidsmarktsituatie is ook voor direct inzetbare werkzoekenden - schoolverlaters en werkzoekenden in fase 1 - het perspectief minder gunstig. Omscholing kan een middel zijn om de arbeidsmarktkansen voor deze werkzoekenden te vergroten.

\section{Een krappe arbeidsmarkt met een kwantitatief tekort}

Wanneer er sprake is van een tekort aan direct inzetbare werkzoekenden, terwijl er op het betreffende arbeidsmarktsegment ook onvoldoende werkzoekenden met een wat grotere afstand tot de arbeidsmarkt (in fase 2 of 3) beschikbaar zijn, is er sprake van een kwantitatief probleem. Er zijn eenvoudigweg te weinig werkzoekenden in het betreffende segment beschikbaar om in de totale behoefte te voorzien. Dit betekent dat de werkzoekenden in fase 2 en 3 door middel van bijscholing relatief snel aan een baan kunnen worden geholpen. De bijscholingsmogelijkheden voor deze niet-direct bemiddelbare werkzoekenden zijn daardoor groot. Bijscholing is daarentegen geen adequaat middel om de verwachte knelpunten op het betreffende arbeidsmarktsegment geheel het hoofd te bieden. De vraag zal het aanbod van arbeidskrachten blijven overtreffen. Omscholingsprogramma's voor werkzoekenden in verwante arbeidsmarktsegmenten waarin er sprake is van een ruime markt zijn derhalve noodzakelijk om in de totale vraag te voorzien.

\section{Een krappe arbeidsmarkt met een kwalitatief aansluitingsprobleem}

Wanneer het direct inzetbare aanbod tekortschiet om de verwachte baanopeningen in te vullen, maar er voldoende werkzoekenden in fase 2 en 3 op zoek zijn naar een baan in hel betreffende segment, is er sprake van een kwalitatief aansluitingsprobleem. In die situatic is bijscholing een effectief middel om in de vraag te voorzien. Gezien hel grote aantal werkzoekenden in fase 2 en 3 zijn de bijscholingsmogelijkheden voor de werkzoekenden zelf in dat geval echter relatief beperkt. De scholingsbehoefte aan de vraagkant van de arbeidsmarkt is immers relatief klein vergeleken met het aantal werkzoekenden in fase 2 en 3 Slechts een deel van de werkzoekenden met een wat grotere afstand tot de arbeidsmarkı kan via bijscholings- en begeleidingsprogramma's aan een baan worden geholpen. Scholing zal de werkloosheidsproblematiek in het betreffende segment dus slechts in beperkte mate verminderen.

Het hierboven geschetste raamwerk biedı de mogelijkheid de implicaties van de in 1999 verwachte knelpunten op de arbeidsmarkı voor het scholingsbeleid in kaart te brengen. Dit wordt gedaan voor de elementaire, lagere en middelbare beroepen. De arbeidsmarkt voor deze beroepsgroepen heeft een sterker regionaal karakıer dan de arbeidsmarkı voor de hogere beroepsgroepen. Voor de hogere beroepen is er daarentegen vaak sprake van een landelijke arbeidsmarkt. Bovendien is er vooralsnog een gebrek aan betrouwbare regionale instroomcijfers voor de hogere beroepen. 
De opzet van dit hoofdstuk is als volgt. In paragraaf 6.2 wordt nader ingegaan op de scholingsbehoefte aan de vraagkant van de arbeidsmarkt. In paragraaf 6.3 wordt vervolgens een typering gegeven van de verwachte arbeidsmarktsituatie in 1999. In paragraaf 6.4 wordt aandacht geschonken aan het gewenste karakter van de scholingsbehoefte in het licht van de arbeidsmarktsituatie en de gevraagde vaardigheden op de betreffende arbeidsmarktsegmenten. Dit hoofdstuk wordt in paragraaf 6.5 afgesloten met de belangrijkste conclusies in de vorm van een aantal aandachtspunten voor het in Limburg te voeren scholingsbeleid.

\subsection{Scholingsbehoefte op de Limburgse arbeidsmarkt}

\section{Krappe en ruime arbeidsmarktsegmenten}

Het onderscheid tussen krappe en ruime arbeidsmarkten vormt een geschikt startpunt voor het in kaart brengen van de scholingsbehoefte die voortvloeit uit de verwachte discrepanties tussen vraag en aanbod op de Limburgse arbeidsmarkt in 1999. De Indicator Toekomstige Knelpunten in de Personeelsvoorziening naar Beroepsgroep (ITKB) geeft per beroepsgroep een indicatie van de eventuele tekorten aan direct inzetbare werkzoekenden - d.w.z. schoolverlaters en niet-werkende werkzoekenden in fase 1 - in 1999. Wanneer de ITKB voor een bepaald beroep groter is dan één, dan wordt er voor deze beroepsgroep een ruime arbeidsmarkt verwacht. Er zal dan naar verwachting sprake zijn van hooguit enige knelpunten. In veel gevallen zullen werkgevers echter (vrijwel) niet met knelpunten geconfronteerd worden. Wanneer de ITKB daarentegen kleiner is dan één, dan zal er sprake zijn van een krappe arbeidsmarkt met grote tot zeer grote knelpunten. Het aantal direct inzetbare werkzoekenden schiet dan tekort om in de totale vraag op dat arbeidsmarktsegment in 1999 te voorzien.

De ITKB maakt het dus mogelijk een onderscheid te maken tussen ruime en krappe arbeidsmarktsegmenten. In paragraaf 4.4 is reeds aandacht geschonken aan de verwachte knelpunten in de personeelsvoorziening. In tabel 6.1 wordt een compleet overzicht gegeven van de beroepsgroepen waarvoor in 1999 een krappe arbeidsmarkt wordt verwacht ${ }^{37}$. Deze tabel is een uitbreiding van tabel 4.15. Bij vacatures waarvoor gezocht wordt naar iemand voor een beroep welke in de tabel word genoemd, zullen werkgevers in 1999 naar verwachting moeite hebben deze vacatures te vervullen, gezien het tekort aan direct inzetbare werkzoekenden. Er worden grote knelpunten in de personeelsvoorziening verwacht voor uiteenlopende beroepsgroepen. Zowel technische beroepen, economisch-administratieve beroepen, medische beroepen als dienstverlenende beroepen krijgen in Limburg naar verwachting te kampen met een krappe arbeidsmarkt in 1999.

37 In tabel $6.1 \mathrm{en}$ in ale rest van dit hoofdstuk wordt alleen aandacht geschonken aan een beroepsgroep wanneer er meer dan 2.500 mensen in het betreffende beroep werkzaam zijn in Limburg. 
Tabel 6.1

\section{Beroepsgroepen met naar verwachting een krappe arbeidsmarkt in 1999 in Limburg}

Beroepsgroep

Productieplanners

Ziekenverzorgenden

Confectie-arbeiders

Apothekersassistenten en medisch laboranten

Elektromonteurs

Juridisch en fiscaal medewerkers

Chauffeurs

Procesoperators

Metaalarbeiders

Winkeliers

Interieurverzorgers

Boekhouders en secretaresses

Mechanisch operators

Monteurs

Bankwerkers en lassers

Bouwvakkers

Verzorgend personeel

Verkopers

Programmeurs

Receptionisten en administratieve employees

Verplegenden en doktersassistenten

Aannemers en installateurs
ITKB

typering

knelpunten

$\begin{array}{ll}0,91 & \text { groot } \\ 0,93 & \text { groot } \\ 0,94 & \text { groot } \\ 0,95 & \text { groot } \\ 0,96 & \text { groot } \\ 0,97 & \text { groot } \\ 0,97 & \text { groot } \\ 0,97 & \text { groot } \\ 0,97 & \text { groot } \\ 0,98 & \text { groot } \\ 0,98 & \text { groot } \\ 0,98 & \text { groot } \\ 0,98 & \text { groot } \\ 0,98 & \text { groot } \\ 0,98 & \text { groot } \\ 0,98 & \text { groot } \\ 0,99 & \text { groot } \\ 0,99 & \text { groot } \\ 0,99 & \text { groot } \\ 0,99 & \text { groot } \\ 0,99 & \text { groot } \\ 0,99 & \text { groot } \\ & \\ 0,9 & \\ 0, & \end{array}$

Bron: $R O A$

\section{De scholingsbehoefte}

De scholingsbehoefte wordt gedefinieerd als het verschil tussen de verwachte baanopeningen en openstaande vacatures aan de ene kant en het verwachte aantal schoolverlaters en direct inzetbare werkzoekenden aan de andere kant. De scholingsbehoefte is van Iwee factoren afhankelijk. In de eerste plaats van de ernst van de verwachte knelpunten. Hoe groter de knelpunten, hoe groter de scholingsbehoefte vanuit werkgeversoptiek zal zijn. In de tweede plaats is de verwachte scholingsbehoefte afhankelijk van de omvang van het arbeidsmarktsegment. Hoe groter het arbeidsmarktsegment, hoe sterker knelpunten in de personeelsvoorziening zich manifesteren in een grote scholingsbehoefte.

In tabel 6.2 wordt een overzicht gegeven van de scholingsbehoefte vanuit de vraagzijde van de Limburgse arbeidsmarkt in 1999. Vier beroepsgroepen die wel in tabel 6.1 vermeld staan ontbreken hier. Voor de beroepen chauffeurs, mechanisch operators, receptionisten en administratieve employés en interieurverzorgers geldt dat, gezien het relatief lage niveau van de gevraagde kwalificaties, er minder behoefte zal bestaan aan vakinhoudelijke scholing. Uit 
de tabel blijkt dat de scholingsbehoefte ter voorkoming van knelpunten in de personeelsvoorziening zich naar verwachting richt op een diverse groep beroepen. De scholingsbehoefte is het grootst voor de beroepsgroep boekhouders en secretaresses. Door middel van het scholen van 700 werkzoekenden kan het verwachte tekort aan direct inzetbare werkzoekenden voor deze beroepsgroep worden voorkomen. Hier is het vooral de omvang van de markt - er zijn 27.000 mensen in dit beroep werkzaam in Limburg - die ten grondslag ligt aan de grote scholingsbehoefte. Ook bij de beroepsgroepen bouwvakkers, monteurs, verkopers en verzorgend personeel wordt de behoefte in belangrijke mate door de omvang van de markt bepaald. Bij de beroepsgroepen productieplanners, ziekenverzorgenden en confectiearbeiders wordt de omvang van scholingsbehoefte daarentegen vooral bepaald door de naar verwachting relatief grote knelpunten. De tabel laat tenslotte zien dat de totale scholingsbehoefte in Limburg 5.300 bedraagt. Zoals reeds eerder opgemerkt dient bij- en omscholing in dit kader overigens ruim te worden geïnterpreteerd. Bovendien dient te worden opgemerkt dat het hier alleen scholing ten behoeve van de het verminderen van de knelpunten in de lagere en middelbare beroepsgroepen betreft.

Tabel 6.2

Verwachte scholingsbehoefte naar beroepsgroep in 1999 in Limburg

Beroepsgroep

scholings- aantal opleidingstype

behoefte werkenden

Boekhouders en secretaresses

$700 \quad 27.000$

Productieplanners

$400 \quad 3.500$

Monteurs

350

17.000

BOL/BBL administratie, BOL/BBL secretariaat

BOL/BBL administratie

BOL/BBL motorv.techniek,

BOL/BBL werktuigb. en mech. techniek,

BOL/BBL elektrotechniek

Ziekenverzorgenden

$350 \quad 4.500$

Elektromonteurs

$300 \quad 7.500$

Bouwvakkers

250

14.000

Metaalarbeiders

$250 \quad 9.000$

Aannemers en installateurs

$200 \quad 9.000$

Confectie-arbeiders

$200 \quad 3.500$

Verkopers

200

21.000

Procesoperators

$150 \quad 5.500$

Apothekersass. en med. laborant

$150 \quad 3.000$

Winkeliers

150

8.500

Verzorgend personeel

150

14.000

Bankwerkers en lassers

$100 \quad 6.000$

7.500

BOL/BBL verzorging

BOL/BBL elektrotechniek

BOL/BBL bouw

verplegenden en doktersass.

100

3.500

BOL/BBL werktuigbouw en mech. techniek

Juridisch en fiscaal medewerkers

100

BOL/BBL bouw, BOL/BBL installatietechniek

BOL/BBL handel

BOLBBL handel

BOL/BBL procestechniek

BOL/BBL apothekersassistent

BOL/BBL handel

$B O L B B L$ verzorging,

BOLBBL uiterlijke verzorging

Programmeurs

$100 \quad 3.000$

BOL/BBL werktuigb. en mech. techniek

$B O U B B L$ verpleging

BOL/BBL geld, bank en belastingen,

BOLBBL administratie

BOL/BBL automatisering

Totaal 
In tabel 6.2 wordt tevens aangegeven welke opleidingsachtergrond het best aansluit op de gevraagde kwalificaties in de betreffende beroepsgroepen. Uit de tabel komt duidelijk naar voren dat de scholingsbehoefte vooral gericht is op opleidingen op MBO-niveau. Zo kunnen de knelpunten voor het beroep productieplanner voorna melijk voorkomen worden door het opschroeven van de scholingsinspanningen gericht op het het verwerven van kwalificaties die leiden tot een kwalificatieniveau dat gelijkwaardig is aan het opleidingstype BOL/BBL administratie. De scholingsbehoefte richt zich met name op technische opleidingen, zoals BOL/BBL elektrotechniek en BOL/BBL werktuigbouw en mechanische techniek, de administratieve opleidingen, de verzorgende en verplegende opleidingen en de bouw-opleidingen.

\subsection{Het bijscholingspotentieel in verhouding tot de bijscholingsbehoefte}

Bijscholing kan een belangrijk instrument zijn om de arbeidsmarktkansen van werkzoekenden die niet direct inzetbaar zijn te vergroten. De verwachte knelpunten in de personeelsvoorziening spelen vanzelfsprekend een belangrijke rol voor de bijscholingsmogelijkheden voor deze werkzoekenden. Wanneer er sprake is van een ruime arbeidsmarkt zijn er immers voldoende direct inzetbare werkzoekenden beschikbaar, waardoor scholing van de niet-direct inzetbare werkzoekenden weinig perspectiefvol is. Wanneer er daarentegen op een bepaald arbeidsmarktsegment sprake is van krapte en er grote knelpunten in de personeelsvoorziening verwacht worden, kan scholing de werkzoekenden met een grotere afstand tot de arbeidsmarkt een goed perspectief bieden op het vinden van werk.

Naast de vraag of er sprake is van verwachte knelpunten, speelt ook de aard van de knelpunten een rol. Wanneer voor een bepaalde beroepsgroep, waarvoor er sprake is van knelpunten in de personeelsvoorziening, ook het aantal werkzoekenden op dit arbeidsmarktsegment met een wat grotere afstand tot de arbeidsmarkt tekortschiet om de baanopeningen die niet door schoolverlaters en werkzoekenden in fase 1 kunnen worden vervuld in te vullen, dan is er, zoals reeds werd aangegeven in paragraaf 6.1, sprake van een kwantitatief tekort aan werkzoekenden. In dat geval zullen de bijscholingsmogelijkheden voor werkzoekenden in fase 2 en 3 naar verwachting groot zijn. De verhouding tussen het aantal nietdirect inzetbare werkzoekenden en de totale vraag die niet door schoolverlaters en werkzoekenden in fase 1 kan worden vervuld is dan kleiner dan één.

In tabel 6.3 wordt een overzicht gegeven van de beroepsgroepen die gekenmerkt worden door goede bijscholingsmogelijkheden voor werkzoekenden op hun arbeidsmarktsegment met een grotere afstand tot de arbeidsmarkt. Uit de tabel blijkt dat de bijscholingsmogelijkheden voor de niet-direct bemiddelbare werkzoekenden het grootst zijn voor zickenverzorgenden, confectie-arbeiders, juridisch en fiscaal medewerkers en productieplanners. Voor elke honderd baanopeningen in deze beroeps groepen die niet door schoolverlaters of direct bemiddelbare werkzoekenden kunnen worden vervuld, zijn er slechts 0 tol 5 niel-direct inzetbare werkzoekenden beschikbaar. Voor de werkzoekenden in fase 2 en 3 in deze beroepsgroepen zijn de bijscholingsperspectieven derhalve groot. Bijscholing is daardoor een effectief middel om de arbeidsmarktkansen van deze werkzoekenden te vergroten. Naast de genoemde beroepsgroepen geldt dit bijvoorbeeld ook voor apothekersassistenten en medisch laboranten, elektromonteurs, programmeurs en winkeliers. 
Bovenstaande toont weliswaar aan dat bijscholing effectief is voor niet-direct bemiddelbare werkzoekenden in deze beroepsgroepen, maar welk karakter de bijscholing dient te hebben is echter niet duidelijk. Met andere woorden: de onderliggende oorzaken van het feit dat deze werkzoekenden een grotere afstand tot de arbeidsmarkt hebben worden uit deze cijfers niet duidelijk. Mogelijk hebben deze werkzoekenden een te laag opleidingsniveau of een te geringe werkervaring om direct goed inzetbaar te zijn. Dit laatste zou overigens betekenen dat niet alleen aanvullende scholing, maar ook het creêren van mogelijkheden om op de werkvloer ervaring op te doen belangrijk is om het beschikbare aanbod van werkzoekenden direct bemiddelbaar te maken.

In het eerste RAIL-rapport werd de scholingsproblematiek nog vanuit een opleidingsperspectief benaderd. Enkele van de opleidingstypen, welke toen met een kwalitatief probleem geconfronteerd werden, zien we vanuit het perspectief van de beroepsgroepen nu in feite terug. Dit geldt met name voor de opleidingstypen elektrotechniek, motorvoertuigentechniek, procestechniek en bouw op MBO-niveau. Deze komen in tabel 6.3 voor bij de beroepsgroepen (elektro)monteurs, procesoperators, en aannemers en installateurs. De problemen die voor 1998 werden verwacht zijn klaarblijkelijk niet opgelost.

In tabel 6.3 wordt tevens aangegeven welk karakter de bijscholing zou dienen te hebben om zo goed mogelijk aan te sluiten bij de (vakinhoudelijke) lacunes van de werkzoekenden op het betreffende arbeidsmarktsegment. Bij de middelbare technische functies, zoals de procesoperators en metaalarbeiders, worden zowel het te lage opleidingsniveau als de te geringe werkervaring genoemd als een oorzaak van het moeilijk kunnen vervullen van de vacatures. Voor het te voeren arbeidsvoorzieningsbeleid betekent dit dat niet alleen aanvullende scholing, maar ook het creëren van mogelijkheden om op de werkvloer ervaring op te doen belangrijk is om het beschikbare anbod van werkzoekenden direct bemiddelbaar te maken. In de voor de bouw relevante functies, zoals aannemers en installateurs, ontbreekt vooral de vereiste werkervaring. Ook in dit geval is het creëren van mogelijkheden om in de praktijk werkervaring op te doen een geschikt instrument. De monteurs hebben daarentegen vaak niet de juiste opleidingsrichting voor de moeilijk vervulbare vacatures. Aanvullende cursussen om de kennis te verbreden zijn hier dus gewenst. Voor de functies in de handel, zoals confectie-arbeiders en winkeliers, blijkt vooral productkennis van groot belang te zijn. Branchegerichte opleidingstrajecten kunnen hierbij een effectief middel zijn. In de zorgberoepen, zoals de ziekenverzorgenden, speelt vooral het ontbreken van opleidingsplaatsen en de tijd en mogelijkheden om mensen intensief te begeleiden een rol. Het creèren van mogelijkheden om mensen ervaring op te laten doen zijn derhalve ook hier erg belangrijk. Ten slote wijzen de werkgevers in de ICT-sector erop dat het omscholen van werkzockenden tot programmeur geen afdoende middel is, aangezien er ook in deze beroepsgroep een grote behoefte bestaat aan ervaring. 


\section{Tabel 6.3}

\section{Beroepsgroepen met naar verwachting goede bijscholingsmogelijkheden (BSM) voor individuele werkzoekenden in 1999 in Limburg}

\begin{tabular}{|c|c|c|c|}
\hline Beroepsgroep & BSM & BOL/BBL-opleidingstype & aard bijscholing \\
\hline Confectie-arbeiders & 0 & handel & productkennis vergroten \\
\hline Juridisch en fiscaal medewerkers & 0 & $\begin{array}{l}\text { geld, bank en belastingen, } \\
\text { administratie }\end{array}$ & kennis actualiseren \\
\hline Ziekenverzorgenden & 0,04 & verzorging & ervaring opdoen \\
\hline Productieplanners & 0,05 & administratie & $\cdot$ \\
\hline Apothekersass./med.laboranten & 0,09 & apothekersassistent & - \\
\hline Elektromonteurs & 0,10 & elektrotechniek & vakkennis vergroten \\
\hline Programmeurs & 0,17 & automatisering & $\begin{array}{l}\text { vakkennis vergroten } \\
\text { ervaring opdoen }\end{array}$ \\
\hline Winkeliers & 0,18 & handel & productkennis vergroten \\
\hline Monteurs & 0,29 & $\begin{array}{l}\text { motorvoertuigentechniek, } \\
\text { werktuigb. en mech. } \\
\text { techniek, elektrotechniek }\end{array}$ & vakkennis verbreden \\
\hline Metaalarbeiders & 0,30 & werktuigb. en mech. techniek & $\begin{array}{l}\text { niveau verhogen } \\
\text { ervaring opdoen }\end{array}$ \\
\hline Procesoperators & 0,56 & procestechniek & $\begin{array}{l}\text { niveau verhogen } \\
\text { ervaring opdoen }\end{array}$ \\
\hline Aannemers en installateurs & 0,86 & bouw, installatietechniek & ervaring opdoen \\
\hline
\end{tabular}

Bron: ROA

Knelpunten in de personeelsvoorziening kunnen ook het gevolg zijn van een kwalitaticf aansluitingsprobleem bij een bepaald beroep. In dat geval zijn er voor die beroepsgroep voldoende werkzoekenden in fase 2 en 3 beschikbaar om de baanopeningen die niet door schoolverlaters en werkzoekenden in fase 1 kunnen worden vervuld in te vullen. Deze werkzoekenden voldoen echter niet aan de eisen die op het betreffende arbeidsmarktsegment worden gesteld. Het probleem is dus kwalitatief van aard. De indicator voor het bijscholingspotentieel in verhouding tot de scholingsbehoefte is dan groter dan éen. Daardoor zal slechts een deel van de werkzoekenden in fase 2 en 3 door bijscholing een baan kunnen krijgen.

In tabel 6.4 wordt een overzicht gegeven van de beroepsgroepen waarvoor er sprake is van een kwalitatief aansluitingsprobleem, waardoor de bijscholingsmogelijkheden voor individuele werkzoekenden die zijn ingedeeld in fase 2 of 3 dus relatief beperkt zijn. Uit de tabel blijkı dat deze situatie zich in 1999 naar verwachting voor een zestal beroepsgroepen zal voordocn. Voor bouwvakkers geldt dat voor elke 100 baanopeningen, die niet door direct inzethare werkzoekenden kunnen er worden ingevuld, er 142 werkzoekenden in fase 2 en 3 beschikbaar zijn. Van deze 142 werkzoekenden kunnen er dus naar verwachting 100 door middel van bijscholing aan het werk worden geholpen. De rest zal niet door bijscholing aan een baan binnen deze beroepsgroep kunnen worden geholpen. Vanuit het gezichtspunt van de werkzoekenden biedt bijscholing voor de beroepsgroep verkopers het geringste perspectief. 
Er zijn meer dan 600 werkzoekenden met een zekere afstand tot de arbeidsmarkt beschikbaar op elke 100 baanopeningen waarvoor geen direct-inzetbare werkzoekenden beschikbaar zijn. In tabel 6.2 vinden we voor verkopers een scholingsbehoefte van 200. Na bijscholing van 200 werkzoekenden, blijven er dus maar liefst ongeveer 1.000 werkzoekenden over die niet op dit arbeidsmarktsegment kunnen worden ingezet. Zonder omscholing is er voor deze groep werkzoekenden in 1999 naar verwachting geen plaats op de Limburgse arbeidsmarkt.

In het eerste RAIL-rapport waren er slechts twee opleidingstypen met een kwalitatief aansluitingsprobleem, namelijk BOL/BBL secretariaat en BOL/BBL automatisering. BOL/BBL secretariaat komt in tabel 6.4 weer terug via de beroepsgroep boekhouders en secretaresses. De arbeidsmarkt voor BOL/BBL automatisering, met name programmeurs, zal naar verwachting verder verkrappen. Als gevolg hiervan zal dit arbeidsmarktsegment, zoals tabel 6.3 liet zien, in 1999 naar verwachting niet met een kwalitatief probleem, maar met een kwantitatief probleem te kampen hebben.

\section{Tabel 6.4}

\begin{tabular}{|c|c|c|c|}
\hline Beroepsgroep & BSM & BOL/BBL-opleidingstype & aard bijscholing \\
\hline Bouwvakkers & 1,42 & bouw & ervaring opdoen \\
\hline Bankwerkers en lassers & 1,66 & werktuigb. en mech. techniek & $\begin{array}{l}\text { niveau verhogen } \\
\text { ervaring opdoen }\end{array}$ \\
\hline Verzorgend personeel & 2,89 & verzorging, uiterlijke verzorging & ervaring opdoen \\
\hline Boekhouders en secretaresses & 3,00 & adminisțratie, secretariaat & kennis actualiseren \\
\hline Verplegenden en doktersass. & 3,58 & verplegingkennis actualiseren & ervaring opdoen \\
\hline Verkopers & 6,29 & handel & productkennis vergroten \\
\hline
\end{tabular}

Bron: ROA

Zoals reeds eerder is opgemerkt ontbreekt bij de werkzoekende bouwvakkers en bankwerkers en lassers vooral de vereiste werkervaring. In dit geval is het creëren van mogelijkheden om in de praktijk werkervaring op te doen een geschikt instrument. Daarnaast is het verhogen van het kwalificatieniveau van de bankwerkers en lassers van groot belang. In de zorgberoepen, zoals de verplegenden en doktersassistenten en het verzorgend personeel, speelt vooral het ontbreken van opleidingsplaatsen en de tijd en mogelijkheden om mensen intensief te begeleiden een rol. Het creeren van mogelijkheden om mensen ervaring op te laten doen zijn derhalve ook hier erg belangrijk. Voor de functies in de handel, zoals verkopers, blijkt vooral productkennis van groot belang te zijn. Branchegerichte opleidingstrajecten kunnen hierbij een effectief middel zijn. Een tekort aan gekwalificeerde secretaresses wordt als belangrijkste oorzaak voor het moeilijk vervulbaar zijn van vacatures voor deze berocpsgroep genocmd. Blijkbaar hebben de niet direct inzetbare werkzoekenden een dermate grote afstand tot de arbeidsmarkt dat zij door de vraagzijde van de markt zelfs niet als potentieel aambod worden beschouwd. Dit betekent dat de te verrichten scholingsin- 
spanningen per werkzoekende in dit segment aanzienlijk dienen te zijn. Het gaat hier waarschijnlijk vooral om herintreders die qua kennis en vaardigheden niet goed inzetbaar zijn in de openstaande vacatures voor secretariaatsfuncties. De bijscholing van deze werkzoekenden zal waarschijnlijk met name moeten worden gericht op het kunnen werken met tekstverwerkingspakketten en andere relevante softwarepakketten.

\subsection{Het karakter van de scholingsbehoefte}

Naast de in paragraaf 6.2 besproken omvang van de scholingsbehoefte is ook van belang waar de werkzoekenden die voor scholing in aanmerking komen gevonden kunnen worden. Hierbij kan, zoals bij de bijscholingsmogelijkheden voor werkzoekenden, een onderscheid gemakkt worden tussen beroepsgroepen waarvoor er sprake is van een kwalitatief aansluitingsprobleem en beroepsgroepen die gekenmerkt worden door een kwantitatief aanbodtekort. Wanneer er sprake is van een kwalitatief aansluitingsprobleem kan de nadruk liggen op bijscholing van niet-direct inzetbare werkzoekenden in het eigen segment. Dit is het geval voor de in tabel 6.4 genoemde beroepsgroepen. Er zijn meer dan voldoende werkzoekenden in fase 2 en 3 in deze beroepen beschikbaar om op het verwachte tekort aan schoolverlaters en werkzoekenden in fase $l$ op het desbetreffende arbeidsmarktsegment te anticiperen door middel van bijscholing.

Wanneer er sprake is van een kwantitatief aansluitingsprobleem is bijscholing van de nietdirect inzetbare werkzoekenden voor het betreffende beroep echter niet toereikend om de verwachte knelpunten in de personeelsvoorziening te voorkomen. In dat geval is omscholing van werkzoekenden op een enigszins verwant beroeps segment noodzakelijk om in de vraag te voorzien. Deze mensen zullen vanzelfsprekend moeten worden aangetrokken uit arbeidsmarktsegmenten waarvoor geen knelpunten in de personeelsvoorziening verwacht worden. Het omscholen van arbeidskrachten uit segmenten waarvoor eveneens sprake is van knelpunten is immers weinig efficiënt.

In tabel 6.5 wordt voor de beroepsgroepen die naar verwachting in 1999 te kampen zullen hebben met een kwantitatief aanbodtekort aangegeven welke werkzoekenden (mits opgeleid voor een verwant beroep) voor omscholing in aanmerking zouden kunnen komen. Er wordt aangegeven op welke beroepsgroepen deze scholing gericht zou dienen te zijn. Voor beroepsgroepen waarvoor geen werkzoekenden uit verwante beroepsgroepen beschikbaar zijn biedı scholing echter op de korte termijn geen soelaas om de knelpunten in de personeelsvoorziening te verminderen. Dit kan twee oorzaken hebben. Ten eerste kan er bij verwante beroepsgroepen ook sprake zijn van knelpunten in de personeelsvoorziening. Zo zijn de beroepsgroepen verkopers, confectie-arbeiders en winkeliers nauw aan elkaar verwant en deze beroepsgroepen zullen alle drie in 1999 naar verwachting worden gekenmerkı door grote knelpunten in de personeelsvoorziening. Hetzelfde geld t voor een andere groep vergelijkbare beroepen; monteurs, elektromonteurs, metaalarbeiders en aannemers en installateurs. Dit betekent dat de omscholingsmogelijkheden vooral gezocht moeten worden in het substantieel verhogen van het kwalificatieniveau van laaggeschoolden en het stimuleren van de arbeidsmarktparticipatie van goed gekwalificeerde jongeren en vrouwen, zoals geschetst in hoofdstuk 5. Een belangrijke uitzondering vormt de zorgsector, waar bij de lagere beroepen verpleeghulpen en leerling-verpleegkundigen sprake is van een ruime arbeidsmarkt. Het omscholen van werkzoekenden in deze beroepsgroepen tot ziekenverzorgende of 
apothekersassistente kan de knelpunten in deze beroepsgroepen doen verminderen. Een tweede uitzondering vormt het cluster van monteursberoepen waar bijvoorbeeld bij de elektrotechnici en de controleurs elektrotechnische producten de arbeidsmarkt voldoende ruim is om de tekorten bij de (elektro)monteurs door middel van omscholingstrajecten te verminderen.

Tabel 6.5

Mogelijkheden ter voorkoming van de knelpunten in de personeelsvoorziening door middel van omscholing in 1999 in Limburg

\begin{tabular}{|c|c|c|}
\hline Beroepsgroep & omscholing vanuit & BOL/BBL opleidingstype \\
\hline Confectie-arbeiders & - & handel \\
\hline Juridisch en fiscaal medewerkers & - & $\begin{array}{l}\text { geld, bank en belastingen, } \\
\text { administratie }\end{array}$ \\
\hline Ziekenverzorgenden & $\begin{array}{l}\text { verpleeghulpen en } \\
\text { leerlingverpleegkundigen }\end{array}$ & verzorging \\
\hline Productieplanners & 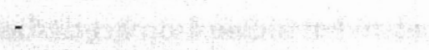 & administratie \\
\hline Apothekersass./med.laboranten & $\begin{array}{l}\text { verpleeghulpen en } \\
\text { leerlingverpleegkundigen }\end{array}$ & apothekersassistent \\
\hline Elektromonteurs & $\begin{array}{l}\text { elektrotechnici, monteurs en } \\
\text { controleurs elektratechn. producten }\end{array}$ & elektrotechniek \\
\hline Programmeurs & - & automatisering \\
\hline Winkeliers & - & handel \\
\hline Monteurs & $\begin{array}{l}\text { elektrotechnici, monteurs en } \\
\text { controleurs elektrotechn. producten }\end{array}$ & $\begin{array}{l}\text { motorvoertuigentechniek, } \\
\text { werktuigb. } \\
\text { en mech. techniek, } \\
\text { elektrotechniek }\end{array}$ \\
\hline Metaalarbeiders & - & werktuigb. en mech. techniek \\
\hline Procesoperators & - & procestechniek \\
\hline Aannemers en installateurs & - & bouw, installatietechniek \\
\hline
\end{tabular}

Bron: ROA

\section{Uitgelicht: monteurs}

Startpunt voor het in kaart brengen van de effectiviteit van het scholingsinstrument voor de beroepsgroep monteurs vormen de verwachte arbeidsmarktontwikkelingen op de korte termijn. De verwachte arbeidsmarktontwikkeling voor 1999 is opgebouwd uit twee delen: de verwachte vraag en het verwachte aanbod. De vraag (baanopeningen) wordt uitgesplitst in uitbreidingsvraag en vervangingsvraag. De uitbreidingsvraag geeft de werkgelegenheidsontwikkeling weer, terwijl de vervangingsvraag voortkomt uit vertrek van personeel door bijvoorbeeld - al dan niet vervroegde - pensionering, arbeidsongeschiktheid, tijdelijke terugtreding en beroepsmobiliteit. Beide vraagcomponenten worden voorgesteld als een percentage van de werkgelegenheid, in het geval van de monteurs zijn dit in Limburg 17.000 werkenden. Voor monteurs geldt een uitbreidingsvraag van $0,4 \%$ en een vervangingsvraag van $3,4 \%$ van de werkgelegenheid. Deze worden respectievelijk getypeerd als 
'laag' en 'gemiddeld' en resulteren in baanopeningen ter grootte van 3,8\% van de werkgelegenheid, hetgeen als 'gemiddeld' wordt getypeerd (tabellen 3.2, 3.3 en 3.4 van de Statistische Bijlage). Tegenover de vraag staat het aanbod. Deze wordt gegeven door de verwachte arbeidsmarktinstroom. Voor monteurs geldt voor 1999 een verwachte arbeidsmarktinstroom van 1,6\% van de werkgelegenheid (tabel 3.5 van de Statistische Bijlage). Dit percentage is vergeleken met de verwachte arbeidsmarktinstroom van andere beroepsgroepen relatief laag. Het confronteren van vraag- en aanbodstromen geeft de Indicator Toekomstige Knelpunten in de personeelsvoorziening naar Beroepsgroep (ITKB). Deze indicator wordt gepresenteerd in tabel 3.6 van de Statistische Bijlage. Het feit dat de vraag naar verwachting kleiner is dan het aanbod en dat de ITKB met 0,98 dus kleiner is dan éen, duidt op grote knelpunten. Werkgevers zullen naar verwachting veel moeite ondervinden bij het werven van monteurs.

De verwachte discrepanties tussen vraag en aanbod op de arbeidsmarkt voor monteurs in Limburg in 1999 resulteren in een aanzienlijke scholingsbehoefte. Het verschil tussen de verwachte baanopeningen en de openstaande vacatures aan de ene kant en de verwachte schoolverlaters en direct inzetbare werkzoekenden aan de andere kant bedraagt voor monteurs in 1999 naar verwachting 350 (tabel 6.2). De verhouding tussen het aantal openstaande vacatures en baanopeningen dat niet door het direct inzetbare aanbod kan worden vervuld enerzijds en het aantal werkzoekenden met een wat grotere afstand tot de arbeidsmarkt anderzijds, geeft de bijscholingsmogelijkheden aan. De bijscholingsmogelijkheden (BSM) geven in feite de mate van concurrentie aan die werkzoekenden in fase 2 en 3 zullen ondervinden in de competitie om de vacatures die niet door de direct-inzetbare werkzoekenden zijn opgevuld. In tabel 6.3 zien we dat de bijscholingsmogelijkheden voor monteurs goed zijn, met een BSM van 0,29. Voor elke honderd baanopeningen die niet door schoolverlaters of direct bemiddelbare werkzoekenden kunnen worden vervuld, zijn er slechts 29 niet-direct inzetbare werkzoekenden beschikbaar. De bijscholing van deze groep overgebleven werkzoekenden zal met name gericht moeten zijn op het verbreden van de vakkennis van werkzoekenden met een technische opleidingsachtergrond. Te denken valt aan de opleidingen BOL/BBL motorvoertuigentechniek, BOL/BBL werktuigbouw en mechanische techniek en BOL/BBL elektrotechniek (tabel 6.3). Aangezien er sprake is van een kwantitatief aansluitingsprobleem - de knelpuntsindicator is groter dan één - is bijscholing van de niet-direct inzetbare werkzoekenden voor monteurs niet toereikend om de verwachte knelpunten in de personeelsvoorziening te voorkomen. Omscholing van werkzoekenden op een enigszins verwant beroepssegment is noodzakelijk om in de vraag te voorzien. Vanzelfsprekend dienen deze mensen te worden aangetrokken uit arbeidsmarktsegmenten waarvoor geen knelpunten in de personeelsvoorziening worden verwacht. Voor monteurs betekent dit omscholing vanuit de beroepsgroepen elektrotechnici en monteurs en controleurs elektrotechnische producten (tabel 6.5).

\subsection{Aandachtspunten voor het scholingsbeleid}

Bij-en omscholing van werkzoekenden kan een effectief middel zijn om discrepanties tussen vraag en aanbod op de arbeidsmarkt te verminderen. Door middel van bijscholing kunnen aansluitingsproblemen tussen de kennis en vaardigheden waarover de werkzoekenden op een bepaald arbeidsmarktsegment beschikken en de in dat segment gevraagde kennis en vaardigheden verminderd worden. Met andere woorden: bijscholing kan een 
effectief middel zijn om kwalitatieve aansluitingsproblemen in een bepaald arbeidsmarktsegment het hoofd te bieden. Door middel van omscholing kunnen knelpunten op de arbeidsmarkt, die hun oorsprong vinden in het feit dat er in een specifiek arbeidsmarktsegment geen werkzoekenden beschikbaar zijn om aan de vraag te voldoen, verminderd worden. Omscholing van werkzoekenden die zijn opgeleid voor een beroepsgroep waarvoor er sprake is van een overschot, kan dus een effectief middel zijn om kwantitatieve aansluitingsproblemen op andere arbeidsmarktsegmenten te verminderen.

Aansluitingsproblemen hebben overigens niet alleen betrekking op vakinhoudelijke kennis en vaardigheden. Ook werkhouding, communicatieve vaardigheden, de wil om te blijven leren, een klantvriendelijke instelling, e.d. spelen een belangrijke rol.

De scholingsinspanningen zullen zich naar verwachting concentreren op het vergroten van het direct inzetbare arbeidsaanbod in beroepsgroepen uit de segmenten techniek, bouw, zorg, administratie en secretariaat. Voor de beroepsgroepen met een kwalitatief aansluitingsprobleem is vooral de aansluiting tussen gevraagde en aangeboden kwalificaties een probleem. Bijscholing van werkzoekenden met een grotere afstand tot de arbeidsmarkt zou de in 1999 verwachte knelpunten in de personeelsvoorziening in deze beroepen kunnen voorkomen. Bij de werkzoekende bouwvakkers en bankwerkers en lassers ontbreekt vooral de vereiste werkervaring. In dit geval is het creëren van mogelijkheden om in de praktijk werkervaring op te doen een geschikt instrument. Daarnaast is het verhogen van het kwalificatieniveau van de bankwerkers en lassers van groot belang. In de zorgberoepen, zoals de verplegenden en doktersassistenten en het verzorgend personeel, speelt vooral het ontbreken van opleidingsplaatsen en de tijd en mogelijkheden om mensen intensief te begeleiden een rol. Het creëren van mogelijkheden om mensen ervaring op te laten doen zijn derhalve ook hier erg belangrijk. Voor de functies in de handel, zoals verkopers, blijkt vooral productkennis van groot belang te zijn. Branchegerichte opleidingstrajecten kunnen hierbij een effectief middel zijn. Een tekort aan gekwalificeerde secretaresses wordt als belangrijkste oorzaak voor het moeilijk vervulbaar zijn van vacatures voor deze beroepsgroep genoemd. Blijkbaar hebben de niet-direct inzetbare werkzoekenden een dermate grote afstand tot de arbeidsmarkt dat zij door de vraagzijde van de markt zelfs niet als potentieel aanbod worden beschouwd. Dit betekent dat de te verrichten scholingsinspanningen per werkzoekende in dit segment aanzienlijk dienen te zijn. Het gaat hier waarschijnlijk vooral om herintreders die qua kennis en vaardigheden niet goed inzetbaar zijn in de openstaande vacatures voor secretariaatsfuncties. De bijscholing van deze werkzoekenden zal waarschijnlijk met name moeten worden gericht op het kunnen werken met tekstverwerkingspakketten en andere relevante softwarepakketten.

Voor cen aantal beroepsgroepen wordt een kwantitatief aansluitingsprobleem verwacht. Zo wordt er in 1999 een tekort van 400 aan direct inzetbaar aanbod van productieplanners verwacht; cen tekort van 350 monteurs en ziekenverzorgenden en een tekort van 300 elektromontcurs. In deze gevallen zal alleen een combinatie van bij- en omscholingstrajecten soclaas kunnen bieden. Bij de middelbare technische functies, zoals de procesoperators en metaalabeiders, worden zowel het te lage opleidingsniveau als de te geringe werkervaring genoemd als oorzaken van het moeilijk kunnen vervullen van de vacatures. Voor het te voeren arbeidsvoorzieningsbeleid betekent dit dat niet alleen aanvullende scholing, maar ook het creëren van mogelijkheden om op de werkvloer ervaring op te doen belangrijk is 
om het beschikbare aanbod van werkzoekenden direct bemiddelbaar te maken. In de voor de bouw relevante functies, zoals aannemers en installateurs, ontbreekt vooral de vereiste werkervaring. Ook in dit geval is het creëren van mogelijkheden om in de praktijk werkervaring op te doen een geschikt instrument. De monteurs hebben daarentegen vaak niet de juiste opleidingsrichting voor de moeilijk vervulbare vacatures. Aanvullende cursussen om de kennis te verbreden zijn hier dus gewenst. Daarnaast kan omscholing van werkzoekenden vanuit monteursfuncties waarvoor de arbeidsmarkt relatief ruim is soelaas bieden. Voor de functies in de handel, zoals confectie-arbeiders en winkeliers, blijkt vooral productkennis van groot belang te zijn. Branchegerichte opleidingstrajecten kunnen hierbij een effectief middel zijn. In de zorgberoepen, zoals de ziekenverzorgenden, speelt vooral het ontbreken van opleidingsplaatsen en de tijd en mogelijkheden om mensen intensief te begeleiden een rol. Het creëren van mogelijkheden om mensen ervaring op te laten doen is derhalve ook hier erg belangrijk. De werkgevers in de ICT-sector wijzen erop dat het omscholen van werkzoekenden tot programmeur geen afdoende middel is, aange zien ook in deze beroepsgroep er een grote behoefte bestaat aan ervaring.

In de zorgsector is bij de lagere beroepen verpleeghulpen en leerling-verpleegkundigen en hulpkrachten horeca en verzorging sprake van een ruime arbeidsmarkt. Het omscholen van werkzoekenden in deze beroepsgroepen tot ziekenverzorgende of apothekersassistente kan de knelpunten in deze beroepsgroepen doen verminderen. Voor de meeste beroepen moeten de omscholingsmogelijkheden echter vooral gezocht worden in het substantieel verhogen van het kwalificatieniveau van laaggeschoolden en het stimuleren van de arbeidsmarktparticipatie van goed gekwalificeerde jongeren en vrouwen.

Tabel 6.6 geeft een samenvattend overzicht van de gewenste aandachtspunten voor het scholingsbeleid in 1999, verbijzonderd naar de beroepsgroepen waarvoor knelpunten verwacht worden, de opleidingstypen waarop de scholing zich zou moeten richten, de aard van de gewenste bijscholing en de werkzoekenden die zijn opgeleid voor een verwant beroep die voor omscholing in aanmerking komen. 


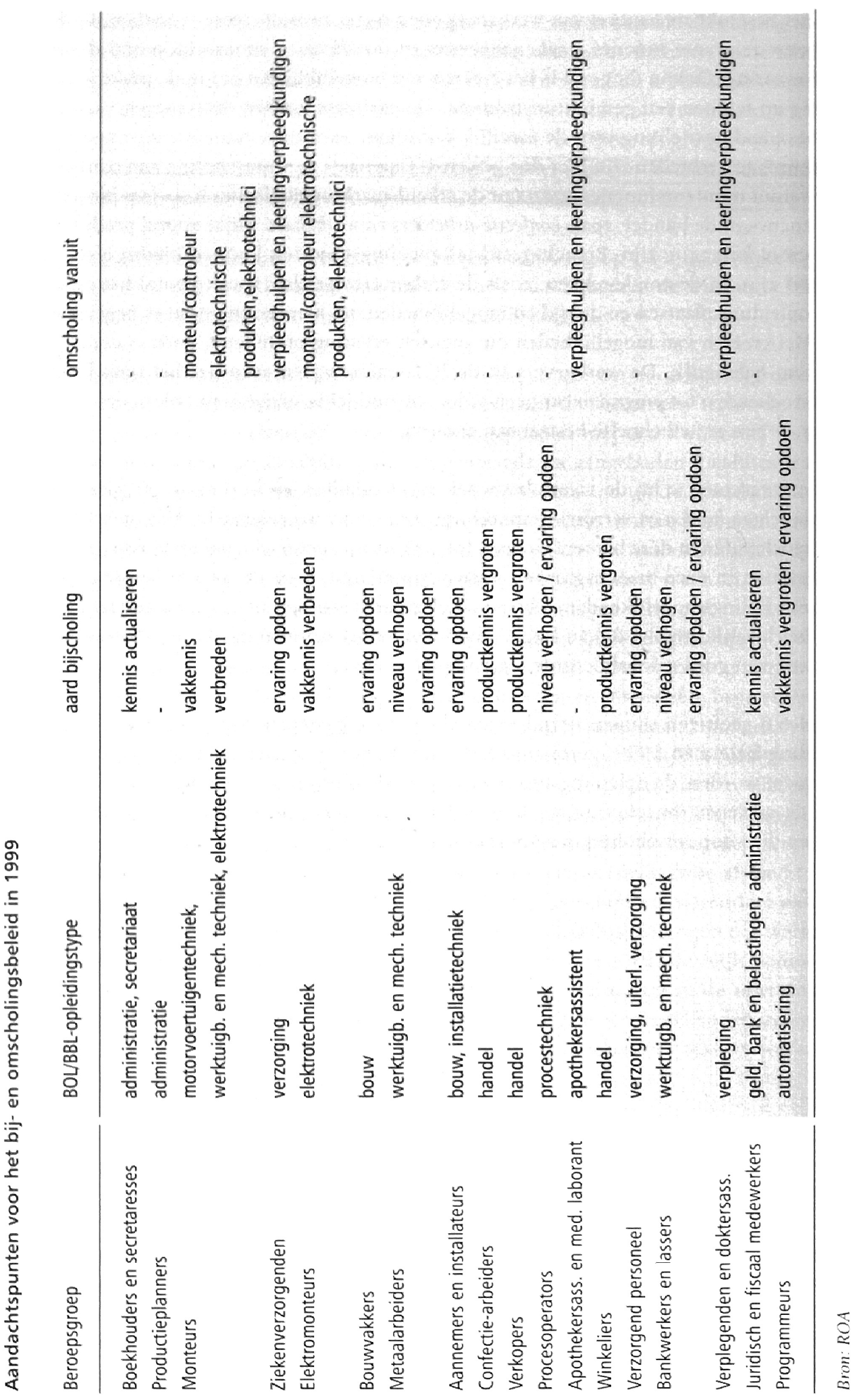




\section{De arbeidsmarktpositie van opleidingen}

\subsection{Inleiding}

In dit hoofdstuk staat de actuele en toekomstige arbeidsmarktpositie van de schoolverlaters in Limburg centraal. In paragraaf 7.2 komt de actuele arbeidsmarktpositie van schoolverlaters aan de orde. In dit hoofdstuk richten we ons met name op het MBO. Aan deze keuze liggen de volgende overwegingen ten grondslag. Ten eerste is dit opleidingsniveau in Limburg goed vertegenwoordigd. Een tweede reden is dat de arbeidsmarkt van hogere opleidingen - vanwege de grotere mobiliteit van de gediplomeerden - in mindere mate een regionaal karakter heeft. De laatste reden is dat het overgrote deel van de schoolverlaters van het MAVO/VBO niet direct de arbeidsmarkt op gaat, maar eerst voor een vervolgopleiding kiest.

In de eerste plaats wordt er een totaalbeeld voor het MBO gepresenteerd. Daarna zal er worden ingegaan op een aantal specifieke MBO-opleidingen ${ }^{38}$. Deze opleidingen zijn geselecteerd op basis van een drietal criteria: de betrouwbaarheid van de (regionale) informatie, het aandeel in de Limburgse werkgelegenheid en het belang van de opleidingen voor de drie speerpuntsectoren bouw, zorg en zakelijke dienstverlening. Op basis van deze criteria zijn de volgende opleidingen geselecteerd: bouw, werktuigbouw en mechanische technick, clektrotechniek, verpleging, administratie en handel. Voor deze opleidingen zal aan de hand van een zevental kenmerken een beeld van de arbeidsmarktpositie worden geschetst.

Paragraaf 7.3 zal meer gericht ingaan op de toekomstverwachtingen voor de schoolverlaters, die één van de genoemde opleidingen gevolgd hebben. Hierbij wordt, naast het arbeidsmarktperspectief, gekeken naar arbeidsmarktrisico's, zoals de uitwijkmogelijkheden en de conjunctuurgevoeligheid van de werkgelegenheid. Vervolgens wordt in paragraaf 7.4 nagegaan of een capaciteitsprobleem of een belangstellingsprobleem ten grondslag ligt aan een te kort schietend aanbod van schoolverlaters. Dit hoofdstuk wordt in paragraaf 7.5 afgesloten met de belangrijkste conclusies in de vorm van een aantal aandachtspunten voor het onderwijsbeleid.

\subsection{De arbeidsmarktpositie van schoolverlaters}

\section{Totaalbeeld voor het MBO}

Aansluitingsproblemen op de arbeidsmarkt kunnen zich op verschillende manieren manifesteren in de arbeidsmarktpositie van schoolverlaters. Het werkloosheidspercentage geeft een indicatie van de 'open discrepanties' tussen vraag en aanbod op de arbeidsmarkt. Naast deze open discrepanties kan er ook sprake zijn van 'verborgen discrepanties' bij diegenen die wel emplooi hebben gevonden. Daarvan is bijvoorbeeld sprake als schoolverlaters door een aanbodoverschot van arbeidskrachten met hun opleidingsachtergrond noodgedwongen werk accepteren beneden hun niveau of buiten de eigen vakrichting, slechter beloond

38 De cijfers in dit hoofdstuk hebben alleen betrekking op de beroepsopleidende lecrweg (BOI.). 
worden, vaker een tijdelijke in plaats van een vaste aanstelling krijgen, of vaker genoegen moeten nemen met deeltijdwerk, terwijl men liever een full-time betrekking zou willen hebben. Aan de hand van de zeven bovenstaande kenmerken kan de positie van schoolverlaters op de arbeidsmarkt worden gekenschetst.

In hoofdstuk 3 zagen we dat er sprake is van een verkrapping van de arbeidsmarkt. Voor de schoolverlaters betekent dit doorgaans dat zij zeer gewild zijn. Een analyse van de arbeidsmarktpositie van schoolverlaters geeft een goede indicatie van de betekenis van de verkrapping van de arbeidsmarkt voor de aansluiting tussen onderwijs en arbeidsmarkt ${ }^{39}$.

Voor een eerste indicatie van de arbeidsmarktpositie van schoolverlaters met een MBOopleiding, bekijken we het totaalbeeld. In tabel 7.1 wordt, aan de hand van bovengenoemde kenmerken, een overzicht gegeven van de arbeidsmarktpositie voor het MBO als geheel in 1996 en 1997. Hierbij wordt ook een vergelijking gemaakt met het landelijke beeld.

Tabel 7.1

Zeven kenmerken van de arbeidsmarktpositie van schoolverlaters van het MBO, Limburg en Nederland, 1996 en 1997

\begin{tabular}{|c|c|c|c|c|}
\hline Kenmerk & $\begin{array}{c}\text { Limburg } \\
1996\end{array}$ & $\begin{array}{c}\text { Nederland } \\
1996\end{array}$ & $\begin{array}{c}\text { Limburg } \\
1997\end{array}$ & $\begin{array}{c}\text { Nederland } \\
1997\end{array}$ \\
\hline$\%$ werkloos & 7 & 8 & 3 & 4 \\
\hline$\%$ intredewerkloosheid $>4$ maand & 14 & 12 & 9 & 10 \\
\hline$\%$ flexibele aanstelling & 43 & 45 & 39 & 36 \\
\hline$\%$ deeltijd & 30 & 28 & 22 & 24 \\
\hline$\%$ onderbenutting & 42 & 39 & 30 & 31 \\
\hline$\%$ buiten eigen vakrichting & 39 & 35 & 30 & 31 \\
\hline gemiddeld bruto maandloon (gulden) & 2.237 & 1.933 & 2.452 & 2.169 \\
\hline
\end{tabular}

Bron: $R O A$

De ontwikkeling in de tijd laat een eenduidig beeld zien. Alle indicatoren wijzen er op dat er in 1997 in Limburg sprake is van een sterk verbeterde arbeidsmarktpositie vergeleken met 1996. De (intrede)werkloosheid is afgenomen, er werken minder mensen part-time, het percentage flexibele contracten is afgenomen en de aansluiting tussen baan en opleiding is verbeterd. Daarnaast is het gemiddelde bruto maandloon gestegen met bijna $10 \%$. Dit beeld komt overeen met de geconstateerde verkrapping van de arbeidsmarkt, zoals deze werd waargenomen in hoofdstuk 3. De kengetallen voor geheel Nederland geven aan dat er ook landelijk duidelijk sprake is van een sterk verbeterde arbeidsmarktpositie van de schoolverlaters van het MBO. De verschillen tussen het Limburgse en het landelijke beeld zijn relatief gering. De arbeidsmarktpositie van de Limburgse schoolverlaters is iets beter dan landelijk. Met name het salarisniveau is in Limburg hoger. Dit weerspiegelt de iets

30 De gebruikte schoolverlatersinformatic is afkomstig uil de grootschalige schoolverlaters enquéte Registratie Uitstroom en Bestemming van Schoolverlaters (RUBS). 
grotere krapte op de Limburgse arbeidsmarkt, zoals ook blijkt uit het lagere werkloosheidspercentage onder de Limburgse schoolverlaters.

\section{Beeld per opleiding}

Tussen de verschillende opleidingstypen bestaan er echter duidelijke verschillen in de arbeidsmarktpositie van de schoolverlaters. Zoals gezegd, zal hier nader worden ingegaan op een zestal specifieke MBO-opleidingen. Daarbij staat de arbeidsmarktpositie in 1997 centraal. Achtereenvolgens zal hierbij worden ingegaan op de werkloosheid, de beloning van de schoolverlater, de aard van het dienstverband en de aansluiting tussen de gevolgde opleiding en de huidige functie.

\section{Werkloosheid}

Een belangrijk aspect van de arbeidsmarktpositie van de schoolverlaters van een bepaald opleidingstype is vanzelfsprekend de kans op het vinden van een baan. Tabel 7.2 geeft aan dat er bij 5 van de 6 opleidingen sprake is van een (zeer) lage werkloosheid. Een uitzondering vormt $B O L$ handel, met een werkloosheidspercentage van $8 \%$. BOL handel is ook de enige van de zes opleidingen met een werkloosheidspercentage dat in Limburg hoger is dan het landelijke percentage. Bij de andere opleidingen geeft de arbeidsmarktpositie van de Limburgse schoolverlaters een gunstiger beeld te zien dan de landelijke cijfers.

\section{Tabel 7.2}

Werkloosheidspercentage onder schoolverlaters per opleidingstype, Limburg en Nederland, 1997

\begin{tabular}{lllll} 
Opleidingstype & Limburg & typering & Nederland & typering \\
\hline BOL bouw & 0 & erg laag & 1 & erg laag \\
BOL werktuigb. en mech. techn. & 0 & erg laag & 3 & laag \\
BOL elektrotechniek & 2 & laag & 4 & gemiddeld \\
BOL verpleging & 0 & erg laag & 2 & laag \\
BOL administratie & 2 & laag & 5 & gemiddeld \\
BOL handel & 8 & hoog & 6 & gemiddeld \\
\hline
\end{tabular}

Bron: ROA

Het tweede werkloosheidskenmerk is de zogenaamde intredewerkloosheid, oftewel de lijd die een gediplomeerd schoolverlater werkloos is voor aanvang van zijn eerste baan. De intredewerkloosheid geeft een verdere indicatie van de moeilijkheden die schoolverlaters ondervinden bij het veroveren van een plek op de arbeidsmarkı. Tabel 7.3 geeft een overzicht van de percentages van de gediplomeerde schoolverlaters van de verschillende opleidingen met een intredewerkloosheid van vier maanden of meer. De tabel geef een idenlick beeld te zien als tabel 7.2. Het percentage schoolverlaters dat langer dan vier maanden werkloos is, is in Limburg, met uitzondering van BOL handel, lager dan landelijk. Als de werkloosheidscijfers van tabel 7.3 en 7.2 met elkaar worden vergeleken kom het beeld natr voren dat bij de meeste opleidingen (vrijwel) alle schoolverlaters na enige tijd werk vinden, 
maar dit betekent nog niet dat alle schoolverlaters direct na het verlaten van de schoolbanken een baan hebben.

Tabel 7.3

Percentage schoolverlaters met intredewerkloosheid van 4 maand of langer per opleidingstype, Limburg en Nederland, 1997

\begin{tabular}{lccccc} 
& Limburg & typering & Nederland & typering \\
\cline { 2 - 6 } Opleidingstype & 8 & gemiddeld & 11 & gemiddeld \\
BOL bouw & 2 & erg laag & 4 & laag \\
BOL werktuigb. en mech. techn. & 3 & erg laag & 4 & laag \\
BOL elektrotechniek & 2 & erg laag & 6 & laag \\
BOL verpleging & 11 & gemiddeld & 15 & hoog \\
BOL administratie & 15 & hoog & 11 & gemiddeld \\
BOL handel & & & & \\
\hline
\end{tabular}

Bron: $R O A$

\section{Beloning}

De beloning geeft een indruk van het productieve vermogen van de schoolverlaters. Bovendien is de beloning een indicator voor de schaarste aan (nieuwe) werknemers met de desbetreffende opleidingsachtergrond. Tabel 7.4 geeft aan dat de werkende schoolverlaters in Limburg gemiddeld genomen meer verdienen dan landelijk als ze de opleiding BOL bouw, $B O L$ werktuigbouw en mechanische techniek of BOL administratie hebben gevolgd. De schoolverlaters van $B O L$ verpleging, BOL elektrotechniek en $B O L$ handel verdienen in Limburg gemiddeld genomen minder dan landelijk. Met name voor BOL verpleging is het verschil in bruto maandsalaris aanzienlijk. Dit verschil. kan waarschijnlijk voor een deel worden toegeschreven aan het feit dat de schoolverlaters van $B O L$ verpleging in Limburg veel meer op flexibele contractbasis werkzaam zijn (zie tabel 7.5).

Tabel 7.4

Gemiddeld bruto maandsalaris in guldens voor werkende schoolverlaters per opleidingstype, Limburg en Nederland, 1997

\begin{tabular}{|c|c|c|c|c|}
\hline Opleidingstype & Limburg & typering & Nederland & typering \\
\hline BOL bouw & 2.884 & hoog & 2.622 & gemiddeld \\
\hline BOL werktuigb. en mech. techn. & 2.802 & hoog & 2.666 & hoog \\
\hline BOL elektrotechniek & 2.420 & gemiddeld & 2.602 & gemiddeld \\
\hline BOL verpleging & 2.048 & erg laag & 2.448 & gemiddeld \\
\hline BOL administratie & 2.332 & gemiddeld & 2.219 & laag \\
\hline BOL handel & 1.907 & erg laag & 2.038 & erg laag \\
\hline
\end{tabular}

Bron: ROA 
Uit tabel 7.1 bleek dat de MBO-schoolverlater, gemiddeld genomen, ruim 2.450 gulden verdient. Tabel 7.4 laat zien dat vier van de zes gekozen opleidingen in Limburg qua salariëring onder dit gemiddelde liggen. Opvallend genoeg is het landelijke beeld omgekeerd, namelijk slechts één opleiding - BOL handel - ligt beneden het landelijk gemiddelde van fl. $2.169,-$. Bij de meeste opleidingen weerspiegelen de salarisverschillen tussen de Limburgse schoolverlaters en het landelijk gemiddelde de verschillen in het werkloosheidspercentage. Alleen bij de opleidingen BOL elektrotechniek en BOL verpleging is het beloningsverschil niet marktconform. Bij deze opleidingen gaat een grotere krapte op de Limburgse arbeidsmarkt gepaard met een lager beloningsniveau dan landelijk.

\section{Aard dienstverband}

De aard van het dienstverband van de werkende schoolverlater hangt doorgaans ook samen met de arbeidsmarktpositie van de gevolgde opleiding. Bij een verkrapping van de arbeidsmarkt zullen werkgevers trachten hun werknemers zoveel mogelijk aan zich te binden. Verkrapping van de arbeidsmarkt remt daardoor de flexibilisering van de arbeidsmarkt af. Een laag percentage schoolverlaters met een flexibele aanstelling kan dus duiden op een zekere krapte bij de desbetreffende opleiding. Tabel 7.5 toont aan dat er voor vier van de zes opleidingen sprake is van een laag percentage schoolverlaters met een flexibele aanstelling. Alleen de opleidingen BOL verpleging en BOL administratie vallen uit de toon. Gezien de krapte op de arbeidsmarkt lijkt het hoge percentage schoolverlaters van deze opleidingen met een flexibel dienstverband niet marktconform. Bovendien zal het de knelpunten in de personeelsvoorziening waarschijnlijk vergroten. Voor BOL administratie geldt dat het hoge percentage flex-werk veelal voortkomt uit uitzendbanen, bijvoorbeeld secretaresses en lager administratief personeel.

\section{Tabel 7.5}

Percentage werkende schoolverlaters met een flexibele aanstelling per opleidingstype, Limburg en Nederland, 1997

\begin{tabular}{lccccc} 
Opleidingstype & Limburg & typering & Nederland & typering \\
\cline { 3 - 5 } BOL bouw & 24 & laag & 23 & laag \\
BOL werktuigb. en mech. techn. & 31 & laag & 34 & laag \\
BOL elektrotechniek & 31 & laag & 25 & laag \\
BOL verpleging & 52 & hoog & 37 & gemiddeld \\
BOL administratie & 53 & hoog & 45 & gemiddeld \\
BOL handel & 32 & laag & 35 & laag
\end{tabular}

Brom: ROA

Een tweede aspect van de flexibilisering is de mate waarin er in deeltijd wordt gewerkt. Hel percentage in deeltijd werkende schoolverlaters is weergegeven in tabel 7.6. Er kom geen eenduidig beeld uit naar voren. Limburg heeft soms een hoger, soms een lager percentage deeltijders, maar over het algemeen is het vergelijkbaar met de landelijke gegevens. De mate waarin in deeltijd wordt gewerkt hangt vanzelfsprekend ook samen met de wens van de schoolverlaters zelf om in deeltijd te werken. Zo is het hoge percentage deeltijders bij BOI. 
verpleging toe te schrijven aan het hoge percentage vrouwen onder de schoolverlaters van deze opleiding. Ook bij BOL handel zien we een redelijk hoog percentage deeltijders. Deze groep schoolverlaters, wederom grotendeels vrouwen, is veelal als winkelpersoneel werkzaam. Ten slotte valt het lage percentage bij de technische opleidingen op, met als meest sprekende voorbeeld BOL elektrotechniek $(0 \%)$.

\section{Tabel 7.6}

Percentage in deeltijd werkende schoolverlaters per opleidingstype, Limburg en Nederland, 1997

\begin{tabular}{lccccc} 
Opleidingstype & & Limburg & typering & Nederland & typering \\
\cline { 2 - 6 } & & 10 & laag & 13 & gemiddeld \\
BOL bouw & 5 & erg laag & 4 & erg laag \\
BOL werktuigb. en mech. techn. & - & erg laag & 4 & erg laag \\
BOL elektrotechniek & 43 & hoog & 49 & hoog \\
BOL verpleging & 14 & gemiddeld & 15 & gemiddeld \\
BOL administratie & 29 & gemiddeld & 25 & gemiddeld \\
BOL handel & & & & & \\
\hline
\end{tabular}

Bron: ROA

\section{Aansluiting tussen baan en opleiding}

De aansluiting tussen beroep en opleiding kent twee dimensies: de aansluiting tussen de inhoud van de baan en de gevolgde opleidingsrichting en de benutting van het verworven kwalificatie-niveau. Hoe kleiner het percentage schoolverlaters dat beneden het gevolgde opleidingsniveau werkzaam is (onderbenutting) of hoe kleiner het percentage schoolverlaters dat buiten de gevolgde vakrichting werkzaam is, des te beter is de aansluiting tussen opleiding en baan. Aangenomen mag worden dat een verkrapping op de arbeidsmarkt leidt tot een verbetering van de aansluiting tussen de gevolgde opleiding en de baan die men heeft. Men is dan immers niet gedwongen uit te wijken naar een baan op een lager niveau of in een ander beroepsveld ${ }^{\text {to }}$. De tabellen 7.7 en 7.8 geven de percentages schoolverlaters waarbij er sprake is van onderbenutting en werken buiten de eigen vakrichting. De verschillen tussen Limburg en het landelijke beeld zijn over het algemeen gering. Wat onderbenutting betreft is het verschil tussen Limburg en Nederland als geheel het grootst voor BOL verpleging. De Limburgse schoolverlaters zijn, vergeleken met de rest van Nederland, vaker op een te laag niveau werkzaam. Gezien de krapte op dit arbeidsmarktsegment is dat verwonderlijk. Uit beide tabellen komt $B O L$ handel duidelijk als minst positieve uit de bus. Zowel voor Limburg alsook landelijk, laat de ansluiting van deze specifieke opleiding duidelijk te wensen over. Dit weerspiegelt de minder gunstige arbeidsmarktpositie van de schoolverlaters van deze opleiding.

to Een verkmping van de arbeidsmarkt kan overigens ook weer de aansluiting tussen opleiding en werk verslechteren, wanneer werkgevers gedwongen zijn schoolverlaters op een, in vergelijking tot hun opleiding, te hoog functieniveau in te zetten. 
Tabel 7.7

Percentage werkende schoolverlaters dat beneden het opleidingsniveau werkzaam is (onderbenutting) per opleidingstype, Limburg en Nederland, 1997

\begin{tabular}{lllll} 
Opleidingstype & Limburg & typering & Nederland & typering \\
\cline { 2 - 5 } BOL bouw & 27 & gemiddeld & 22 & gemiddeld \\
BOL werktuigb. en mech, techn. & 29 & gemiddeld & 30 & gemiddeld \\
BOL elektrotechniek & 24 & gemiddeld & 22 & gemiddeld \\
BOL verpleging & 39 & hoog & 31 & gemiddeld \\
BOL administratie & 29 & gemiddeld & 29 & gemiddeld \\
BOL handel & 43 & hoog & 48 & erg hoog \\
\end{tabular}

Bron: $R O A$

Tabel 7.8

Percentage werkende schoolverlaters dat buiten de eigen vakrichting werkzaam is per opleidingstype, Limburg en Nederland, 1997

\begin{tabular}{lllll} 
Opleidingstype & Limburg & typering & Nederland & typering \\
\cline { 2 - 5 } BOL bouw & 23 & gemiddeld & 26 & gemiddeld \\
BOL werktuigb. en mech. techn. & 20 & laag & 22 & gemiddeld \\
BOL elektrotechniek & 19 & laag & 14 & laag \\
BOL verpleging & 24 & gemiddeld & 24 & gemiddeld \\
BOL administratie & 39 & gemiddeld & 39 & gemiddeld \\
BOL handel & 54 & erg hoog & 52 & hoog \\
\end{tabular}

Bron: $R O A$

\subsection{Kansen op de arbeidsmarkt: een typologie}

\section{Inleiding}

Voor de vraagzijde van de arbeidsmark1 - de werkgevers - vormen schoolverlaters een belangrijke groep waaruit nieuwe arbeidskrachten worden gerekruteerd. Paragraaf 7.2 hecft laten zien dat voor schoolverlaters de initiële opleidingskeuze voor een groot decl bepalend is voor hun arbeidsmarktpositie. Ook voor het verdere loopbaanperspectief speelt de initiële opleidingsachtergrond een belangrijke rol.

In De Limburgse arbeidsmarkt 1997-2002 is aandacht geschonken aan het toekomstig arbeidsmarktperspectief van de verschillende opleidingen op de Limburgse arbeidsmarkı op de middellange termijn. Deze toekomstige perspectieven zullen hier in een breder kader worden geplaatst. Daarbij staat de rol van het initiële onderwijs centraal. Aangezien schoolverlaters van nieuwe of vernieuwde opleidingen pas na een aantal jaren zullen instromen op de arbeidsmarkt, zullen investeringen in het initiële onderwijs pas na een aantal jaren 
effect hebben op de arbeidsmarktinstroom. Daarom wordt hier de nadruk gelegd op de perspectieven op de middellange termijn.

Vanuit het oogpunt van de zogenaamde macrodoelmatigheid van het onderwijs is het wenselijk de instroom in opleidingstypen met goede of zeer goede arbeidsmarktperspectieven te bevorderen. Het zonder meer vergroten van het onderwijsaanbod zal echter niet altijd de gewenste effecten sorteren. Een vergroting van de opleidingscapaciteit garandeert immers niet dat deze capaciteit ook benut zal worden. Een betere geografische spreiding of de introductie van een opleidingsvariant die op dat moment nog niet wordt aangeboden, zal doorgaans wel de instroom voor het desbetreffende opleidingstype verhogen, doordat mobiliteitsdrempels worden weggenomen of beter ingespeeld kan worden op de interesse of capaciteiten van bepaalde groepen leerlingen.

Een vraag die zich voordoet bij een dergelijke uitbreiding van het onderwijsaanbod is echter welke leerlingen hiermee worden aangetrokken. Als een verhoogde geografische spreiding er alleen toe leidt dat leerlingen dezelfde opleiding minder ver van huis kunnen volgen, of als de extra belangstelling voor een nieuwe opleiding met goede perspectieven leerlingen trekt die anders een opleiding met zeer goede perspectieven hadden gekozen, is de 'macrodoelmatigheid' van de nieuwe opleiding ondanks de gunstige arbeidsmarktperspectieven voor de schoolverlaters beperkt.

Nieuw aanbod van opleidingen zal daarom met name zin hebben wanneer er leerlingen worden aangetrokken die anders een opleiding zouden kiezen met duidelijk slechtere perspectieven. Zo kan de keuze voor opleidingen met slechte perspectieven het gevolg zijn van de reisafstand naar een school waar een meer perspectiefrijke opleiding gevolgd zou kunnen worden die eveneens aansluit op de belangstelling en de capaciteiten van de desbetreffende leerling. Ook kan de oorzak voor de keuze voor een opleiding met slechte perspectieven liggen in de capaciteiten en interesses van de leerlingen. Een nieuwe opleiding die, door het aanbieden van een leerweg voor leerlingen met beperkte capaciteiten, deze leerlingen toch adequaat opleidt in een richting met goede perspectieven, kan in dat opzicht een zeer waardevolle aanvulling zijn op het bestaande opleidingsaanbod. Op vergelijkbare wijze kan een nieuwe opleiding in een richting met goede perspectieven, die door een andere opzet van de opleiding meer belangstelling van een bepaalde groep leerlingen weet te wekken, een verhoogde instroom bewerkstelligen. Een voorbeeld daarvan zouden technische opleidingen met (zeer) goede arbeidsmarktperspectieven kunnen zijn die meer meisjes weten aan te trekken door het onderwijsprogramma aan te passen. Vanuit deze optiek is het overigens niet in de eerste plaats van belang dat er sprake is van een zeer goed arbeidsmarktperspectief, maar wordı de aansluiting onderwijs-arbeidsmarkt met name verbeterd als leerlingen dic aanvankelijk zouden kiezen voor een richting met minder goede perspectieven nu kiezen voor een opleiding met een beter perspectief.

De omvang van de verwachte instroom op de arbeidsmarkt vormt een indicatie voor de mogelijkheden die een capaciteitsvergroting biedt. Zoals hierboven reeds werd opgemerkt, dient cen capaciteitsvergroting ter vergroting van de macrodoelmatigheid gepaard te gaan met het aantrekken van de 'juiste' doelgroep. Dit kan betekenen dat een andere opleiding gekozen wordt of dat wordt doorgestroomd naar een meer perspectiefrijke opleiding. Bovendien dient er voldoende 'infrastructuur' in de regio aanwezig te zijn om de toegeno- 
men leerlingenstroom een adequate voorbereiding op de arbeidsmarkt te kunnen bieden. Hierbij gaat het niet alleen om het onderwijs zelf, maar bijvoorbeeld ook om het aantal leerplaatsen bij bedrijven.

Wanneer de verwachte instroom reeds relatief hoog is, vindt het goede perspectief vooral zijn oorsprong in de grote vraag naar nieuwkomers met het betreffende opleidingstype. De opleiding is dan reeds relatief populair in verhouding tot de 'omvang' van de markt voor deze opleiding in Limburg. Dit impliceert dat het omzetten van een eventuele capaciteitsvergroting in een daadwerkelijke vergroting van de instroom aanzienlijke inspanningen zal vragen, zoals het verder vergroten van het aantal leerplaatsen bij bedrijven en het aanboren van geheel nieuwe groepen leerlingen. Wanneer daarentegen de verwachte instroom relatief klein is, ligt vooral de geringe instroom aan het goede perspectief ten grondslag. In dat geval zal het omzetten van een eventuele capaciteitsvergroting in een daadwerkelijke vergroting van de instroom waarschijnlijker eenvoudiger te realiseren zijn. Het marktaandeel van deze opleiding is dan waarschijnlijk laag. Door bijvoorbeeld de doorstroom uit de lagere opleidingen - met een slechter perspectief - te bevorderen kan het marktaandeel vergroot worden. Ook het realiseren van de gewenste infrastructuur in de regio zal waarschijnlijk eenvoudiger zijn, hoewel er in specifieke segmenten van de arbeidsmarkı natuurlijk specifieke problemen kunnen voorkomen welke een verdere capaciteitsvergroting kunnen belemmeren.

Naast het arbeidsmarktperspectief, dat gebaseerd is op de verwachte ontwikkelingen in vraag en aanbod, kan het onderwijsbeleid ook de structurele positie van opleidingen als richtlijn nemen. Een tweetal risico-indicatoren is op dit punt van belang: de conjunctuurgevoeligheid van de werkgelegenheid en de uitwijk mogelijkheden naar verschillende beroepsgroepen. Zo zijn er bepaalde opleidingen die een hoge mate van conjunctuurgevoeligheid combineren met beperkte uitwijkmogelijkheden. Veranderingen in het curriculum, waardoor de opleiding wordt verbreed en waardoor toegang wordt verkregen tot een breder beroependomein, kunnen deze kwetsbaarheid verminderen. Omgekeerd kunnen ontwikkelingen aan de vraagkant van de arbeidsmarkt leiden tot een behoefte aan personeel met specifieke vaardigheden. Hierdoor kan het wenselijk zijn een meer specialistische opleiding te starten. Hierbij dient echter wel overwogen te worden in hoeverre de vraag naar deze vakspecialisten stabiel is, omdat de voordelen van het specialisme op moeten wegen tegen de risico's die met een dergelijke specialisatie worden gelopen.

In deze paragraaf wordt een typologie gegeven van de arbeidsmarkikansen voor de schoolverlaters van de onderscheiden opleidingstypen op VBO- en MBO-niveau op de Limburgse arbeidsmarkt aan de hand van het toekomstig arbeidsmarktperspectiel, de conjunctuurgevoeligheid van de werkgelegenheid en de uitwijkmogelijkheden op de arbeidsmarkt". Deze typologie is reeds in De Limburgse arbeidsmarkt 1997-2002 ontwikkeld. In paragraal 7.4 wordt aan de hand van een analyse van de omvang van de verwachte instroom op de arbeidsmarkt een indicatie gegeven van de mogelijkheden die cen capaciteitsvergroting van vooral de opleidingen met een structureel goed arbeidsmarktperspectief biedt om de macro-

+1 Vooralsnog zijn, in het licht van de betrouwbaarheid en de beschikbaarheid van de vereiste regionale data, de indicatoren voor de conjunctuurgevoeligheid van de werkgelegenheid en de uilwijkmogelijkheden gebaseerd op landelijke cijfers. 
doelmatigheid van het onderwijs te verbeteren. Dit hoofdstuk wordt in paragraaf 7.5 afgesloten met een aantal conclusies in de vorm van aandachtspunten voor het onderwijsbeleid.

\section{Het toekomstig arbeidsmarktperspectief}

Aan de hand van de verwachte ontwikkelingen aan de vraag- en de aanbodzijde van de arbeidsmarkt is in De Limburgse arbeidsmarkt 1997-2002 een indicatie gegeven van de te verwachten toekomstige arbeidsmarktperspectieven op de middellange termijn voor nieuwkomers op de arbeidsmarkt, verbijzonderd naar opleidingstype. Dit arbeidsmarktperspectief op de middellange termijn (d.w.z. tot 2002) van een bepaalde opleiding geeft aan wat - op basis van de verwachte ontwikkelingen aan de vraag- en aanbodzijde van de arbeidsmarkt gedurende de komende vijf jaar - de mogelijkheden zijn voor nieuwkomers om een baan te vinden die op grond van de opleidingsachtergrond als passend kan worden beschouwd.

De voor de periode 1997-2002 verwachte relatief gunstige arbeidsmarktontwikkelingen in Limburg zullen ertoe leiden dat voor een groot aantal opleidingstypen goede tot zeer goede arbeidsmarktperspectieven worden verwacht, met name op MBO-niveau. Op de Limburgse arbeidsmarkt zullen de aanbodtekorten naar verwachting sterker merkbaar zijn dan landelijk, waardoor de perspectieven voor de Limburgse nieuwkomers gemiddeld genomen beter zijn dan voor de nieuwkomers in de rest van het land. Dit verschil met het landelijke beeld valt met name toe te schrijven aan demografische factoren. Met name de vervangingsvraag zal naar verwachting in Limburg aanzienlijk hoger zijn dan landelijk, als gevolg van de snelle vergrijzing van de Limburgse beroepsbevolking.

\section{De conjunctuurgevoeligheid}

Het arbeidsmarktperspectief wordt voor een belangrijk deel bepaald door de verwachte economische ontwikkeling. Een goed perspectief kan daarbij het gevolg zijn van een structureel sterke positie van het betreffende opleidingstype op de arbeidsmarkt. Het kan echter ook voor een belangrijk deel conjunctureel van aard zijn. Zo kan een relatief gunstige conjuncturele ontwikkeling een structureel zwakke positie tijdelijk compenseren. Wanneer de keuze voor een conjunctuurgevoelig opleidingstype gebaseerd is op een goed perspectief, bestaat het risico dat de kansen op de arbeidsmarkt op het moment dat het diploma behaald wordt slecht zijn, omdat de economische situatie door een conjuncturele dip plotseling is verslechterd. Bovendien is er in dat geval sprake van een onzekere werkgelegenheidssituatic op de langere termijn, vanwege de grotere kans op toekomstig baanverlies als er op een gegeven moment sprake is van een laagconjunctuur. De conjunctuurgevoeligheid van de werkgelegenheid is derhalve een risico-indicator, waarmee een belangrijk facet wordt belicht van de structurele arbeidsmarktpositie van een opleidingstype.

\section{De uitwijkmogelijkheden}

De risico's op de arbeidsmarkt beperken zich niet tot de conjuncturele fluctuaties in de werkgelegenheid. Ook de mate waarin schoolverlaters afhankelijk zijn van de werkgelegenheidsperspectieven in een beperkt aantal beroepsgroepen is een belangrijke risicofactor. Dit risico is vooral groot bij opleidingen die specifiek gericht zijn op functies in een 
bepaalde vakdeelmarkt. Degenen die daarentegen een opleiding hebben gevolgd waarmee men in diverse beroepsgroepen emplooi kan vinden, kunnen, wanneer het werkgelegenheidsperspectief in een bepaalde beroepsgroep minder gunstig is, betrekkelijk gemakkelijk uitwijken naar beroepen waarvoor de werkgelegenheidsontwikkeling gunstiger is. Er is als het ware sprake van een zekere risico-spreiding. Bovendien zijn degenen die voor deze opleidingen hebben gekozen meer flexibel op de arbeidsmarkt, wanneer de beroepsperspectieven die aanvankelijk aantrekkelijk leken hun aantrekkingskracht verliezen, doordat men tijdens de studie- of arbeidsloopbaan meer inzicht verkrijgt in de persoonlijke capaciteiten en voorkeuren die men heeft. In dat geval mag ook verwacht worden dat men minder snel voortijdig de opleiding zal verlaten, dan wanneer een opleiding gevolgd wordı die specifiek voor een bepaald beroep opleidt.

Het volgen van een brede opleiding is overigens niet in alle gevallen positief. Wanneer er sprake is van veel uitwijkmogelijkheden impliceert dit immers ook dat de schoolverlaters meer concurrentie ondervinden van andere opleidingstypen. Bovendien kan een verbreding van de opleiding ten koste gaan van de specialisatie, waardoor de productiviteit, c.q. de directe inzetbaarheid van de schoolverlaters geringer wordt. Wanneer de concurrentieslag met andere opleidingen daardoor verloren wordt, kan dat in sommige gevallen zelfs betekenen dat de schoolverlaters in een breed scala van onaantrekkelijke beroepen met slechte arbeidsvoorwaarden terechtkomen (de zogenaamde secundaire arbeidsmarkt).

\section{Kansen op de arbeidsmarkt: een typologie}

Terwijl het toekomstig arbeidsmarktperspectief een indicatie geeft van de kansen voor nieuwkomers op de arbeidsmarkt op een passende baan gezien hun opleidingsachtergrond, geven de conjunctuurgevoeligheid en de uitwijkmogelijkheden aan in hoeverre de keuze voor een opleiding gepaard gaat met een arbeidsmarktrisico dat de arbeidsmarktkansen zou kunnen ondermijnen ${ }^{+2}$.

Wanneer een goed arbeidsmarktperspectiel gepaard gaat met een laag arbeidsmarktrisico dat wil zeggen een lage tot gemiddelde conjunctuurgevoeligheid van de werkgelegenheid en gemiddelde tot grote uitwijkmogelijkheden - dan geeft het betreffende opleidingstype schoolverlaters een structureel sterke positie op de arbeidsmarkt. Op de Limburgse arbeidsmarkt geldt dit met name voor de volgende opleidingstypen:

- BOL/BBL landbouw en veeteelt;

- BOL/BBL milieu en groene ruimte;

- BOL/BBL brood en banket;

- BOL/BBL levensmiddelentechniek/vleesverwerking;

- BOL/BBL horeca;

- BOL/BBL administratie;

- BOL/BBL handel;

- BOLBBL bedrijfskunde;

+2 Een volledig overzicht van het arbeidsmarktperspectief, de conjunctuurgevoeligheid en de uitwijkmoge lijkheden naar opleidingstype, waarop deze paragraal is gebaseerd, word gegeven in de tabellen $4.8 \mathrm{en}$ 4.9 van de Statistische Bijlage. 
- BOL/BBL geld, bank en belastingen;

- BOLBBL automatisering.

Deze opleidingstypen zijn grofweg te verdelen in twee groepen. De eerste groep betreft de 'groene' opleidingen landbouw en veeteelt en milieu en groene ruimte en de op de voedingsmiddelbranche gerichte opleidingen brood en banket en levensmiddelentechniek. Bij deze opleidingen gaat het goede perspectief met name gepaard met een lage conjunctuurgevoeligheid. De kansen op werk voor nieuwkomers zijn relatief ongevoelig voor conjuncturele fluctuaties. Bovendien zal later in de loopbaan, wanneer de conjunctuur eventueel verslechtert, de kans relatief klein zijn dat men zijn baan verliest. De tweede groep wordt gevormd door de economische opleidingen administratie, handel, automatisering en geld, bank en belastingen. Deze opleidingstypen worden naast de goede arbeidsmarktperspectieven op middellange termijn met name gekenmerkt door een brede inzetbaarheid op de arbeidsmarkt.

Wanneer daarentegen een goed arbeidsmarktperspectief gepaard gaat met een hoog risico een gemiddeld tot (erg) hoge conjunctuurgevoeligheid en gemiddelde tot (erg) lage uitwijkmogelijkheden - dan is weliswaar, op grond van de verwachte arbeidsmarktontwikkelingen, de kans op een passende baan voor de schoolverlaters met een dergelijke opleidingsachtergrond groot, maar kan een verslechtering van de arbeidsmarktsituatie een sterk negatief effect hebben op de arbeidsmarktpositie. Dit geldt met name voor de volgende opleidingstypen:

- VBO bouwtechniek;

- VBO installatietechniek;

- VBO fijnmechanische techniek;

- VBO elektrotechniek;

- VBO brood en banket;

- VBO vervoer;

- VBO beveiliging;

- alle technische opleidingen op MBO-niveau, met uitzondering van de op de voedingsmiddelbranche gerichte opleidingen brood en banket en levensmiddelen-technologie;

- BOL/BBL secretariaal;

- BOL verzekeringswezen;

- BOL openbare orde en veiligheid.

Deze categorie bestaat derhalve voor een groot deel uit technische opleidingen. De arbeidsmarktkansen voor de schoolverlaters van de technische opleidingen worden voor een aanzienlijk deel bepaald door de werkgelegenheidsontwikkelingen in de conjunctuurgevoclige industriële bedrijfssectoren en de bouw. Het goede arbeidsmarktperspectief is dus voor een deel conjunctureel van aard. Een (onvoorziene) conjuncturele achteruitgang kan het perspectief aanzienlijk verslechteren. Ook het arbeidsmarktrisico voor de BOL-opleidingen secretariaat en verzekeringswezen en de beveiligingsopleidingen is relatief groot. Voor deze opleidingstypen vormt met name de beperkte inzetbaarheid buiten het eigen beroependomein een risicoverhogende factor.

Een bijzondere positie nemen de vërzorgende en medische opleidingen op MBO-niveau in. Het arbeidsmarktperspectief voor deze opleidingstypen is goed tot zeer goed. Bovendien is de conjunctuurgevoeligheid van de werkgelegenheid laag. Twee factoren maken de arbeidsmarkipositie van de schoolverlaters van deze opleidingstypen echter kwetsbaar. In de eerste 
plaats is de omvang van de vraag in aanzienlijke mate afhankelijk van het overheidsbeleid. In de tweede plaats zijn de arbeidskrachten met een medische of verzorgende opleidingsachtergrond beperkt inzetbaar; de uitwijkmogelijkheden op de arbeidsmarkt zijn over het algemeen gering.

Wanneer een slecht arbeidsmarktperspectief gepaard gaat met een gering arbeidsmarktrisico, dan is de kans op een passende baan naar verwachting weliswaar klein, maar biedt de brede inzetbaarheid misschien mogelijkheden om elders op de arbeidsmarkt een plek te vinden. Dit geldt met name voor de volgende opleidingstypen:

- MAVO;

- VBO horeca en levensmiddelentechniek;

- VBO administratie, handel en textiel;

- VBO verzorging;

- HAVO/NWO;

- BOL sociaal-cultureel.

Gezien het lage opleidingsniveau is deze brede inzetbaarheid voor de MAVO'ers en de genoemde VBO-opleidingen, zoals reeds eerder werd aangegeven, een betrekkelijk begrip. Vaak zullen schoolverlaters terechtkomen in functies op de 'secundaire arbeidsmarkt'. Dit secundaire arbeidsmarktsegment kent met name banen die een onaantrekkelijk karakter hebben als gevolg van bijvoorbeeld zware arbeidsomstandigheden en tijdelijke contracten.

Opleidingstypen waarvoor het arbeidsmarktperspectief naar verwachting slecht zal zijn en waarvoor bovendien de risico-indicatoren wijzen op een grote kwetsbaarheid, kennen een structureel zwakke positie op de arbeidsmarkt. De kans op een passende baan is klein en bovendien is de concurrentiepositie op andere segmenten van de arbeidsmarkt zo zwak dat er nauwelijks alternatieve banen te vinden zijn. Dit geldt voor de volgende opleidingstypen:

- VBO vervoer;

- VBO motorvoertuigentechniek;

- VBO grafische techniek;

- BOL/BBL toerisme en recreatie.

Met name de hoge conjunctuurgevoeligheid makt de VBO-opleidingen bouwtechnick, motorvoertuigentechniek en grafische techniek extra kwetsbaar. Schoolverlaters van de opleiding BOLBBL toerisme en recreatie zijn binnen het $\mathrm{MBO}$ een kwetsbare groep vanwege de slechte arbeidsmarktperspectieven en de beperkte inzetbaarheid op de arbeidsmarkı.

\subsection{De onderwijscapaciteit in Limburg: de verwachte arbeidsmarktinstroom}

Zoals in paragraaf 7.3 reeds werd opgemerkt, dient een capaciteitsvergroting ter vergroting van de macrodoelmatigheid van het onderwijs gepaard te gaan met het aantrekken van de 'juiste' doelgroep zoals hierboven geschtetst. Bovendien dient er voldoende 'infrastructuur' in de regio aanwezig te zijn om de toegenomen leerlingenstroom een adequate voorbereiding op de arbeidsmarkı te kunnen bieden.

In tabel 7.9 wordt, voor de opleidingstypen warvan hei arbeidsmarktperspectief als structureel goed is getypeerd, een overzicht gegeven van de verwachte arbeidsmarktinstroom tot het jaar 2002. 
Tabel 7.9

Verwachte instroom 1997- 2002 voor de opleidingstypen met een structureel goed perspectief, Limburg (als percentage van de werkgelegenheid)

Opleidingstype

BOLBBL milieu en groene ruimte

$B O L / B B L$ landbouw en veeteelt

$\mathrm{BOL} / \mathrm{BBL}$ horeca

BOL/BBL handel

BOL/BBL administratie

$\mathrm{BOL} / \mathrm{BBL}$ brood en banket

$\mathrm{BOL} / \mathrm{BBL}$ levensmiddelentechniek/vleesverwerking

BOL/BBL bedrijfskunde

$\mathrm{BOL} / \mathrm{BBL}$ geld, bank en belastingen

BOL/BBL automatisering instroom typering

\begin{tabular}{cl}
\hline 28 & hoog \\
19 & gemiddeld \\
12 & gemiddeld \\
11 & gemiddeld \\
9 & laag \\
& laag \\
. & laag \\
& erg laag \\
& erg laag \\
& erg laag \\
\hline
\end{tabular}

Bron: ROA

De tabel laat zien dat met name voor de 'groene' opleidingen $B O L B B L$ landbouw en veeteelt en BOL/BBL milieu en groene ruimte een gemiddeld tot hoge instroom verwacht wordt. Deze opleidingen zijn relatief populair in verhouding tot de 'omvang' van de markt voor deze opleidingen in Limburg. Dit betekent dat het vergroten van de instroom door een capaciteitsvergroting naar verwachting een aanzienlijke inspanning zal vergen. Met name voor de opleidingen BOL/BBL bedrijsskunde, BOL/BBL geld, bank en belastingen en BOL/BBL automatisering zal de instroom relatief gering zijn. Dit betekent dat een capaciteitsvergroting, het aantrekken van nieuwe groepen leerlingen en het ontwikkelen van de benodigde 'infrastructuur' naar verwachting veel eenvoudiger te realiseren zal zijn.

In tabel 7.10 wordt een overzicht gegeven van de verwachte instroom voor de opleidingstypen waarvoor een goed tot zeer goed perspectief verwacht wordt, maar waarvoor de conjunctuurgevoeligheid groot is. Dit overzicht wordt beperkt tot de opleidingen op MBOniveau. Bij sommige opleidingen zijn de arbeidsmarktperspectieven voor VBO'ers weliswaar niet ongunstig, maar dit is voor een belangrijk deel het gevolg van de vervangingsvraag vanwege de hoge arbeidsmarktuitstroom van laag geschoolden op relatief jonge leeftijd. Een uitbreiding van de capaciteit in het VBO-onderwijs is echter vanuit het oogpunt van de macrodoelmatigheid van het onderwijs minder zinvol. Alleen door alsnog via de beroepsopleidende of beroepsbegeleidende leerweg een startkwalificatie op MBO-niveau te behalen kunnen schoolverlaters voorkomen in een dergelijke fuik van 'dead end jobs' terecht te komen. Met andere woorden: de macrodoelmatigheid van het beroepsonderwijs is sterk gebaat bij een optimaal aanbod van leerwegen die het voor veel VBO'ers mogelijk maken een startkwalificatie op de arbeidsmarkt te behalen. Aangenomen mag worden dat degenen die daar de meeste moeite mee hebben, het meest gebaat zijn bij een toereikende capaciteit voor de beroepsbegeleidende leerwegen die het meest aansluiten bij de meer praktische orientatie van veel van deze schoolverlaters. Een toename van het aantal leerplaatsen dat bij bedrijven beschikbaar is, is hierbij van groot belang. 
Tabel 7.10

Verwachte instroom 1997- 2002 voor de opleidingstypen met een goed perspectief maar met hoge conjunctuurgevoeligheid, Limburg (als percentage van de werkgelegenheid)

Opleidingstype

BOL/BBL laboratorium

BOL/BBL secretariaat

$\mathrm{BOL}$ openbare orde en veiligheid

BOL/BBL werktuigbouw en mechanische techniek

BOL/BBL bouw

BOL/BBL motorvoertuigentechniek

BOL/BBL elektrotechniek

BOL/BBL procestechniek

BOL/BBL grond-, weg- en waterbouw

BOL/BBL installatietechniek

BOL/BBL fijnmechanische techniek

BOL/BBL vliegtuigtechniek

BOL/BBL operationele techniek

$\mathrm{BOL} / \mathrm{BBL}$ grafische techniek

$B O L$ verzekeringswezen

BOLBBL vervoer instroom typering

\begin{tabular}{|c|c|}
\hline . & hoog \\
\hline 14 & gemiddeld \\
\hline 11 & gemiddeld \\
\hline 10 & laag \\
\hline 9 & laag \\
\hline 9 & laag \\
\hline 8 & laag \\
\hline 3 & laag \\
\hline . & laag \\
\hline . & laag \\
\hline 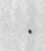 & laag \\
\hline . & laag \\
\hline * & laag \\
\hline . & laag \\
\hline . & laag \\
\hline 2 & erg laag \\
\hline
\end{tabular}

Bron: $R O A$

Uit de tabel blijkt dat voor de opleidingsrichting BOL/BBL laboratorium de instroom naar verwachting hoog zal zijn. Dit betekent dat een eventuele capaciteitsuitbreiding naar verwachting behoorlijke inspanningen zal vragen. Voor de technische opleidingen op MBOniveau is de instroom over het algemeen veel te laag om aan de vraag te kunnnen voldoen. Een vergroting van de populariteit van de technische opleidingen - gekoppeld aan een eventuele uitbreiding van de capaciteit - kan een zeer effectief middel zijn om de macrodoelmatigheid van het onderwijs in Limburg te vergroten. De conjuncturele ontwikkclingen dienen hierbij echter zorgvuldig in het oog te worden gehouden, gezien de gevoeligheid van de vraag naar schoolverlaters met een technische achtergrond voor schommelingen in de conjunctuur. Bovendien kan er op termijn in het onderwijs een belangrijk knelpunt ontstaan in de vorm van een tekort aan leraren in de techniek.

Zoals reeds eerder gesteld nemen de verzorgende en medische opleidingen op MBO-niveau een bijzondere positie in. Het arbeidsmarktperspectief voor deze opleidingstypen is goed tot zeer goed, maar kwetsbaar gezien de afhankelijkheid van het overheidsbeleid en de geringe uitwijkmogelijkheden op de arbeidsmarkt. De instroom van schoolverlaters met een verzorgende of medische opleiding op de arbeidsmarkt zal naar verwachting laag zijn. Dit impliceert dat een vergroting van de instroom in de verplegende en verzorgende opleidingen derhalve ook hier de macrodoelmatigheid van het onderwijs kan bevorderen. Wel dienen hierbij met name de ontwikkelingen in het overheidsbeleid zorgvuldig in het oog gehouden te worden. Bovendien bestaat er in de opleiding een belangrijk knelpunt in de vorm van een tekortschietend aantal BPV-plaatsen. 


\section{Uitgelicht: BOLBBL Procestechniek}

Aan de hand van de verwachte ontwikkelingen aan de vraag- en aanbodzijde van de arbeidsmarkt kan een indicatie gegeven worden van de te verwachten toekomstige arbeidsmarktperspectieven op de middellange termijn voor nieuwkomers op de arbeidsmarkt. Dit arbeidsmarktperspectief geeft aan wat de mogelijkheden zijn voor nieuwkomers om een baan te vinden die op grond van de opleidingsachtergrond als passend kan worden beschouwd. Aan de vraagzijde wordt een onderscheid gemaakt tussen uitbreidings- en vervangingsvraag. Tezamen vormen deze het aantal baanopeningen voor nieuwkomers. Voor de opleiding BOL/BBL Procestechniek wordt in de periode 1997-2002 in Limburg een uitbreidingsvraag van $25 \%$ van de huidige werkgelegenheid voor dit opleidingstype verwacht (tabel 4.4 van de Statistische Bijlage). Dit percentage wordt als 'hoog' getypeerd, hetgeen duidt op een snel groeiende vraag naar arbeidskrachten met een procestechnische opleiding op MBO-niveau. De vervangingsvraag zal gedurende de periode 1997-2002 naar verwachting 14\% bedragen, hetgeen als 'laag' wordt getypeerd (tabel 4.5). Daaruit resulteert dus een percentage baanopeningen dat $39 \%$ (dit is bijna 1400 in absolute aantallen) bedraagt (tabel 4.6) en als 'gemiddeld' wordt getypeerd. Tegenover de verwachte ontwikkelingen aan de vraagzijde staan de stromen aan de aanbodzijde van de arbeidsmarkt, i.c de arbeidsmarktinstroom. Deze bedraagt over de periode 1997-2002 3\% en is 'laag' te noemen, zeker in verhouding tot de omvang van de vraag (tabel 4.7). Dit betekent dat voor degenen die vanuit de opleiding BOL/BBL Procestechniek op de arbeidsmarkt instromen het arbeidsmarktperspectief zeer goed is; de waarde van de Indicator Toekomstige Arbeidsmarktperspectieven bedraagt 0,74 (tabel 4.8).

Het arbeidsmarktperspectief wordt voor een belangrijk deel bepaald door de verwachte economische ontwikkeling. Het zeer goede perspectief voor de opleiding BOL/BBL Procestechniek kan daarbij het gevolg zijn van een structureel sterke positie op de arbeidsmarkt. Het kan echter ook voornamelijk conjunctureel van aard zijn. Dit is niet geheel onwaarschijnlijk, daar algemeen gesteld de arbeidsmarktkansen voor schoolverlaters van technische opleidingen in aanzienlijke mate bepaald worden door de werkgelegenheidsontwikkelingen in de conjunctuurgevoelige industriële bedrijfssectoren. De meer structurele positie van de opleiding BOLBBBL Procestechniek kan met behulp van de conjunctuurgevoeligheid van de werkgelegenheid bepaald worden. Voor een nadere definitie van dit begrip zij verwezen naar de Verklarende woordenlijst achterin dit rapport. Voor de opleiding BOL/BBL Procestechniek bedraagt de conjunctuurgevoeligheid 0,84 (tabel 4.9) en dit kan als 'gemiddeld' worden getypeerd.

De risico's op de arbeidsmarkt beperken zich niet tot de conjunctuurgerelateerde fluctuaties in de werkgelegenheid. Ook de mate waarin schoolverlaters afhankelijk zijn van de werkgelegenheidsperspectieven in een beperkt aantal beroepsgroepen is een belangrijke risicofactor. Dit wordt uitgedrukt in de spreidingsindex, die voor de opleiding BOL/BBL Procestechnick 3,71 bedraagt (tabel 4.9). Hiermee wordt aangegeven dat voor deze opleiding de uitwijkmogelijkheden naar andere beroepsgroepen gering zijn. Samenvattend lijken dus de arbeidsmarktrisico's van de opleiding BOL/BBL Procestechniek niet onaanzienlijk te zijn. Veranderingen in het curriculum, waardoor de opleiding wordt verbreed en daardoor toegang verschaft tot een breder beroependomein, kan deze kwetsbaarheid verminderen. Wel dient bedacht te worden dat een dergelijke verbreding niet slechts voor- 
delen biedt. Wanneer er sprake is van veel uitwijkmogelijkheden impliceert dit immers ook dat de schoolverlaters meer concurrentie ondervinden van andere opleidingstypen. Bovendien kan het ten koste gaan van de specialisatie, waardoor de productiviteit, c.q. de directe inzetbaarheid van de schoolverlaters geringer wordt. Dit kan er zelfs toe leiden dat ze naar de secundaire arbeidsmarkt verdrongen worden.

\subsection{Aandachtspunten voor het onderwijsbeleid}

Vanuit het oogpunt van de zogenaamde macrodoelmatigheid van het onderwijs is het wenselijk de instroom van leerlingen in opleidingen met goede of zeer goede arbeidsmarktperspectieven te bevorderen. Het zonder meer vergroten van het onderwijsaanbod zal echter niet altijd de gewenste effecten sorteren. Een vergroting van de opleidingscapaciteit garandeert immers niet dat deze capaciteit ook daadwerkelijk benut zal worden. Een betere geografische spreiding of de introductie van een opleidingsvariant die op dat moment nog niet wordt aangeboden, zal doorgaans wel de leerlingeninstroom voor het betreffende opleidingstype verhogen, doordat mobiliteitsdrempels worden weggenomen of beter ingespeeld kan worden op de interesse of capaciteiten van leerlingen.

Een vraag die zich voordoet bij een dergelijke uitbreiding van het onderwijsaanbod is echter welke leerlingen hiermee worden aangetrokken. Als een verbeterde geografische spreiding er alleen toe leidt dat leerlingen dezelfde opleiding minder ver van huis kunnen volgen, of als de extra belangstelling voor een nieuwe opleiding met goede perspectieven leerlingen trekt die anders een andere opleiding met zeer goede perspectieven hadden gekozen, dan is de macrodoelmatigheid van de nieuwe opleiding ondanks de gunstige arbeidsmarktperspectieven beperkt. Nieuw aanbod van opleidingen zal daarom met name een zinvol effect sorteren, wanneer er leerlingen worden aangetrokken die anders een opleiding hadden gekozen met duidelijk slechtere perspectieven.

De omvang van de verwachte instroom op de arbeidsmarkt vormt een indicatie voor de mogelijkheden die een capaciteitsvergroting biedt. Zoals hierboven reeds werd opgemerkt, dient een capaciteitsvergroting ter vergroting van de macrodoelmatigheid gepaard te gaan met het aantrekken van de 'juiste' doelgroep. Dit kan betekenen dat een andere opleiding wordı gekozen of dat wordt doorgestroomd naar een meer perspectiefrijke opleiding. Bovendien dient er voldoende 'infrastructuur' in de regio aanwezig te zijn om de toegenomen leerlingenstroom een adequate voorbereiding op de arbeidsmarkt te kunnen bieden. Hierbij gaat het niet alleen om het onderwijs zelf, maar bijvoorbeeld ook om het aantal leerplaatsen bij bedrijuen.

Wanneer de verwachte instroom reeds relatief hoog is dan vindt het goede perspectiel vooral zijn oorsprong in de grote vraag naar nieuwkomers met het betreffende opleidingstype. De opleiding is dan reeds relatief populair in verhouding tot de 'omvang' van de markt voor deze opleiding in Limburg. Dit impliceert dat omzetten van een eventuele capaciteitsvergroting in een daadwerkelijke vergroting van de instroom aanzienlijke inspanningen zal vragen, zoals het verder vergroten van het aantal leerplaatsen bij bedrijven en het aanboren van geheel nieuwe groepen leerlingen. Wanneer daarentegen de verwachte instroom relatief klein is, dan ligt vooral de geringe instroom aan het goede perspectief ten grondslag. In dat geval zal het omzetten van een eventuele capaciteitsvergroting in een daadwerkelijke 
vergroting van de instroom waarschijnlijker eenvoudiger te realiseren zijn. Het marktaandeel van deze opleiding is dan waarschijnlijk laag. Door bijvoorbeeld de doorstroom uit de lagere opleidingen - met een slechter perspectief - te bevorderen kan het marktaandeel vergroot worden. Ook het realiseren van de gewenste infrastructuur in de regio zal waarschijnlijk eenvoudiger zijn, hoewel in specifieke segmenten van de arbeidsmarkt natuurlijk specifieke problemen een verdere capaciteitsvergroting kunnen belemmeren. Voorbeelden hiervan zijn de technische en de medische opleidingen. Bij de technische opleidingen kan er op termijn in het onderwijs een belangrijk knelpunt ontstaan in de vorm van een tekort aan leraren in de techniek. In het medisch onderwijs vormt het tekortschietend aantal BPVplaatsen een belangrijk knelpunt.

Naast het arbeidsmarktperspectief, dat gebaseerd is op de verwachte ontwikkelingen in vraag en aanbod, kan het onderwijsbeleid ook de structurele positie van opleidingen als richtlijn nemen. Een tweetal risico-indicatoren is op dit punt van belang: de conjunctuurgevoeligheid van de werkgelegenheid en de uitwijkmogelijkheden naar andere beroepsgroepen. Zo zijn er bepaalde opleidingen die een hoge mate van conjunctuurgevoeligheid combineren met beperkte uitwijkmogelijkheden. Veranderingen in het onderwijs, waardoor de opleiding wordt verbreed en waardoor toegang wordt verkregen tot een breder beroependomein, kunnen deze kwetsbaarheid verminderen. Omgekeerd kunnen ontwikkelingen aan de vraagkant van de arbeidsmarkt leiden tot een behoefte aan personeel met zeer specifieke vaardigheden. Hierdoor kan het wenselijk zijn een meer specialistische opleiding te starten. Hierbij dient altijd wel overwogen te worden in hoeverre de vraag naar deze vakspecialisten stabiel is, omdat de voordelen van het specialisme op moeten wegen tegen de arbeidsmarktrisico's die een dergelijke specialisatie met zich meebrengt.

De volgende opleidingstypen hebben een structureel sterke positie op de Limburgse arbeidsmarkt: $B O L / B B L$ landbouw en veeteelt, $B O L / B B L$ milieu en groene ruimte, $B O L / B B L$ brood en banket, BOL/BBL levensmiddelentechniek, BOL/BBL horeca, BOL/BBL administratie, $B O L / B B L$ handel, BOL/BBL bedrijfskunde, BOL/BBL geld, bank en belastingen en $B O L / B B L$ automatisering. Met name voor een groot aantal de opleidingen op MBO-niveau gericht op de industriële sectoren en de bouwsector is het perspectief goed, maar is de positie kwetsbaar als gevolg van de hoge conjunctuurgevoeligheid van de werkgelegenheid.

Vanwege de over het algemeen relatief lage verwachte instroom in de opleidingen met een goed perspectiel, kan een vergroting van de populariteit van deze opleidingen - gekoppeld aan een eventuele uitbreiding van de capaciteit - een zeer effectief middel zijn om de macrodoelmatigheid van het onderwijs in Limburg te vergroten. Uitzonderingen vormen de 'groene' opleidingen en de laboratoriumopleiding die gekenmerkt worden door een relatief grote arbeidsmarktinstroom van schoolverlaters. Indien de conjunctuurgevoeligheid van de werkgelegenheid voor een bepaald opleidingstype groot is, dienen de conjuncturele ontwikkelingen hierbij echter zorgvuldig in het oog gehouden te worden, gezien de gevoeligheid van de vraag naar met name schoolverlaters met een technische achtergrond voor schommelingen in de conjunctuur.

Een bijzondere positie nemen de verzorgende en medische opleidingen op MBO-niveau in. Het arbeidsmarktperspectief voor deze opleidingstypen is goed tot zeer goed. Bovendien is de conjunctuurgevoeligheid van de werkgelegenheid laag. Gezien de relatief lage verwachte 
instroom kan een vergroting van de populariteit van deze opleidingen de macrodoelmatigheid van het onderwijs in Limburg bevorderen. Twee factoren maken de arbeidsmarktpositie van de schoolverlaters van deze opleidingstypen echter kwetsbaar. In de eerste plaats is de omvang van de vraag in aanzienlijke mate afhankelijk van het overheidsbeleid. In de tweede plaats zijn de arbeidskrachten met een medische of verzorgende opleidingsachtergrond beperkt inzetbaar; de uitwijkmogelijkheden op de arbeidsmarkt zijn over het algemeen gering.

De opleidingstypen MAVO, VBO horeca en levensmiddelentechniek, VBO administratie, handel en textiel, VBO verzorging, HAVO/VWO en BOL sociaal-cultureel kennen een slecht perspectief. De brede inzetbaarheid van de schoolverlaters van deze opleidingen biedt echter misschien mogelijkheden elders op de arbeidsmarkt een plek te vinden. Met name de VBO'ers en AVO'ers zullen dan echter vaak terecht komen op de secundaire arbeidsmarkt. Een structureel zwakke positie op de arbeidsmarkt hebben de opleidingstypen VBO vervoer, VBO motorvoertuigentechniek, VBO grafische techniek en BOL/BBL toerisme en recreatie.

De macrodoelmatigheid van het beroepsonderwijs is al met al het meest gebaat bij een adequaat aanbod van leerwegen die VBO schoolverlaters in staat stellen een kwalificatie op MBO-niveau te behalen. Dit geldt het sterkst voor de vervoers-, motorvoertuigentechniek, grafische techniek-, administratie, handel en horeca-opleidingen. Vanzelfsprekend geldt dit ook voor de opleidingen die ongeschoolden met slechts Basisonderwijs, MAVO'ers en HAVO-VWO'ers in staat stellen met succes een beroepsopleiding te volgen met goede arbeidsmarktperspectieven en geringe arbeidsmarktrisico's. Ook opleidingen die een verschuiving van de schoolkeuze van het te populaire opleidingstype BOLBBL toerisme en recreatie naar administratief-economische opleidingen met een betere arbeidsmarkipositie bewerkstelligen, kunnen een belangrijke bijdrage leveren aan het vergroten van de macrodoelmatigheid van het onderwijs in Limburg. 


\section{Verklarende woordenlijst}

\section{Arbeidsmarktkrapte}

Het begrip arbeidsmarktkrapte dat in deze rapportage gehanteerd wordt, is gedefinieerd als de verhouding tussen het aantal openstaande vacatures en het aantal werkzoekenden in bemiddelingsfase 1 naar beroepsgroep of opleidingstype. Wanneer de indicator voor de arbeidsmarktkrapte kleiner is dan één, is er sprake van een aanbodoverschot op hel betreffende arbeidsmarktsegment. Wanneer de indicator voor de arbeidsmarktkrapte groter is dan één, is er sprake van een tekort aan werkzoekenden in het betreffende segment. Dit tekort kan twee oorzaken hebben: wanneer het aanbod getalsmatig tekortschiet is er sprake van een kwantitatief probleem. De knelpuntsindicator (zie hier beneden) zal dan groter zijn dan één. Wanneer het probleem vooral gelegen is in het feit dat het percentage werkzoekenden in fase 1 laag is, is dit tekort vooral een kwalitatief aansluitingsprobleem dat zich zal manifesteren in een knelpuntsindicator kleiner dan één. Aangezien werkzoekenden niet naar bedrijfssector ingedeeld kunnen worden, kan deze maatstaf niet gebruikt worden om de arbeidsmarktkrapte naar bedrijfssector te berekenen. De arbeidsmarktkrapte naar bedrijfssector is daarom gedefinieerd als het gewogen gemiddelde van de arbeidsmarktkrapte naar beroepsgroep. De wegingsfactor is daarbij gebaseerd op het aandeel van de betreffende beroepsgroep in het totale aantal vacatures in die bedrijfssector. Hoe hoger de arbeidsmarktkrapte in een bedrijfssector, hoe groter de rekruteringsproblemen.

\section{Baanopeningen}

De totale vraag naar nieuwkomers op de arbeidsmarkt, zoals deze is bepaald door de werkgelegenheidsgroei (positieve uitbreidingsvraag) en de vervangingsvraag.

\section{Bedrijfsklasse}

Alle voorkomende bedrijven zijn ingedeeld in een aantal clusters. De totale werkgelegenheidscijfers zijn in deze rapportage verbijzonderd naar 33 bedrijfsklassen.

\section{Bedrijfssector}

Alle voorkomende bedrijven zijn ingedeeld in een aantal clusters. De in deze rapportage gepresenteerde informatie is - met uitzondering van de totale werkgelegenheid - verbijzonderd naar 13 bedrijfssectoren. Deze komen overeen met de door het CPB gehanteerde bedrijfssectorindeling.

\section{Bemiddelingsfase}

Het begrip bemiddelingsfase dat in deze rapportage wordt gehanteerd, is gebaseerd op de indeling zoals dat door Arbeidsvoorziening in het Primair Gemeenschappelijk Informatiesysteem wordt gehanteerd. Arbeidsvoorziening classificeert hierbij de werkzoekenden naar bemiddelbaarheid; wanneer de kwalificatie 'fase I' aan een werkzoekende wordt toegekend, is deze in principe direct bemiddelbaar. Wanneer een werkzockende in een hogere bemiddelingsfase wordt ingedeeld, impliceert dit een grotere afstand tot de arbeidsmarkt. 


\section{Beroepsgroep}

Alle voorkomende beroepen zijn ingedeeld in een aantal clusters. In deze rapportage wordt hoofdzakelijk uitgegaan van 127 beroepsgroepen, gebaseerd op de SBC (3-digit) van het CBS.

\section{Beroepssector}

Alle voorkomende beroepen zijn ingedeeld in een aantal clusters. Zo worden in hoofdstuk 1 elf beroepssectoren onderscheiden.

\section{Beroepssegment}

Alle voorkomende beroepen zijn ingedeeld in een aantal clusters. In deze rapportage wordt hoofdzakelijk uitgegaan van 127 beroepsgroepen. In een aantal gevallen wordt echter een indeling naar 43 beroepssegmenten gehanteerd, gebaseerd op de SBC (2-digit) van het CBS

\section{Bijscholing}

Er is sprake van bijscholing wanneer een scholingstraject de opleidingsachtergrond van een werkzoekende niet verandert.

\section{Bijscholingspotentieel in verhouding tot de scholingsbehoefte}

Het bijscholingspotentieel (in kwantitatieve zin) wordt gevormd door de niet-werkende werkzoekenden in fase 2 en 3 . Het bijscholingspotentieel in verhouding tot de scholingsbehoefte - het verschil tussen de som van de openstaande vacatures en de verwachte baanopeningen enerzijds en de direct inzetbare werkzoekenden (de schoolverlaters en de nietwerkende werkzoekenden in fase 1) anderzijds - geeft aan in hoeverre werkzoekenden door middel van bijscholing hun arbeidsmarktkansen kunnen vergroten. Hoe groter deze verhouding is, hoe groter de mogelijkheden voor de werkzoekenden zijn. Wanneer de bijscholingsbehoefte gering is, zijn de kansen om via bijscholing de arbeidsmarktkansen te vergroten eveneens gering.

\section{Bruto maandloon}

Het bruto maandloon is vastgesteld op basis van een voltijdsaanstelling.

\section{Conjunctuurgevoeligheid}

De conjunctuurgevoeligheid van de werkgelegenheid heeft betrekking op de mate waarin de werkgelegenheid voor mensen met een bepaalde opleidingsachtergrond gevoelig is voor veranderingen van de economische situatie. Deze indicator geeft daarmee de mate van werkzekerheid aan. De conjunctuurgevoeligheid wordı bepaald door de sectorale werkgelegenheidsfluctuaties in het verleden te relateren aan de mate waarin een opleidingstype momenteel in de verschillende bedrijfssectoren is vertegenwoordigd. Hierbij wordt rekening gehouden met het feit dat niet ieder opleidingstype even sterk meefluctueert met de werkgelegenheidsschommelingen van de bedrijfssector.

\section{Deeltijdarbeid}

Deeltijdarbeid betreft personen die hoogstens 32 uur maar minstens 12 uur per week werkzaam zijn. 


\section{Werkzaam buiten eigen vakrichting}

Een indicatie van de mate waarin arbeidskrachten werkzaam zijn in een functie die niet goed aansluit bij de gevolge opleidingsrichting. De mate waarin schoolverlaters buiten de eigen vakrichting werkzaam zijn wordt in dit rapport vastgesteld door de schoolverlaters zelf te laten aangeven in hoeverre voor de door hen uitgeoefende functie de eigen of een verwante opleidingsrichting vereist is.

\section{Flexibel werk}

Van flexibel werk is sprake bij uitzendkrachten, oproepkrachten, invalkrachten, contracten zonder een vast aantal arbeidsuren en indien geen vast dienstverband is overeengekomen.

\section{Jongere}

Een jongere is tussen de 15 en de 29 jaar oud.

\section{Knelpuntsindicator}

Het begrip knelpuntsindicator dat in deze rapportage wordt gehanteerd is gedefinieerd als de verhouding tussen het aantal vacatures dat niet door werkzoekenden in bemiddelingsfase 1 vervuld kan worden en het aantal werkzoekenden in bemiddelingsfase 2 en 3 . Hoe hoger de knelpuntsindicator, hoe minder werkzoekenden met een grotere afstand tot de arbeidsmarkt er beschikbaar zijn voor de vacatures die niet door direct bemiddelbare werkzoekenden vervuld kunnen worden. Dit impliceert tevens dat een hoge knelpuntsindicator een werkzoekende in het betreffende segment de mogelijkheid biedt via bijscholing de kansen op een baan te vergroten. Wanneer het aantal werkzoekenden in fase 1 het aantal vacatures overtreft, is de knelpuntsindicator gelijk aan 0 . Er is dan geen sprake van cen tekort aan gekwalificeerd aanbod. Het aantal banen schiet juist tekort om alle direct inzetbare werkzoekenden aan werk te helpen.

\section{Langdurig werkzoekende}

Het begrip langdurig werkzoekende dat in deze rapportage wordt gehanteerd, is gedefinieerd als een werkzoekende die langer dan een jaar ingeschreven is bij Arbeidsvoorziening. Opgemerkt dient te worden dat dit niet noodzakelijkerwijs impliceert dat de betreffende werkzoekende tijdens de periode niet gewerkt heeft.

\section{Langdurig openstaande vacature}

Het begrip langdurig openstaande vacature dat in deze rapportage wordı gehanteerd, is gedefinieerd als een vacature die langer dan drie maanden openstaat.

\section{Omscholing}

Er is sprake van omscholing wanneer het scholingstraject de opleidingsachtergrond van een werkzoekende verandert. Omscholing kan zowel niveauverhogend als richtingveranderend van aard zijn.

\section{Onderbenutting}

Een indicatie van de mate waarin arbeidskrachten werkzaam zijn op een functieniveau dat lager is dan hun opleidingsniveau. De onderbenutting van schoolverlaters wordt in dit rapport vastgesteld door de schoolverlaters zelf te laten aangeven welk opleidingsniveau vereist is voor de door hen uitgeoefende functie. 


\section{Opleidingssector}

Alle voorkomende opleidingen zijn samengevoegd tot een aantal clusters. In deze rapportage wordt voornamelijk uitgegaan van 113 opleidingstypen. In een aantal gevallen wordt echter een indeling naar 26 opleidingssectoren gehanteerd.

\section{Opleidingstype}

Alle voorkomende opleidingen zijn samengevoegd tot een aantal clusters. In deze rapportage wordt voornamelijk uítgegaan van 113 opleidingstypen. De naamgeving van de opleidingenclassificatie is aangepast aan de nieuwe kwalificatiestructuur zoals die is vastgelegd in de WEB. In het onderstaande overzicht wordt een relatie gelegd tussen de oude opleidingsstructuur en de bijbehorende benamingen en de nieuwe kwalificatiestructuur.

\begin{tabular}{|c|c|c|c|c|}
\hline niveau & $\begin{array}{l}\text { nieuwe } \\
\text { opleidingsaanduiding } \\
\text { alle sectoren } \\
\text { behalve agrarisch }\end{array}$ & $\begin{array}{l}\text { opleidingsaanduiding } \\
\text { in de agrarische } \\
\text { sector }\end{array}$ & $\begin{array}{l}\text { oude } \\
\text { opleidingsaanduiding }\end{array}$ & duur \\
\hline 1 & assistentenopleiding & $\begin{array}{l}\text { assisterend } \\
\text { beroepsbeoefenaar }\end{array}$ & & 0,5-1 jaar \\
\hline 2 & basisberoepsopleiding & $\begin{array}{l}\text { beginnend } \\
\text { beroepsbeoefenaar }\end{array}$ & $\begin{array}{l}\text { MBO-kort } \\
\text { Leerlingwezen-primair }\end{array}$ & 2-3 jaar \\
\hline 3 & vakopleiding & $\begin{array}{l}\text { zelfstandig } \\
\text { beroepsbeoefenaar }\end{array}$ & $\begin{array}{l}\text { MBO-tussen } \\
\text { MBO-lang } \\
\text { Leerlingwezen-secundair }\end{array}$ & 2-4 jaar \\
\hline 4 & middenkaderopleiding & kaderfunctionaris & $\begin{array}{l}\text { MBO-lang } \\
\text { Leerlingwezen-tertiair }\end{array}$ & 3-4 jaar \\
\hline 4 & specialistenopleiding & $\begin{array}{l}\text { gespecialiseerd } \\
\text { beroepsbeoefenaar }\end{array}$ & Leerlingwezen-tertiair & 1-2 jaar \\
\hline
\end{tabular}

\section{Oudere}

Een oudere is tussen de 50 en de 64 jaar oud.

\section{Potentiële beroepsbevolking}

De potentiële beroepsbevolking omvat de werkenden, de werkzoekenden zonder baan en de niet-participerenden. ledereen met een leeftijd tussen de 15 en de 64 jaar en die geen voltijdsopleiding volgt wordt tot de potentiële beroepsbevolking gerekend. Als men meer dan 12 uur per week werkt, wordı men tot de werkzame beroepsbevolking gerekend. Werkt men niet of minder dan 12 uur, maar wil men wel minstens 12 uur per week betaalde arbeid verrichten, dan behoort men tot de werkloze beroepsbevolking. Werkt men niet of minder dan 12 uur, en is men niet op zoek naar betaalde arbeid voor minstens 12 uur per week, dan behoort men tot de niet-participerende beroepsbevolking. 


\section{Scholingsbehoefte}

Wanneer er op de korte termijn knelpunten in de personeelsvoorziening verwacht worden, kan bij- en omscholing van werkzoekenden een instrument zijn om op deze knelpunten te anticiperen. De scholingsbehoefte vanuit de vraagzijde van de arbeidsmarkt is gedefinieerd als het verschil tussen de som van de openstaande vacatures en de verwachte baanopeningen enerzijds en de direct inzetbare werkzoekenden - de schoolverlaters en de nietwerkende werkzoekenden in fase 1 - anderzijds. Naarmate dit verschil groter is, is de scholingsbehoefte groter. Wanneer er weinig tot geen knelpunten zijn, is het aantal baanopeningen en openstaande vacatures kleiner dan het aantal direct inzetbare werkzoekenden; de scholingsbehoefte is dan gering.

\section{Toekomstig arbeidsmarktperspectief}

Het toekomstig arbeidsmarktperspectief geeft de verhouding tussen aanbod en vraag in de prognoseperiode voor een opleidingstype weer. Als het arbeidsmarktperspectief slecht is, betekent dit dat er in het (de) komende ja(a)r(en) veel meer aanbod van nieuwkomers is dan er baanopeningen zijn. Hierdoor zal de arbeidsmarktpositie gaan verslechteren. Deze verslechtering kan een hogere werkloosheid betekenen, maar door aanpassingsprocessen op de arbeidsmarkt kan dit ook leiden tot het moeten aanvaarden van banen op een lager niveau, een lagere beloning en meer tijdelijke contracten. Omgekeerd zal een goed perspectief tot een grotere kans op werk, maar ook tot een verbeterde positie op andere punten leiden. Het toekomstig arbeidsmarktperspectief per opleidingstype word bepaald door middel van de indicator toekomstige arbeidsmarktsituatie (ITA), die is gedefinieerd als de verhouding tussen enerzijds de verwachte instroom van schoolverlaters en het aantal direct bemiddelbare werkzoekenden en anderzijds de verwachte baanopeningen. Naarmate de waarde van de indicator hoger wordt, wordt het perspectief slechter. Analoog geeft de indicator toekomstige arbeidsmarktsituatie naar beroep (ITAB) het arbeidsmarktperspectief naar beroepsgroep weer. Merk overigens op dat een hogere ITA of ITAB een slechtere (toekomstige) arbeidsmarktsituatie impliceert, terwijl een hogere arbeidsmarktkrapte een indicatie is voor een betere (huidige) arbeidsmarktpositie van een opleidingstype.

\section{Toekomstige knelpunten in de personeelsvoorziening}

Als de toekomstige vraag naar werkenden met een bepaalde opleidingsachtergrond groter is dan het aanbod, kunnen knelpunten in de personeelsvoorziening verwach worden. Vergelijkbaar met de indicator toekomstige arbeidsmarktsituatie (ITA of ITAB, zic hierboven) geeft de indicator toekomstige knelpunten in de personeelsvoorziening naar beroep (ITKB) deze vraag-aanbod-spanning aan. Het verschil met de ITAB is dat bij de ITKB de uitstroom van werkenden als gevolg van een krimpende werkgelegenheid is mecgerekend in de vraag, omdat verwacht mag worden dat bij knelpunten in de personeelsvoorziening deze (gedwongen) uitstroom kan worden afgeremd of elders werk zou kunnen vinden. Naarmate de waarde van de indicator lager wordt, zijn de verwachte knelpunten groter. Analoog geeft de indicator toekomstige knelpunten in de personeelsvoorziening (ITKP) de knelpunten naar opleidingstype weer.

\section{Uitbreidingsvraag}

De vraag naar nieuwe arbeidskrachten die ontstaat door groei van de werkgelegenheid. Als er sprake is van een werkgelegenheidsdaling, is de uitbreidingsvraag negatief. 


\section{Uitwijkmogelijkheden}

De mate waarin arbeidskrachten met een bepaalde opleidingsachtergrond terecht kunnen komen in andere beroepsgroepen op een aansluitend of hoger functie-niveau. Deze maatstaf geeft daarmee aan in hoeverre arbeidskrachten afhankelijk zijn van de arbeidsmarktsituatie in een bepaald beroep. De uitwijkmogelijkheden worden bepaald met behulp van een spreidingsindex. Deze index geeft een indicatie van het aantal beroepsgroepen waarnaar men kan uitwijken.

\section{Vacature}

Het begrip vacature is in deze rapportage gebaseerd op de door het CBS gehanteerde definitie van een 'openstaande vacature'.

\section{Vacaturegraad}

Het aantal openstaande vacatures per 1.000 werkenden in een bedrijfssector, beroepsgroep of opleidingstype.

\section{Vervangingsvraag}

De vraag naar nieuwe arbeidskrachten die ontstaat doordat de arbeidsplaatsen van werkenden die met pensioen gaan, arbeidsongeschikt worden of zich (tijdelijk) terugtrekken van de arbeidsmarkt opnieuw moeten worden opgevuld. De vervangingsvraag per beroepsgroep kan bovendien ontstaan door de beroepsmobiliteit. Vertrek van werkenden dat niet leidt tot vraag naar nieuwkomers uit hetzelfde opleidingstype of beroepsgroep wordt niet meegerekend als vervangingsvraag.

\section{Werkzoekende}

Het begrip werkzoekende is in deze rapportage gedefinieerd als de bij Arbeidsvoorziening ingeschreven niet-werkende werkzoekenden.

\section{Zelfstandige}

Het begrip zelfstandig bevat ook personen die werkzaam zijn in het bedrijf of de praktijk van hun partner of ouders en free-lancers e.d. 
